\title{
Mari Toivanen
}

\section{The Kobane \\ Generation}

\section{Kurdish Diaspora Mobilising in France}

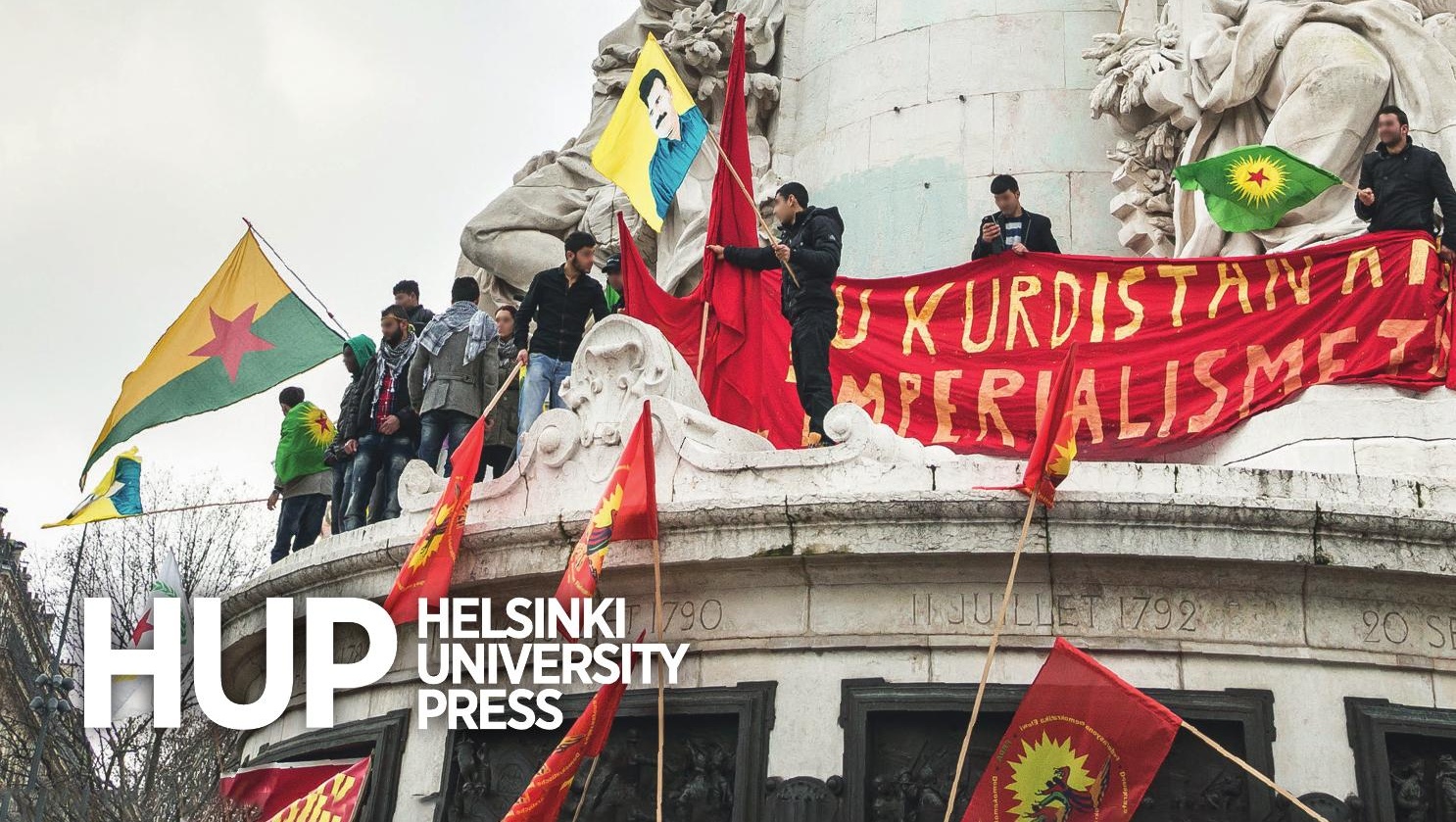


Mari Toivanen

\section{The Kobane Generation}

Kurdish Diaspora Mobilising in France 


\author{
Published by \\ Helsinki University Press \\ www.hup.fi \\ (C) Mari Toivanen 2021 \\ First published in 2021
}

Cover design by Ville Karppanen

Cover photo by Huang Zheng / Shutterstock.com. Paris, France.

11 January 2014. Kurdish people on the Place de la République, demonstrating for truth and justice in the affair of the assassination of three Kurdish activists on 9 January 2013.

Print and digital versions typeset by Siliconchips Services Ltd.

$$
\begin{aligned}
& \text { ISBN (Paperback): 978-952-369-042-4 } \\
& \text { ISBN (PDF): 978-952-369-043-1 } \\
& \text { ISBN (EPUB): 978-952-369-044-8 } \\
& \text { ISBN (Mobi): 978-952-369-045-5 }
\end{aligned}
$$

DOI: https://doi.org/10.33134/HUP-11

This work is licensed under the Creative Commons Attribution NonCommercial 4.0 International (CC BY-NC 4.0) License (unless stated otherwise within the content of the work). To view a copy of this license, visit https://creativecommons.org/licenses/by-nc/4.0/ or send a letter to Creative Commons, 444 Castro Street, Suite 900, Mountain View, California, 94041, USA. This license allows sharing and copying any part of the work providing author attribution is clearly stated. Under this license, the user of the material must indicate if they have modified the material and retain an indication of previous modifications. This license prohibits commercial use of the material.

The full text of this book has been peer reviewed to ensure high academic standards. For full review policies, see http://www.hup.fi/

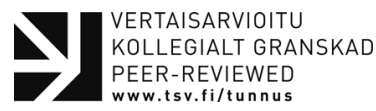

Suggested citation:

Toivanen, M. (2021). The Kobane Generation. Kurdish Diaspora Mobilising in France. Helsinki: Helsinki University Press. https://doi.org/10.33134/HUP-11.

To read the free, open access version of this book online, visit https://doi.org/10.33134/HUP-11 or scan this QR code with your mobile device: 


\section{Table of Contents}

List of tables, illustrations and map $\quad \mathrm{V}$

Abbreviations vii

Acknowledgements $\quad$ ix

Part I: Background 1

Chapter 1: When Kobane Happened 3

1.1. Kobane Momentum 3

1.2. Kurdish Mobilisation in France 6

1.3. Diasporas as Non-state Actors: From Mobilisation to Contributions 9

1.4. The Second Generation in Focus $\quad 15$

Chapter 2: Mobilising for the 'Homeland' 21

2.1. Introduction 21

2.2. On Methodological Nationalism 22

2.3. Diaspora Mobilisation and Transnational Participation $\quad 30$

2.4. The Second Generation $\quad 42$

Part II: Here and There: Between Kurdistan and Europe 51

Chapter 3: The Kurdish Case 53

3.1. Introduction 53

3.2. Who Are the Kurds? 53

3.3. Kurdistan Divided - Historical Tour d'Horizon 58

3.4. Kurdistan in the New Millennium 69

3.5. Kurdish Nationalism(s) in the 21st Century 78

Chapter 4: How the Kurdish Diaspora(s) Came to Be 81

4.1. Introduction 81

4.2. The Dispersal and Exile $\quad 83$ 
4.3. Organised and Active: Kurdish Diaspora Online and Offline 92

4.4. Kurds in France 102

Part III: Mobilisation and Participation towards Kurdistan 111

Chapter 5: Mobilising in Paris 113

5.1. Introduction 113

5.2. Violence Far and Close 114

5.3. Means and Repertoires of Action $\quad 130$

5.4. What Affects Mobilisations? 145

5.5. Political Ambivalence: Terrorist or Not? 154

Chapter 6: The Second Generation 163

6.1. Introduction 163

6.2. Kobane Calling 164

6.3. Generational Particularities 173

6.4. Constructing 'Kurdistan' Online 181

Chapter 7: Diaspora and Beyond 193

7.1. Introduction 193

7.2. Growing Up Transnational 194

7.3. Other Dynamics 209

$\begin{array}{ll}\text { Conclusion } & 221\end{array}$

Appendix: Methodology 227

Material and Methods 227

Ethical Considerations $\quad 229$

On Naming 230

Notes 233

Bibliography 247

Index 273 


\section{List of tables, illustrations and map}

\section{Tables}

1. Chronological timeline of events referenced in the material 116

2. Vote share in diaspora and all counted votes

\section{Images}

1. Non-Kurdish associations mobilising in Paris for Kobane 136

2. Demonstration in Paris for the killed activists on 26 January 2013

3. Demonstrators marching in Paris on the World Day for Kobane, 1 November 2014

Map

1. The Kurdish-inhabited area 



\section{Abbreviations}

AKP The Justice and Development Party (Adalet ve Kalkınma Partisi)

CDK-F Kurdish Democratic Council in France (Conseil démocratique kurde en France, formerly FEYKA)

HDP People's Democratic Party (Halkların Demokratik Partisi)

ISIS The Islamic State in Iraq and Syria (Arabic acronym Daesh)

KCD-E European Kurdish Democratic-Societies Congress (Kongreya Civakên Demokratîk a Kurdîstanîyên Ewrupa, formerly known as KON-Kurd)

KDP Kurdistan Democratic Party (Partiya Demokrat a Kurdistanê)

KNC Kurdish National Council (Encûmena Niştimanî ya Kurdî li Sûriyê) 
KNK Kurdistan National Congress (Kongreya Neteweyî ya Kurdistanê)

KRG Kurdistan Regional Government

KRI Kurdistan Region of Iraq

MIPEX Migrant Integration Policy Index

MITT National Intelligence Organisation in Turkey (Millî İstihbarat Teşkilatı)

NGO Non-Governmental Organisation

PKK Kurdistan Workers' Party (Partiya Karkerên Kurdistan)

POS Political Opportunity Structure

PUK Patriotic Union of Kurdistan (Yekîtiya Nîștimanî ya Kurdistanê)

PYD Democratic Union Party (Partiya Yekîtiya Demokrat)

UNHCR United Nations High Commissioner for Refugees

YPG People's Protection Units (Yekîneyên Parastina Gel)

YPJ Women's Protection Units (Yekîneyên Parastina Jin) 


\section{Acknowledgements}

This book would not have seen daylight without the assistance and encouragement of a number of colleagues, friends and family members. Many thanks are due, but I wish to mention in particular Östen Wahlbeck, Sanna Saksela-Bergholm, Peter Holley and Saara Koikkalainen, who took time out of their busy schedules to meticulously comment on different versions of this book's chapters during our project meetings. I also warmly thank the anonymous reviewers for their insightful and thorough comments on this manuscript. The Academy of Finland-funded projects Civic Participation via Diasporic Circulation (project no. 287667) and Transnationalism as a Social Resource among Diaspora Communities (project no. 295417) both provided funding to complete this monograph.

As far as institutional support is concerned, I warmly thank the School of Advanced Studies in the Social Sciences (EHESS, École des hautes études en sciences sociales) in Paris, for hosting me during my fieldwork. I am also most grateful to the Kurdish Institute of Paris and its wonderful staff, which kindly received 
me during my researcher visit. I also wish to express gratitude to the Svenska social- och kommunalhögskolan (Swedish School of Social Science), at the University of Helsinki, and a very special thank you to the wonderful colleagues and friends at CEREN (The Center for Research on Ethnic Relations and Nationalism) for numerous coffee breaks, after-work meetings, casual corridor chats, and many other moments that so efficiently and luckily provided a welcome distraction from work-related tasks. You are one great bunch of people. Also, special thanks to Leena Kaakinen, Aino Rajala and Leena Rautjärvi at Helsinki University Press for your efficient input in practical matters related to this book.

Family and friends, you have been there for the ups and downs that I have lived through the past years when working towards the completion of this book. I could not have reached this very moment, adding final words to acknowledgements, if it had not been for you. A heartfelt thank you to my life partner, Jari Virman, for all the love, care and hope.

Last, but definitely not least, I wish to thank all the research participants who devoted their time and trusted me with their life stories. I cannot express how grateful I am that you sat down and shared with me your past experiences, views and opinions, and plans for the future. I truly hope that I have done them some justice and bear full responsibility for all the claims made in this book. This book could not have been completed without your generosity and kindness, for which I remain forever grateful. This book is dedicated to you. 
PART I

\section{Background}





\section{When Kobane Happened}

\subsection{Kobane Momentum}

Kobane became the buzzword in the fight against the so-called Islamic State (ISIS) in late 2014. Before September that year, the small Kurdish city located in northern Syria (Rojava), bordering Turkey, was barely known outside the region. Few outside Syria, even Kurds, would have been able to pinpoint the city on the map. This all changed between September 2014 and January 2015. The Syrian civil war, with its ever-growing human suffering and civilian death toll, had featured in the headlines since its outburst in March 2011. ISIS had ravaged the region and committed unspeakable atrocities as it had moved forward to invade new land areas. So, what exactly did happen in Kobane in 2014 that made the small Kurdish city known to the world?

In autumn 2014, the war in Syria took another turn as ISIS grew out of Al Qaeda in Iraq and gradually moved to invade great land areas both in Iraq and in Syria. In early 2014, the quickly advancing ISIS seemed unstoppable. In January, the organisation took over the Syrian city of Raqqa, declared it the capital of the emirate, and six months later declared the establishment of the 'caliphate'. In June, Iraq's second largest city, Mosul, fell under ISIS control, and, a month later, the US-led coalition started airstrikes against the organisation in Iraq. In August, ISIS started to carry out genocidal attacks on Yezidi Kurdish and other minorities in northern 
Iraq. ${ }^{1}$ It is estimated that around 10,000 Yezidis were slaughtered or abducted and sold into slavery. Some 40,000 to 50,000 Yezidis fled to Sinjar Mountain, where a week later Kurdish troops managed to secure a corridor for them to pass through Syria to the Kurdistan Region in Iraq. ${ }^{2}$

Five weeks later in September, ISIS arrived in the outskirts of Kobane. Having captured some 300 surrounding villages, the situation quickly escalated within the city and thousands of refugees crossed the border into Turkey. At the same time, the Turkish border authorities closed the border to Rojava, in an attempt to stop Kurdish combatants crossing over to the Syrian side and joining the battle for Kobane. Combatants outside Rojava poured in from the ranks of the Kurdistan Workers' Party (PKK) following the call by the jailed Kurdish leader Abdullah Öcalan in Turkey, and a number of international combatants joined the battle, including diaspora Kurds.

So began the siege of the city that would last till January 2015. The Syrian Kurdish Protection Units (YPG and its female battalion YPJ) led combat operations on land and were aided by Americanled airstrikes to deter the attacks and attempts by ISIS to take over Kobane. Both parties knew that a lot was at stake. If ISIS managed to capture the town, it would control a large section of the TurkishSyrian border and a long stretch extending from the province of Aleppo to Raqqa. On 26 January 2015, the siege finally ended with the defeat of ISIS, but the joy was overshadowed by the massive destruction that had fallen upon the city.

Nevertheless, the siege of Kobane quickly became symbolically significant - in the region and beyond it. First of all, the end of the siege was considered pivotal in the fight against ISIS, representing a first major defeat for the organisation that had seemed unstoppable. Indeed, the Kurdish troops were soon depicted as the only forces capable of deterring the organisation's attacks in the region. This was particularly the case after the massive breakdown of the Iraqi army and the flight of its soldiers during summer 2014 that left a sizeable arsenal of weaponry in the hands of the advancing ISIS. Kobane came to symbolise the victory over the barbaric 
enemy that had so far seemed undefeatable, and led to widespread mobilisations in Turkey, Iraq and Iran, mainly, although not exclusively, among the Kurds.

Secondly, the siege of Kobane threw the Kurds into the international spotlight. Situated in the border zone between Turkey and Syria, a large number of journalists and photographers could follow and deliver up-to-date news on the ongoing battle, visible from the hilltops located on the Turkish side. The world witnessed the siege in real time via the substantial video and photographic material that the army of journalists produced during the fourmonth siege. The siege featured almost daily in the headlines of prominent newspapers in Europe. The focus on Kurdish female fighters and the role women played in combat was unprecedented: the BBC even released a news story, titled 'The Kurdish Female Combatants Bringing the Fight to IS', accompanied by a short video documentary with nearly 1.3 million views on YouTube.

Thirdly, Kobane was highly significant for the Kurdish diaspora communities in Europe. During the humanitarian crises in Syria, diaspora Kurds had already engaged in providing material aid to the region. As the siege left the city of Kobane in rubble, diaspora Kurds participated in the reconstruction initiatives in the region. The international media and solidarity campaign initiated by Kurdish diaspora communities in Europe during Kobane proved to be 'decisive in mobilising an increasingly unified Kurdish response in opposition to ISIS' (Eccarius-Kelly 2017: 41). Tens of thousands of people, including, mostly but not only, diaspora Kurds, demonstrated in major European capitals and expressed their solidarity with Kobane (ibid; Schøtt 2021 forthcoming). In October 2014, about a hundred Kurdish protesters broke into the European Parliament in Brussels to demand international support for Kobane. Numerous seminars on the situation of Kurds were organised at the European Parliament, and TV channels allocated a significant amount of time to expert interviewees discussing Kobane. Also, the Kurdish troops' combat against ISIS increased the legitimacy of Kurdish political actors in the international political arena. 
Now, some seven years later, we can say that the memory of Kobane lives on. During the years following the siege, Kurdish diaspora communities have taken action to 'keep the memory of Kobane alive. Diaspora associations have organised the annual World Kobane Day in major European capitals to commemorate the battle, and to show solidarity and support for Syrian Kurds. Kobane was also frequently evoked during the siege of Afrin, a city on the Turkish-Syrian border that Turkish-backed militias moved to invade in 2018, following the withdrawal of US troops. The diasporic mobilisations for Kobane were largely interconnected with those among the Kurdish populations in their homeland. The significance of the siege was evidenced in the popularity of symbolic images, narratives and claims that circulated widely in the Kurdish territories, as well as in the diaspora.

\subsection{Kurdish Mobilisation in France}

Kurdish diasporic mobilisations for Kobane were visible on the streets of several European capitals between 2014 and 2015. For instance, Eccarius-Kelly (2017: 41) observes that 'Kurds showed unprecedented levels of unity in continental Europe and in the UK' during the siege. The mobilisations for Kobane were evidenced in large-scale demonstrations, and in efforts to raise awareness and expressions of solidarity that extended well beyond the diaspora communities. The mobilisation took more concrete forms when diaspora members sent material and humanitarian convoys towards Rojava in northern Syria. A number of diaspora members also joined the battle against ISIS, although most participated at a distance via humanitarian convoys and knowledge transfer during the stage of reconstruction. The siege of Kobane, to some extent, also transcended the political divisions that existed between diaspora groups and created nodes of solidarity between diaspora organisations and non-ethnic civil society actors in the host society (Eccarius-Kelly 2017; Schøtt 2021 forthcoming).

France makes an interesting case to study Kurdish mobilisations for several reasons. The Kurdish community in France mostly 
originates from the Kurdish regions in Turkey, and the migration patterns include both conflict-induced migration and labour migration dating back to the 1960s and 1970s (Hassanpour \& Mojab 2005). The formation of Kurdish diaspora communities in France is shaped by particular migration histories, settlement patterns and demographic characteristics. One particularity is also the relatively strong support that the pro-PKK movement holds in the country. The PKK has transformed from a military organisation in the 1990s to become a political and social movement that enjoys significant mobilising power and transnational networks in the diaspora, especially in France (Grojean 2015; Jongerden \& Akkaya 2016). The mobilisations for Kobane relied at least to some extent - on such pre-existing networks and associative structures.

At the same time, the PKK continues to be listed by the EU and the United States as a terrorist organisation, which means that the diasporic mobilisations took place in the context of political ambivalence towards the PKK movement, considered ideologically close to the Syrian Kurdish political leadership. One example showcasing this ambivalence was when the French president, then François Hollande, received three Kurdish leaders from Syrian Kurdistan to the Elysée Palace in Paris to discuss the future of Rojava, the autonomous region in northern Syria. This was strongly opposed by the Turkish president, Recep Tayyip Erdoğan, who equated the Syrian Kurdish forces with the PKK, which, as well as being listed as a terrorist organisation by the EU and US, was outlawed in Turkey. Regardless, the siege of Kobane and the visibility it received led to political outcomes (Kardaş and Yesiltaş 2017) and provided Kurdish political actors with the possibility to interact with high-profile European politicians, thus granting more legitimacy to Syrian Kurdish political organisations (Eccarius-Kelly 2017).

The critical events taking place in Kobane resonated particularly strongly among the Kurdish diaspora community in the French capital, which had also witnessed the assassination of three Kurdish women activists a year earlier. Three women were killed 
in the heart of Paris in January 2013, presumably by a member of the Turkish secret services, who had infiltrated the community and gained the trust of its members (Marchand 2017). One of the killed activists, Sakine Cansiz, was the co-founder of the PKK. The diasporic mobilisations in France were also shaped by these assassinations, as I will discuss later. Overall, the diasporic mobilisations in France were shaped by a series of events, including both in the country as well as in Kurdistan that experienced major transformations and political developments in the 2010s.

This book examines how a series of events that have taken place in the Middle East and in Turkey in the 2010s, including the siege of Kobane but not limited to it, have resonated in Kurdish diaspora communities in France. Critical events, such as Kobane, have mobilised the diaspora communities and their members in a multitude of ways and led to different forms of participation towards Kurdistan (Eccarius-Kelly 2017; Schøtt 2021 forthcoming). Firstly, the focus of this book is on how Kurdish diaspora communities in France have mobilised in the context of the Syrian civil war and the political unrest in Turkey and Iraq in the 2010s. It discusses events and analyses factors that have shaped mobilisation processes and participation in homeland affairs, including transnational opportunity structures, host societies' institutional and political opportunity structures, and integration regimes, in this case those in France. Secondly, it focuses specifically on how diasporic mobilisations were visible among second-generation members of Kurdish parentage in France, who mobilised, possibly in an unprecedented manner in the recent history of Kurdish diasporic mobilisations in Europe. Thirdly, it discusses the generational dynamics of diasporic mobilisations and activism, and what ramifications understanding such dynamics can bring to understanding diaspora contributions.

Based on these observations, I aim to address the following questions in this book:

1. How has the Kurdish diaspora community in Paris mobilised in the 2010s? What events have affected such mobilisation, and what factors have played into how diasporic claims and projects were formulated? 
2. How has this mobilisation affected the second generation? How to understand their local and transnational participation and mobilisation?

3. How to better grasp the potential of diaspora contributions from the generational perspective?

The Syrian civil war and the spiralling violence that has spilled over to Iraq and Turkey raises the question of what potential lies in diasporas once the war and violence has subdued and once the reconstruction begins. The last question specifically opens a venue to discuss how the Kurdish diaspora can contribute to post-conflict reconstruction and peace-building in Kurdistan. By maintaining dense transnational networks and active organisational life, the Kurdish diaspora has great mobilising power and is active in the host society's political and civic spheres, but the ultimate contributions that subsequent generations can generate towards the region remain largely unstudied.

\subsection{Diasporas as Non-state Actors: From Mobilisation to Contributions}

The Kobane siege is one example of critical events back home that can mobilise diasporas and prompt them to operate as nonstate actors towards the homeland. The phenomenon is not new in itself. Diaspora communities have a long-standing precedence of being engaged in nation-building efforts since the great migration waves of the 19th century and to homeland affairs even before that (Cohen 2008). Such long-distance participation has taken different forms depending on the diaspora communities' profiles, the needs of the 'homeland' and the possibilities in the host societies to contribute to the 'homeland'. Ranging from transnational political participation (Cano \& Delano 2007) to economic remittances and participation in development (Itzigsohn et al. 1999), to cultural exchanges (Itzigsohn \& Saucedo 2002: 768) - and often the combination of these (Portes, Guarnizo, \& Landolt 1999) diasporas' contributions towards the ancestral 'homeland' can be multiple and important in terms of development. 
Although the phenomenon is not new (Kivisto 2001; Dahinden 2017), the related research on diasporas' transnational participation in homeland affairs and on their cross-border engagements and activities dates to the latter half of the 20th century (Glick Schiller, Green Basch, \& Szanton-Blanc 1992; Levitt \& Glick Schiller 2004; Vertovec 2009). Such inquiries into migrants' cross-border attachments and ties often include case studies on particular diaspora communities. For instance, the Kurdish and Palestinian diasporas have been shown to have a long history of mobilisation towards homeland affairs, partially due to the state of statelessness and the experienced oppression in the states in which the Kurdish and Palestinian minorities are located (Baser 2015a; Mason 2007). More recently, diasporas have mobilised in the context of the Arab Spring and as a result of critical events taking place back home. This has been the case, for instance, with the Egyptian diaspora in the UK (Underhill 2016) and in Austria (Müller-Funk 2016), with the Syrian, Libyan and Yemeni diasporas in the US and UK (Moss 2016) and with the Tunisian diaspora (Graziano 2012), to mention a few. ${ }^{3}$

Different diaspora groups from the Middle East have participated in peace-making efforts in their conflict-ridden home countries (Baser \& Toivanen 2018a). Diaspora organisations can have a significant role in democracy-building and post-conflict reconstruction in different states or regions that are politically unstable and/or in the process of democratic transition. This has been the case for Kurdish diaspora organisations in northern Iraq (Østergaard-Nielsen 2003; Emanuelsson 2005), Somali diaspora organisations in Somalia and the self-declared Somaliland (see Kleist 2008a, 2008b; Pirkkalainen 2013), Turkish diaspora organisations in Turkey (Østergaard-Nielsen 2003) and Lebanese diaspora organisations in Lebanon (Hourani 2012; Pearlman 2014). ${ }^{4}$ On the other hand, the Syrian diaspora members have operated as brokers between the protest and mainstream media to raise awareness on the ongoing conflict (Andén-Papadopoulos \& Pantti 2013). Concerning the Kurdish diaspora, several studies have examined Kurdish diaspora mobilisation and diaspora politics 
during the past two decades (Wahlbeck 1999; Østergaard-Nielsen 2003; Emanuelsson 2005; Sökefeld 2006; Baser 2015a; Baser, Emanuelsson, \& Toivanen 2015; Baser 2019).

Diasporas can play a significant role in mobilising resources towards homeland development and in partaking in peacebuilding processes in conflict-ridden societies. The need to understand this role has become particularly acute in the current political context in the Middle East. Located within the national borders of Syria, Iraq, Iran and Turkey and dispersed around the globe, the Kurdish diaspora offers a case par excellence to study diaspora participation in homeland affairs and the motivating factors behind it. At the same time, dispersed around the globe in diaspora communities and with Kurdistan being divided across several nation-states, examining Kurdish diaspora mobilisation and the potential for homeland participation in the current political context in the region is particularly compelling as it provides insights into both 'homeland' and host society dynamics.

\subsubsection{The Kurdish case}

So why focus on the Kurdish diaspora? With a diaspora over a million strong (Wahlbeck 2007) and with dynamic transnational networks, relations and associative structures around the globe, the Kurdish diaspora presents an exemplary case to study the suggested topic. The Kurds are dispersed across Turkey, Syria, Iraq and Iran, with the unofficial region of Kurdistan lying at the heart of the current geopolitical struggles in the region. For this reason, the Kurdish population in the Middle East has been in the midst of the ongoing conflicts on several fronts - in northern Iraq, in northern Syria and in eastern Turkey. There is a long history of Kurdish migration from the region, which has led to the creation of vibrant Kurdish diaspora communities, mainly in Europe and North America. Fleeing persecution and conflict, but also motivated by work opportunities outside the region, the Kurds have settled and established active communities in the United States, 
Germany, France, the United Kingdom, the Nordic countries and several others (Hassanpour \& Mojab 2005).

The history of Kurds is marked by the long-standing political instability and conflict in the region (McDowall 1996). The current conflict dynamics and Kurdish societies look quite different from those of the 1990s or before (Gunter 2015). Indeed, Kurdish regions have experienced major changes in the new millennium. For instance, the Kurdistan Region of Iraq (KRI) experienced a significant economic boom in the 2010s and the Kurdistan Regional Government (KRG) has become a prominent actor in the Middle East since 2003, when the Ba'athist regime's reign terminated and Kurdish political actors replaced its political institutions (Aziz 2011: 79). In autumn 2014, ISIS rapidly seized large parts of Iraq, but by autumn 2017 it had lost nearly all of its previously invaded territories, and the final battle over Raqqa had just ended. In the light of this, the KRG held an independence referendum in September 2017, with a clear majority of voters (92.73\%) saying yes to independence - having also invited Kurdish diaspora members with Iraqi citizenship to participate.

Across the border in Turkey, the Turkish state has engaged in a four-decade-long conflict with the PKK. The ceasefire (19992004) between the PKK and Turkish state and the settled peace process that followed were fragile. The negotiations were effectively pursued until 2013, before finally collapsing in June 2015. Subsequently, both sides have resumed the armed conflict and the escalating violence has spread to the country's political sphere. The curfews imposed across largely Kurdish-populated towns and cities under a state of emergency have further exacerbated the security situation and led to an increased mobilisation in the diaspora. ${ }^{5}$

In northern Syria, the Democratic Union Party (PYD) took over the rule of Rojava in 2003, a year after the Syrian government forces withdrew from the region. The People's Protection Units that fought against ISIS in the liberation of Kobane have operated as the security forces of Rojava since 2012. Whereas the situation in Iraqi Kurdistan can be characterised as relatively secure 
in terms of autonomy and self-determination, this is to a much lesser degree in Turkish Kurdistan. Also, the situation has rapidly changed in Syrian Kurdistan, with Turkey launching a crossborder operation against the YPG/YPJ units in October 2019 and occupying parts of the territories that had previously been under the rule of the PYD.

Relatedly, the Kurdish societies in Iraq, Turkey and Syria are to some extent different from each other owing to different majority-minority relations and histories. In this sense, the Kurdish case also differs from other ethnonational diasporas, such as the Tamil and Palestinian diasporas, whose migration is traceable back to one nation-state. Divided into four nation-states and dispersed into diaspora communities around the globe, the Kurdish case offers interesting insights into how non-state actors, in this case the Kurdish diaspora, politically organises and mobilises in the context of war and conflict in the new millennium.

\subsubsection{Theoretical approach}

Diasporas, and the Kurdish diaspora especially, cannot be characterised as homogeneous entities. Today Kurdish populations form a rather heterogeneous group in terms of language, religion, political affiliation, residence in urban or rural settings, and place of living - in the Kurdistan region or in diaspora communities. Furthermore, the diaspora community is heterogeneous in terms of gender, age, generation, social class and so forth, which all shape individual diaspora members' positioning in the transnational space. At the same time, there are similarities concerning the understanding of 'Kurdishness', diaspora politics, transnational networks and relations, and political organisation across Kurdish communities in the diaspora (Østergaard-Nielsen 2003; Emanuelsson 2005; Baser 2015a). This does not, however, automatically mean that the mobilisation processes are similar, as also suggested by Bahar Baser's study (2015a). The dynamics of mobilisation and the possibilities to take part in homeland affairs can be considerably different depending on the hostland, where 
such efforts are organised and taken up, as well as on the transnational opportunity structures available for diaspora actors.

This study draws from a transnational approach, simultaneously engaging with it critically. Studies on Kurdish diaspora communities have abundantly employed the transnational frame (Baser, Emanuelsson, \& Toivanen 2015). This study also leans on literature that, in addition to the transnational focus, suggests that it is important to consider the national context in which diaspora formation has taken place. Several studies have shown that the formulation of diaspora organisations' activities need to be understood in relation to the host society context and how the incorporation regimes shape diaspora organisations' activities. For instance, the studies by Östen Wahlbeck (1999) on Kurdish diaspora communities' political activities in Finland and the United Kingdom, by Khalid Khayati (2008) on transborder citizenship and the narratives of victimhood among the Kurdish communities in France and in Sweden, and by Bahar Baser (2015a) on the Kurdish diaspora communities in Sweden and Germany show the significance of the national context in understanding diaspora mobilisations and political action. This means, for instance, examining the institutional and political opportunity structures, social policies, citizenship and incorporation regimes, political culture and minority-majority relations. This allows the fleshing out of any national particularities and factors that shape diaspora participation and mobilisation processes.

Therefore, the book provides insights into the significance of local settings, including the political and institutional contexts in France, and how such contexts condition mobilisation and structure diaspora participation to homeland affairs. At the same time, it includes a transnational approach in understanding how diaspora mobilisations and the related political action is organised, articulated and enacted in the transnational social space. This is particularly important as, in the latter part of the book, the focus is on the second generation. This also forces us to think of other dynamics that move the focus beyond national, transnational and diaspora lenses. 


\subsection{The Second Generation in Focus}

Between 2013 and 2015, it was the Kobane generation. (Interviewee)

In this book, I will focus on how diasporic claims and projects in Paris were formulated in the context of the armed combat between ISIS and the Kurdish military troops in the 2010s. In this way, the book contributes to the previous body of literature on diasporas' transnational participation towards the 'homeland' and the related mobilisation processes and does so in the context of recent political dynamics in the Middle East. Furthermore, I have particularly focused on the second generation of Kurdish parentage and examined how they have mobilised and engaged towards Kurdistan during the mobilisations that took place in the 2010s. The words above are those of a young interviewee belonging to the second generation. He referred to the 'Kobane generation', which ended up being in the title of this book. Generation, as discussed later, forms one of the key concepts and themes running throughout this study.

There is an abundant literature on how migrants' children, the so-called second generation, engage in transnational activities and networks (Baser 2012, 2014; Beauchemin, Hamel, \& Simon 2010; Eliassi 2010; Lee 2008; Levitt 2009; Levitt \& Glick Schiller 2004; Levitt \& Jarowsky 2007; Levitt \& Waters 2006; Premazzi et al. 2013; Somerville 2008; Toivanen 2014) or even 'return' to the sending region of their parents (Fokkema, Cela, \& Ambrosetti 2013; King \& Christou 2010, 2014; Potter 2005; Teerling 2011). Concerning studies on the Kurdish second generation, their role in diaspora organisations has been the subject of few studies (Baser 2012; Mügge 2010). There are also few studies on the second generation in relation to Kurdish diaspora mobilisation and politics. These include the works by Liza Mügge (2010) on the second generation of colonial migrants and guest workers in the Netherlands and by Baser (2015a) on the Turkish and Kurdish second generations in Germany and Sweden. The 
formation of the Kurdish diaspora dates back to the second half of the 20th century, which also means that the current diaspora communities consist of not only well-settled communities and more newly arrived members but also the second and subsequent generations born in their parents' societies of settlement. The means and motivations to take part in 'homeland' development might be considerably different for migrants' children, the socalled second generation born outside Kurdistan, as their experiences of the 'homeland' are quite different from those of their parents (Alinia \& Eliassi 2014).

This book opens venues to study the potential that lies in the Kurdish diaspora in terms of transnational contributions towards Kurdish societies in the region. Similarly to Baser's (2015a) study, this book also includes a focus on the Kurdish second generation, with the distinction that it examines their participation in 'homeland' affairs. Indeed, what is still largely missing in studies that concentrate on diasporas' transnational engagements is a focus on the second generation's transnational participation from the perspective of diaspora contributions. There is a need to better understand how mobilisation processes relate to transnational participation towards the ancestral 'homeland' among the second generation. The question of transnational participation touches upon that of mobilisation and relatedly of motivations to take part in transnational participation towards the ancestral 'homeland'. In the context of current events in Kurdistan, we also need to ask what motivates the diaspora's participation in homeland affairs, particularly among the younger generations, and to do this in a way that considers their lived realities, which are not (only) limited to the diaspora context. One way to do this is to take into consideration how the second generation's contributions and participation, as well as the related motivations, means and know-how towards the 'homeland', possibly differ from those of their parents.

This book opens questions on second-generation participation towards the ancestral 'homeland' that may differ from their parents' participation and motivations to contribute to homeland 
development. Furthermore, it acknowledges that the second generation does not always have similar interests or views on politics as their parents' generation, as their reasons to mobilise can extend beyond traditional (diaspora) politics and be shaped by political structures, political culture and transformations taking place in the host societies - and more globally. Indeed, their political activism and mobilisation can also be transcribed into more global transformations in political subjectivities that particularly concern their age cohort. I argue that, in order to better understand different forms of social and human capital that the secondgeneration members possess to engage transnationally towards their ancestral 'homeland', we need to consider the generational dynamics more broadly than merely limited to the understanding of the 'migrant' generation.

Therefore, this book also urges researchers to examine secondgeneration members' transnational participation and role towards diaspora contributions in a way that moves beyond the 'ethnic' lens. In other words, this book also asks to what extent it is justifiable to approach second-generation members' political dis(engagement) through the diaspora lens, and what other dynamics need to be considered to better grasp their role in diaspora contributions. Such other dynamics at play that are more rarely the topic of discussion include the changing nature of political activism and the very notion of what 'political' means for that particular generation, in this case meaning the age group. Therefore, 'generation' forms the central theme in this book, and it is approached both as referring to the 'migrant' generation (that is, 'second generation') and as belonging to a particular age group of young adults. Coming back to the term 'Kobane generation', the central question in this book is not formulated in terms of whether there is or not a Kobane generation. Instead, the book focuses on analysing how the Kobane generation came into being and how it manifested itself in the midst of the Kurdish diasporic mobilisations in Paris in the 2010s. These mobilisations were triggered by a series of events, as discussed later, particularly among them the Kobane siege and the assassination of three Kurdish activists in Paris. 


\subsubsection{The fieldwork}

I finalised my doctoral research and defended my thesis on negotiations of belonging among second-generation Kurds in Finland in August 2014, immediately before the siege of Kobane started. To show their solidarity with Kobane, demonstrators took to the streets in Paris, London, Berlin and Stockholm, as well as in Helsinki, where they protested against the looming occupation of the city by ISIS. In Paris, an unprecedented number of secondgeneration Kurds took part in protests and felt concerned by Kobane. The critical events taking place in Kobane resonated particularly strongly among the Kurdish diaspora in the French capital, which had witnessed the assassination of three Kurdish women activists a year earlier. The women were killed in the heart of Paris in January 2013, presumably by a member of the Turkish secret services, who had infiltrated the community and gained the trust of its members (Marchand 2017).

It was in this context that I started my fieldwork in Paris in 2016, interviewing first- and second-generation Kurds and attending political meetings, cultural events, demonstrations, exhibitions, film festivals and other get-together events organised by the community members. In the meantime, the situation in the Kurdish regions was rapidly shifting and the mounting violence since summer 2015, which continued till 2016, also became reflected in the Kurdish diaspora members' activities in France, a great number of whom had migrated from Turkey. At the same time, there was a boom of cultural production in the Kurdish diaspora in Europe. This became particularly visible in the form of Kurdish film festivals and photograph exhibitions, which were numerous in Paris and which often featured images of the Kurds' combat against ISIS, including Kurdish female combatants from Rojava.

The book is based on the material that I collected, mainly between 2015 and 2017 in France. The main material consists of interview material with first- and second-generation Kurds in Paris, whereas other material includes written interviews, online material, and observation notes from different events I attended 
and was invited to. I paid careful attention to research ethics in all stages of the fieldwork, including in terms of what terminology to use. This is not least because the Kurdish question is a sensitive one and naming carries social meanings (Toivanen \& Baser 2018). I also fully acknowledge the possibly severe consequences for those members active in diaspora organisations in the event of careless data preservation or treatment. I have set out this study's methodological premises, including the ethical questions, in more detail in the Appendix: Methodology.

\subsubsection{Structure}

The book is divided into three parts. The first, titled 'Background', introduces the topic, and lays out the central questions that are tackled in the following chapters. It also provides an overview of the related theoretical and empirical debates concerning diaspora mobilisation and transnational participation towards the 'homeland'.

The second part, titled 'Here and There: Between Kurdistan and Europe', provides a historical and current-day contextualisation on the underlying geopolitical tensions and divisions that today still structure the conflictual dynamics in the region - and in diaspora. It also offers more information on the formation of Kurdish diaspora communities outside the borders of Kurdistan and shows how, over the decades, the diaspora created vibrant transnational networks of associative life and political organisation, including in online spaces. In relation to this, the formation of the Kurdish diaspora in France is discussed in more detail.

The third part, titled 'Mobilisation and Participation towards Kurdistan', includes three analysis chapters. The first discusses the mobilisation and transnational participation of Kurdish diaspora communities in France in the 2010s. It shows how a series of critical events shaped mobilisations in Paris, what repertoires of action the mobilisation entailed and what factors shaped the observed mobilisations. The latter part of this chapter discusses the mobilisation in Paris in the context of political ambivalence towards the Kurdish question, namely concerning 
the criminalisation of the PKK in the EU countries, including in France.

The second analysis chapter focuses specifically on the second generation. I will first discuss the second generation's transnational participation and its generational particularities, before moving forward to discuss the online dimension of such participation. The third analysis chapter questions the extent to which the second-generation participation towards Kurdistan should be understood as a form of ethnonational participation or a manifestation of diasporic belonging, and to what extent it reflects other dynamics at play that cannot be limited to explanations via the 'ethnic' or 'diaspora' lens. The book ends with a conclusion chapter in which I open up new venues for looking at the potential of diaspora contributions. 


\section{Mobilising for the 'Homeland'}

\subsection{Introduction}

This chapter discusses the conceptual approaches to diasporic mobilisation and homeland participation, including a focus on their generational dynamics. How can we best understand diasporic mobilisation processes? It has been suggested that many questions remain unanswered concerning diasporas, concerning namely their ability, willingness and extent to mobilise (Beyene 2015; Mavroudi 2018). Such questions deal with, for instance, whether we can assume that diasporas act as a collective instead of paying attention to individual actors (Fiddian-Qasmiyeh 2013) and whether we can assume that mobilisations are directly linked to questions of diasporic identity and belonging (Faist 2008).

These questions particularly raise the concern over how to understand and approach diaspora mobilisations in all their complexity. I find the criticism that has been presented towards the nation-state and ethnicity-centred epistemology (that is, methodological nationalism) that underlies a large share of the migration research particularly relevant in this regard (Bommes \& Thränhardt 2010; Dahinden 2016; Pries 2005; Wimmer \& Glick Schiller 2002). As Dahinden (2016: 2211) notes,

A problem of an epistemological nature is created, however, when researchers accept and reproduce them without reflection 
by enlisting migration or ethnicity as the central criterion of difference in research questions, research design, data collection, analysis and theory, even when it may not be empirically relevant.

Concerning the topic of this particular study, this means questioning what actually constitutes a 'diaspora' and 'mobilisation', instead of taking them at face value, and how to understand individuals' motivations and ways to mobilise and (dis)engage politically from the perspectives that move beyond migration theories. In this study, I have leaned on the observations by Janine Dahinden (2016: 2213-2218), who calls for us to 'de-migrantize' migration and integration research by outlining three different strategies. The first is to distinguish between analytical and common-sense categories (see also Brubaker 2002), the second is to move migration theory into closer communication with social theory, and to 'remove it from its "migration container", and the third is to 'change the object of study from the migration population to segments of the overall population'. These strategies and the main debates concerning methodological nationalism and transnationalism will be explored next.

\subsection{On Methodological Nationalism}

In terms of volume, an unprecedented number of people, but also goods and ideas, are on the move. They are crossing nation-states' borders, which became more or less established in the course of the latter half of the 19th and especially the first half of the 20th century. Nationalism, one of the most powerful ideologies of past two centuries, was paradoxically a very global idea to begin with. Its central premise was (and continues to be) the idea of a nation-state - a seamlessly overlapping configuration of a nation within a state. This has long proven to be a myth - albeit a very powerful one.

As Benedict Anderson (1991) has suggested, nations are 'imagined political communities'. They are 'imagined' in the sense that, unlike families, nations' members do not know each member that feels a belonging to such an entity, yet this does not prevent feeling 
a sense of belonging to such a socially constructed community, that is, a nation. Cutting through linguistic, ethnic and religious communities, nation-states' frontiers, and national identities, have become to be considered something natural and of long precedence. This is the case with France, where the respondents of this study lived and where the notion of national belonging is very closely associated with civic belonging to the state. The fact that nation-states are constructed along man-made boundaries is perhaps even more striking with the country of birth of many first-generation respondents - Turkey - the state whose modernday boundaries were designed in the early 20th century and have been considered indivisible ever since.

Yet, the idea that the world could be structured into clear-cut nation-states with more or less homogeneous national communities and identities was effectively naturalised and normalised in the course of the previous century. The scientific community and academic research have not stood aside in this process of normalisation, so to speak, and the very conceptualisations that should have critically approached naturalised and taken-for-granted understandings of nation-states and their allegedly sedentary peoples have instead been (and to some extent continue to be) coloured by nation-state-centred thinking. Social scientific research on international migration is one field where such approaches have dominated conceptualisations. For instance, migration is quite readily understood as a term that refers to inter-national migration, to mobilities that cut through nation-states' borders, instead of mobilities between regions, cities or neighbourhoods.

The tendency of researchers to adopt a nation/state/society as the primary unit of analysis to study migration-related phenomena has been named methodological nationalism. Andreas Wimmer and Nina Glick Schiller (2002) convincingly argue that nationstate building processes have fundamentally shaped how migration has been perceived and reacted upon. This has also meant that academic studies on international migration have been coloured by a nation-state-centred mode of thinking and that researchers have treated migration-related phenomena as taking place 
between particular nation-states. That is why, in earlier studies on migration and to some extent still, Kurdish migrants' routes of mobility would have been approached as a departure from Turkey and as an arrival and settlement in France. Within this logic, it would be tempting to treat their stories first and foremost as ones of forced displacement from Turkey to the integration in France. However, human experiences, activities, attachments, ties and identities are rarely limited within the parameters of the nationstate that we happen to inhabit or the borders across and beyond which we tend to move.

\subsubsection{Transnationalism}

Indeed, the need to move away from methodological nationalism and to better understand the lived experiences of people who take part in migration movements and what happens after migration prompted the emergence of a new theoretical framework in the early 1990s - that of transnationalism (Vertovec 2009). The emergence of transnational conceptualisation took place in the context of the late 20th-century globalisation, and transnationalism quickly became a conceptual buzzword in migration studies. The classical and rather general definition of transnationalism defines it as 'processes by which immigrants build social fields that link together their country of origin and their country of settlement' (Glick Schiller, Green Basch, \& Szanton-Blanc 1992: 1). Therefore, closely linked to processes of globalisation, theorisation on migrant transnationalism has emphasised the cross-border contacts that migrants maintain even after migration processes ( $i b i d$.). This means that migrants are not simply seen as operating within one state and then moving from it to another. Instead, their social spaces and relations, as well as lived experiences, extend beyond national frontiers.

Indeed, transnational theorisation emphasises the fact that migrants are individuals who operate in transnational social spaces (Bauböck \& Faist 2010) or social fields (Levitt \& Glick Schiller 2004). This means that they 'develop and maintain multiple 
relations - familial, economic, social, organizational, religious, and political that span borders' and that they are also actors who 'make decisions, and feel concerns, and develop identities within social networks that connect them to two or more societies simultaneously' (Glick Schiller, Green Basch, \& Szanton-Blanc 1992: $1-2)$. In concrete terms, this can mean, for instance, keeping in touch with family members back home and helping them economically, as well as following the homeland events and news, voting at a distance in embassies or consulates and visiting or even contemplating a return to the ancestral 'homeland'. Also, it is not surprising as such that the transnationalist turn in social sciences is often associated with globalisation processes and with technological developments. They have been credited with having enhanced transnational migrant connectivities via the rise of ICT tools and new communication technologies (ibid.; Dahinden 2012; Candidatu, Leurs, \& Ponzanesi 2019).

The transnational frame does have explanatory power in capturing cross-border processes, social formations, transactions and flows that condition and shape individuals' actions, relations and attachments. But Dahinden (2009) aptly asks: are we all transnationalists now? This question contains a reference to criticism that has been presented towards the transnational frame for its overtly celebratory tones (Kivisto 2001; Harney \& Baldassar 2007). Also, Anthias (2009) warns of the risks of methodological transnationalism, and argues against the polarisation between the national and a transnational perspective. She suggests that a truly transnational perspective 'needs to locate relations between nations and nationally based social hierarchies as well as those on a global level and then begin to think about how those are transformed when transnational processes are at work' (p. 5).

\subsubsection{Ways forward}

Indeed, there has been increasing criticism towards the nation-statecentred logic in migration research (Bommes \& Thränhardt 2010; Pries 2005; Wimmer \& Glick Schiller 2002). I find Dahinden's 
(2016) suggestions to adopt three strategies to 'de-migranticize' migration research quite pertinent to remedy those risks. Firstly, she suggests that there is a need to distinguish between the common-sense categories and analytical categories (see Brubaker 2002). This, she notes, is particularly significant when studying collective action and political mobilisation, where essentialised notions of ethnicity and group belonging are often instrumentalised. Instead, denying the significance of such essentialised claims, she suggests (2016: 2213) that:

Rather, the ways in which ethnicized and 'migranticized' worldviews - of individuals, in institutions, in politics, etc. - are created, how they exist, change and interact with other perspectives of difference are themselves objects of investigation.

Secondly, she suggests that there is a need to link migration research to the analytical categories of social sciences more broadly. This, she argues, will allow for greater reflexivity concerning how certain terms and concepts have been normalised. As one example of this, she refers to how migration scholars have focused on kinship and family networks, or other ethnic networks, without including social network structures in an encompassing way. This also means, according to her, that migration and ethnicity 'no longer automatically enter into the research question and research design as categories of difference' but come to the picture in a second step (p. 2214). Thirdly, she argues for a reorientation of the units of analysis from the migrant population towards the overall (or parts of the) population. This means steering away from employing a migrant population as a unit of analysis, and directing the focus towards the overall population, to which the migrants also belong. These strategies, according to Dahinden, mean that the research questions lose their migration-specific focus 'while remaining sensitive to the role of migration and ethnicity in the phenomenon being investigated' (p. 2218). I will return to these strategies later in the analysis chapters. 
So, where does all of this leave the nation-state? Regardless of the relationship between the increased cross-border flows and globalisation, it is also hard to entirely disregard the significance of the nation-state and the role it plays in individuals' lives. For instance, states still largely control who can cross borders and enter national territories and who cannot. One's citizenship status, still in most cases granted by the state where one happened to be born, provides unequal possibilities to international mobility. Besides the physical borders that demarcate the national frontiers, the discursively constructed idea of a nation-state (and that of nations) as a naturalised entity also persists and its significance in the everglobalised world does not seem to wear off. On the contrary, if anything, we have witnessed the resurgence of nationalist sentiment in Europe in the new millennium that has evoked some very heated discussions on the 'threats' of migration and on the need to protect the 'integrity' of national communities. We have also borne witness to the claims put forth by the Scots, Catalans, Kurds and other ethnonational minorities who are calling for a greater degree of self-determination and/or organising independence referenda within the nation-states they inhabit. So, to what extent do nation-states still matter or are we all transnational now? What significance do states' borders and national spaces have in today's globalised world? These questions are particularly challenging if we think of the Kurdish case, and if we are to ask questions such as: what geographical, social and political frontiers possibly delineate the limits of a Kurdish nation?

\subsubsection{Kurds as a transnation}

In the 20th-century nation-state-building frenzy, a number of peoples that had increasingly come to consider themselves nations were either divided by national borders or left without a state. This was the case for Kurds, as discussed in previous chapters. Despite all divisions and fragmentation, the Kurdish nation provides a very good example of a modern-day nation without a state and it is often referred to as 'the largest nation without a state'. In this sense, 
the Kurdish nation can to some extent be considered a transnation, currently existing as minorities scattered mainly across four nation-states in the Middle East. In reference to the nation-state categorisations, Kurds have also been referred to as a 'proto-nation' (Hylland Eriksen 1993: 14), that is, a nation without a state. I find the term transnation a bit more apt to highlight the fact that the state-political division of Kurdistan does not neatly line with the social, familial, linguistic and cultural frontiers of its people.

In addition to the four parts that are commonly referred to as Kurdistan, the 'Kurdish nation' is said to have a 'fifth' part outside Syria, Iraq, Iran and Turkey. This 'fifth' part is the Kurdish diaspora that is scattered, mainly, across North America and Europe (Hassanpour \& Mojab 2005). This means that the Kurdish nation is a transnation also in the sense that its members foster and maintain cross-border networks, linguistic and religious affiliations, familial ties and so forth that transcend the nation-states' borders both between the Kurdish communities settled outside Kurdistan and between those within the geographical area of Kurdistan. For instance, Anne-Sofie Schøtt (2021 forthcoming) employs the term alter-territoriality in her study on the Kurdish mobilisation in Denmark. By this, she refers to diasporas having an orientation towards the transnational community and a reorientation towards the homeland, albeit a different part of it than where the diaspora originates. This term will be discussed in more detail in the analysis chapter but suffice to say here that is important to employ the transnational frame broadly and not only to include the countries of settlement and departure but also to consider the transnational constellations that exist in the diaspora as well as in the sending region. It is also relevant to point out that the Kurdish case differs from other ethnonational migrant communities that have been exiled from within a specific nation-state, such as the Tamils, and whose actions and mobilities are also directed towards one specific state, in the case of Tamils towards Sri Lanka.

Accounting for transnationalism in the sending region does not mean entirely discounting the national context. The Kurdish 
communities in Kurdistan are scattered across four different nation-states, in which they have been and continue to occupy a minority position. The Kurdish minorities have experienced quite different majority-minority relations, which have consequently shaped claims made towards greater self-determination: they have greatly varied from territorial claims to demands for more linguistic and cultural rights. On the other hand, the relations between the so-called fifth column of Kurdistan, the diaspora, and different homeland actors are also affected by the state of statelessness and shaped by the different national spaces in which Kurdish communities form minorities. The diaspora's mobilisation and participation towards the 'homeland' and the related claims-making differ in relation to which state it is targeted towards and in which state such claims are presented. For instance, the ideologically close Kurdish movements in eastern Turkey and northern Syria operate in very different national spaces and their claims are formulated a bit differently towards the Turkish and Syrian political actors. Simultaneously, events in northern Syria (such as Kobane) can generate mobilisation among Kurdish communities in Turkey as well as among those in the diaspora, who have migrated from Turkey - thus making the transnational constellations of different Kurdish movements in that particular region, and how those play out in the related ideologies and actions, difficult to ignore.

Indeed, the complexity of the Kurdish issue, including the state of statelessness of Kurdistan, the division to different nation-states in the region, and the dispersal of Kurds in diaspora communities across a great variety of different states, mostly in Europe and North America, defies the methodologically nationalist perspective but does not comfortably sit within the transnational frame either. If we are to understand the mobilisation and participation of Kurdish diaspora(s) towards the 'homeland', including that of the second generation, a conceptual approach that moves beyond transnationalism and the methodologically coloured approach is needed. 


\subsection{Diaspora Mobilisation and Transnational Participation}

\subsubsection{About 'diaspora'}

When speaking of diasporas, the classical and prototypical case of the Jewish diaspora comes rapidly to one's mind, one that is exiled and dispersed around the globe following a traumatic event or events (Cohen 2008). In a sense, diaspora is very closely related to the notion of transnationalism: whereas transnationalism has been used to refer to migrants' cross-border ties across countries, diaspora is employed to 'denote religious or national groups living outside an (imagined) homeland' (Bauböck \& Faist 2010:9). Cohen (2008) distinguishes four phases that diaspora studies have gone through, each having a bit different understanding and approach to the term. The most classical and prototypical definition of Diaspora (often capitalised) was that employed for the Jewish, African, Armenian, Irish and later Palestinian experiences of forced exile. The term diaspora denotes in its most classical meaning a sense of forced migration (displacement), a level of consciousness of the homeland and expressed collective memory, feelings of alienation in the society of settlement, feelings of longing, and eventually return to the imagined homeland and commitment to the restoration of the original homeland (Safran 1991: 83-84, 179-180). The term expanded in the 1980s, to include different categories of people: 'expatriates, expellees, political refugees, alien residents, immigrants and ethnic and racial minorities tout court', as noted by Safran (1991: 83). The third phase was characterised by a social constructionist take on the term: it sharpened the idea of 'homeland' as separate from 'ethnic/religious community', and (Cohen 2008: 1-2), suggesting, similarly to the fourth phase, that identities are very much deterritorialised but that diasporas can still be understood as having an idea of 'homeland' and an orientation towards it. Since then, the term 'diaspora' has been greatly diversified to include various denotations, groups, collectivities and social formations (Brubaker 2005; Cohen \& Fischer 2019). 
What about the Kurdish communities outside Kurdistan? ${ }^{6}$ The Kurdish diaspora seems to tick all the boxes in terms of both the more classical as well as the more social constructionist definition of diaspora. However, Rogers Brubaker (2005) warns against the risk of what he calls 'groupism' when thinking of diasporas. By this, he refers to 'the tendency to take bounded groups as fundamental units of analysis' (p. 2). In other words, he suggests that there is a risk to take diasporas as clearly cut, substantial entities, a risk of reifying 'diaspora' by attributing it with a certain list of characteristics, such as ethnicity, national origin, language, ancestry and so forth. So where does this leave us? What utility does the term 'diaspora' hold, then, and should it be used at all?

Wahlbeck (1999) has argued that the Kurdish communities outside Kurdistan constitute a diaspora not only in the descriptive sense of the term but also in its analytical sense. He (1999: 180) further observes how the social organisation of the diaspora community is characterised by transnational social relations and suggests that the concept of diaspora is a useful one to understand the transnational social reality in which migrants are embedded. In other words, the concept of 'diaspora' can be useful to make sense of exiled communities' social space and organisation, and how such social and transnational space in the context of diaspora movements can offer, assign value to, and devalue collective (identity) narratives for diaspora members and possibly inform them about linguistic and cultural matters related to the 'homeland'.

For instance, concerning the Kurdish diaspora, the narrative of victimhood as a result of traumatic experiences back 'home' followed by exile has been suggested to shape the constructions of diasporic identities as well as to structure transnational action towards 'homeland' (Khayati 2008). Although Khayati (2008: 5-6) suggests that there is a need to move beyond 'the experience of pain and trauma and the sense of victimhood in order to depict a multitude of other diasporic situations and trajectories, such as institutional and transnational arrangements', Kurdish political mobilisation narratives and justifications for action still reference the collectively experienced trauma and victimhood, if not as the 
central then as one major component of the 'Kurdish experience'. How then can we examine Kurdish diaspora mobilisation, where Kurdish protagonists themselves refer to Kurds as an ethnic group with mutual political aspirations and interests, without essentialising the political actions, narratives and motivations to all Kurds? Brubaker (2005: 12) suggests that we should think of diaspora in the first place as a category of practice, in other words how claims are made, projects articulated and loyalties evoked and mobilised through it, and only then think about whether and how it could serve as a category of analysis (see Anthias 1998; Dahinden 2016). He further notes that, 'rather than speak of "a diaspora" or "the diaspora" as an entity, a bounded group, an ethnodemographic or ethnocultural fact, it may be more fruitful, and certainly more precise, to speak of diasporic stances, projects, claims, idioms, practices and so on' (2005: 13). Therefore, instead of asking what diasporas are, perhaps the question ought to be how diasporas come to be. Is it diasporas who engage in mobilisation and make it happen, or is it through the processes of mobilisation that diasporas come to be?

Indeed, Sökefeld (2006) suggests that it is the latter, and posits that diasporas, indeed, need to be thought of as imagined transnational communities that come about through specific processes of mobilisation. Basing his argument in the literature on social movements, he suggests that this enables the countering of essentialist understandings of diaspora (and in extension of transnational political action) as rooted to a sense of belonging and the 'roots' migrants have in their 'homelands'. If we are to draw from Sökefeld's understanding of diasporas as specific processes of mobilisation, it can be concluded that the diasporas come about not only through exile but first and foremost through homeland orientation and how group solidarity is mobilised and maintained to such effect. With a similar approach, Brubaker (2005: 5) has posited that, despite the fragmentation of the term, there are 'three core elements that remain widely understood to be constitutive of diaspora': dispersion (either voluntary or involuntary), homeland orientation (whether real or imagined) and boundary 
maintenance (how group solidarity is mobilised and maintained) (see also Cohen 2008: 12). In reference to the first, it can be concluded that not all exiled communities are diasporas, but all diasporas are (at least to some extent) exiled communities that come about as a result of specific mobilisation processes that consist of 'diasporic stances, projects, claims, idioms, practices and so on' (Brubaker 2005: 13).

\subsubsection{Mobilising for 'homeland'}

Diasporas can play multiple roles in both the host country and homeland contexts (Toivanen \& Baser 2020). Political activities that have been focused upon in previous literature can range from taking to the streets and organising demonstrations to circulating petitions, lobbying, campaigning to raise awareness, and providing logistic support in times of political disturbance back 'home', just to name a few examples (ibid.). For instance, the annual organised demonstrations in Strasbourg to call for the release of the jailed Kurdish leader Abdullah Öcalan attract thousands of Kurds from France, Germany, the United Kingdom, Sweden, Norway, Finland and other countries to attend. Kurdish diaspora organisations and political actors in the diaspora have also mobilised to lobby host country decision makers on genocide claims (Baser \& Toivanen 2017), to raise awareness for human rights violations committed 'back home' (Baser 2016), to shed light on the ongoing conflict (Eccarius-Kelly 2017; Karagöz 2017), and to take part in transnational diaspora politics with the aim of having an impact on the political processes back 'home' (Emanuelsson 2005; Mügge 2010; Østergaard-Nielsen 2003).

So, how can we approach the mobilised action without essentialising it simply as a manifestation of the diaspora's nationalist feelings towards the 'homeland' or as a lack of integration in the host society? When examining diaspora mobilisation, there is a risk of not only taking the diaspora as a uniform actor but also of treating diaspora mobilisation as something taking place between the host society and the 'homeland'. Indeed, traditionally, diaspora 
politics have been analytically approached through the triad relationship between the 'homeland', the 'hostland' and the 'diaspora' (Demmers 2002; Vertovec 1999). However, diaspora mobilisation and the political and civic action that it can generate takes place in the transnational space. This means that the networks, affiliations, practices and narratives that are part of mobilisation processes are very transnational, and approaching them within the triangle of the host society, the 'homeland' and the diaspora can lead to disregarding other dynamics that might be at play. For instance, Alinia (2004: 211-212) in her research on the Kurdish diaspora in Sweden suggests that the fact that Kurdistan does not exist as a state can lead to feelings of ambivalence towards the societies of departure and to several distinctions concerning the meanings assigned to 'homeland'. This can also shape different diaspora communities' mobilisation towards the imagined 'homeland' in very different ways. Secondly, there is a risk of essentialising diaspora mobilisation and the related political and civic actions as a manifestation of diaspora members' lingering loyalties and attachments towards the ancestral 'homeland'. Alinia (2004: 330) provides another take on such conflation between mobilisation and loyalty by arguing that Kurdish diasporans' 'transnational networks and communities, social relations and activities regarding the politics of location have in this process become their "home".

Simultaneously, diaspora mobilisation cannot be dealt with separately from 'homeland' events. The question on what generates and affects the ways in which diasporans mobilise has long puzzled scholars. Safran $\left(2007^{7}\right)$ suggests that 'diaspora consciousness may be revived after a special event, such as a revolutionary struggle or a tragic experience, that brings back the importance of the kinship connection'. The mobilisation can be sparked by critical events that touch upon the exiled diaspora community and its members, and, for instance, the stage of the ongoing conflict in the 'homeland' can create waves of protest in the host country. Also, past events can be referenced upon and represented as a continuity of the ongoing struggles - or vice versa. Sharon Macdonald (2012: 235) has referred to this as 'past presencing', in other words, how 
the past is made relevant in different ways in the present. Orjuela (2018: 3) interestingly expands this approach to diaspora mobilisation to look at how 'versions of the past can be represented and performed for instance in court rooms, demonstrations, on-line campaigns and at commemoration events. This is close to Volkan's idea of 'chosen traumas', in other words of 'a shared mental representation of a traumatic past event' that over generations gradually becomes a significant group marker of identity that can then be reactivated by political leaders to reconfirm such identity. For instance, the Iraqi Kurdish diaspora's chosen trauma has, in this sense, been the Anfal campaign, and diaspora actors' initiatives to push for its recognition as genocide have enabled them to create networks both in host society political circles and with homeland actors (Baser \& Toivanen 2017).

Little is known about why some diaspora members are more engaged and mobilised than others (Fiddian-Qasmiyeh 2013). One explanation is that 'homeland' events resonate very differently between different diaspora members, for instance between first- and second-generation members. Individuals and members of different generations are also socialised differently into the (diaspora) political cultures through their parents and their networks (Karagöz 2017: 91). Transnational engagements can also shift in time and the level of mobilisation depends on the shifting emotions diaspora members have towards the 'homeland' events (Mavroudi 2018). Diaspora members who have been more passive and 'dormant transnationalists' (see Shain \& Barth 2003) can become activated in the aftermath of major political disturbances in the 'homeland'. This was visible, for instance, in the case of the so-called Arab Spring, which led to political mobilisation among Arab diasporas in Europe (Beaugrand \& Geisser 2016), or, as this book will show, with the events that took place in Kobane in the winter of 2014-2015.

Diaspora political actors can be particularly central in this regard. Adamson (2013: 69), who has studied the mechanisms of diaspora mobilisation in the case of the Turkish-Kurdish conflict between 1980 and 2000, refers to transnational brokerage. 
Transnational brokers are political entrepreneurs (associations, individuals, political wings) who successfully connected diaspora populations (and their resources) in Europe to the Kurdish actors in Turkey, and made the Kurdish case visible to European policymakers. In addition to successful lobbying, they also managed to mobilise Kurdish community members in Europe to join politically dynamic networks of Kurdish associations (see also Baser 2015a: 33-34). Linking this to the earlier approach of diasporas coming about as processes of mobilisation, Adamson (2008: 2) argues that diasporas 'are best viewed as the products or outcomes of transnational mobilisation activities by political entrepreneurs engaged in strategic social identity construction'.

This also relates to Brubaker's (2005: 30-31) observations on how researchers need to distinguish the ethnopolitical categorisations that are employed by (diaspora) political actors from the analytical categorisations to better understand ethnopolitics. The focus, therefore, needs to be more on how (diaspora) political actors manage to 'reify and reproduce in a transnational and politicized form a particular identity category - whether that be national, ethnic, secretarian, or religious' (Adamson 2008: 2), and how that is used to mobilise diaspora members for political purposes. In this sense, it is important not to take the relationship between a critical event and diaspora mobilisation, or diaspora mobilisation and transnational participation, at face value, as an implication of lingering loyalties towards the 'homeland', as a manifestation of ethnic identities, or even as a lack of integration into the host society. Instead, it might be more fruitful to examine how some critical events become important, how they are portrayed, narrated and linked to past events and future political projects by diaspora political actors, and what meanings individuals assign to their transnational participation that might follow thereafter.

\section{What about the national context?}

Even in transnational social spaces, place continues to count.

(Kivisto 2001: 571) 
Going back to the question of methodological nationalism and transnationalism, what analytical lens would best suit to understand the contextual factors that shape the mobilisation processes and the forms that transnational political action towards the 'homeland' takes? In other words, how does the national context shape how diaspora members and their descendants mobilise, create social and political networks and maintain ties between different places?

As stated earlier, diasporas mobilisation and transnational political participation have been considered to be dependent on both the host country and the homeland context. Drawing from the social movements literature, one major factor structuring the possibilities for diasporas to mobilise and to participate in homeland affairs is perceived to be both the 'homeland' and host society political and institutional opportunity structures (see Baser 2016: $28-31$; Koopmans \& Statham 2003). They are employed to refer to diasporans' legal, political and social rights, citizenship laws and policies concerning education, welfare, housing and labour (Ireland 1994: 10). Later approaches have included a focus on cultural and institutional aspects, citizenship and discursive opportunity structures (Koopmans 2004). The latter refer to the possibilities of diasporans to diffuse their messages in the public sphere and possibly into public discourses, and to raise support for their political projects. Institutional (namely legal) and discursive opportunity structures can become quite restricted to certain political movements or factions in diasporas that have become criminalised quite often by the pressure exercised by the sending state (see Baser 2014). Relatedly, the bilateral and diplomatic relations between the host state and the sending state are also a factor shaping diaspora actors' possibilities to engage in transnational political action (Baser 2014).

However, trying to capture the significance of the national context is not as clear cut as the division between the host society and 'homeland' would suggest. We need to include in the analysis of diaspora mobilisations not only events that take place in the homeland context but also those in the host country context 
(Baser 2014, 2015a; Baser \& Swain 2011; Østergaard-Nielsen 2001, 2003). For instance, Baser (2015a) argues that diaspora mobilisation can also take place as a result of political developments in the host country, not only in the 'homeland'. One such example is the assassination of three Kurdish political actors in Paris in 2013, which generated mobilisation among the Kurdish communities in the country (and beyond) (Karagöz 2017). As discussed earlier, the strategic framing of certain critical events that resonate with diaspora members, particularly in ways that make reference to a sense of collective belonging or the ones that are emotionally laden, can be a particularly efficient means for mobilisation (Adamson 2013). In other words, homeland-host country dynamics can become conflated via critical events that touch upon both the host country and the 'homeland', and as a result motivate diasporans to mobilise, and not merely towards the 'homeland' but also towards the local policymakers.

Furthermore, the national context in the sending region can vary greatly, as is the case with Kurdistan. The national spaces of different Kurdish societies offer different means (and possibly motivations) to take part in long-distance political projects. 'Homeland'-diaspora relations also shape political mobilisation processes and the diaspora's possibilities to exercise an impact in the 'homeland' context. Not all diaspora contributions are welcomed, and they can sometimes even be met with hostility (Emanuelsson 2008; Hautaniemi, Juntunen, \& Sato 2013). The 'homeland' can also have very different policies towards different sections of its diaspora communities and provide different political opportunities (partial citizenship, legal rights, incentives to return etc.) for diaspora members to take part in homeland affairs (see Levitt \& Glick Schiller 2004: 1023-1024).

In a sense, there is no denying that the national context matters. The host society and 'homeland' institutional, discursive, legal and political opportunity structures, integration and citizenship regimes, citizenship status, bilateral relations between them, and diaspora-'homeland' relations inform diasporas' mobilisation processes and means to take part in the 'homeland' political 
sphere. Making a clear-cut distinction between the two national contexts can leave significant cross-border processes unnoticed. But how the national context matters is a different story. The fact that host society and 'homeland' dynamics can become conflated through a series of events touching both argues against such an analytical distinction between the two national contexts. In this sense, it is possible to distinguish some national particularities and dynamics in how diasporas mobilise (Baser 2012; ØstergaardNielsen 2005; Mügge 2010). It is equally important to pay attention to cross-border processes and how those shape more locally organised political action by diaspora communities.

\section{The transnational context}

What is the role of the transnational context and what explanatory power can it have to understand diaspora participation towards the homeland and the related mobilisation processes? How can we account for the transnational dimension of diaspora mobilisation?

Insights from studies on social movements have been applied to understand diaspora mobilisations and factors shaping such mobilisations through three aspects. These are political opportunity structures, as discussed earlier, the role of resources (organisational and network structures) and the framing of mobilising events (Quinsaat 2013, 2019; Sökefeld 2006). All three evoke what scholars have named the transnational space, in which diasporas formulate and mobilise action (Østergaard-Nielsen 2003). In terms of diaspora mobilisation, transnational space is understood to refer to the social space that extends across national borders, and which entails cross-border activities, engagements, mobility, social relations and emotional attachments that diaspora groups sustain and forge within the host country, towards the homeland as well as towards the same diaspora communities settled elsewhere (Toivanen \& Baser 2020).

The transnational space can provide diaspora members with mobilising structures to engage in diaspora organisations' transnational activities, including the means to participate in diaspora politics. In this transnational character, it can be said, also 
lies their power and potential for diasporas' social and political organisation and mobilisation (Wahlbeck 1999). The transnational opportunity structures play a role in ways diaspora communities participate in homeland affairs and how they mobilise beyond national borders (Koopmans \& Statham 2003; Nell 2008). Østergaard-Nielsen argued as early as 2003 that there is a need to move beyond the nation-state-centred focus of examining the significance of different opportunity structures to diasporas' mobilisation and transnational participation. Instead, she suggested looking at transnational opportunity structures to better reflect the transnational space in which diasporans operate.

Chaudhary and Moss (2016: 7) distinguish between three types of transnational political action that immigrants engage in, and which can be to some degree extended to diaspora members in a more general way (including the second generation): electoral (voting, campaigning, campaign fundraising), organisational (advocacy groups, ethnic associations, charities, hometown associations, ruling party/opposition organisations) and noninstitutional (protests, demonstrations, boycotts, petitions, covert actions, armed conflicts, revolution). They suggest a triadic political opportunity approach to conceptualising how the host country, the home country and transnational political contexts shape such transnational political action, and how such spaces can facilitate and/or limit it. In terms of the political opportunity structures (POS), they distinguish between three key dimensions (2016: 8):

- Receiving country POS: Immigrant integration policies (residency, citizenship); access to receiving country local/national politics; co-development policies/initiatives

- Origin country POS: Governing authority type (autocracy/ democracy); relative stability (conflict, post-conflict, economic/ political crises, natural disasters)

- Transnational POS: Supranational organisations/institutions (UN, ICC etc.); international legal regimes (human rights law); origin and receiving country bilateral relations; foreign policy, geopolitical relations 
This also provides a good starting point to distinguish different types of transnational political action and how different transnational political opportunity structures shape them. Furthermore, as well as considering the transnational and more global context, we also need to pay attention to the more locally based political and social hierarchies that shape mobilisation processes and possibilities to engage in transnational political actions. In other words, whereas the national context remains significant, our lived experiences and possibilities for action are also shaped by the more locally woven set of circumstances at the level of regions, cities or even neighbourhoods (Anthias 2012). One example of this is the networks, which can be quite local, as discussed later. The significance of locality applies also to the sending region.

Yet, it would be misleading to consider all diasporans' lives and experiences automatically to be transnational, and those of 'natives' or those left behind in the 'homeland' as sedentary and nationally focused. Diasporans take part in transnational practices to very different degrees and even live out different forms of transnationalism, as is suggested by Dahinden (2009). Also, Anthias (2012) observes the need to take into account that all people, regardless of their migration trajectories or origins, inhabit transnational spaces in the global world. She distinguishes between 'transethnic' relations and 'transnational' relations, the former referring to relations between ethnically constructed groups and their similar experiences, goals and trajectories. I return to this discussion in the analysis chapter but, for purposes of clarity, I have chosen to employ the term 'transnational' as it is commonly employed in the migration literature.

In addition to looking at different opportunity structures in the host country, the homeland context and transnationally, it needs to be considered that they and the related mechanisms of inclusion/ exclusion and hierarchies also intertwine at the transnational and national levels. For instance, Anthias (2012) argues for adopting a new imaginary to study the complexity of mobilities, and she suggestsdoingthis through thetranslocationalframe. Shewarnsagainst polarisation between national and transnational perspectives 
by suggesting that the transnational perspective ought to move past a focus on the relations between nations and nationally based social hierarchies and take into consideration social hierarchies on a global level. However, for Anthias (2012: 103) this does not entail ruling out the national lens, 'since it possesses important affective, discursive, experiential and political relations within a global context'. The similar line of reasoning can be used to look at different social and political hierarchies and power structures in the form of political, institutional, legal and discursive opportunity structures, the mechanisms of inclusion and exclusion they produce and how those intertwine at the transnational, national and local levels, as discussed in Chapter 5.

\subsection{The Second Generation}

\subsubsection{Transnational lives and participation}

One of the most pertinent questions in transnational studies from the generational perspective seems to be whether transnational ties and loyalties still matter beyond the first generation, the actual migrants. There is an abundant literature on how migrants' children engage in cross-border activities and networks that are directed to the sending region of their parents. Some scholars have suggested that the children of first-generation migrants express fading interest towards their parents' countries of departure (Kasinitz et al. 2002; Portes \& Rumbaut 2001; Portes \& Zhou 1993; Waldinger 2015), ${ }^{8}$ whereas others have argued that secondgeneration members continue to engage transnationally (Baser 2012, 2014; Lee 2008, 2011; Levitt 2009; Levitt \& Glick Schiller 2004; Levitt \& Jarowsky 2007; Levitt \& Waters 2006; Mügge 2010; Somerville 2008; Toivanen 2014), albeit to a lesser degree and possibly in different ways compared to their parents. Can we make sense of second-generation members' actions, attachments, identities, mobilities, relations and networks through the transnational frame? 
Whereas the earlier migration literature on transnationalism focused on the so-called first generation, later on a number of scholars argued that transnational theorisation can also be useful to understand the lived experiences of the second generation (see Levitt 2009; Levitt \& Glick Schiller 2004). What this means concretely is that second-generation members are embedded in a social space that includes frequent references to the 'homeland', and thus can be informed by the current events in their parents' society of departure. They can also make frequent visits to their parents' 'homeland' (Cressey 2006), maintain contacts with relatives still living there, and be involved in the political and social organisation of the diaspora community to which they belong. Albeit in a different manner to their parents, second-generation members in this study continued to maintain transnational relations, ties and attachments towards the Kurdistan region (and not limited to it) and some did even opt to temporarily 'return' to Kurdistan. This transnational space shaped their everyday life, as they had been raised in a setting where the 'homeland is referenced daily - ideologically, materially, and affectively' (Levitt 2009: 1231).

There is evidence on how diaspora mobilisation can lead to increased transnational mobilisation activities among the second generation. For instance, there was increased participation in transnational activities among both the first and second generations in the Arab diaspora communities in Europe during the socalled Arab Spring (see Moss 2016; Premazzi et al. 2013). Another example was witnessed during the Gezi Park protests that took place at Taksim Square, Istanbul, in May-June 2013. It soon resonated among the diaspora communities settled in Europe, sparking demonstrations including second-generation members in Sweden, the Netherlands, France and Germany (Baser 2015b). Similarly, Hess and Korf (2014) show how second-generation Tamils in Switzerland became mobilised during the final battle of the civil war in Sri Lanka in 2009. These studies also illustrate how political socialisation processes can be quite different for the first and second generations. The first-generation members 
can have more direct links to 'homeland' political actors and diaspora organisations that are directly affiliated to them, whereas the second-generation members can be more familiar with local activist spheres and movements (Karagöz 2017). Compared to their parents, they are also most likely more familiar with the political, institutional and other opportunity structures (and their limits) in the host society, through their citizenship status and socialisation within their societies of birth (Baser 2016).

Second-generation members' transnational political participation can be located and directed at the host society, the 'homeland', simultaneously to both or even towards the transnational diaspora community. The transnational space, to some extent, provides second-generation members with mobilising structures to engage in diaspora organisations' transnational activities, including the means to participate in diaspora politics, but it can have more local manifestations concerning the second generation. Hess and Korf's (2014) study on second-generation Tamils shows that they became sensitised to the conflict in Sri Lanka through direct contact with relatives and (diaspora) political discourses of suffering circulating in the transnational space. However, the authors argue that their activism was located in and directed towards the host society, with the aim of raising awareness of the plight of Tamils back 'home' and of prompting Switzerland to take action at the international level.

One line of discussion on diasporas' transnationalism has been the need to incorporate a focus on the virtual dimension of diasporans' and diaspora organisations' transnational political involvement (Bailey, Georgiou, \& Harindranath 2007; Brinkerhoff 2009; Candidatu, Leurs, \& Ponzanesi 2019; Kissau 2012; Kissau \& Hunger 2010). Examples of diaspora members' online activism have become visible in the wake of the so-called Arab Spring and in the aftermath of the political upheavals that have occurred in Cairo, Tunis, Beirut, Erbil and Istanbul, among other cities (Baser 2015a; Beaugrand \& Geisser 2016; Premazzi et al. 2013). Scholars in media studies have also increasingly paid attention to the second generation (Georgiou \& Ponte 2013). However, the emphasis 
has been more on transnational cultural or familial ties instead of politically orientated engagement, with a few exceptions (Costa \& Alinejad 2020; Müller-Funk 2020).

Also, focusing on the virtual dimension of diaspora transnationalism does not mean ignoring the national context altogether. Indeed, Van de Bos and Nell (2006) show in their study how the Internet usage of Iranian and Turkish Kurdish migrants in the Netherlands is shaped by offline community networks and states' borders. In other words, they conclude that the new media and transnationalism do not automatically 'broaden or dissolve geographical identity and connectivity, but may reinforce it' (p. 201) and that territoriality continues to play a role in digital practices. Furthermore, their study shows that, whereas the first-generation migrants' online practices reflect their offline networks, the second generation forms more sovereign online communities that pivot on their hyphenated identities.

The technological developments have opened new venues for mobilising practices and for participation in homeland development. This is particularly visible in terms of economic remittances, that is, money transfers to the sending region, but also in terms of what has been named social remittances (transfer of ideas and practices) and political remittances (long-distance voting, for instance). Also, well-settled members of the second generation in their societies of birth can resort to technological means to be(come) active through different forms of transnational political activities 'at distance' - both physically and virtually. Keeping in touch with relatives back home and following the 'homeland' events, for instance via Facebook and Twitter feeds, has never been easier.

Acknowledging the transnational diaspora space is important to defy more methodologically nationalist interpretations of 'return' migration between the host society and 'homeland'. At times, diasporans' return migration can be motivated to take part in the societal development in the sending state and a form of diasporic homecoming, or they can be motivated by strategic reasons, for the accumulation of educational or professional skills or for 
investment purposes (Baser \& Toivanen 2018a). More recent studies have shown that members of the second generation may also 'return' to their parents' country of departure (King \& Christou 2014; Potter 2005; Teerling 2011). However, second-generation return seems to be more often approached from the perspective of identity and belonging, and more rarely in terms of diaspora contributions. This is also more generally the case with the second generation's transnational participation towards the ancestral 'homeland' through various forms of (transnational) offline and online activities that aim to contribute to or have an impact on their parents' society of departure. Relatedly, diaspora politics, that is, long-distance political transnational ties and engagements towards the 'homeland', have been signed off as something that concerns diaspora communities' second generation less than their parents. This has also been the assumption with mobilisation processes. True, the second generation might be less inclined to take part in 'homeland'-diaspora politics - at least in a manner similar to their parents. Also, their lived experiences - potentially very different from those of their parents - shape their transnational (political) ties and actions, and what kind of identities and politics of belonging are related to such engagements.

Indeed, the observations on second-generation members' transnational ties have been accompanied by calls to incorporate a focus on the generational dynamics of diaspora experiences and more specifically on transnational diaspora politics (Alinia \& Eliassi 2014; Baser 2015a; Emanuelsson 2008). Alinia and Eliassi (2014) suggest that there are significant differences between the Kurdish first and second generations that require adopting different theoretical and analytical conceptualisations - for instance in terms of transnational political participation. In other words, this does not automatically mean that the members of the second generation would be less political per se but that their (transnational) political participation might manifest itself in different ways compared to that of their parents. Perhaps the question that would need to be asked is: how can second-generation members' mobilisation and transnational participation be conceptualised so 
that the analytical concepts would reflect their experiences and meaning-making processes, without the residual meanings of earlier conceptualisations employed to understand their parents' transnational (political) participation? For instance, what exactly is diasporic in second-generation transnationalism?

\subsubsection{Beyond diasporic?}

\section{Diasporic circulation}

There is no denying that the transnational frame can allow a better understanding of the political and social organisation of migrant communities and the cross-border relations, ties and activities of their members towards the sending region - provided that the communities are not understood as homogeneous and static entities (Brubaker 2002). Also, the transnational social space in the context of diaspora movements can offer, assign value to, and devalue collective narratives for the younger generations and possibly inform them about linguistic and cultural matters related to the societies of departure. However, whether subsequent generations can be considered and even conceptualised within the more classical understanding of diaspora is highly debatable. Or, as Wahlbeck (1999) notes, Kurdish communities in exile can, indeed, be considered to constitute a diaspora, but whether this is going to remain the case for subsequent generations of Kurds remains an open question.

So, in the light of these reflections, what are we to make of secondgeneration members' stories in this study? We can approach their transnational engagements and actions as well as mobilities as diasporic in the sense that they - at least to some extent - are connected to them having been raised in the transnational Kurdish diaspora space. Drawing from the same material as for this study, I have discussed the resources that are available to secondgeneration Kurds as a result of their parents' migration process and transnational ties elsewhere (Toivanen 2019). That article focused on the role of mobilisable resources and concluded that they were 
capitalised upon by second-generation members for two, albeit interrelated, aims: to advance one's educational and professional advantages and to contribute to the development of Kurdistan.

In terms of activities, I suggest that second-generation members can take part in what could be called diasporic circulation. By 'diasporic circulation' I refer to transnational engagements and actions through which individuals aim to improve the conditions in the sending region either at distance (both online and offline) or en lieu. Such actions can take place via institutional or noninstitutional means, and include temporal migration and shortterm visits; economic, social and 'political' remittances (such as long-distance voting); lobbying; providing logistical support in times of political disturbance; and online political activism such as blogging, campaigns to raise awareness and so forth. For instance, respondents took part in diasporic circulation towards the Kurdish regions as outlined above, in a way that was underlined by their motivation to transmit knowledge and immaterial sources towards the region. Some also engaged in transnational circular mobility between France and Kurdistan, which can be understood as part of their diasporic circulation, in contrast to others' 'voluntary immobility' to stay put in France (see de Haas \& Rodríguez 2010). The actions are specifically enabled by pre-existing networks, family ties or associative structures that second-generation members have access to as a result of their parents' migration, hence the attribute diasporic. The transnational actions and engagements can also be approached as a form of diasporic circulation, particularly when they aim at improving the conditions in the sending region. However, it would be too straightforward to conclude that the meanings attached to such transnational activities are also and only - by definition diasporic.

\section{On identity}

In particular, there is risk of reducing and essentialising secondgeneration members' transnational participation, including that of political character (and mobilisation that might precede it) and to treat it automatically as an indicator of diasporic belonging, 
or as a reflection of their assumed 'ethnic' identity. Approaching transnationalism and mobilisations merely as identity-driven phenomena would mean failing to acknowledge the heterogeneity of individuals' motivations to engage in 'homeland' affairs, but also to increase the risk of falling into methodologically nationalist interpretations of such motivations. Second-generation transnational engagements can also have a strategic and practical dimension and be more a question of access than of having emotional significance. For instance, Santelli and colleagues' study on secondgeneration Algerians in France (1999) show that investment opportunities can motivate the sustaining of transnational ties to the homeland without such activities necessarily being rooted to lingering attachments and loyalties towards the homeland. I have also discussed the professional and educational reasons underlying second-generation Kurds' temporary 'return' motivations elsewhere (Toivanen 2019).

On the other hand, the identity component should not be altogether dismissed. The question is how to account for it. As Hess and Korf (2014) show in their study on second-generation Tamils in Switzerland, their mobilisation took place in relation to their identities as Swiss, not as Tamils. They suggest that it was also the second-generation's identity as Swiss that became mobilised against the perceived passivity and ignorance of the Swiss government to act in the crisis facing the Tamils. Also, the reasons for mobilisation and the motivations to engage in transnational participation are not necessarily a question of either/or for all members of the same generation. Fokkema and colleagues (2013) have shown that second-generation members whose parents came from Morocco, the former Yugoslavia and Turkey engage in sending economic remittances to their parents' societies of departure for two main reasons - either for the emotional attachments that they foster towards their parents' countries of origin or for reasons of self-interest, for instance to ensure the managing of their investments and material assets in the event of 'return'. This also speaks volumes of the heterogeneity within diaspora communities (namely in terms of age, gender, class, generation, sociopolitical 
status and so forth) and of the need to account for such factors when looking at why some individuals become mobilised and transnationally engaged towards the 'homeland' whereas others do not (Fiddian-Qasmiyeh 2013).

The complexity of the identity question was also illustrated in respondents' stories. We can see how the transnational space had shaped their lived experiences and decision-making processes about transnational participation. In this sense, the diaspora context, if approached in the sense of a transnational social space that informs, facilitates and shapes mobilities, engagements, participation, action and possibly even attachments, is relevant to consider even beyond the first generation. What is more, not only did some plan to return to Kurdistan by employing the existing diaspora networks they had but in some cases those led to the creation of new networks. In that sense, their transnational mobility did not only lean on the pre-existing (diaspora) networks or institutional structures but instead led to a creation of a new one that was not diasporic per se (Toivanen 2019). Discerning what is diasporic in second-generation mobilisation processes and transnational participation towards the ancestral 'homeland' opens unavoidably the question of what is not. This urges us to ask: can we deduct second-generation transnationalism and mobilisation as being automatically and only as diasporic or is it also something else? This question is tackled in Chapters 6 and 7. 
PART II

\section{Here and There: Between Kurdistan and Europe}



CHAPTER 3

\section{The Kurdish Case}

\subsection{Introduction}

Descriptions of Kurdistan and the Kurds quite often begin with the observation that the Kurds are the world's biggest nation without a state. To date, no state of Kurdistan with internationally recognised borders has existed. So where is Kurdistan located, then, and who are the Kurds, the world's largest people without a state? How have the histories of Kurdish societies been shaped in Iraq, Turkey and Syria? And how does the historical division of Kurdistan affect the current state of affairs in the region? This part of the book consists of a brief overview and contextualisation of the historical background of Kurdistan and the Kurds in the Middle East. This chapter focuses on the situation of Kurds in Iraq, Syria and Turkey (with the exception of Iran), since the research participants originate from these regions. ${ }^{9}$

\subsection{Who Are the Kurds?}

The region of Kurdistan is usually employed to refer to a land area with large Kurdish-speaking populations stretching over Turkey, Iraq, Iran and Syria, mainly, and with smaller territories in western and central Asia, as shown in Map 1. The land area comprises approximately 518,000 square kilometres, which is roughly equivalent to the area of France. More precisely, the Kurdish populations 


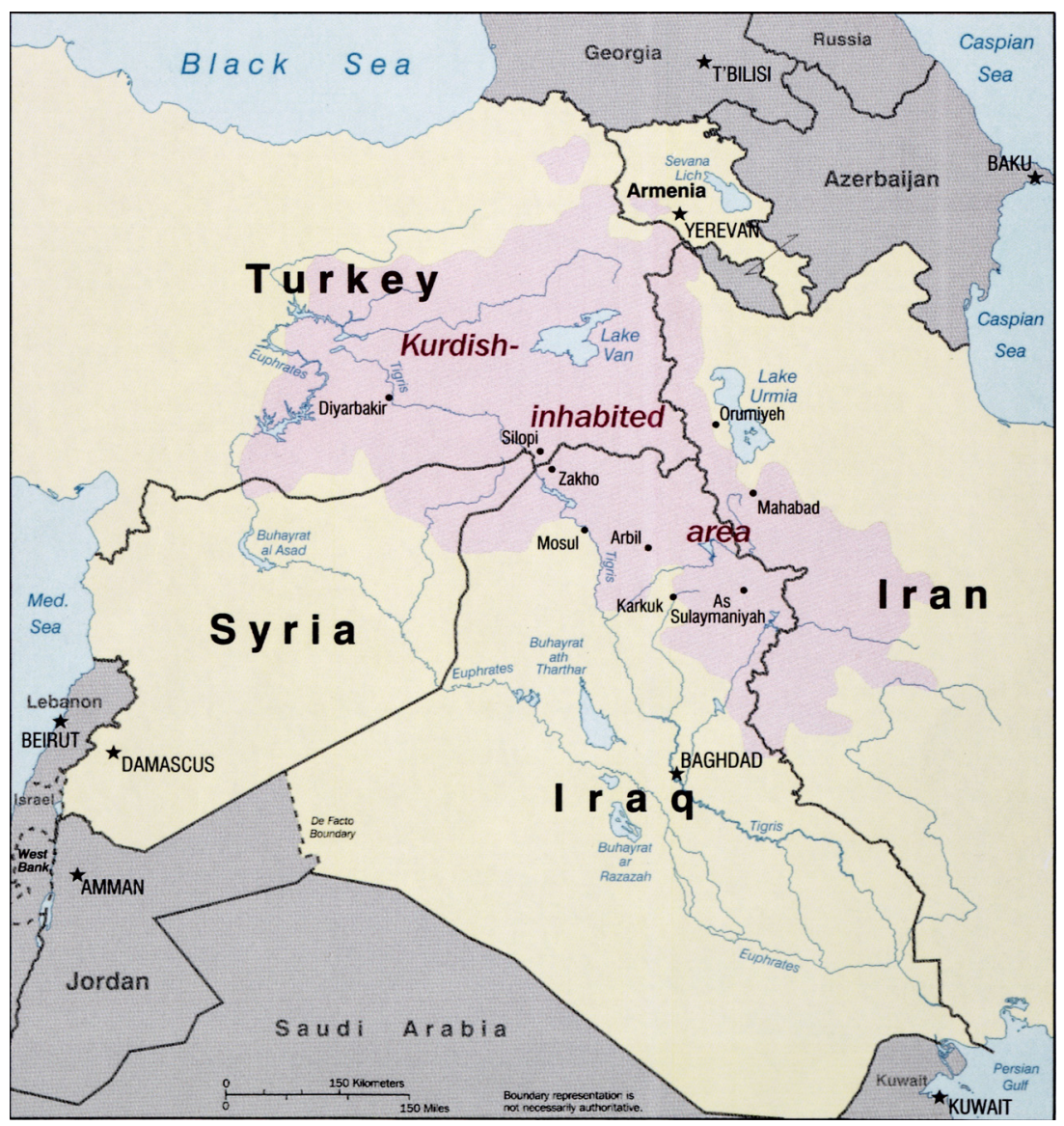

Map 1: The Kurdish-inhabited area. Source: Library of Congress, Geography and Map Division.

reside in quite extensive areas of eastern Turkey, northern Iraq, western Iran and northern Syria, and they form the fourth largest ethnic group in the region after Arabs, Persians, and Turks, consequently constituting rather sizeable ethnic and linguistic minorities within these four states. The estimated number of Kurds varies between 25 and 30 million (Gunter 2011: 3-4; Hassanpour \& Mojab 2005: 214; McDowall 1996), and the numbers are unequally divided, with Turkey having the largest Kurdish-speaking population, followed by Iran, Iraq and Syria. In addition, many Kurds have settled outside Kurdistan. For instance, Istanbul hosts 
approximately three million Kurds and therefore can be said to be 'the biggest Kurdish city.' ${ }^{10}$

Who, then, are the Kurds? Tracing the history of the Kurds is a fairly complex matter. It is suggested that the majority of Kurds are most likely descended from heterogeneous Indo-European tribes that moved westward across Iran around the middle of the second millennium bc (McDowall 1996: 8). The first historical references to 'Kurdistan' as a geographical term date back to the 12th century (ibid., 6, 13). During the Ottoman period, 'Kurdistan' was used to name the province of Diyarbakir, in today's eastern Turkey, and a province called Kordestan still exists in today's Iran (van Bruinessen 1992: 11). Kurdistan, 'the land of the Kurds', nowadays refers to a land area of mountainous and plateau regions that consists of the north-west Zagros and the eastern Taurus mountain ranges.

Today Kurds form a rather diverse group in terms of language, religion and political affiliation. They live in both urban and rural areas, either in the Kurdistan region, outside it in Istanbul, Baghdad or even Teheran, or in diaspora communities outside the Middle East (Taucher, Vogl, \& Webinger 2015). The Kurdish language can be considered one distinctive feature of 'Kurdishness', although it is not a straightforward issue. The Kurdish language belongs to the Indo-Iranian group of Indo-European languages and is related to neither Arabic nor Turkish. However, the language has four dialect groups (Kurmanji, Sorani, Zaza/Dimili, and Hawrami/ Gorani), which can be quite different one from another. Unlike the case with most nation-states around the globe, there exists no clear Kurdish language or dialect boundaries that would follow any state's borders. ${ }^{11}$ However, the two most commonly used dialects of Kurdish are Kurmanji and Sorani, in that order. Kurmanji is mostly spoken in Turkish Kurdistan (with Zaza too being spoken in this region) and Sorani in Iraqi and Iranian Kurdistan (where the Gorani dialect is also widely spoken). The two main dialects also differ in their alphabets, Kurmanji using the Latin script and Sorani the Arabic script, with minor modifications (Sheyholislami 2010). As a matter of fact, it has been said that Kurmanji and Sorani are grammatically as different as the English and German 
languages are and that the differences in vocabulary are comparable to those between Dutch and German (McDowall 1996: 9).

To make matters more complex, the Kurds, who live in Syria, Iraq, Iran and Turkey, tend to be at least bilingual, speaking Kurdish and the official language of the country they live in. This is perhaps most noticeable in Turkey, where, because of strict assimilation policies and the prohibition of the Kurdish language until the 1990s, many Kurds nowadays speak mostly Turkish. In Iran, the situation is a bit different. The official language, Farsi, is used in public, while Kurdish seems to be spoken mostly in the private sphere. The Kurdish language and its usage, in contrast to Turkey, has never been criminalised in the country, but it does not enjoy any minority language status either. The situation in Iraqi Kurdistan is by far the best when it comes to Kurdish language rights. In fact, for some time now, there has been a lively debate on the standardisation of Kurdish and whether the official version of Kurdish should be the Sorani or instead the Kurmanji dialect (see Hassanpour 2012). ${ }^{12}$ In Syrian Kurdistan, Kurdish, alongside Arabic and Assyrian, has been the language of education since 2016. ${ }^{13}$ During the latter part of the 20th century and the Baathist rule, the language education was in Arabic and Kurdish-language education was often carried out secretly in private homes.

Religion is another element that highlights Kurds' heterogeneity. Martin van Bruinessen (1999a) has suggested that Islam has greatly influenced the Kurdish societies and that it has a distinctive character in Kurdistan. However, religion has almost never been a common denominator for identification as Kurds, and a collective sense of 'Kurdishness' does not seem to have its basis in shared religion (ibid.). Religious minorities among Kurds include Fayli, Jewish, Christian and Alevi, as well as the Yezidi Kurds, who became sadly famous after the Sinjar massacre and the abduction of Yezidi women, who were then sold into slavery in 2014. Van Bruinessen also argues that the Kurdish politics and societies have become more Islamic, although simultaneously the ethnonational sentiments have brought about distinctive Kurdish identities within the Islamic movements. Religious affiliations (and ethnicity) 
have also structured the political memberships for Kurdishspeaking minorities in Turkey, Iran and Iraq, as I will discuss later.

The 'Kurdish issue' has since the very beginning of the 20th century been a cross-border issue, and it remains so. The cross-border character of the 'Kurdish issue' and the formation of Kurdish identities both in Kurdistan and in diaspora continue to be informed by the 'state of statelessness' of Kurdistan. This transnational or cross-border nature of Kurdistan is reflected in the understandings of 'Kurdishness'. Or, as Kerim Yildiz (2007: 82) puts it,

There is no single Kurdish identity, but there are Kurdish identities that defy or transcend borders. Pan-regional relations between the Kurds have always been complex and intimate. The mountain ranges that mark frontiers between nations do not mark breaks in linguistic, cultural or familial continuity.

In sum, we can say that, regardless of the nation-states' frontiers that cut across Kurdistan, Kurdish identities are rooted to attributes such as the Kurdish language (see Kreyenbroek 1991), shared ancestry and myths of origin and the common land of Kurdistan (McDowall 1996: 4-5). On the other hand, there are quite considerable differences in the idea of a pan-Kurdish nation and clear differences in attachments to tribal, national and religious identities above one's ethnic identity as Kurdish (ibid.: 1). ${ }^{14}$

Kurdish ethnic identities and a sense of 'Kurdishness', or Kurdayet $\hat{\imath}$, have been formed in relation to various nation-states' political spaces and the minority-majority relations within such states. Denise Natali (2005, xviii) suggests that being 'Kurdish' ought to be considered in relation to what it means to be a citizen of Iraq, Turkey or Iran. Abbas Vali (1998: 84) further argues that the Kurds share mutual experiences of 'otherness' within various nationstates, which has become a shared attribute to understandings of 'Kurdishness' across the region. Meanwhile, the new emerging societal and political constellations in the Kurdish societies in Syria, Iraq and Turkey, specifically, are introducing new dynamics to the construction of Kurdish identities. Before discussing the 
current situation, I will first take a closer look at the division of Kurdistan into Iraq, Syria and Turkey from a historical perspective and the related majority-minority relations in these respective countries. The following section offers an overview of how Kurdish identities and politics have been formulated within the nation-states of Iraq, Turkey and Syria in the 20th century.

\subsection{Kurdistan Divided - Historical Tour d'Horizon}

The state of statelessness of Kurdistan is a major factor structuring Kurdish politics both in Kurdistan and in diaspora. Two major historical developments have been particularly significant in terms of the division of Kurdish lands. The first dates back centuries to the Ottoman and Persian empires. Indeed, the borders between Iran, Turkey and Iraq, where large Kurdish majorities today reside, are roughly consistent with the treaty between the Ottoman and Persian empires in 1639, which divided Kurdistan into Ottoman and Iranian zones. The region of Kurdistan was situated between the Ottoman and the Persian empires from the 17th century till the early 20th century, when it, alongside Armenia, was the empires' battlefield until the First World War (Hassanpour \& Mojab 2005: 215-216).

However, the border that had lain between the two empires became officially fixed only in the early 20th century. This was the time when modernist Western ideas of 'territorial integrity', that is, the indivisibility of the nation-states, and colonial desires swooped over the region. The subjects of pre-modern states, including the Kurds, had remained more or less attached to the land and tribal affiliations (ibid.), before ideas of a Kurdish state and 'homeland' started to emerge in the early 20th century. In the wake of the downfall of the Ottoman Empire and in consequence of the treaties signed by colonial powers, Kurdistan was allocated to the political spaces of Turkey, Iraq, Iran and Syria. This division was in a sense 'cemented' by a series of treaties in the early 20th century that set the nation-states' boundaries in the Middle East for the decades to come. 
After the fall of the Ottoman Empire during the First World War, the French and the British negotiated a secret document, now known as the Sykes-Picot Agreement, to divide the Levant region into two spheres of influence (Gunter 2009: 196). Building new political entities on the carcass of the Ottoman Empire, the treaty gave birth to modern Middle Eastern states as they are more or less known today. The agreement was signed into law by the Treaty of Sèvres in 1920. As a matter of fact, it included a provision for a Kurdish state, which, to the widespread disappointment of the Kurds, was soon replaced in 1923 by the Treaty of Lausanne. This was based on an agreement between the Allied forces and the Turkish state. The former recognised the Turkish state sovereignty and its borders, thus cementing the notion of Turkey as an indivisible state and Turkey renounced any claims it had to the remainder of the Ottoman Empire (ibid.: 125). Hence, the treaty established the borders of modern-day Turkey and left the Kurds with a minority status in their respective countries for decades to come.

These two treaties are frequently mentioned as the sources of disappointment and sentiment of betrayal of Kurds by the Western powers, and still referenced today by Kurdish politicians (namely in Iraqi Kurdistan) as well as political activists in diaspora. As a result of these treaties, the unofficial borders of Kurdistan still cut through the middle of geopolitical power centres, where the borders of the current nation-states of Iraq, Iran, Turkey and Syria meet (McDowall 1996: 5-6). The formation of Kurdish societies and the related identities in the region have since the very beginning of the 20th century been informed by multiple political spaces and the related forms of inclusion/ exclusion that have been formulated within those spaces. The historical division of Kurdish-inhabited regions and the continuous state of statelessness today continue to shape and inform Kurdish politics, both in Kurdistan and in the diaspora. The history of majority-minority relations concerning Kurds in three national contexts, Turkey, Syria and Iraq, will therefore be the focus of the next sections. 


\subsubsection{Kurds in Turkey}

The Kurds were incorporated into the Ottoman Empire as early as the 16th century. As Klein (2015:9) notes, the notion of Kurds as 'a people divided and Kurdistan as the battleground on which the wars between others were fought, with Kurds caught in the middle' was cemented in the subsequent centuries. The 19th century saw the emergence of national thinking and the concept of statelessness gradually shaped the understanding of Kurdish identity that also became more clearly distinguished from Armenian and Turkish national identities (ibid.: 15-16). A major event shaping minority-majority relations in Turkey was the establishment of the Turkish republic in 1923, when the Turkish provinces of the Ottoman Empire became independent and formed the Turkish state. In the Ottoman Empire before the First World War, Islam was considered the primary component of Turkish national identity (Ergil 2007: 265-269), which meant that expressions of Kurdish ethnic identity were more or less tolerated. This was also partially the case during the transition era in Turkey's journey toward becoming a modern state.

This gradually changed in the new republican period. The Kemalist project of nation-building was led by Mustafa Kemal, or Atatürk, as he became known in 1934. It aimed to centralise power and to unify various provinces by bringing the diverse populations together through secularised, modern and unified state nationalism (Insel 2007). The political space of the Kemalist Turkey did not accommodate ethnic minority identities or the expression of them, and the republican state had clear boundaries of ethnic belonging based on common 'Turkishness'. During the republican period, the Kurdish regions were militarised, the Kurdish language prohibited, Kurdish cultural activities banned, Kurdish activists arrested and deported, and several Kurdish deputies were replaced (Natali 2005: 82-83). These drastic nation-state-building measures resulted in the ethnicisation of the political space, and subsequently to the growth of Kurdish national movements in the decades to follow. Atatürk's harsh policies of secularising 
Turkish society led to a construction of otherness that was based on both ethnicity and religion, ${ }^{15}$ and, consequently, some Kurdish nationalists resorted to forms of ethno-religious nationalism (ibid.).

As the 1970s were ushered in, the emergence of legal left-wing organisations affected the 'leftisation' of Kurdish identity, but, towards the end of the decade, Kurds started to move away from the Turkish leftist parties and join nationalist Kurdish groups, which became criminalised (Gunes \& Zeydanlioğlu 2014: 1-6). The Kurdistan Workers' Party (PKK), which is probably the best-known Kurdish political movement, was established in 1974. This brought more instability to the border regions as the state embarked on scorch-and-burn tactics that left Kurdish villages and populations seriously harmed (Human Rights Watch 1991).

Finally, the coup d'état in 1980 by Turkish military officers brought Turkish nationalists into power and closed the political space to opposition groups (Ergil 2007: 270). Denying the existence of its Kurdish population, the Turkish state went beyond refusing the Kurds their cultural and linguistic rights. For instance, General Kenan Evren famously stated after the military coup:

There is no such thing as Kurd. They are mountain Turks. It is a concept derived from the 'kart-kurt- sounds coming out while our citizens in the southeast are walking on snow. That's why they were referred with that name.

This was the backdrop for the mobilisation of Kurds in Turkey in the 1980s and 1990s (Gunes 2017). Also, the foundational philosophy of the PKK was laid during the previous decade. In 1984 the bloody civil war started between the PKK and the Turkish state that has to date taken the lives of around 30,000 people (UCDP Conflict Encyclopedia ${ }^{16}$ ). The political space and Turkish nationalism were re-Islamised, thus providing more political space to Sunni communities. Nonetheless, the understanding of 'Turkishness' still had its foundations in ethnic premises. For instance, 
questions related to the Kurdish regions were discussed as the 'eastern problem' and Kurds referred to as the 'mountain Turks'. For instance, Welat Zeydanlıoglu $(2008,2012)$ has argued that the Kemalist project aimed at linguistically and culturally 'civilising' and unifying the various minorities by decreasing the influence of religion and primordial identities. He aptly calls this the Turkish version of the 'white man's burden'. The suppression of the Kurdish language has played a key role in this process of 'Turkification' of those perceived as 'backward, tribal Kurds' (ibid.: Uçarlar 2009).

Kurdish identity had become salient in the wake of the government's refusal to grant the Kurds linguistic and cultural rights, while promoting their assimilation to the Turkish state and altogether denying the existence of its Kurdish population. Written and spoken Kurdish was banned, and Kurdish cultural activities were prohibited as early as in 1924. The new constitution in 1982 reinforced the ban on minority languages and prohibited giving one's children Kurdish names. The ban on the Kurdish language was lifted in 1991, but on the same day the Anti-Terror Law (Law 3713) was introduced. That law defined 'terrorism' rather vaguely, thereby allowing the prosecution of individuals who engaged in 'verbal and written propaganda [that] aims to destroy the national unity and the indivisibility of the Turkish Republic' (Zeydanlıoğlu 2012: 112). With this, alongside the penal code, which criminalises 'the denigration of Turkishness' (Article 301), both legal definitions were and continue to be employed against (Kurdish) politicians, journalists, authors, researchers and political activists (Freedomhouse 2008: 16-18). The Turkish state rhetoric constructed the 'Kurdish question' as a case of 'terrorism' in legalistic as well as in other official contexts, which still resonates today.

The end of the last millennium witnessed an event that would shape Kurdish-Turkish relations for years to come. In 1999, one of the founding members of the PKK, Abdullah Öcalan, was arrested by the Turkish National Intelligence Agency (MİT) in Nairobi, Kenya. He had lived in Syria for almost 20 years till 1998, when the regime forced him out under the pressure it received from Turkey. Öcalan has ever since remained imprisoned on Imralı 
island, near Istanbul. Following this, the PKK underwent a profound transformation in the 2000s. Their calls have shifted from establishing a state to demanding a non-state solution, and from engaging in a military struggle towards emphasising a political solution to the decades-long civil war (Akkaya \& Jongerden 2011: 2013). However, in recent years, the situation in Northern Kurdistan has deteriorated at the rupture of the fragile peace negotiations between the PKK and the Turkish state, as I will discuss later.

\subsubsection{Kurds in Syria}

Syria as a political entity came into existence as a result of the Treaty of Sèvres in 1920, when it was allocated to French rule. Historically, the Kurds in Syria have lived in the northern parts of the country, in the border region with Turkey and Iraq. However, they have been fragmented into three principal areas (Kurd Dagh, Kobane and Jazira), a characteristic that is still visible in the form of the three cantons that make up Rojava (Schøtt 2017). This has meant that different Kurdish areas within Syria have also to some extent experienced different minority policies by the Syrian state. Kurdish nationalism was shaped in terms of the creation of the Turkish state, for instance leading to the emergence of the Khoybun League in 1927, which consisted of Kurdish tribal leaders, sheiks and intellectuals (Tejel 2009) protesting the Kemalist rule. The border between Turkey and Syria was not yet officialised and following the Ararat revolt in 1930, led by Kurdish leaders and suppressed by the Turkish military, the Khoybun League turned towards linguistic and cultural activities (ibid.).

The Syrian Republic became independent in 1946, after the Second World War. Soon after, the country 'fell into a period of great political instability and was swung between martial and parliamentary rule by successive coups', as Allsopp notes (2015: 20). In the decades to come, Arab nationalism became the most influential ideology, particularly following the Arab-Israeli War in 1948, the Suez War in 1956 and the Cold War (Tejel 2009). The Kurdish nationalist movement grew again in the 1950s in 
the Jazira region, and Kurdish parties started to be created. Amid the rising Kurdish nationalist movement in a political environment dominated by Arab nationalism, Damascus passed a governmental decree in 1962 that led around 20\% of Syrian Kurds (mainly in Jazira) to lose their citizenship rights (Tejel 2009: 50-51). Defined as aliens, they were deprived of their rights to education, marriage, property ownership and political participation. This also meant that their lands could be handed down to loyal Arabs (Schøtt 2017: 9).

The following year, in 1963, the Ba'athist party came to power through a coup d'état, one month after a similar coup in Iraq. After this, attempts to 'Arabise' the Kurdish population were intensified, with the interdictions to publish, teach or speak Kurdish in schools and workplaces. The regime also Arabised Kurdish place names, conducted arbitrary arrests on Kurdish figures and deleted references to Kurds in history books. Kurdish parties, which had grown out of the first one established in Syria, the Democratic Party of Kurds in Syria (DPKS) in 1957, had internal disagreements over whether the Kurds were a nation or a minority and on what attitude to adopt towards the regime (Allsopp 2015: 84). This changed in the 1980s with the arrival of a new political player.

In the late 1970s, the Kurdistan Workers' Party was established just on the other side of the border. After the 1980 coup d'état in Turkey, the PKK leadership was offered refuge in Syria, where one of its founding members, Abdullah Öcalan, had already been based since 1979. The party gained popular support among young Kurds in Syria (Allsopp 2015: 103), partially because the regime allowed the PKK to mobilise freely, the situation being the exact opposite for old parties. For instance, Tejel (2009: 104105) writes that 'the PKK took over the cultural framing of the Syrian Kurds' as they managed to politicise the expressions of the Kurdish culture, as long as their actions were directed towards Turkey. The PKK has significant presence over Kurdish culture in Syria, particularly in Kobane and Kurd Dagh (Allsopp 2015: 103). The PKK's presence in Syria ended in 1998 when it expelled 
Öcalan out of the country. He was then arrested in Nairobi the following year.

\subsubsection{Kurds in Iraq}

The Treaty of Sèvres, signed by the Allied Powers and the Ottoman government, separated Syria and Iraq from the Ottoman Empire (McDowall 1996: 13). Iraq was actually established by the British from three provinces (vilayets) - Basra, Baghdad and Mosul - putting the Kurdish populations in a state inhabited mainly by Arabic speakers. The treaty that was supposed to grant Kurdistan statehood after the disintegration of the Ottoman Empire never actually materialised and was instead replaced by the Treaty of Lausanne in 1942. The British did give Kurdistan semi-legal political status, and the provisional 1921 Iraqi Constitution stated that two ethnic groups, the Arabs and the Kurds, constituted the state of Iraq (Natali 2005: 27). After 1925, the British attempted to unite the various Iraqi populations (Shi’a Arabs, Sunni Arabs, Sunni Kurds, Shi'a Kurds, Shỉa Persians, Jews, Turkomans and Christians) by constructing a national Iraqi identity based on secular values and a sense of unity. Formal British rule came to an end when Iraq gained quasi-independence from the British crown in 1932. In a similar way to Syria, Arab nationalism emerged, with the promotion of ethnicised pan-Arab identity and Iraqi patriotism.

Most members of the Iraq Renaissance Socialist Party (Ba'athists) aligned themselves with the notion of ethnicised nationalism that diminished the political space for Kurds (Natali 2005: 34-36). From the 1950s onwards, there existed competing forms of Arab nationalism. The inclusionary discourses of Iraqi identity that were based on the Arab-Kurd relationship provided Kurds with more political space to claim ethnocultural rights. However, in the midst of the Cold War and the fear of communists, Arab nationalists gained more power and began to plan new projects of assimilation and control of Kurdish populations. The Iraqi identity thereby became entirely 'Arabised', as in Syria. In 1963, the Baathists staged a coup and took power. Once firmly in place, 
their policies were directed at Sunni-Arabising, militarising and Bathicising the state of Iraq. In tandem with the petrolisation of Iraq, the state elite began a project to 're-ethnicise' the Kurdish regions through major population relocations of Arabic speakers. The Kurdish areas, which were rich in oil, most notably the city of Kirkuk, became subject to disputes that continue today (Yildiz 2007: 17).

After 1980, Iraqi garrisons were transferred to the Iranian front, which allowed the Kurdish military forces (peshmerga), to gain influence in the region. In 1983, the Kurdish Democratic Party (KDP) - founded in 1946 and led by the Barzani family - allied with Teheran, which angered the then head of the Iraqi state, Saddam Hussein. This was followed by a swift operation by Iraqi troops to abduct between 5,000 and 8,000 men belonging to the Barzani tribe, who were never seen again. The situation of Kurds in the north of the country grew rapidly worse. Between 1987 and 1988, Hassan al-Majid, Saddam Hussein's cousin who later became known as 'Chemical Ali', organised systematic chemical attacks on Kurdish villages located in northern Iraq. These attacks were part of a campaign named the Anfal ${ }^{17}$ and included eight military offensives, physically destroying around 3,000 villages and killing approximately 150,000-180,000 people. More than 180,000 people were left missing (Chaliand 1994; McDowall 1996: 359; Middle East Watch 1993; Yildiz 2007: 25).

As the Middle East Watch report puts it, 'the 1983 Barzani operation foreshadowed the techniques that would be used on a much larger scale during the Anfal campaign' (Middle East Watch 1993: 6-7). For instance, the first campaign, in February 1988, began with attacks on the headquarters of the other Kurdish party, the Patriotic Union of Kurdistan (PUK), and the villages nearby. The massacre of Halabja is often referenced as a reaction of the Hussein's regime to the Kurdish peshmerga's attempt to take control of the city in March 1988 (Middle East Watch 1993: 26-27). Hassan al-Majid organised systematic chemical attacks as well as forced deportations of Kurdish villages located in northern Iraq, acting on the command of his cousin, resulting in some 1.5 million Kurds 
being 'resettled'. The campaigns are said to have destroyed 'the entire social and economic texture of the affected regions' (Mlodoch 2012: 213), with effects of the atrocities still visible today.

The Anfal campaigns took place in three consecutive phases, the last of which included a chemical attack on the city of Halabja in 1988 , where approximately 7,000-8,000 people perished in a single day (Middle East Watch 1993: 102-108). The most horrific event of the Anfal campaigns, Halabja became profoundly emblematic in the collective memory of Kurds and an important memorial site (Khayati 2008: 243). Local policymakers quickly placed Halabja in the centre of the framing of the Anfal campaigns as genocide. Immediately after the Halabja massacre, during a visit to the United States, Jalal Talabani (then the Iraqi Kurdish leader, who later became the president of Iraq), referred to Halabja to ground claims for Kurdish self-rule. ${ }^{18}$

After the Gulf War, in 1991, an autonomous safe haven and a no-fly zone was created in the north of Iraq by the coalition forces to protect the civilian population. A year later, the Kurdish Regional Government (KRG) was founded with the first democratically elected parliament. Under pressure from the United States, the Iraqi government withdrew its political and military presence from the KRI. This allowed the regional government to establish a semi-autonomous Kurdish state in northern Iraq, although the economic and political situation has varied from more or less stable to at times quite volatile. I will further discuss the current situation in the KRI in the next sections.

\subsubsection{Stateless and divided}

As mentioned earlier, the Kurds have never had an officially recognised state. They are not the only ethnonational minority in the world to make claims for one - several others have voiced separatist aspirations including the Tamils, Kashmiris, Sikhs, Tibetans and, more recently, Catalans and Scots, who also organised independence referenda in 2017 and 2014, respectively. The Kurdish case is a bit more complex in the sense that the land area of 
Kurdistan is divided into several nation-states and the claims for Kurdish rights, autonomy or independence differ in terms of the political organisation of Kurds in different countries as well as in their relation to the dominant political power in their respective states. Whereas we can say that the state of statelessness does bear an influence on Kurdish politics in Turkey, Syria and Iraq - as well as in the diaspora - the political claims concerning autonomy and independence are formulated quite differently.

For instance, the KRG in Iraqi Kurdistan clearly has separatist aspirations, as the 2017 independence referendum showed. However, this is not necessarily the case for the political leadership in Syrian Kurdistan, which has rejected a state-centred democracy and nation-state model altogether. Over the last decades, the emphasis in Turkish Kurdistan has also shifted from demanding independence towards an emphasis on cultural and linguistic rights, and a certain level of regional autonomy. This means that it is not only the causes of ethnic separatism and whether it is successful that need to be understood in relation to geopolitical, socio-economic and historical-cultural conditions in specific nation-states but also the lack of such separatism in other parts of Kurdistan.

How this state of statelessness plays out in the case of Kurdish politics - as well as in diaspora politics - is, therefore, more complex than among other stateless ethnonational minorities. Kurdistan is currently divided across four nation-states with historically very different policies and approaches to their Kurdish minorities. Yet, simultaneously, the Kurdish issue, political parties and their historical developments in the region have been transnational and not only confined within the borders of these nation-states. For instance, Syrian Kurds have participated both in the Iraqi Kurdish military troops (peshmerga) in the 1970s and 1980s and in the PKK, operating in Turkey in the 1980s and 1990s (Tejel 2014: 73-76). The influence of the PKK in some Kurdish regions in Syria has been more significant than in others, and some Kurdish political sections in Syria are supported by Iraqi Kurdish parties. 
However, what is common is the fact that, across their respective states, the Kurds have been portrayed and constructed as the national 'others' in the context of nation-state-building processes of the 20th century. Emerging from the ruins of major empires, Turkey, Iraq and Syria adopted political projects of nationhood that shaped notions of citizenship and belonging for decades to come. These nationalist projects created different notions of exclusion and inclusion and consequently on several occasions constructed the Kurds as not only the 'other' but also 'the national other' that needed to be assimilated or even exterminated. As a result, the Kurdish minorities became objects of diverse assimilation policies and even genocidal measures throughout the 20th century.

Naturally, it would be simplistic to reduce the formation and development of Kurdish politics to a reaction towards national policies and minority treatment in these countries. But how Kurdish politics and agendas of different political factions are formulated in today's Kurdistan do stem from the historical treatment of Kurds in each nation-state. The development and emergence of these Kurdish political movements and parties, and their claims-making towards greater self-determination, can - at least in part - be seen as a response to different state policies and emerging in specific political spaces. The Kurdish political divisions and constellations of the 'homeland', including mobilisations, are also reflected in the diaspora. I will next provide a brief overview of the current state of affairs in Kurdistan in the new millennium.

\subsection{Kurdistan in the New Millennium}

The year 2011 was a historical one in the Arab world. It witnessed a series of popular uprisings and protests that started late 2010 and spread from the North African countries to the Middle East. This series of events became known as 'Arab Spring', and it eventually reached Syria in March 2011. In the following years, the instability created by the Syrian civil war spilled over to Iraq and Turkey. It has particularly touched Kurdistan, which lies at the heart of these 
geopolitical powers. The mounting violence in eastern Turkey since summer 2015 followed the collapse of the peace negotiations between the PKK and the Turkish state. The expansion of ISIS to large land areas in Iraq and Syria threatened the Kurdish areas and both the Syrian and Iraqi Kurdish troops engaged in combat with ISIS. More recently, in 2019, Turkey launched a cross-border operation against the Kurdish-led forces in Syria to invade Afrin, before Kurds agreed a deal with the Syrian government. ${ }^{19}$ It is difficult to say what the political configuration and structuration of the region will look like in the next decade, but the first decades of this millennium were quite turbulent for the Kurdish regions in the Middle East and Turkey. Such 'homeland' events have also been reflected in Kurdish diaspora's mobilisation and involvement towards the region.

\subsubsection{The 'forgotten Kurds' of Syria in international spotlight}

The Syrian Kurds have been referred to as the 'forgotten Kurds' as they have received little attention from the media and researchers (Gunter 2014; Tejel 2009), particularly compared to Kurds from Iraq and Turkey. The situation in Syrian Kurdistan drastically changed after the first decade of this millennium, when the Syrian civil war broke out in March 2011. Rapidly escalating after the regime arrested and tortured a group of teenagers in Deraa, protests quickly spread across Syrian cities, with young people calling for democratic reforms and regime change.

In the beginning, the Kurdish political parties remained somewhat divided on whether or not to voice support for anti-government protests. This was also sensed by the regime, who during spring 2011 established citizenship rights for more than 100,000 Kurds, who had lost them as a result of the 1962 decree (Gunther 2014: 2; Schøtt 2017). In October 2011, however, the Kurdish parties established the Kurdish National Council (KNC), sponsored by the KRI's president, Massoud Barzani (Carnegie Middle East Center $2012^{20}$ ). The KNC managed to unite most of the Syrian 
Kurdish parties, but a few left the council, including the Democratic Union Party (PYD).

The PYD had been established in 2003. After the withdrawal of the Syrian government forces in 2012, it quickly filled the power vacuum and declared three Kurdish cantons located in the region of Rojava - Efrin, Ciziri and Kobane - autonomous. The tensions between the KNC and PYD grew rapidly, and in 2012 they formed the Kurdish Supreme Committee, which then became the ruling body in the Kurdish cantons in northern Syria. The following year, the PYD took over control and proclaimed the implementation of the 'Social Contract of Rojava' along the ideas of Abdullah Öcalan (Schøtt 2017). The Rojava model put forth a federal political system with local, self-governed administrative units. Based on the idea of democratic confederalism developed by Öcalan, the model emphasised bottom-up democracy, active citizenship participation, and the equal representation of men and women (Colasanti et al. 2018). This also applied to the military organisation, which became a considerable asset for the PYD in securing control over the Kurdish regions (Knapp, Flach, \& Ayboga 2016).

Kurdish military troops, namely the People's Protections Units (Yekîneyên Parastina Gel, YPG) have operated as the security forces of Rojava since 2012. They have engaged in armed battle against ISIS in the outskirts of the de facto autonomous region of Rojava in northern Syria since 2013 (see Jongerden \& Akkaya 2013). The YPG is affiliated with the Kurdistan Workers' Party (Partiya Karkerên Kurdistan, PKK), although this relationship is often contested since the latter features on the EU's and United States' lists of terrorist organisations. For instance, the YPG received combatants from the ranks of the PKK after attacks on Kobane following the call by the jailed Kurdish leader Abdullah Öcalan, regardless of Turkish border control authorities aiming to block their access to northern Syria.

Currently, the YPG troops include an estimated 30,000-35,000 combatants, of whom approximately $20-40 \%$ belong to the female battalion, Yekîneyên Parastina Jin (YPJ). ${ }^{21}$ The Women's Protection Units have equally taken part in the armed conflict. 
The Syrian civil war has been without doubt the war most widely covered by the international media in this millennium. While the gruesome acts committed by the 'Islamic State' (ISIS) have attracted considerable media coverage, there has simultaneously been a sharp increase in interest towards the Kurdish combatants and their armed battle. The Kurdish Protection Units, particularly the female battalion, have enjoyed quite remarkable media visibility since the siege of Kobane. Numerous international media outlets, including the BBC, $\mathrm{NBC}$ News and $\mathrm{CNN},{ }^{22}$ as well as social media platforms, have provided a close-up perspective of the armed conflict by focusing on female combatants and their military action.

The current situation of Kurds in Syria stands in stark contrast to the situation in earlier decades. From the 1950s onwards, the Kurdish language and cultural rights were harshly repressed, in a similar way as in Turkey, and various bans and restrictions on language, publications, teaching and political participation continued till the first decade of this millennium (Sheyholislami 2015). After 40 years of dictatorship and political marginalisation, the Kurds currently enjoy an unprecedented level of autonomy in northern Syria, although the continuity of their Rojava experiment is far from being secure for years to come, as was shown by the military offensive launched by Turkey in 2019. Furthermore, the Kurds in northern Syria are hardly a united front. One internal division between the Kurds concerns that between the KNC and PYD. As Schøtt (2017: 17) formulates it,

The KNC is accusing the PYD of being lap dogs of the Assad regime, while the PYD is accusing the KNC of being a helpless mouthpiece of the Barzani regime and, subsequently, in the pocket of Turkey.

Two major events have played in favour of the Syrian Kurds, which also made them a more visible actor in the ongoing conflict. The first was the retreat of the Syrian regime from the Kurdish areas, which left the area under the control of the PYD. The second was the emergence of ISIS, which to the Kurds' fortune became the 
common enemy for them and the international coalition (Schøtt 2017). However, Turkey has been dead set against having a PYDled self-government on the other side of the border, as it considers PYD to be the Syrian branch of the PKK, a terrorist organisation that is illegal in the country. This has prompted Turkey to increase its involvement in the Syrian civil war. In 2015, it joined the international coalition in the fight against ISIS, but it seems that this was mostly with the aim of attacking the PKK and PYD in the border region and to stop the latter from acquiring the stretch of land along the Turkish-Syrian border. This was also considered to be the motivation behind the military offence against the Kurdishled troops in 2019, when Turkey and Turkish-backed militias invaded the city of Afrin after American troops withdrew from the region. The animosity towards the Syrian Kurdish political leadership stems from the four-decade-long conflict between the PKK and the Turkish state, and from the idea that the PKK/PYD is possibly threatening the territorial integrity of the Turkish state as guaranteed by the almost-century-old Treaty of Lausanne.

\subsubsection{End of the peace process and amounting state violence in eastern Turkey}

In Turkey, the conflict between the PKK and the Turkish state has lasted for almost four decades. The conflict developed from a lowintensity war to a full-fledged one in the 1990s. According to the Uppsala Conflict Data Program, it has resulted in almost 30,000 deaths and numerous forced disappearances. The 1990s were definitely the bloodiest years of the conflict, until the PKK called a unilateral ceasefire in 1999. The first decade of the millennium witnessed a relatively peaceful period in Kurdish-Turkish relations, especially compared to the previous decade.

After the decades-long conflict between the PKK and the Turkish state, the Turkish-Kurdish reconciliation process started with the 'democratic opening' and secret negotiations in Oslo in 2009. In 2009, then Prime Minister, now President, Erdoğan, launched what was soon named the 'Kurdish opening', in other words 
an approach to end the decades-long conflict. As fragile as the peace process was, the negotiations were effectively pursued till 2013. The Kobane siege also became visible on the Turkish side of the border, as thousands of people took to the streets to protest the siege in an international day of solidarity for Kobane in February 2015. The demonstrations were called by the pro-Kurdish party Peoples' Democratic Party (HDP). ${ }^{23}$ Indeed, Ciordia (2018) suggests that the Kobane siege and the victory by Syrian Kurds over ISIS could be considered a 'transformative moment' in the recent development of the Kurdish-Turkish conflict in Turkey.

The fragile peace negotiations finally collapsed in June 2015. Subsequently, both sides resumed the armed conflict and the escalating violence spread to the country's political sphere. The imposition of curfews on Kurdish cities, state-inflicted violence and the arbitrary arrests of Kurds, and court sentences under the premises of antiterrorism legislation have become frequent from 2015 onwards. Simultaneously, the situation for Kurdish journalists, academics and political activists, but not limited to them, has turned more precarious again in recent years. ${ }^{24}$ In comparison to the 1990s, the methods and dynamics of the conflict differ drastically from those previously between the state and the PKK. The Patriotic Revolutionary Youth Movement (YDG-H), the youth branch of the PKK, declared a 'people's revolutionary war' against the Turkish military forces and took upon itself the role of a paramilitary force in several Kurdish neighbourhoods (Cizre, Şırnak, Sur and so forth) in south-eastern Turkey. This irregularly armed group constructed trenches and barricades in cities, alongside armed checkpoints and patrols, whereas the state imposed a number of curfews on the Kurdish neighbourhoods, thus bringing the conflict to an urban context. The civilian populations were trapped in local neighbourhoods under curfews that become the central scene of this renewed armed dispute (Yanmis 2016).

In March 2017, the UN Human Rights Office published a report depicting how this armed dispute and state violence had led to the destruction of urban infrastructure, sporadic killings and serious human rights violations unforeseen in the post-1990s period in 
Turkey. It concluded that, between July 2015 and December 2016, more than 30 towns had been affected by the curfews and violent clashes, and that between 335,000 and half a million people had been displaced in south-eastern Turkey.

Alongside academics, the crackdown on journalists, public figures, politicians or anyone voicing criticism and dissent towards the government measures has been intensifying (Tekdemir, Toivanen, \& Baser 2018). The putsch in the summer of 2016 provided grounds for widescale purges of military personnel, politicians, journalists, academics and others who were deemed a threat to national security under the declared state of emergency. For instance, a number of Kurdish MPs together with both coleaders of the pro-Kurdish HDP, Selahattin Demirtaş and Figen Yüksekdağ, were arrested in late 2016 and the elected Kurdish municipality leaders belonging to the HDP or pro-Kurdish Democratic Regions Party (DBP) were replaced by decree of the Interior Ministry on the grounds that they allegedly provided support for 'terrorism'.

The current situation stands in stark contrast to the beginning of the decade, when the country experienced a rather open political atmosphere for peace negotiations until the conflict resumed in 2015. For instance, the pro-Kurdish and pro-minority People's Democratic Party (HDP) managed to bypass the $10 \%$ election threshold in the 2015 general elections to have representatives in the National Grand Assembly (Çiçek 2017). Between 2013 and 2015 it took part in peace negotiations with the Turkish government on behalf of the PKK. However, there is now growing evidence of the undemocratic direction the country is steering towards and of the eventuality of the peace process fading further away (Baser \& Özturk 2017).

\subsubsection{The failing Iraqi state leading to Kurdish independence?}

Iraqi Kurdish society looks drastically different from how it did in the 1990s. The Kurds in Iraq have had a semi-autonomous region 
ruled by the Kurdish Regional Government since 1992. The opportunities for Iraqi Kurds further expanded in the aftermath of Saddam Hussein's defeat in 2003 by Anglo-American forces. These developments have encouraged the development of more localised and territorial Kurdish identity, separate from Baghdad (Bengio 2005: 176-179). Since 2003, the region has witnessed unprecedented societal stability and economic wealth, partially in the form of foreign investment. The 2005 constitution paved the way for guaranteed federalism for Iraqi Kurdistan and the following year the two main competing parties, the Patriotic Union of Kurdistan (PUK) and the Kurdish Democratic Party (KDP), signed an accord to reunify the Kurdish provinces under one administration (Mohammed 2016). This was also historical in the sense that the KDP and PUK had not been on good terms and in the 1990s even engaged in a civil war (Yildiz 2007: 28-49).

Overall, compared to the rest of Iraq, the Kurdistan Region of Iraq (KRI) has been politically stable and relatively prosperous. Ever since 1991, the Kurds in Iraq have had administrative control of their area's language education and today the language is used widely across the administration, education and other sectors of society. Prior to that, all education was given in Arabic (SkutnabbKangas \& Fernandes 2008: 50). As Hautaniemi and colleagues (2013: 81) observe, the last decade has seen 'Kurdish society [transform] extremely rapidly from a largely agrarian-based, highly regulated, and state-owned economy to a market economy'. For instance, the burgeoning autonomous region of Iraqi Kurdistan has recently attracted foreign, mainly Turkish, investment and made progress in several sectors of society, although developments in civil society have only occurred slowly (see Gunter 2007). Since 2008, economic and diplomatic relations between the KRG and the Turkish state have become closer, attracting criticism particularly from the Kurds in Syria and Turkey.

Also, the disputes between the parties continue to simmer. The political divisions that cut through the region are quite tangible, and the political landscape was slightly diversified as a result of the Gorran (Movement for Change), which emerged in 2010 and 
challenged the dominant position of the two political parties. The political divisions in Iraqi Kurdistan have long been characterised by divisions between the KDP, headed by Massoud Barzani, the current president of Iraqi Kurdistan, and the PUK, headed by Jalal Talabani, who was the president of Iraq till he passed away in 2017. More recently, however, the neoliberal transformation of the Iraqi Kurdish economy and the related investment boom have been weakened by the endemic corruption and the war against ISIS. Also, relations with the Baghdad government remain fragile, especially after the independence referendum in 2017.

Indeed, in spring 2014, the war being waged in Syria was starting to show spillover effects on Iraq, particularly with the takeover of Iraqi cities by ISIS. Also, in November 2014, some 150 Iraqi Kurdish peshmerga fighters joined the Syrian Kurdish troops to fend off attempts by ISIS to seize Kobane. ${ }^{25}$ The rise of ISIS shook the societal stability of the de facto Kurdish state in northern Iraq, but also provided the KRG with an opportunity to push forward claims for independence. The KRI has clearly been in the process of nation-building after a long period of experiencing contested sovereignty (Mohammed 2016). Not only does it have a national anthem and Kurdish-speaking majority with a common history; it has also managed to gain significant autonomy from the central government. Despite the ongoing crises and the permanent state of emergency in the region, the battle against ISIS and conflicts with the central government of Iraq, the commitment of the KRG to nation-building has not diminished.

The eventuality of an independent Kurdish state since the declaration of the de facto Kurdish state in 1991 seems to never have been as topical as it is now, with the failing state of Iraq (Bengio 2012; Aziz 2011; Leezenberg 2005). The KRG held a referendum for independence in September 2017, evoking reactions from its neighbours Turkey, Iran and Syria, as well as from the central Iraqi government. This will surely affect the KRG's political and economic situation in the long run, as independence claims might destabilise even further the political dynamics 
in the region (Kaya \& Whiting 2017). The current situation of Iraqi Kurdistan still presents challenges, particularly due to the regional pressures and cross-border activities of the PKK, radical Islamic parties, Iranian Kurdistan opposition groups and because Kurdish nationalism in Iraqi Kurdistan seems to be dictated by two identities and parties in power (the KDP and PUK) (Bengio 2012: 179-181).

\subsection{Kurdish Nationalism(s) in the 21st Century}

This chapter has offered a contextualisation with respect to how the Kurdish minorities have been positioned within individual nation-states and how Kurdish identities, nationalism and politics have been shaped differently within the political spaces of Turkey, Iraq and Syria. However, several elements of commonality in understandings of Kurdish identities and nationalism remain. Vali (1998: 82) has convincingly argued that Kurdish nationalism is strongly rooted in the 'dialectic of denial and resistance' in other words, in opposing the denial of Kurdish identities and resisting the dominant national identities in the nation-states in which Kurdish minorities reside. Such national identities have at times been drawn from religious and/or ethnic premises, depending on the political spaces and notions of inclusion and exclusion in the respective states.

On the other hand, Kurdish nationalism in the region has not developed and taken shape in a vacuum, but it has been affected by political developments and significant events concerning the Kurdish populations taking place in neighbouring countries (Barkey \& Fuller 1998: 49-53; White 2000: 129-134). It has been suggested that the Kobane siege and the victory over ISIS that followed represented a 'transformative event' not only in terms of the recent development of the Kurdish-Turkish conflict in Turkey but also 'in the evolution of the Kurdish movement's collective action frames' (Ciordia 2018: 774). Ciordia (2018: 777) speaks of transformative events that can lead to cross-national diffusion, meaning that 'material and organizational tools, demands or episodes 
of collective action' but also 'symbolic elements such as collective identities, solidarity networks, values and ideological or cognitive frames' become diffused across borders (see Della Porta \& Diani 2006: 186-188). This was particularly visible on the side of Turkey, how the Kobane siege triggered mobilisations and affected the dynamics of the Kurdish-Turkish conflict.

We can say that the Kobane siege and the Syrian Kurds' combat against ISIS constituted transformative events that changed the manifestations of Kurdish nationalism in the Kurdish territories. For instance, Gourlay (2018) analyses the surge of pan-Kurdish solidarity in Turkey following the Kurds' combat against ISIS, suggesting that Kurdayetî, pan-Kurdish identity and solidarity, has grown significantly in the Kurdish regions in Turkey, Syria and Iraq via Kurdish communities' cooperation to fight ISIS. Thus, the current manifestations of Kurdish nationalism(s) in the Kurdish territories and in states with significant Kurdish communities reflect the transnational constellations of the Kurdish demographics, identities and politics.

What about the diaspora, then? The political events taking place in Kurdistan and how the local politics in different Kurdish regions look today inform Kurdish diaspora communities' participation and motivations to take part in homeland affairs. This is also the case with Kurdish nationalism(s) and Kurdish identities as they play out in the Kurdish territories, although the development of Kurdish nationalism(s) and identities in the diaspora context are not - and should not be considered - an exact reflection of those in Kurdistan. 'Kurdish national identity' in Kurdistan has been said to be based on living in a common territory - in other words, Kurdish national identity draws from a 'sense of place' and 'homeland' rather than from a 'sense of tribe and blood' (Aziz 2011: 45-46). The state of exile and displacement - whether it is forced or voluntary - is bound to affect the notions of Kurdish identity and 'homeland'. Sometimes, the nationalist feelings can even become more accentuated in diaspora after exile from the 'homeland'. In the case of Kurds, the large-scale displacement of Kurds and the formation of diaspora communities have created conditions 
for the spread of Kurdish nationalism, of whatever sort(s), and shaped the ways in which 'Kurdishness' and Kurdish identities are understood (see Alinia 2004; Eliassi 2010; Khayati 2008). Indeed, van Bruinessen (2000) has examined the relationship between exile and Kurdish nationalism and stated that it was exile that transformed Kurdistan from a vaguely defined geographical entity into a political idea'.

The more recent political dynamics and 'transformative events' are also shaping how Kurdish identities in the diaspora take shape, as later discussed. The argument that I will develop further in the analysis chapters is that the Kobane siege allowed, albeit only momentarily, to overcome the pluralities and divisions that exist within the Kurdish diaspora communities. This included references to common Kurdish identity, Kurdayetî, following similar dynamics to those observed by Gourlay (2018). How this political idea has further developed and how it motivates both the Kurdish diaspora's mobilisation and 'homeland' participation will be the focus in the following chapter. It provides an overview of the Kurdish diaspora formation, particularly focusing on the case of France. It also discusses how, in addition to 'homeland' events, the experiences of displacement and the state of exile, host society experiences, and transnational connections, mobilities, ties and attachments towards 'homeland' all shape what forms diaspora mobilisation and participation towards the ancestral 'homeland' take. The analysis chapters that follow thereafter will then discuss how Kurdish nationalism(s) and identities are changing in the 2010s as a result of 'transformative events', including the siege of Kobane. 
CHAPTER 4

\section{How the Kurdish Diaspora(s) Came to Be}

\subsection{Introduction}

Migration from countries in the Middle East to Europe is neither a new nor an isolated phenomenon but closely linked to economic, political and social transformations that took place across the world in the 20th century and hence to processes of global integration. Whereas 19th-century international migration was fairly uncontrolled and unregulated by any legislation, and characterised by mass migrations from Europe to North and South America, the beginning of the 20th century witnessed the introduction of legislative measures curtailing migrants' free movement. In the early post-Second World War period, offering asylum became a way to address labour shortages and to help recovering economies in Western Europe, and this practice gradually evolved into migration policies that aimed to actively recruit migrants from developing countries. Therefore, international migration to Western Europe took place within the framework of labour migration till the 1970s, when in response to the worsening economic situation, particularly after the oil crisis in 1973, immigration became more restricted. Also, as a consequence of political turmoil, the number of political asylum-seekers and refugees globally increased more than tenfold towards the end of the century: in the period between 1975 and 1995, the number of refugees rose from 2.4 million to 27 million (Castles, de Haas, \& Miller 2014; Schindlmayr 2003: 116). 
The scope and the intensity of migration from Turkey, Lebanon, Iraq, Iran and Palestine and more recently from Syria towards Europe have also been tightly linked with the societal, economic and political developments taking place within these countries. Therefore, the formation of Middle Eastern diasporas in Europe have come together as something of an amalgam of more voluntary, labour-induced migration and of involuntary conflictgenerated, forced migration, depending also on the receiving countries' migration regimes. The formation of Middle Eastern diaspora communities has been shaped not only by the political and societal changes in the ancestral homeland but also by the conditions in the societies of settlement, including the humanitarian and labour policies installed at the time of migration. Furthermore, the formation of diaspora communities has also been shaped by different integration regimes, institutional structures and discursive practices in the receiving society. In other words, how the newcomers have been received, how they have been able to establish associations and to maintain contacts and ties to their closest circles back home, and what institutional measures concerning education, work, accommodation and so forth have been in place upon arrival have all affected the formation of Middle Eastern diaspora communities in Europe (Baser \& Halperin 2019; Baser \& Toivanen 2018a).

The formation of Kurdish diaspora communities across Europe (and beyond), and more specifically in France, is no exception to this. In this chapter, I wish to examine, however briefly, the characteristics of the formation of the Kurdish diaspora communities in Europe, before moving to discuss it in more detail in France. The formation of Kurdish diaspora communities in France does have several specificities that are due not only to differing institutional or political contexts but also to different constellations of Kurdish migration. However, at the same time the formation of Kurdish diaspora communities in the latter part of the 20th century is inscribed into larger economic migrations from the region, but also into experiences of forced migration, dispersal, exile and, 
specifically in the Kurdish case, statelessness. It is imperative to discuss these dimensions if we are to understand the life trajectories and experiences of Kurdish diaspora members. For this reason, I have employed narrative accounts of Kurdish migrants and their descendants to show how individual life stories intersect with major historical events.

\subsection{The Dispersal and Exile}

Interviewee: So I was born in 1977 in Kurdistan and completed my studies in journalism there. I worked for a TV channel, but then I was discussing Kurdish history in a live show and I was put aside and forced to quit the job before the channel had any troubles. So, I arrived in France in 2002 and started studying French.

MT: Is that the reason you came to France?

Interviewee: In part, yes. When you talk about France, you talk about democracy. There are many things to criticize about France, but it's not comparable to Turkey. So in the beginning I was a political refugee.

Azad

So, my father was born in Erzerum, a Kurd from Turkey. He went to high school, then to university, and had to complete the mandatory military service. After three years of university studies, he was forced to leave the country following the oppression of the 80s. So he arrived in Europe, through Greece, then via southern France to Germany, before landing in Brittany and later in Paris with fellow comrades. He barely had anything, and he had to work hard and learn French. He is resourceful, so it was fine. He opened his business at the age of 30 , so when he arrived he was about my age, a bit over 20 years old ... He adopted well to the French way of life, and he met my mother here.

Berivan 
Azad belongs to the first generation, as he arrived in France at an adult age. He tells of the difficulties he experienced in his profession in Turkey, due to the sensitivity of the Kurdish issue, and of the reasons for migrating to France. At the time of the interview, he was working in the construction business, contrary to his education in journalism. Berivan, on the other hand, belongs to the so-called second generation. She recounts her father's motivations to leave Turkey in the 1980s and how he ended up leaving the country and moving to France. Both accounts offer an example of the challenges of sorting individual life stories into neat categories, classifications or types of migration. For instance, whereas on the basis of Berivan's account her father's migration would more traditionally be considered and interpreted as an example of labour migration from Turkey to France (regardless of the underlying political reasons), Azad's migration story would fall into the frame of politically motivated migration from Turkey to France.

However, what was common to both of the stories was the very human desire of Azad and Berivan's father to find both financial and societal security, and eventually the possibility to provide for a better life for themselves and their offspring. This, one might argue, is a commonality shared by a large majority of people on the move, and for people permanently settled in one place, for that matter. But what also makes both stories similar was how these two individuals recounted the feelings of injustice towards what was considered historical wrongdoing by the Turkish state against the Kurds, which then led to an exile from Kurdistan. For both, this was counted as part of their life story, a reason why they lived at that particular moment in France. One could also notice some resemblance in how Azad and Berivan described their experiences and daily lives in the Kurdish diaspora community. To put this in theoretical jargon, their lived experiences could be characterised as transnational and inscribed in the Kurdish diaspora space, where references to understandings of 'Kurdishness' and to Kurdistan as the 'homeland' were frequent. In that way, the historical dispersal and migration of Kurds, and even exile, constituted integral parts of their life stories and how they made sense of 
their current lives. However, Azad had directly experienced displacement himself, unlike Berivan, for whom it was a 'transmitted experience' in the sense that it had become part of how she narrated on her life and on the reasons she was born in France and not in Kurdistan. I will discuss such generational differences in more detail later.

So, let us now move to the historical events that shaped the formation of Kurdish diaspora communities in Europe in the latter part of the 20th century. ${ }^{26}$ The literature teaches us that two major developments led to the resettlement of Kurds in diaspora communities around the globe in the 20th century (Hassanpour \& Mojab 2005: 218). The first has been traced back to the economic boom witnessed by Western Europe since the 1960s. For instance, the guest worker programmes initiated between Germany and Turkey attracted a great number of Kurdish migrants from Turkey, who settled mainly in Germany but also on a smaller scale in Belgium, the Netherlands, Denmark, France and Sweden. This meant that, by the 1990s, the largest Kurdish population in Europe lived in Germany, accounting for roughly half a million Kurds, most of whom had migrated from Turkey (ibid.). This pattern of labour migration started to shift towards the end of the century, as migration policies focalising on bringing in foreign labour became more restricted and complemented to some extent by policies opening venues for migration on the basis of humanitarian reasons. In other words, the general patterns of Kurdish migration to Europe follow those in international migration to the continent.

Secondly, the unstable political situation in the Kurdistan region was a major factor that led to the formation of Kurdish diaspora communities across Europe, including also in the northern parts of Europe. Various state policies, including assimilation measures constituting part of the nation-state-building strategies as described in Chapter 3, led to increased tensions between the Kurdish populations and the state in Iraq, Iran, Turkey and Syria. Armed conflicts between the Kurdish factions and the state that occasionally involved international forces were a frequent 
characteristic of the interethnic relations in Iraq (1961-2003), Iran (1967-1968 and 1979 to today), and Turkey (1984 to the present) (Hassanpour \& Mojab 2005: 218). Although there had been a few Kurdish scholars, journalists and nobility living in Europe in the early 20th century (some in exilic conditions too), the new Kurdish diasporas in the latter part of the century emerged in the context of armed conflict, state oppression and coercive assimilation measures (ibid.).

To make matters a bit more complex, there were not only regional differences as to the dispersal of Kurds from the Kurdish heartlands but also variations in migration waves, particularly in the case of forced migration, traceable to different political disturbances. For instance, in the case of Iraq, the forced displacement since the 1970s has taken place in several stages. One of the major waves occurred in the aftermath of the Gulf War (1990-1991) and after the Kurdish uprising in 1991. Although it was encouraged by the United States and its allies, the Kurdish uprising was not militarily backed by the international forces and it was quickly crushed by Saddam Hussein's forces. The end result was 20,000 being killed and a vast mass migration towards Turkey and Iran taking place, with a total of a million people on the move (McDowall 1996: 372; Yildiz 2007: 36). Also, many people fled to the mountains, in a sad echo of the well-known Kurdish saying 'Kurds have no friends but the mountains'. The United Nations High Commissioner for Refugees (UNHCR) has described this as the 'highest rate of influx' in the 40-year history of that office (Yildiz 2007: 36-37).

This was followed by further forced displacement of Kurds in the course of the 1990s due to political instabilities in the region (Hassanpour \& Mojab 2005: 217-219; Human Rights Watch 2004). For instance, the 1994-1997 civil war between the Kurdish parties in Iraq created instability, and by the late 1990s thousands of refugees from Iraqi Kurdistan had migrated to the neighbouring countries and Europe (McDowall 1996: 372-373, 387-388). Furthermore, when looking at particular political events, one can see that the Kurdish migration towards Europe was fuelled by the Iraqi state's deliberate destruction of thousands of Kurdish villages 
between 1975 and 1991. As discussed in the previous chapter, these included the notorious Anfal campaigns, with gas bombings specifically targeting Kurdish villages.

In those years, numerous families left Iraqi Kurdistan for Turkey and later, after having lived there for some years, received asylum in European countries. The internal displacement of Kurds in Iraq but also in Iran led to migration trajectories of Kurdish refugees passing through Turkey, Jordan and other countries before some of the families ended up migrating, most often via Turkey, to Europe. Migration trajectories often passed through several countries, even across Kurdish regions situated in different nationstates. For instance, after 1979 the armed conflict between the Kurds and the Iranian state sent flows of migrants from Iranian Kurdistan to Iraq: between 1979 and the 1990s, several thousand Iranian Kurds and members of Iranian Kurdish political groups were fleeing the Iranian government and heading for Iraq, including to Iraqi Kurdistan. Some also settled in the Al-Tash refugee camp, in Al-Rumadi, a town next to the Iraqi-Jordanian border. After spending several years in the camp, some families were relocated to northern European countries by means of the UNHCR settlement measures (see Khayati 2008: 215).

Turkey played a role as both a transition country and a country of departure in Kurdish migration. Besides Iraqi and Iranian Kurds who passed through Turkey to Europe in the late 1980s, there was an increase in the number of Kurds migrating from Turkey to Europe. This was partially due to the violent conflict between the PKK and the Turkish state, as set out in the previous chapter. Furthermore, the state's so-called 'forced urbanisation' programmes implemented in eastern Turkey destroyed thousands of Kurdish villages and consequently led to forced displacement. Estimates of the internally displaced populations vary, depending on the source. The number of internal displacements of individuals resulting from 'terrorism' and from conflict-induced displacement alongside forced urbanisation amounts to between 353,000 (by government authorities' estimates) and 2.5 to 3 million (according to various NGOs). ${ }^{27}$ It has been said that eastern Turkey, 
which is inhabited mainly by Kurdish populations, became a sort of concentration camp by the late 1980s, 'where every citizen [was] treated as a suspect and where oppression, torture and insult by the military [were] the rule rather than the exception' (van Bruinessen $1988^{28}$ ). In practice, for the local populations this meant living at a pressure point between the PKK and the state in their ongoing fights and also in fear of arbitrary abduction, imprisonment, killing or other violent methods to settle the so-called 'eastern issue' (Zeydanlığlu 2009).

Indeed, thousands of people went missing in the 1990s and 2000 s in police custody in eastern Turkey, with some still remaining unfound. Between 1994 and 2003, there were 800-900 cases reported of enforced disappearances in Turkey (Human Rights Watch 2012). ${ }^{29}$ Since 2009, excavation of mass graves has been under way in eastern Turkey, with the purpose of locating some of the individuals who went missing in the 1980s and 1990s. ${ }^{30}$ Since 1995, some family members of the missing persons have gathered in Istanbul for a silent protest of the fate of their relatives. This protest movement, called Saturday Mothers (Cumartesi anneleri in Turkish), displays mostly female family members holding pictures of their missing relatives (Ayyildiz 2007: 333334). I witnessed and attended one such event, organised in Paris in $2016 .^{31}$

Not only have such political developments and upheavals profoundly transformed the Kurdish societies and led to mass migration of Kurds within the Middle East and beyond. They also resonate in the diaspora and in its members' understandings of Kurdistan and 'Kurdishness'. And not surprisingly so since the formation of the Kurdish diaspora across the world can be traceable, at least to some extent, back to nationalist policies and majorityminority relations discussed in the previous chapter. There, I raised two dimensions in particular, the 'state of statelessness' and the division of Kurdish lands dating back to the early 20th century as things that even today continue to shape the Kurdish politics, as well as the meaning-making processes regarding Kurdish identities and understandings of home(land). 
These dimensions are also relevant in understanding the formation of the Kurdish diaspora communities outside Kurdistan. Firstly, Kurdish migration from the region needs to be understood not only as the coming together of a different set of economic, social and political circumstances in the sending region at the time of migration but also against the historical context of the divided and stateless Kurdistan, which events have led to it and how that has led to the formation of Kurdish diaspora communities around the globe. In other words, the 'fifth part' of Kurdistan, referring to the Kurdish diaspora, could look quite different today if the other 'four parts', in Iraq, Iran, Turkey and Syria, did not exist.

Secondly, the state of statelessness, division of Kurdish lands, and, relatedly, the dispersal and exile have all informed the formation of transnational Kurdish diaspora communities and, with it, also the formation of the Kurdish diaspora space, in the sense of transnational social space as discussed in Chapter 2. How Kurdistan is being referenced, what understandings Kurdish identities entail, and how this 'transnation' maintains and fosters cross-border networks, affiliations and ties relates closely to how diaspora members make sense of their personal stories and experiences. As relevant as it is to understand the current state ramifications of this division and statelessness from a historical perspective, it is equally important to see how individual stories are situated within and draw from collective memories, histories, narratives and experiences of exile and statelessness. Indeed, the transnational space of Kurdish diaspora communities shows particular dynamics in terms of exile and the sense of 'otherness' that continue to be informed by the ongoing situation of Kurdish minorities in the Kurdistan region as well as ingrained into the collective memory of the past.

\subsubsection{The Kurdish diaspora(s) in numbers}

What is the size of the Kurdish diaspora outside the region of Kurdistan? The question is as difficult to answer in detail as it was to estimate the total number of Kurds living in the Kurdistan 
region in Chapter 3. There are several reasons for this, some more generally applicable to diaspora groups dispersed in several nation-states, and others more specifically touching upon the Kurdish communities.

Collecting information from several different sources that have aimed to pinpoint the number of Kurds living in Europe, the estimates move around 1.7 million and 1.943 million individuals (Kurdish Institute ${ }^{32}$ ). It is considered that the great majority of this number is Kurds from Turkey who are residing in Germany some estimates going up to 85\% (European Commission 2006; Institut kurde de Paris; ${ }^{33}$ Wahlbeck 2019). Furthermore, there are sizeable Kurdish populations in France, the United Kingdom, Sweden, the Netherlands and Belgium, ranging from some 100,000 Kurds in Sweden to over 200,000 Kurds in France. The formation of the Kurdish diaspora community in France is discussed in more detailed in the following section.

Firstly, it is difficult to cite accurate figures with respect to the numbers of Kurds living in Europe, because data-collection procedures differ between national censuses. The number of Kurds cannot be listed solely based on the country of origin or by citizenship statistics, as the first-generation Kurds in the diaspora can be citizens of Iraq, Iran, Syria and Turkey, or even non-citizens in some cases. This is less true for other diaspora groups, although the issue is not that clear cut for all. For instance, in Germany, the statistics are collected on the basis of citizenship or the country of birth, for which reason Kurdish-speaking migrants with Turkish citizenship tend to be invisible in the official figures and registered as Turkish, Iraqi, Iranian or Syrian citizens. This also seems to be the case in several other countries that collect population data related to such variables as citizenship and country of birth instead of ethnicity or language. There, too, individuals with a Kurdish background are invisible in the statistics. Furthermore, it is likely that thousands of undocumented Kurdish migrants not visible in national statistics reside in Europe (Baser 2011: 8). On the other hand, language-based statistics would be one way to collect data on different ethnic groups, but this is not done in most 
European countries, with a few exceptions. Then again, this would not necessarily allow factoring in the second-generation members or their offspring, who are not Kurdish speakers but might still identify themselves as 'Kurdish', at least to some extent.

This moves us to the second issue. Even if we were able to provide accurate estimates of the Kurdish populations outside the Kurdish regions, how would we draw the criteria for a diaspora and who is considered to belong to it? For instance, the city that hosts the largest Kurdish population outside the realms of Kurdistan is Istanbul in Turkey. Owing to internal migration of Kurds from the eastern parts of the country starting from the late 1980s till the 1990s, it has been estimated that the city hosts approximately three million Kurds, ${ }^{34}$ depending on the definitions used (Houston 2005). This comes back to the question raised in Chapter 3 as to who the Kurds are and how to provide accurate figures of Kurdish populations scattered across four nation-states. It also touches upon the theoretical question raised in the previous chapter, as to what actually constitutes a diaspora: which different communities or individuals belong to it and which do not. It is a valid question as it allows us to ponder to what extent we can consider Kurdish communities that are exiled from the region of Kurdistan, yet not necessarily internationally displaced, a diaspora. And do the internally displaced communities constitute diaspora communities that are radically different from internationally displaced communities? Both questions - the one concerning the accurate number of Kurds in Kurdistan and the other on internally displaced diasporas - however relevant to reflect upon, remain nevertheless outside the focus of this particular study.

Regardless, I reference them briefly here to discuss the need to be wary of how information is gathered and used on different 'ethnic' and language groups. Producing research knowledge, for instance in the form of gathering statistics, not only continues to be shaped and structured according to a nation-state-centred logic (Wimmer \& Glick Schiller 2002) but it can also reflect the historically uneven power relations. In other words, knowledge can be selectively employed by those in power to justify governance and 
maintenance of power hierarchies. In this sense, knowledge production is in many ways linked to power, control and recognition, concerning Kurdish populations not only in the Kurdish regions (see Toivanen \& Baser 2018) but also in the receiving societies (Pratsinakis 2017). Therefore, when discussing numbers concerning Kurdish populations, they should be taken with a pinch of salt.

\subsection{Organised and Active: Kurdish Diaspora Online and Offline}

In addition to more familial ties and networks, Kurdish diaspora communities have over time created non-territory-based networks and contacts, and established political, cultural, social and educational organisations and institutions. Kurdish associations in Europe today are numerous and characterised by a great diversity in terms of ideological and political orientations, even though a great number of associations that were created in the 1970s and 1980s did not last more than five years.

For instance, the Kurdish Institute in Paris was created in 1983 by Kurdish intellectuals living in different European countries. Founded with the support of Mitterrand's government, it defines itself as 'an independent, non-political, secular organisation, embracing Kurdish intellectuals and artists from different horizons as well as Western specialists on Kurdish Studies. ${ }^{35}$ On the other hand, the Kurdish Parliament in Exile and the Kurdistan National Congress (KNK) were exemplary cases of multinational and non-territory-based platforms (van Bruinessen 2000). The KNK was established in 1999 in order to create an organisation that would be more representative of Kurds than had been the Kurdish Parliament in Exile, which later became part of the KNK. The KNK groups several Kurdish groups and parties, and calls for the self-determination for Kurds. However, it has struggled to attract wider participation among Kurds, as it has been considered to be too close to the PKK (Gunter 2011: 180-181).

The best-known Kurdish organisation is the PKK, originating from the left in Turkey and founded in 1978 (Jongerden \& Akkaya 
2011). It was known for the strategic use of violence, although it has been suggested that this use of violence was instrumental and rational, owing to the narrow political space in Turkey and lack of alternative platform for political expression (Bozarslan 2004: 23). However, the organisation has gone through a significant change in the new millennium (Akkaya \& Jongerden 2012; Casier \& Jongerden 2012; Grojean 2008). Indeed, Akkaya and Jongerden (2011) suggest that the PKK has reinvented itself in the 2000s, from a 'national liberation struggle' to a project of radical democracy, based on the rejection of the state. Gradually, the organisation has become a political and social movement with extensive transnational networks and connections (Akkaya \& Jongerden 2012; Jongerden \& Akkaya 2016). One first-generation interviewee active in a pro-PKK organisation reported how the movement had changed over the years:

Before, it was the operation of Kurdish cultural centres, before 2007 , and now, today, there has been gradually put in place a system that we call a democratic centre that are popular assemblies uniting the diaspora and that creates different commissions to serve the needs of the diaspora.

The interviewee made reference to the 'cultural centres', which are basically pro-PKK diaspora organisations. Indeed, the PKK founded several transnational associations in Europe in the 1980s, many focusing on women and youth. ${ }^{36}$ In the 1980s and 1990s, it worked particularly towards the institutionalisation of ties and activities in the diaspora, with the 'Europe Bureau' recruiting highly skilled second-generation members and young labourers (Argun 2003: 123; Mügge 2010: 181-192). Adamson (2019: 223) notes how Kurdish political exiles from Turkey set out a 'diaspora engagement policy', managed largely via the PKK and linked to the ongoing conflict in south-eastern Turkey, in order to politicise segments of migrants who had arrived from Turkey.

In fact, it was not until the arrival of more politicised Kurds from Turkey that the previously arrived economic migrants started to identify themselves as 'Kurdish'. The violent conflict between the 
Turkish state and the Kurdish movement in the 1980s was one of the main migration motivations of Kurds to Europe (Hassanpour \& Mojab 2005) and has been considered one of the reasons for the high level of politicisation of the Kurdish community in France (Khayati 2008). Also, studies conducted in Germany show that the identification as Kurdish became more pronounced in the 1980s and 1990s, partially due to the arrival of political refugees (Østergaard-Nielsen 2003; van Bruinessen 1998) but also due to the experienced discrimination and exclusion in the host society. Wahlbeck (2019) also notes that, although labour migration from Turkey has been the single most significant factor to account for the size of the Kurdish communities in Europe, the more recently arrived Kurdish refugees have had a great social, cultural and political impact on the existing Kurdish communities in Europe.

Today, the largest organisation of diaspora Kurds is the KCD-E (European Kurdish Democratic-Societies Congress, before 2013 known as KON-Kurd). It groups 12 federations and 165 associations in the Western world (Dryaz 2015: 452-453) and is considered to have close ties to the PKK. One such federation is the CDK-F (Conseil démocratique kurde en France, formerly FEYKA), consisting mainly of Kurds from Turkey and grouping 24 associations across France. ${ }^{37}$ The pro-PKK associations continue to have a strong standing in France, although there is evidence of the emergence of second-generation associations that are less political in nature (Karagöz 2017), following a similar trend witnessed elsewhere (Schøtt 2021 forthcoming).

There is long history of Kurdish political activism in France, going back to the 1970s and 1980s (Bonzon 2015;38 Werdî 2006 ${ }^{39}$ ). The Kurdish actors have quite successfully established connections with the French Socialist Party and the local representatives in Brittany region, which have then been highly instrumental in raising awareness and lobbying policymakers, for instance during the plight of Kurds in Iraq in the early $1990 s .{ }^{40}$ For instance, Danielle Mitterrand, the wife of François Mitterrand (president 1981-1995), was named the 'Mother of Kurds' for her active role in support of the Kurdish cause. Also, President Hollande knew 
one of the killed activists (Marchand 2017: 30). More specifically, in Paris, Rémi Féraud, the mayor of the 10th arrondissement in Paris, which hosts the Kurdish Institute, the Ahmet Kaya Center and many Kurdish (and Turkish) businesses (Petek \& Poinsot 2015), has been very vocal about the situation of Kurds in the Middle East and Turkey in the Senate. Another pro-Kurdish politician who needs to be mentioned is the mayor of Paris, Anne Hidalgo. For instance, in 2014 during her visit to the Kurdish Institute in Paris, she announced humanitarian aid worth $€ 160,000$ granted by the city hall of Paris to three NGOs and directed to Kurdish civilians who were victims of war. ${ }^{41}$ Overall, Kurdish diaspora associations have played a key role in the social and political organisation of the Kurdish communities in France.

Grojean (2015: 53) observes that the majority of Kurdish diaspora mobilisations taking place in Europe are originally by diaspora Kurds from Turkey. One major example of that is the political demonstrations organised simultaneously by Kurdish organisations in Europe, including the one that followed the arrest of the Kurdish leader Abdullah Öcalan in 1999. Since then, thousands of Kurds gather every year, notably from France and Germany, in Strasbourg, where the European Parliament is located, to protest for his release. In 2017, between 12,000 and 15,000 protesters attended the Strasbourg demonstration, including diaspora Kurds from France. Some of them walked to Strasbourg from their cities of residence. ${ }^{42}$ Till today, the pro-PKK organisations in Europe hold a significant power of mobilisation in the aftermath of events taking place in Kurdistan. ${ }^{43}$

Overall, the Kurdish diaspora associations continue to play an important role concerning the mobilising power of Kurds in the transnational space. Besides political activities, associations are also centred on cultural and social events. The main event of the year is the Newroz party, the traditional new year celebration, organised in late March. It has been suggested, in fact, that the celebration of Newroz is a political manifestation to show support for the Kurdish cause and to celebrate Kurdish identity (Wahlbeck 1999: 170-171). In earlier years, the emergence of a number of 
Kurdish newspapers, magazines, publishing houses and television channels informed the diaspora Kurds of the events taking place in Kurdistan. They have led to the creation of a Kurdish-speaking space. One of the clearest examples of this is the role Kurds in Sweden have played in the creation of standardised, written Kurmanji. Also, the international journal Kurdish Studies and the academic network Kurdish Studies Network were founded by a Sweden-based Kurdish scholar, Welat Zeydanlioğlu, some years ago. ${ }^{44}$ The last decades have also witnessed the emergence of the Kurdish cinema, literature and arts that have found means to flourish in the diaspora via Kurdish film festivals, art exhibitions and published work by Kurdish authors (Galip 2015; Koçer 2014; Smets \& Sengul 2016).

The online space and the role of ICT tools has been particularly significant in forging the transnational space of Kurdish diasporas (Hassanpour 1998; Sheyholislami 2010, 2011; Smets 2016). One particularly noteworthy example of this is the large number of Kurdish-language periodicals published in the diaspora, relative to the number of such publications in Turkey. There is also a large number of broadcasting channels in the diaspora: for instance, in 2010 there were around 15 channels broadcasting in Kurdish (Sheyholislami 2010). Indeed, the continuous political developments in the Middle East are lived among the diaspora Kurds, who stay connected to Kurdistan through satellite channels, ICT tools, social networking sites and long-distance telephone calls (ibid.). This is visible in the immediate reactions to significant political events in Turkey, Iraq and Iran, which prompt demonstrations, lobbying, distribution of petitions and other political activities in the diaspora.

The 'Kurdish issue' has received particular international attention in the aftermath of events such as the atrocities committed by Saddam Hussein against Iraq's Kurdish populations, the 1999 arrest of the leading figure of the PKK, Abdullah Öcalan, and more recently during the Syrian Kurds' combat against ISIS. The role of Kurdish diaspora organisations and their efforts in lobbying and awareness-raising initiatives have been important in this regard. 
Thus, in conjunction with the virtualisation of the 'Kurdish issue, another remarkable development has been its internationalisation and deterritorialisation (Hassanpour 1998; van Bruinessen 1999b), thanks to increased media coverage of Kurdish-related news and the emergence of cross-border Kurdish institutions. Van Bruinessen (2000) suggests that Kurdish nationalism has greatly benefited from the Kurdish diaspora and the emergence of Kurdish institutions, associations, lobbying groups, media and networks in the said diaspora. Such diversity of political, social and cultural activities within the Kurdish diaspora space has given a new dimension to Kurdish nationalism, including in the 2010s. However, these activities have not always been without contestation.

\subsubsection{Contestations and struggles for recognition}

The PKK is considered a terrorist organisation in Turkey, and has been strongly criminalised for several decades. In fact, the threat posed by the PKK in Turkey has been recognised as the most serious one faced by the country since its foundation in 1923 (Özdag 2003: preface). Turkey has also pressured other countries to criminalise pro-PKK activities outside Turkish territory, namely in the diaspora. Since the 1990s, the Kurdish-Turkish conflict has to some extent extended to the European space and the impact of the Turkish state's pressure have been visible in a number of arrests orchestrated by Turkey (Rigoni 1998, 2000), targeted at certain Kurdish associations and their members. One result of such pressure has been the addition of the PKK to the list of terrorist organisations by the United States in 1997 and by the Council of the European Union in 2002 (Boon-Kuo et al. 2015).

The criminalisation of some pro-PKK activities and associations also needs to be understood in the context of intensifying securitisation in Europe, particularly after 9/11. The European Commission declared in 2001 that its main objective was the 'war on terror'. This consequently modified its approach vis-à-vis the Kurdish question, with the addition of the PKK to the list of terrorist organisations (Kurban 2014). The aim of this listing was 
to prevent and freeze funding of the organisation, which has since resulted in the prosecutions of several Kurds for financing and supporting the PKK in Germany, France, Belgium, Denmark and Italy (Boon-Kuo et al. 2015: 119-120).

Different EU states have put in place and reinforced the existing security measures in the context of the 'war on terror'. The EU has adopted a particularly active role in reinforcing pre-emptive security measures instead of relying on the rule of law (De Goede 2008). Different EU countries charged politically active diaspora members for pro-PKK activities in the 2010s, although there exist significant differences between EU countries in this. For instance, Sentas (2015) notes that the criminalisation of Kurdish organisations in the United Kingdom has intensified since 2009. The Kurdish communities have drawn attention to the harassment, intimidation and detention orders by the British authorities towards politically active diaspora members. Numerous examples show how Kurds have been the object of control and stop-and-search under the auspices of antiterrorist legislation (Sentas 2015).

Also, in 2008 a case was opened in Belgium charging 36 persons for their alleged participation in the activities of a 'terrorist organisation' Finally, in 2020, the Judge's Council Chamber decided not to charge the accused, ruling that the national law on terrorism was not applicable considering the nature of the TurkishKurdish conflict. This decision was met with fierce reaction in Turkey. ${ }^{45}$ In Germany, the organisation was criminalised as early as the late 1980s and forbidden immediately afterwards. In 2008, Germany took the decision to forbid the Kurdish channel Roj-TV, considered to be the mouthpiece of the PKK. Germany also intensified their surveillance of the PKK's activities in the country in 2008, after the organisation abducted three German hikers in Turkey, demanding that 'Berlin stop its hostile politics towards the Kurds and the PKK in Germany'. The hikers were released 12 days later (Eccarius-Kelly 2008: 10). Today the protest activities and events organised by Kurdish communities in Germany aim at the removal of the PKK from the list of terrorist organisations (Baser 2015a). 
This took another turn with the Kurdish combat against ISIS that attracted fighters from abroad joining both sides. For instance, in March 2015, a young British woman of Kurdish background was charged in court for having joined the Kurdish military brigade in northern Syria. This brought about a lot of media attention, especially since the YPJ (and its masculine counterpart, YPG) were not listed as terrorist organisations in Britain. ${ }^{46}$ Also, Schøtt (2021 forthcoming: 150-153) discusses at length in her upcoming book courtroom activism by Kurdish diaspora members in Denmark. She opens in detail the cases of Joanna Palani and Martin from Esbjerg, both of whom faced the confiscation of their passports and a travel ban due to their military engagement in Kurdish forces. Both actually argued that they had not been part of the Syrian Kurdish YPG/YPJ troops but instead the Iraqi Kurdish peshmerga troops. The court case against Martin was found in his favour, as 'he only fought for the Peshermerga, a Western and thus Danish allied in the battle against Islamic State' (Schøtt 2021 forthcoming: 162). In the case of Palani, the court confirmed the charges for breach of the travel ban and sentenced her to nine months in prison (ibid.: 162-163). I will discuss the situation of the PKK and court cases that have been opened in France in more detail in later chapters.

Whereas the Kurdish associations and their members have been the object of judicial processes in France, Germany, Belgium and Great Britain, the Nordic countries have been less inclined to pursue them in court. Pro-PKK diaspora activities have been more tolerated, although to a lesser degree in Denmark. One notable case is that of Roj-TV, where the channel was charged in 2010 for its alleged support of terrorism. The channel appealed to the European Court of Human Rights, which backed the domestic courts in Denmark and rejected the case in $2018^{47}$ (see Schøtt 2021 forthcoming). Since 2004, the Turkish state has sent more than 20 appeals concerning the channel to Danish authorities, accusing it of being connected to the PKK and calling for its closure (Ayata 2011). In Sweden, some activists suspected of belonging to the PKK have even been deported after two assassinations committed by members of the organisation in the 1980s. Regardless 
of this case, the Swedish state's attitude has remained quite tolerant towards the Kurdish organisations and their members (Baser, Ahmedi, \& Toivanen 2017). In a similar way, Kurdish associations have not faced judicial processes in Finland or in Norway.

Securitisation, as understood in the research literature (Buzan, Wæver \& de Wilde 1998), applies not only to security measures and policies but also to how potential security threats are constructed via political discourses. In Turkey, the construction of the Kurdish movement as an imminent threat to national unity has enabled a strong criminalisation of activities by individuals suspected of belonging to Kurdish organisations. The political discourses concerning the Kurdish question in Turkey, including the vocabulary used to refer to the PKK, have contributed to a strong association of the Kurdish question as a security concern and a problem of 'terrorism' (Martin 2018). Such securitising discourses also have a transnational dimension. For instance, Baser (2015a) has noted how the political discourses in Germany concerning the PKK have been greatly influenced by the discourses designating the organisation as 'terrorist' in Turkey. However, in 2016 the EU demanded that Turkey check the legal definition of 'terrorism' in its antiterrorist legislation, which the EU considered not to conform to democratic principles and which is currently being used to charge political actors (including Kurds) in Turkey. ${ }^{48}$

Such discourses on 'terrorism' should be understood in the context of larger discursive frames and politics of governmentality, particularly in relation to discourses on the securitisation of borders and the 'war against terrorism' (Squire 2009). For instance, the documentary filmmaker Kevin McKiernan ${ }^{49}$ has argued that the US State Department draws a distinction between 'good Kurds' and 'bad Kurds'. The 'good Kurds' are the Kurds of Iraq, who suffered under the regime of Saddam Hussein and have fought for themselves in the years since for an autonomous region in northern Iraq, while the 'bad Kurds' are Kurds in Turkey, who seek cultural and linguistic rights and even autonomy within the Turkish state, thereby possibly threatening its territorial integrity. Also, the international media refer to the PKK/Turkey conflict 
varyingly as a fight between terrorists/guerrillas/freedomfighters/insurgents and the Turkish state. The media plays a significant role in the reproduction of this discursive frame. ${ }^{50}$

The exceptional measures concerning the 'war on terror' were normalised in the political declarations that appeared in the French, Italian and British press after 9/11 (Tsoukala 2006). These examples show how the securitisation of immigration and of terrorism is not merely limited to security measures; securitisation discourses constitute an integral part of them. It also needs to be mentioned that, as a result of the Kurds' central role in combat against ISIS, the media images and discourses have greatly changed during recent years. One manifestation of this is the positive media visibility that Kurdish (female) fighters have received about their military combat against ISIS (Buffon \& Allison 2016; Shahvisi 2018; Şimşek \& Jongerden 2018; Toivanen \& Baser 2016). This will be discussed in more detail in later chapters.

The online space is significant for diaspora communities (Candidatu, Leurs \& Ponzanesi 2019), but it is also the place where contestations take place. One example of the contested diaspora activities is the case of the first Kurdish satellite television station, MED-TV. It was launched in 1995 by diaspora Kurds in Britain, rather than in Kurdish regions of the Middle East. The chain was granted the right to broadcast by the United Kingdom, and, although based in London, it also had offices in Brussels, Berlin and Stockholm. However, Turkey did attempt to silence the channel and accused it of being a mouthpiece for the PKK (Hassanpour 1998; Hassanpour, Sheyholislami \& Skutnabb-Kangas 2012). The EU closed the channel in 1996, claiming that it cooperated with the 'terrorist organisation' PKK. In the following years, several countries withdrew broadcasting rights from MED-TV (and its successors, Medya-TV and Roj-TV) under diplomatic pressure from Turkey (Hassanpour 1998; Sinclair \& Mets 2014).

Hassanpour (1998: 53) has argued that the launching of the first Kurdish satellite television channel opened a new site of conflict between the Kurds and the Middle Eastern states that rule over Kurdistan' and 'changed the theatre of war in favour of the 
Kurds. The online space still continues to be central in how contestations play out. Romano (2002) has examined ways that Kurds living in the diaspora have been able to organise demonstrations, discuss politically sensitive topics and distribute banned publications in Turkey. The new technologies have been significant in this regard, as they have helped diaspora members to overcome barriers otherwise existing in different parts of Kurdistan. At the same time, it has become easier to track politically active members via new technologies.

\subsection{Kurds in France}

Immigration to France rapidly increased in the post-Second World War years, namely from its (former) colonies, including Algeria and Vietnam. Over the next decades, the country actively recruited labour migrants from North African countries (Morocco, Tunisia), Portugal, Spain and Turkey (including persons of Kurdish background), aiming to meet the growing demands on the labour market. The country also became the destination for refugees fleeing from Hungary and Eastern Europe. The so-called trente glorieuses (glorious 30 years), extending from 1946 till the mid-1970s, witnessed significant economic growth and increase in the number of foreign nationals in France, until the oil crisis slowed immigration influx considerably in 1973 (Khayati 2008: 118; see also Castles, de Haas \& Miller 2014; Van Mol \& de Valk 2016: 32-36).

In contrast, the 1980 s and 1990s were marked by family reunification and the arrival of an increasing number of forced migrants. Although the number of migrants of the total population remained around 5\% from 1970 till 2000, the new migration waves brought about ethnic diversification of the immigrant population as well as, through family reunification, the arrival of an increasing number of women (Khayati 2008: 119). In 2016, the largest migrant groups by country of birth came from Portugal, Italy, Spain, other EU countries, other countries of Europe, Algeria, Morocco, Tunisia, other countries of Africa, and Turkey (Insee Population 
Census 2016 ${ }^{51}$ ). In 2018, the percentage of individuals who were born outside France (including French nationals) amounted to $12.3 \%$ of the entire population (Insee $2018^{52}$ ). In 2015, the size of the second generation (defined as having at least one parent born outside France) was 7.3 million individuals, representing $11 \%$ of the total population. ${ }^{53}$

The Kurdish community in France is among the largest in Europe, after Germany. Based on the estimate by the Kurdish Institute in Paris, some 230,000-250,000 Kurds lived in the country in 2016, although it is hard to estimate their accurate number as the French state does not collect statistics based on mother language or 'ethnicity'. It is also estimated that approximately $80 \%$ of Kurds in France originally come from Turkey, with smaller communities originating from Iraq, Iran and Syria (Kurdish Institute 2016 ${ }^{54}$ ). The generational dynamics of the Kurdish diaspora in France has been discussed in few studies (Karagöz 2017; Mohseni 1999, 2003), including in master's theses (Adam 2017; Karim 2016). The Kurdish population in France is mostly concentrated in the Île-de-France (Paris region), in Alsace, Lorraine and Bouches-duRhône, with smaller communities across the country. Kurdish labour migrants started arriving in France in the late 1950s and in increasing numbers in the 1960s, when France and Turkey signed a deal for labour migration in 1965. The 1970s witnessed the migration of Kurdish families to France, which then increasingly turned into the migration of asylum-seekers in the 1980s, thus following the general migration trends towards the continent (Werdî 2006 55 ).

Indeed, before the 1980s, Kurdish migration was mainly characterised by labour and family migration. The 1980 coup d'état in Turkey was followed by harsh repression towards the leftist groups, including the Kurdish movement, which led to many politically active Kurds exiling the country and finding refuge in European countries. Although the increase in the number of asylum-seekers was partially due to the instabilities in the region of Kurdistan, Wahlbeck (2007: 444) also states that the increase in the number of refugees can be largely traced back to the changing 
immigration policies in European countries. Kurds who now arrived as asylum-seekers would have previously been able to arrive as labour migrants. This means that the underlying motivations to leave Turkey, for instance, do not necessarily reflect the official status with which Kurdish migrants arrived in France.

The participants and their families in this study had mostly arrived during the 1980s and their migration motivations were traced back to the political circumstances in Turkey. For instance, the violent conflict between the Turkish state and the Kurdish movement in the 1980s was stated as one of the main migration motivations (Hassanpour \& Mojab 2005). Few family members had arrived for economic reasons, although in many cases these two aspects were not easily distinguishable from one another. As Wahlbeck (2007: 444) notes concerning Kurdish migrants, ' $\mathrm{e}$ ] conomic and political factors are always intertwined, and both factors have influenced both the early labor migrants, as well as the later asylum-seekers'.

This also means that the reception and the settlement take place in different legal and political frameworks vis-à-vis the state depending on whether the family members arrived with the status of asylum-seekers or as labour migrants. State policies regarding migration and integration, and notions of citizenship and national belonging, shape migrants' experiences of settlement and the formation of diaspora communities. In the following sections, I will briefly discuss French integration policies and how those relate to the understanding of national belonging and to the notion of citizenship. Following that discussion, I will discuss the ambivalence towards pro-PKK activism in the French context.

\subsubsection{Becoming citizens of the republic}

The integration governance structures have changed significantly over the past decades in France. From 1965 till 2007, integration programmes were under the responsibility of the Social Affairs Ministry. Since 2007, integration policies have been led by the Interior Ministry, and since 2009 by the OFII, the French Office 
of Immigration and Integration (Office français de l'immigration et l'intégration), which operates within the Ministry. Before 2009, immigrant integration policies were limited to five years after a migrant's arrival, after which integration was addressed by the Agency for Social Cohesion and Equal Opportunity (l'Agence pour la cohésion sociale et l'égalité des chances, Acsé) via areabased general policies that targeted disadvantaged neighbourhoods. Also, from 2007 till 2010, the Ministry of Immigration and National Identity took charge of immigrant integration, before it became the competence of the Interior Ministry. In 2007, alongside the establishment of a new ministry, President Sarkozy also introduced a Reception and Integration Contract, CAI (Contrat d'accueil et d'intégration), which immigrants sign upon their arrival. It strongly links integration to reception as it establishes a contract between the French authorities and the newly arrived migrant. This contract still exists and is managed by the OFII.

French politics during the post-Second World War decades towards 'managing diversity' have been long characterised by a toleration of difference or even political indifference that has emphasised migrants' assimilation in France (Brubaker 2001: 535-537; Kastoryano 2002). In this sense, France has often been contrasted with its neighbour, the United Kingdom, where politics of cultural pluralism (or multiculturalism) have been based on the recognition of minority cultures and communities. In contrast, on the other side of the Channel, the concept of minority is completely missing from French law. For instance, France collects national statistics on the basis of citizenship, not ethnicity, language or place of birth, ${ }^{56}$ unlike several other countries in Europe. There is, indeed, a legal impediment against the collection of data on the basis of one's ethnicity.

Since the 1980s, the policy attitudes in France have gradually shifted towards 'the right to be different', as put by Kastoryano (2002: 4) and particularly towards the institutionalisation and management of difference. One example of this is the relaxation of laws by the Socialist government in 1981 that gave foreigners' associations the right to organise on the same basis as French 
associations, via simple declaration (Geddes 2003: 69). EscafréDublet (2014) notes that French integration policy continues to be largely based on private initiatives, including NGOs that are involved in humanitarian relief and those that specifically focus on immigrants. She further states: 'However, the French institutional structure greatly influences the work of associations and the ability of immigrant-based organisations to defend their interests' (p. 5; see Ireland 1994). Concerning migrant organisations, the discussion has mainly drawn from the perceived incompatibility between, on the one hand, the French nationhood and republic, considered indivisible and united, and, on the other hand, the existence of linguistic, ethnic, religious and other communities within its political body. Indeed, the suspicion towards multiple allegiances and towards participation in ethnic-identity-based political action have coloured the French debates on citizenship and immigration since the 1980s (Brubaker 1992; Kastoryano 2002; Silverman 1992).

What stands out in the French case is how citizenship dominates over the ethnonationally premised notion of nationality. This emphasis on civic belonging is manifested in the discourses and emphasis put on integration, that is, on assimilating migrants into the political body of the French nation. The notions of nationhood, citizenship and belonging are also closely intertwined and manifested in national institutions such as schools and administration. For instance, language instruction is provided for newly arrived migrants' children through initiation classes for them to be able to join mainstream classes as quickly as possible, but the authorities are usually reluctant to offer minority language education to migrants' descendants (Escafré-Dublet 2014: 1). The French republican idea of nation considers education to be at the forefront of making French citizens, with school being the prime site of integration. For instance, Freedman (2004: 131) observes that:

State schools have always played a role as both instrument and expression of a politics of national identity which aim to detach 
individuals from their particular community or group of belonging and to assimilate to the vast collective community which is the French nation.

During recent decades, the growing number of Muslim populations in France and the debate on the 'problem' of integrating them into French society has brought the issue of religion into public discussion. In particular, the discussion on Muslim women and their wearing headscarves (hijabs) in public institutions, namely at schools that according to republican principles ought to remain secular, has been quite heated in recent years (Lettinga \& Shaharso 2009). Secularism and the removal of all religious observances are at the heart of this state-led approach, which also reflects the notions of citizenship, nationhood and belonging that have long-standing historical roots traceable back to the French Revolution and even before (Asad 2006; Brubaker 1992: 35-49).

Going back to the period of Enlightenment, the French Revolution constituted a major event towards the institutionalisation of modern citizenship as we know it today, as it became attached to a nation-state and to common (political) rights. The understanding of citizenship in France is based on a universalist understanding of membership to the French state. This goes hand in hand with the understandings of nationhood, which is state-centred and assimilationist in nature. This means, in other words, that belonging to the French nationhood is based on belonging to a political community that is enforced through culturally assimilationist measures and policies. For instance, Brubaker (1992: 1) states that: 'Yet while French nationhood is constituted by political unity, it is centrally expressed in the striving of cultural unity. Political inclusion has entailed cultural assimilation, for regional minorities and immigrants alike.' In short, the understanding of French nationhood and citizenship is strongly based on unitarist, universalist and secular elements.

French nationhood and notions of citizenship differ from the case of Germany, for instance in the sense that it has a strong territorial component, visible in the country's naturalisation laws. 
The French notion of citizenship includes very strong components of jus solis, that is, citizenship determined by the 'right of soil', which automatically provides individuals born on French soil with French citizenship (Brubaker 1992: 75-84). This is often contrasted with the principle of jus sanguinis ('right of blood'), meaning that citizenship is acquired through the nationality or ethnicity of one or both parents, as has long been the case in Germany, for instance. Brubaker (1992: 3) mentions that 'the statecentered, assimilationist understanding of nationhood in France is embodied and expressed in an expansive definition of citizenship, one that automatically transforms second-generation immigrants into citizens, assimilating them - legally - to other French men and women'. Indeed, France has long traditions of citizenship based on territorial belonging, as it has for more than a century now defined second-generation members automatically as citizens.

\subsubsection{The ambivalence towards Kurdish diaspora politics}

There has been a growing ambivalence concerning pro-PKK political activism in France, which can be understood - at least partially - against the backdrop of French state's suspicion towards migrants' political action, as previously discussed (see Silverstein 2004). In the mid-1990s, the organisation's members completed a series of coordinated attacks on Turkish consulates, including a hostage situation in the Turkish consulate in Marseille (Mickolus \& Simmons 1997: 427), leading the country to close the organisation's branches in its territory. However, it was not until 2002, in the wake of 9/11, that the organisation was designated an international terrorist organisation by the US and the EU. As Casier (2010) describes, ever since its designation as a terrorist organisation, the PKK has struggled to gain political legitimacy as a representative of Turkey's Kurds.

The discussion on terrorism has been long present in French society, but it took another turn in the 2010s with the rise of ISIS in the Middle East and particularly after the attacks in France. 
Shortly after the terrorist attacks by members of Al Qaeda against the newspaper Charlie Hebdo in January 2015, the prime minister, Manuel Valls, declared that France 'was in war against terrorism' (Le Monde 2015 ${ }^{57}$ ). However, the security measures that were reinforced after his declaration had already been in place for decades. One of them concerned the famous 'fiche S' (security file), which makes reference to individuals who potentially represent a threat to the 'state's security' ${ }^{58}$ After the attacks of November 2015, Valls confirmed that in total 20,000 individuals had a 'fiche S', of whom some 10,500 had connections to Islamic movements and other organisations considered terrorist, including members belonging to the PKK (Le Figaro $2016^{59}$ ).

As far as Kurdish associations and their members in France are concerned, after 2008 and until 2014-2015 the security measures were more forcibly applied. A lawyer who works at the bar in Paris on cases of PKK activists who have been prosecuted on terrorism charges $^{60}$ noted that after 2008 such measures have included at least 22 police operations against Kurdish individuals and Kurdish associations as well as 256 arrests, including dozens of indictments and prosecutions. Most of these cases seem to concern 'the participation to a terrorist organisation and funding of such. The same lawyer also suggested that there is a policy of mistrust visible in the rejection of citizenship requests and in the reluctance of prefectures to renew residence permits of politically active Kurds. The reason for this in the official papers is cited to be: 'your loyalism towards our institutions and our country is not guaranteed.'.1

One notable case took place in early 2015, when 10 Kurds were accused of having financed the PKK and were condemned under antiterrorist legislation. The Court of Appeal also condemned the Kurdish People's House (la Maison du peuple kurde) in Marseille for collecting funding (Le Monde 2015 ${ }^{62}$ ). In 2012, Adem Uzun, a member of the National Congress of Kurdistan's executive board, was placed under arrest for the 'financing of terrorism'. Shortly after, he was charged with trafficking of arms, before the charges were withdrawn in 2014 following a decision by the Court of Appeal (Boon-Kuo et al. 2015). His lawyer, Antoine Comte, 
declared in the French press that 'It was also a worrying procedure where the French police succumbed to the political pressure by the Turkish services' ${ }^{63}$ (20 Minutes $2016^{64}$ ). Another example of the intrusion of Turkish sovereignty into Europe was the case of the French operator Eutelsat, which suspended the broadcast of two Kurdish channels following a request by the Turkish authority, RTÜK. After a loud reaction by the Kurdish community, this decision was overturned by a decision made by the Commercial Court in Paris in November 2016 (Le Monde 2016 ${ }^{65}$ ). The role of the Turkish secret services was also invoked by a French investigation concerning the assassination of the three Kurdish activists affiliated in Paris in 2013 (Marchand 2017), as later discussed. Overall, the judicial cases and police operations against the Kurdish associations and their members have spurred lively reactions on behalf of the Kurdish communities in France and taken the form of petitions, political action and calls for authorities.

This chapter has provided contextualisation for the Kurdish diasporic mobilisations in Paris in the 2010s and will hopefully allow a better understanding of the context in which diasporic claims were made, to whom they were potentially addressed, and what narratives and discourses were employed to that effect. That will be the focus of the next chapter. 
PART III

\section{Mobilisation and Participation towards Kurdistan}





\section{CHAPTER 5}

\section{Mobilising in Paris}

\subsection{Introduction}

The 2010s were characterised by increasing political instability in the Kurdish regions in the Middle East and Turkey. The outbreak of the Syrian civil war in 2011 was followed by the rise of ISIS, namely in Iraq and Syria, where it unsuccessfully attempted to invade the renowned Kurdish city Kobane in 2014. In Turkey, the fragile peace negotiations between the state and the Kurdistan Workers' Party (PKK) were interrupted in 2015, and political tensions mounted in the Kurdish regions, leading to sporadic armed clashes between the two protagonists. Outside the Kurdish territories, the assassination of three Kurdish activists in Paris in 2013 by a perpetrator allegedly affiliated with the Turkish secret services sent waves of shock across the Kurdish community in Paris and beyond.

This chapter provides an analysis of the mobilisation by the Kurdish diaspora community in Paris in the 2010s following these events. Firstly, it discusses two major events that became visible in the diasporic mobilisation and examines the nature and means for transnational actions that followed those events. The latter part of this chapter discusses the context of political ambivalence in which the diasporic mobilisation took place. This 'ambivalence' is rooted in the simultaneous listing of the PKK as a 'terrorist organi- 
sation' and the cooperation between the Western allies and the Syrian democratic forces, closely affiliated with the PKK, against ISIS. As discussed in more detail later, these events also resonated among second-generation members previously more detached from 'homeland' realities and events.

How did the Kurdish diaspora communities in Paris mobilise in the 2010s? What events sparked mobilisation and what repertoires of local and transnational action did they entail? The three analysis chapters that follow are based on the collected material, including interviews with first- and second-generation diaspora members and non-diaspora activists, observation in diaspora activities (political meetings, demonstrations, informal get-togethers and cultural events) in Paris, and the related online material (see Appendix: Methodology).

\subsection{Violence Far and Close}

In the 2010s, the Syrian civil war spilled over the state borders into Iraq and led to an increasing instability in the region. Simultaneously, Turkey witnessed growing political unrest and spiralling violence, further destabilising the geopolitical situation in the region. The Kurdish-speaking population, dispersed between Iraq, Turkey and Syria, was touched by the ongoing conflict on several fronts. The Kurdish combatants of the Iraqi Kurdish semiautonomous region in northern Iraq (peshmergas) participated in the battle against ISIS with a coalition of international troops. The Kurdish military troops in northern Syria (YPG) and its female battalion (YPJ) combatted the organisation in the outskirts of the territories controlled by the Syrian Kurdish forces. The latter also managed to carve out a de facto autonomous region for itself in northern Syria, called Rojava. On the other side of the SyrianTurkish border, the end of peace negotiations in June 2015 between the $\mathrm{PKK}^{66}$ and the Turkish state marked the beginning of a new cycle of violence in south-eastern Turkey. In Paris, three Kurdish activists were assassinated in January 2013, suddenly bringing the 'homeland' conflict closer. These events fed into the ongoing 
mobilisations that were already under way, as described by one interviewee active in the PKK movement:

The mobilisation was already taking place. There were a lot of students who joined us after the assassination of our three comrades. It really created a shock and they realised the importance of being involved.

In the 2010s, Kurdish diaspora communities in France were mobilised and diaspora members descended onto the streets following events taking place in Kurdistan and in France. For instance, Karagöz (2017) describes the Kurdish diaspora mobilisation and the evolving forms and strategies undertaken by diaspora actors in Marseille in the early 2010s. Similarly, Kurdish diaspora actors in Paris engaged in several initiatives and activities that attracted and were targeted at both diaspora members and non-Kurdish audiences. Some were part of a series of activities that are organised regularly, usually annually. One such activity was the demonstration to call for the liberation of the Kurdish leader, Abdullah Öcalan, organised for mid-February, around the date he was arrested in 1999. However, new activities have also seen daylight, including World Kobane Day or the commemoration event for the three assassinated Kurdish activists. I will examine these activities in detail in the following section, after having discussed a series of different critical events around which many of the new activities focused.

Indeed, a series of different events fed into the waves of diaspora mobilisation within a relatively short period of time in the 2010s. When discussing mobilisations with research participants and what had spurred them to engage in different activities, certain events were often mentioned as significant ones sparking mobilisation. Table 1 below shows a chronological timeline of different events that were referenced in the material. I will not go through each of these events in detail, as more information can easily be found on them from several sources. ${ }^{67}$ Suffice to say that these events are inscribed in the political 
Table 1: Chronological timeline of events referenced in the material.

\begin{tabular}{|l|l|}
\hline \multicolumn{1}{|c|}{ Year } & \multicolumn{1}{c|}{ Event } \\
\hline 2011 & $\begin{array}{l}\text { Creation of the autonomous region of Rojava in } \\
\text { northern Syria }\end{array}$ \\
\hline 2013 & Assassinations of three Kurdish activists in Paris \\
\hline 2013 May-June & Gezi protests in Istanbul \\
\hline 2014 August & $\begin{array}{l}\text { Massacre of Yezidi Kurds by ISIS at the Şengal } \\
\text { Mountain in Iraq }\end{array}$ \\
\hline $\begin{array}{l}2014 \text { September }- \\
\text { 2015 January }\end{array}$ & Siege of Kobane by ISIS \\
\hline 2015 June & General elections in Turkey \\
\hline 2015 July & $\begin{array}{l}\text { Bombing in Suruç, city in south-eastern Turkey, } \\
\text { by ISIS members }\end{array}$ \\
\hline 2015 summer & Curfews in Kurdish cities in Turkey \\
\hline 2015 October & Ankara bombings by ISIS members \\
\hline 2015 November & General elections in Turkey \\
\hline 2015 November & Paris attacks by ISIS members \\
\hline 2016 summer & $\begin{array}{l}\text { Rojava Bureau of Representation is founded in } \\
\text { Paris }\end{array}$ \\
\hline 2016 November & $\begin{array}{l}\text { The presumed killer of the 2013 assassinations } \\
\text { dies in a Parisian hospital; case declared closed in } \\
\text { January 2017 }\end{array}$ \\
\hline Ongoing & Court cases against Kurdish activists in France \\
\hline
\end{tabular}

instabilities in Turkey (Gezi protests, curfews in Kurdish cities, suicide bombings in Suruç and Ankara, general elections), the Syrian civil war (creation of Rojava, siege of Kobane) and the situation in the Kurdish regions in Iraq (genocide of Yezidis, rise of ISIS). Furthermore, the list includes events that had taken place or were at the time happening in France (assassination of three activists, attacks in Paris by ISIS, founding of Rojava Bureau of Representation, death of the assumed perpetrator in a Parisian hospital, and court cases against Kurdish activists). These events were referenced in relation to the ongoing situation in Kurdistan, particularly in the Kurdish regions in Syria and Turkey. 
The fact that Kurdish diaspora communities have mobilised around certain issues and in the aftermath of violent events taking place in Kurdistan is nothing new. Indeed, there is a long history and tradition of political mobilisation in the Kurdish diaspora to draw attention to the situation of Kurds in their homeland (Baser 2015a; Wahlbeck 1999; Sökefeld 2006; Østergaard-Nielsen 2003), including in France (see Khayati 2008; Rigoni 1998). Concerning the long history of conflicts in the Kurdish regions and how they sparked mobilisations in the diaspora, one interviewee observed that:

Unfortunately, the Kurds are mobilised when there's blood ... In times of peace it's hard to mobilise people but in times of war people are present. The blood mobilises people, unfortunately so.

This resonates with Gourlay's (2018: 26) argument on how, in times of trauma, Kurdish identity (Kurdayetî) becomes more pronounced. Although focusing on the manifestations of pan-Kurdish identity in the Kurdish territories, his observations are also valid in the diaspora context. He also notes that this has been particularly true in recent years, when ISIS has aimed to conquer Kurdish-held territories. However, certain aspects set the 2010s mobilisations qualitatively apart from previous ones. The first was the fact that the mobilising events took place both in Kurdistan and in the host society, and the second that these events received unprecedented international media attention. Also, this time the Kurdish troops fought against a common enemy, which increased the level of international solidarity and political legitimacy for Kurdish political actors, compared, for instance, to the international response to Turkey's invasion of Afrin in 2019. One first-generation interviewee mentioned how the events that followed one another in the 2010s, especially in the context of the Syrian civil war, had an impact on the public opinion in an unprecedented manner:

Kobane had a huge impact, the war in Syria had a huge impact, the events in Turkey had a lot of impact among the Kurdish population. Concerning public opinion, this war had more impact than all the wars that Kurdistan has known. 
It is also good to bear in mind the demographic composition of the Kurdish communities in Europe, meaning that it mainly originates from Turkey. This is particularly the case with the Kurdish community in France, where around $80 \%$ of Kurds migrated from Turkey. Indeed, Grojean (2015: 53) has pointed out that the majority of Kurdish diaspora mobilisations in Europe are initiated by Kurdish diaspora communities from Turkey. One reason for this, as will be discussed later on, is the dominance of pro-PKK associations and networks that hold a significant power of mobilisation.

At the same time, it seems important not to analyse mobilisations and diaspora activism as taking place in one particular national context but to see how their dynamics play out in the transnational space. For instance, the transnational dimension of the Kurdish diaspora space was evidenced by the statement of one interviewee, who said that the demonstrations for Kobane were organised and attended by Kurds coming from Turkey, with only some tens of Kurds from Syria participating in them. He concluded that it was ironically the Kurds of Syria who had made the 'Kurdish cause' visible, whereas those who mobilised in France (and elsewhere in Europe) were the Kurds from Turkey. Another example illustrating this transnational dimension of the conflict was how the events listed above were seen as being the result of the same geopolitical struggles and conflicts across the Kurdish regions regardless of the fact that they were taking place within the boundaries of different nation-states, including in Syria, Turkey, Iraq and France. This also resonates in AnneSofie Schøtt's (2021 forthcoming: 226-228) study on the Kurdish mobilisation in Denmark. She observes that, for Kurds who are not originally from Syrian Kurdistan, the Kobane siege gave birth to 'alter-territorial identification'. This, she suggests, is based on deterritorial solidarity with the transnational Kurdish community and a reorientation towards another part of homeland from which diaspora members originate from. She concludes that the political visions of Rojava revolution and of an independent 
Kurdistan in northern Iraq have provided basis for such alterterritorial identification.

This speaks volumes to the transnational dimension of the Kurdish territories in the Middle East, as well as that of the Kurdish diaspora communities outside it. As said in the previous chapter, the Kurdish nation is a transnation in the sense that its members foster and maintain cross-border networks, linguistic and religious affiliations, familial ties and so forth that transcend the nation-states' borders both between the Kurdish communities settled outside Kurdistan and between those within the geographical area of Kurdistan. The mobilisations that came about as reactions to the events taking place in Kurdistan and in the diaspora highlight the significance of the transnational social field in which diaspora members are actors who 'make decisions, and feel concerns, and develop identities within social networks that connect them to two or more societies simultaneously' (Glick Schiller, Green Basch \& Szanton-Blanc 1992: 1-2).

At the same time, we need to be wary of approaching mobilisations as being undertaken by an allegedly uniform and homogeneous diaspora community. For instance, the Kurdish diaspora communities are heterogeneous and numerous political divisions are a structuring factor in Kurdish diaspora politics. Instead, it seems more fruitful to pay attention to how diasporic practices, claims and initiatives come about in the transnational space, and what sort of events trigger and inspire the formulation of such. This allows an analysis of how diaspora actors articulate claims to specific audiences and what narratives and discourses are employed to frame such claims. It also allows the identification of particular moments when the existing political divisions and pluralities are overcome - albeit only momentarily so. Before delving into such dynamics of mobilisation, I will focus on two main events that were most often referenced upon in the material. These are namely the siege of Kobane in 2014-2015, which took place in the context of the Syrian civil war, and the assassination of the three Kurdish activists, which happened in Paris in 2013. 


\subsubsection{Kobane momentum}

Kobane is one of the three cantons in northern Syria that were established in 2003 and that were at the time ruled by the Democratic Union Party (PYD). Since the withdrawal of the Syrian government forces in 2012, the PYD filled the power vacuum and declared these three cantons (Efrin, Ciziri and Kobane), located in the region of Rojava, autonomous. Since 2012, the People's Protection Units (YPG and the female battalion, YPJ) have operated as the security forces of Rojava, which is mainly inhabited by a Kurdish population but also includes several ethnic and religious minorities (Schøtt 2017).

In the background of the Kobane siege, which started in September 2014, was the rise of ISIS, first in Iraq and then in Syria. The organisation managed to invade large territories before it experienced its first major defeat in Kobane. The territorial expansion of ISIS in Iraq and Syria threatened the Kurdishcontrolled territories and both the Syrian and Iraqi Kurdish troops engaged in combat with the organisation. Then, in August 2014, the world learned about the genocidal attacks that ISIS committed against Yezidi Kurds and other religious minorities in northern Iraq. Considering Yezidis pagans, ISIS slaughtered, abducted and sold into slavery some 10,000 members of the Yezidi community (Amnesty International report $2014^{68}$ ). Approximately 40,000 to 50,000 Yezidis managed to escape ISIS troops to a mountain plateau, where the Kurdish peshmerga forces of northern Iraq, the YPG and the PKK secured a safe corridor to Syria and other parts of Iraqi Kurdistan (Eccarius-Kelly 2017: 40).

As Eccarius-Kelly notes, this mobilised Kurdish diaspora communities in Europe to collect funds for the victims of this massacre and to raise awareness of the Yezidis' situation to a larger public (see Schøtt 2021 forthcoming). Then, about five weeks after the attack on the Yezidis, in September 2014, Kobane happened. Located on the Turkish-Syrian border in northern Syria, the city was besieged by ISIS in September 2014 and subsequently liberated by the YPG/YPJ in spring 2015. The Kurdish troops also included 
PKK combatants who crossed the border from the Turkish side, defying attempts by the Turkish military to stop them.

The significance of Kobane siege can hardly be understated. It was a significant event, a turning point for the Kurdish battle against ISIS in Syria. It was the first time that ISIS experienced a major defeat and had to withdraw from previously occupied territories. It also resonated strongly in the Kurdish diaspora communities that mobilised and took to the streets of European capitals. As Eccarius-Kelly (2017: 41) observes (italics added),

Kurds in Germany, the Netherlands, France, Belgium, the UK and many other countries sponsored large-scale publicity events, pushed for the collection of funds to aid victims of violence, and initiated extensive lobbying efforts. The rescue of Kobane, or what in the end turned out to be an act of wrenching neighbourhoods of rubble from the control of ISIS, became a highly symbolic moment for Kurds worldwide ... Despite the prolonged trauma and devastation, Kurds worldwide celebrated $a$ rare and deeply symbolic victory in Kobane.

Similarly, in an interview, the representative of Rojava in Paris, Khaled Issa, stated that Kobane had become a date of reference that marked the rebirth of resistance and the willingness to resist with confidence. Furthermore, the siege of Kobane seemed to speak particularly to second-generation Kurds, as will be discussed later. It led to expressions of solidarity and support both among the Kurdish diaspora members and among local and international NGOs, other civil society actors and host society political actors. It also gave away to a wide range of activities, as detailed in the following section.

There was quickly a wide acknowledgement, support and visibility concerning the Kobane siege in Europe, compared to other battles that had been fought by Kurdish troops in the context of the Syrian civil war or even before. For instance, seminars on the situation of Kurds were organised at the European Parliament, and TV channels allocated a significant amount of time to expert interviewees discussing the siege. Several demonstrations 
took place in European capitals, drawing thousands of protesters to the streets of Berlin, London, Stockholm and so forth. In October 2014, about a hundred Kurdish protesters broke into the European Parliament in Brussels to demand international support for Kobane, following a partial occupation of the Dutch parliament in The Hague some days earlier $\left(\mathrm{BBC} \mathrm{News}^{69}\right)$. In November 2014, World Kobane Day was organised for the first time, and it has been organised in November ever since. Also, a number of awareness-raising events and lobbying of local policymakers undertaken by diaspora communities in Europe influenced the visibility of the Kurds' plight in northern Syria. One interviewee described the unity brought about by the collective action:

MT: So, did you notice any mobilisation among the Kurds in the diaspora here?

Interviewee: Of course! For instance, what I witnessed was that the demonstrations really created a unity and a mobilisation that went beyond politics. I remember being there and you could really see people that had never before been in demonstrations, you could see them there. I saw Kurds who had voted for the AK Party, the party in power, for the past 10 years. So, you really could see an enhancement for the Kurdish identity at that moment. I really think that it is a new era, a magical moment for the Kurds and that the entire world must have also seen and understood that.

The interviewee referred to people who had not previously attended demonstrations now being there, as well as to the visibility the siege received by the international press. Indeed, the siege received considerable international media visibility by major news outlets, among whom many picked up the central role of the Kurdish female battalion in the fight against ISIS (Toivanen \& Baser 2016). Kobane became referenced as the 'Stalingrad for Kurds', referring to the well-known battle of the Russian city during the Second World War. ${ }^{70}$ The Kobane siege was also widely mediatised because the international media had access to follow the siege right from the Turkish border, where the city is situated. 
Situated in the border zone between Turkey and Syria, a large number of journalists and photographers could follow and deliver up-to-date news on the ongoing battle, visible from the hilltops located on the Turkish side. The world witnessed the siege in real time via the substantial video and photographic material that the army of journalists produced during the four-month siege (Toivanen \& Baser 2016).

The mobilisation for Kobane in France followed quite closely similar trends in other European countries with major Kurdish communities from Turkey. However, one symbolically significant moment increasing the visibility and the legitimacy of the Syrian Kurdish political cause in France took place in February 2015, immediately after the liberation of Kobane. The French president, François Hollande, invited three Syrian Kurdish leaders from the Syrian Kurdish Democratic Union Party (PYD) to the Elysée Palace to discuss the future of the Syrian Kurdish region, Rojava. Naturally, Turkey objected to this strongly and criticised the French government of welcoming members representing a 'terrorist organisation'. In an interview with the journal Al-Monitor, Zuhat Kobani, the PYD foreign relations official, said the following:

The visit was made at the official invitation of the French president. All facilities were provided for the delegation to come to Paris. Our representatives told Hollande that the Kobani victory is not a success only for the Kurds but for all of Syria. They told him, 'We are also fighting against those who attacked Charlie Hebdo. Our resistance is your resistance. We must move this struggle forward. The YPG and the PYD are your friendly forces ... France wants to lead the war against IS and is seeking ways to cooperate with Rojava actors in that framework. ${ }^{71}$

Kobani referred to the attacks on the French newspaper Charlie Hebdo that had taken place a month earlier by ISIS-affiliated members, thus underlining the common enemy that France and the Syrian Kurdish forces shared. Furthermore, the meeting at the Elysée was photographed and these photos were disseminated to the media. Eccarius-Kelly (2017:43) writes that the series of photos 
were also a message to the wider European Kurdish communities signalling that the French government was appalled by the assassinations of three Kurdish activists that had taken place in Paris in 2013. She also suggests that it was also a message to Turkey as the possible involvement of its secret services in the assassinations that took place two years earlier had been invoked.

\subsubsection{The assassinations in Paris}

On 9 January 2013, three Kurdish female activists were shot dead at the Kurdish Information Center (147, rue La Fayette) in the city centre of Paris. ${ }^{72}$ One of them was the co-founder of the PKK, Sakine Cansız, and the two other activists, Fidan Doğan and Leyla Saylemez, were part of the local diaspora organisation. Fidan and Leyla were both second-generation Kurds, Fidan having arrived in France at the age of eight and Leyla having been born in Germany. Sakine arrived in France in 1998 and received refugee status. The French investigation suggested that the assumed killer, Omar Güney, had infiltrated the organisation two years earlier, and pointed to traces going back to the Turkish Intelligence Service (MİT). Laure Marchand (2017) provides a detailed description of the assassinations and the events that followed them, also shedding more light on the possible involvement of the MİT in the killings. The judicial process against Güney was supposed to resume in January 2017, but the assumed perpetrator died of a brain tumour in a Parisian hospital in December 2016, ${ }^{73}$ leaving family members calling for justice in an unresolved case.

As Baser (2016) writes, this was a seminal moment for the Kurdish diaspora across Europe, but particularly for the diaspora community in France. The assassinations took place in the context of peace negotiations between the PKK and Turkey (Marchand 2017), thus generating an outburst of protests. The demonstrations that followed the assassinations in Paris were attended by diaspora Kurds from Sweden, the Netherlands, Germany and other French cities, but also by local policymakers, leftist groups, 
human rights actors and other advocacy groups. Three days after the assassinations, an estimated 15,000 protesters from France, but also from Germany and other European countries, gathered in Bastille Square in Paris, following calls from several diaspora associations. For instance, the CDK-F (formerly FEYKA) declared in the call to protest:

This aggression took place at a moment when discussions to find a solution to the Kurdish problem in Turkey are ongoing ... The French state bears a part of responsibility. If the perpetrators of these crimes are not found, France will be considered an accomplice. ${ }^{74}$

As was later learned, the assumed perpetrator also took part in this demonstration before he was arrested on 17 January 2013 (Marchand 2017: 55). The assassinations generated a shock in France. Seminars to claim justice for the victims were rapidly organised, including in the National Assembly. During one such event, an invited speaker mentioned that the last bullet was shot into the mouth of one of the victims, who worked as a spokesperson for the movement. ${ }^{75}$ This was interpreted as a message sent to the Kurdish communities in diaspora to keep quiet. Marchand (2017: 160-162) also describes how the address where the assassinations took place was under surveillance by the French secret service. As one interviewee said,

It was also a shock for the international opinion, for public opinion and in France, because it was after all a breach of security at the national level, not only concerning us that you could murder three people in the city centre of Paris, in an office that is monitored $24 / 7$ by the [French] secret services.

The assassinations increased mobilisation among members who had been less active before and received quite a lot of international visibility. The assassinations also evoked strong feelings among the interviewees who had taken part in the demonstrations following them: 'When the assassination took place, I also went to the big demonstration. There were tens of thousands of people, so many, 
from the suburbs.' Some preferred not to discuss it at all, and others shed light on the impact it had on the Kurdish community in Paris. One interviewee, who had indeed worked closely with the assassinated women, said the following:

The events, the assassination of my colleagues some years ago shocked many people, especially within the community, since it had been such a long time that such things hadn't taken place, and nobody expected to be killed in a European capital. So, everybody was very shocked, very sad, and the younger ones were angry. It evoked a lot of questions, within the community, concerning the security, preventive measures and shortcomings that had been put in place with time, because nobody thought that we are going to get killed in France. It's not Turkey or the Middle East, where preventive measures are taken.

The significance of assassinations taking place in a European capital, and at the heart of Paris, was emphasised. The father of one of the victims deplored, in a seminar organised to claim justice for the assassinations, that the crimes had taken place in France, of all countries, meaning that the perpetrator knew it was possible to commit them there. Indeed, the assassinations generated a shock in the Kurdish community in Paris, because the diaspora members were not used to such a threat of violence in the host society and since 'nobody thought that we are going to get killed in France, as explained by the interviewee above. As Marchand (2017: 153) notes, for Kurds 9 January 2013 signified the death of a certain France, because the country symbolised an asylum land (terre d'asile) and represented freedom to organise political activities, such as lobbying activities that were coordinated from the office at the address 147, rue La Fayette in Paris. Such feelings were visible in interviewees' accounts, such as in this one:

The case of our comrade who fell as a martyr here, it summarizes the Kurds' situation. It's exactly the same, we are not in peace here either, we are not left in peace, so we need to get involved. At least that's how I see it. 


\section{Critical events fostering unity}

Studies on diaspora mobilisation show how diaspora communities have initiated activities as a response to a series of critical events that have taken place in the homeland context (Koinova 2018; Safran 2007). Scholars have also argued that the analysis of diaspora mobilisations needs to include not only those events that take place in the homeland context but also those in the host country context (Baser 2014, 2015a; Baser \& Swain 2011; Østergaard-Nielsen 2001, 2003). For instance, Baser (2015a) shows in her study on Kurdish and Turkish diaspora communities in Germany and Sweden that diaspora mobilisation can also take place as a result of political developments in the hostland. This was also the case with the 2013 assassinations, representing at the same time an extreme example of how events in host society context can generate diaspora mobilisations. Based on the material, I suggest that homeland-host country dynamics can become conflated via critical events that touch upon both settings, and consequently shape how diasporic claims become formulated.

What is reflective of the transnational reality in which the diaspora members are embedded is the way they made sense of major events that had taken place both in the host society and in the homeland, yet which were to some extent linked to the larger geopolitical struggles concerning the Kurdish people. The fact that both the Kobane siege and the assassinations were related to the ongoing conflicts in the Kurdish territories made them all the more tangible in contrast of having been completely unrelated to the situation in Kurdistan. The social movement literature has suggested that some events are more critical than others in increasing or decreasing the levels of mobilisation. Indeed, such events have been approached as 'transformative events' that shape collective action and that can produce radical turning points in such action (Della Porta 2008; Hess \& Martin 2006; Morris 2000). One interviewee referred to the cyclical nature of mobilisations that preceded Kobane, also making reference to how certain 'events' allow the diaspora actors to 'mobilise a segment of the population' (italics added): 
Politically, ideologically, we could say that the combats are cyclical. So, I think that, in the capacity to mobilise a population, we always have cyclical periods of time that are repeated. There is always an event that allows us to channel or not, but at least to mobilise a segment of the population that is ready to get organised and to engage in the battle.

In that sense, I suggest that both the Kobane siege and the assassinations can be considered 'transformative events', turning points that increased the diaspora mobilisation and led to expressions of unity and solidarity that exceeded - albeit momentarily - the existing lines of divisions within the Kurdish communities. This, in turn, had a multiplying effect on the cycle of mobilisations by mobilising previously 'dormant' diaspora members. Shain and Barth (2003) employ the term 'dormant transnationalists' to refer to diaspora members who can become activated in the aftermath of major political disturbances in the homeland context. They categorise (2003: 452) members of mobilised diasporas into three categories on the basis of their level of engagement. Core members are the organising elites, passive members are available for mobilisation when the core members call upon them, and silent members refer to the larger pool of individuals who are not engaged in the political or institutional life of diaspora organisations but who can mobilise in the aftermath of critical events. Although this categorisation has been criticised for being too rigid and assuming that mobilisations occur in a predictable way (Mavroudi 2018), the bourgeoning research literature on the aftermath of the Arab Spring shows that it has to some extent led to mobilisation and increased participation in transnational activities among different Arab diasporas in Europe - even among the 'dormant' diaspora members (Beaugrand \& Geisser 2016; Moss 2016). Furthermore, if we are to understand this categorisation as concerning (core, passive and silent) modes of mobilisation between which different individuals can move and not individuals per se, we can say that the siege of Kobane and the assassinations of the three Kurdish activists were transformative events ${ }^{76}$ that increased passive and silent modes of mobilisation among diaspora members. 
I argue that something else also changed with these events, particularly with the Kobane siege. Besides drawing huge masses of demonstrators to the streets of European capitals, as had happened with previous mobilisations, something qualitatively different happened during and after the battle of Kobane in terms of the spatial dynamics of these mobilisations. As discussed at length earlier, the Kurdish diaspora actors have fostered dense networks and linkages across the transnational social field, and Kurdish diaspora actors have been strategically present in Brussels to lobby European institutions. For instance, Casier (2011) has examined how the Kurdish political activists have staged demands at the level of European Parliament, and argues that the extent to which the Kurdish issue has been addressed within the European Parliament is the result of diaspora Kurds' efforts and their cooperation with Kurdish politicians in Turkey. As observed in this case too, the diasporic claims were directed at the European Union, evidenced for instance by the political action taking place in the European Parliament in Brussels. ${ }^{77}$ This observation also follows that of Eccarius-Kelly (2017: 44), who notes that, during the battle of Kobane, Kurdish activism tended to engage even more with European publics, calling for the recognition of Kurdish identity and right to selfdetermination. Indeed, she (2017: 44; see Euronews 2014 $4^{78}$ ) observes the following change in diaspora activism:

Kurdish activism in the diaspora reached far beyond the customary and recognizable street-level solidarity marches and occasional military protests. Increasing number of Kurds made use of their advanced degrees to formulate online petitions that requested donations and collected funds, organized caravans of aid supplies in support of vulnerable refugees and wrote compelling op-eds or online exposés.

In other words, there seemed to be a broader change in Kurdish diaspora activism across Europe in the sense that diasporic claims were increasingly made to the European policymakers, building on the already-existing alliances and networks that Kurdish political actors had in Brussels. Indeed, new nodes of solidarity and 
feelings of unity were born out of the observation that the ongoing combat against ISIS concerned Kurds beyond the borders of Syrian Kurdistan. The combat was also framed in the media, as well as by the Kurdish political actors, as Kurds fighting against a common enemy, the latter with the aim of increasing the legitimacy of Syrian Kurdish actors in the international political scene.

At the same time, Kurdish diaspora actors were also increasingly vocal towards the national actors, particularly in the French case and, it seems, also in the Danish case (Schøtt 2021 forthcoming). What was visible in the collected material was that the diaspora actors also increasingly addressed national actors in France, particularly after the ISIS attacks that touched France in 2015, which presumably made the national interlocutors seem more receptive to diasporic claims concerning the Kurds' combat against ISIS. Indeed, diaspora actors simultaneously addressed EU-level interlocutors as well as local actors to raise awareness of the ongoing conflict. This was also visible in how diasporic claims and repertoires of action were formulated. For instance, a number of initiatives and activities attracted and were targeted at both Kurdish diaspora members and, significantly, also at non-Kurdish audiences in Europe, as in the case of assassinations (see Demir 2015). I will next discuss the observed activities undertaken by Kurdish diaspora organisations and actors in Paris, organised particularly between 2015 and early 2017, including those organised in cooperation with non-diaspora organisations.

\subsection{Means and Repertoires of Action}

Diasporas are known to engage in a great variety of transnational political activities, and the Kurdish diaspora is no exception to this (Baser 2014; Scheffer 2003; Østergaard-Nielsen 2003). The activities of Kurdish diaspora communities date back to the arrival of Kurdish migrants in Europe in the 1960s and 1970s. Therefore, some activities witnessed in the 2010s joined a longstanding tradition of organising activities by diaspora associations, including the Newroz celebrations and the demonstration 
calling for the liberation of the Kurdish political leader Abdullah Öcalan, for instance. Another, more long-standing demand was the call to remove the PKK from the list of terrorist organisations in Europe (Casier 2011). ${ }^{79}$ As far as the mobilisations in France are concerned, the 'transformative events' discussed earlier have shaped mobilisation processes and the related repertoires of diaspora activism across French cities (see Karagöz 2017). It is vis-à-vis these 'transformative events' that different diasporic claims have been articulated and framed by diaspora actors.

One approach to understand diasporas' political action is to examine the degree of institutionalisation they embody. For instance, Chaudhary and Moss (2016) distinguish between three types of immigrant transnational political action, in order from most to least institutional: electoral, organisational and noninstitutional. Loosely following this distinction between different forms of transnational political action, I have chosen first to focus on electoral, organisational and semi-institutional activities, the latter also including cultural activities with a political aim. The repertoires of action in the collected material included all three forms, although in several cases different activities overlapped. The latter part discusses different factors that have shaped such transnational political activism.

\subsubsection{Electoral transnational political action}

Electoral transnational political action refers to voting, campaigning, campaign fundraising and mobilising for or against parties or candidates in the home country (Chaudhary \& Moss 2016: 6). The most common electoral activity by diaspora Kurds in Paris included long-distance voting in the general elections that took place in Turkey in June and November 2015. In fact, it first became possible for Turkish citizens to cast long-distance votes in the presidential elections in 2014, which were followed by general elections in June 2015 and its second round in November 2015. The quick election in November was called by President Erdoğan after the June elections resulted in a hung parliament. Whereas in 
the early 2010s there seemed to be some hope of ending almost 40-year-old conflict between the Turkish state and the Kurdish Workers' Party, this hope evaporated in the summer 2015 as peace negotiations fell through and the country steered towards more authoritarian tendencies (see Baser \& Özturk 2017) with military curfews put in place in south-eastern Turkey under the auspices of the state of emergency. The general elections in 2015 took place in this context.

So how did the voting play out in the diaspora that gained the right to vote in 2014? The voter turnout for France in the 2014 presidential elections was merely $8.35 \%$, quite similar to the turnout of Turkish citizens' voting patterns in other host societies, whereas in Turkey it was $74.13 \%$. However, for the general election in June 2015 it reached $36.97 \%$ in France, among the highest in host countries in Europe, and in November 2015 it rose to $44.78 \%$ among diaspora voters; the turnout in Turkey in these elections was $86.38 \%$ and $87.40 \%$, respectively (Akgönül 2017: 133).

In both rounds of the general elections in 2015, Turkish citizens voted for the party not the candidate. Akgönül (2017: 314) observes that: 'the only two political parties that have consistently drawn large vote shares abroad are the two erstwhile "counterhegemonic" ones - the AKP and the HDP'. He also notes that it is the leaders of these two parties, ${ }^{80}$ Recep Tayyip Erdoğan and Selahattin Demirtaş, who were the only ones to hold public meetings with diaspora electors, although the contents of their speeches related to internal politics in Turkey instead of building a policy towards the diaspora electors. For instance, Demirtaş was invited to give a talk at a seminar titled 'The Crisis in the Middle East, Kurds and the Resistance against ISIS' (La Crise au Moyen Orient, les Kurdes et la Résistance contre Daesh), organised in Paris in November 2015. He also visited Marseille during the same trip (Karagöz 2017). In both cities, he addressed a public consisting mostly of diaspora members.

In 2015, the diaspora organisations aimed to mobilise their members to vote in the election, which was considered quite historical. For instance, the KDC-E (Kurdish Democratic Society 
Table 2: Vote share in diaspora and all counted votes.

\begin{tabular}{|l|c|c|c|c|c|}
\hline \multirow{2}{*}{$\begin{array}{c}\text { Political } \\
\text { party }\end{array}$} & France & Germany & Sweden & $\begin{array}{c}\text { UK } \\
\text { (London) }\end{array}$ & All votes \\
\hline AKP & $58.4(50.7)$ & $59.7(53.7)$ & $40.7(34.0)$ & $20.2(14.6)$ & $49.50(40.87)$ \\
\hline HDP & $25.8(29.6)$ & $15.9(17.5)$ & $39.1(43.2)$ & $54.6(59.2)$ & $10.76(13.12)$ \\
\hline
\end{tabular}

Congress in Europe) called for mobilisation with the statement: 'The support you gain in Europe for the HDP will deal the greatest blow to the AKP. Every single vote counts if the threshold is to be exceeded.' ${ }^{\text {'I }}$ In fact, it was the first time that the pro-Kurdish People's Democratic Party (HDP - Halkların Demokratik Partisi) passed the $10 \%$ threshold needed to enter the parliament. The voting patterns for Turkish citizens (including ethnic Turks, Armenians, Kurds etc.) located across different European countries shows that the HDP enjoyed wider support in northern Europe (Sweden, $\mathrm{UK}$ ), whereas the AKP received the large majority of votes in Germany and France during the general elections in June 2015 (in brackets) and November 2015. ${ }^{82}$

As we can see, the proportion of votes cast in the diaspora, particularly for the HDP, differed from the totality of votes, largely of course cast in Turkey. The HDP had a higher voter turnout in the diaspora than it did in Turkey, as did the AKP in France and in Germany. The Republican People's Party, CHP, was clearly a less popular choice among Turkish citizens in the diaspora. ${ }^{83}$ What was interesting to notice was the mobilisation to vote in the general elections. Indeed, quite a few respondents had voted in the general elections, many also for the first time in their lives. One interviewee explained that he had never previously voted in his life, including in French elections.

MT: Okay, so now persons with Turkish nationality can vote at distance; it hasn't been like that for a long time ...

Interviewee: It's the second vote, yes. 
MT: So how does it usually work? Are there many people who vote?

Interviewee: Yes, you go to the Turkish consulate and vote there. After the votes are sent back there, they are counted here. We went to vote for the HDP. It was a must. I have never voted before, even in France. My first vote was for the HDP, the first vote in my life.

Diaspora organisations also organised transportation possibilities for eligible diaspora members who held Turkish citizenship to come and vote at the Turkish consulate in Paris. Other activities that could be characterised as electoral included fundraising for electoral campaigns. One activity not listed by Chaudhary and Moss (2016), yet which can be characterised as electoral, was the electoral monitoring visits to Turkey that were organised via HDP offices in Brussels.

MT: So, you mentioned the electoral monitoring missions ...

Interviewee: Yes, they are organised via the invitation by HDP in Brussels, and we take care of the delegations and also send translators if needed, and then they are sent to Turkey. We have been doing this for 15 years at least, every time we sent in delegations. Each year for the elections and the Kurdish new year. When you go there for Newroz, you have the chance to meet up with the elected and to talk with them. After you participate in the party and meet associations, institutions etc.

The electoral activities were at the same time locally based in Paris, yet included a significant transnational dimension as they aimed for a change in the political landscape of the sending country. Electoral activities such as monitoring missions and campaigning can be considered a part of organisational activities, with the exception of individual voting activities. In that sense, there was no significant distinction between the two concerning the different degree of institutionalisation. However, for the purposes of clarity, I have discussed the electoral activities separately from other organisational activities. 


\subsubsection{Transnational organisational activities}

Organisational activities consist of advocacy groups, ethnic associations, charities, hometown associations and ruling party/ opposition organisations (Chaudhary \& Moss 2016). Besides Kobane, the worsening human rights situation in Turkey and the spiralling violence (namely state violence) in the Kurdish region were also often referenced in the organisations' events. The social uprisings that followed the 2013 Gezi Park protests in Istanbul, and which spread across the country amid protests originally contesting urban development plans, resonated in the diaspora (Baser 2015b: 256-257) and were also visible at the level of organisational activities. For instance, police brutality and the tightening state censorship and human rights' violations later evoked large-scale political protests both in Turkey and in European cities with sizeable Turkish and Kurdish diaspora communities.

These events, among others, were reflected in diaspora organisations' activities of a transnational and political nature, also bringing Turkish and different Kurdish diaspora groups together to collaborate (Baser 2015b: 256-257). The organisational activities also made visible the collaboration that was established between different diaspora and non-diaspora actors via organisational means. This meant, for instance, that a number of different associations organised an event to discuss the ongoing conflicts and the situation of Kurds in the region. Several seminars aimed to raise awareness, as shown below, were organised via the collaboration between Kurdish diaspora organisations, Turkish diaspora organisations, French leftish parties, student associations and French civil society organisations. This also recalled a longer history of political alliances and sensibilities among the French left towards the Kurdish question, as discussed earlier.

The most visible organisational activities were advocating and raising visibility of the situation of the Kurdish people in Turkey and Syria to local policymakers via seminars and discussion events. Organisational activities also included the establishment of proRojava solidarity groups, which created new solidarity nodes in 


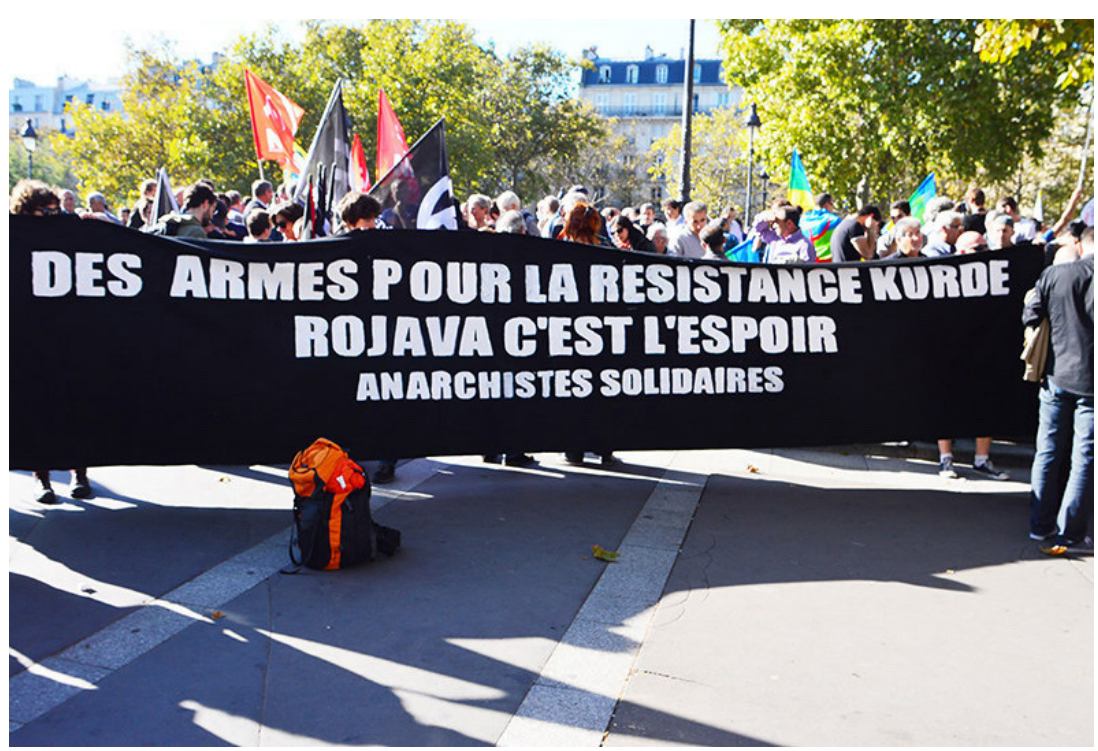

Image 1: Non-Kurdish associations mobilising in Paris for Kobane. Source: Cuervo/AL Paris-Sud. Published under CC BY-ND 2.0.

the diaspora in addition to the existing ones. Collaboration with Turkish leftist-leaning organisations became visible, for instance, in the electoral activities coordinated by Kurdish and some Turkish diaspora organisations in 2015. This observation is similar to Karagöz (2017: 96-97), who notes concerning the Kurdish diaspora mobilisation in Marseille that: 'this specific conflict has multiplied the interactions between the Kurdish activist sphere and the host society's space of mobilization'. She concludes that these extra-community links had given rise to a 'hybrid sphere of contention' and that Rojava and Kobane had a 'multiplier effect' on the emergence of such a hybrid sphere of contention between the diaspora and non-diaspora actors.

This also became evident in the observed events that took place in high-profile locations, including at the National Assembly in Paris or at the townhall of the 10th arrondissement in Paris, indicative of the networks that diaspora organisations had with non-diaspora actors. The observed events' programmes could feature political actors from the local administration of Rojava, 


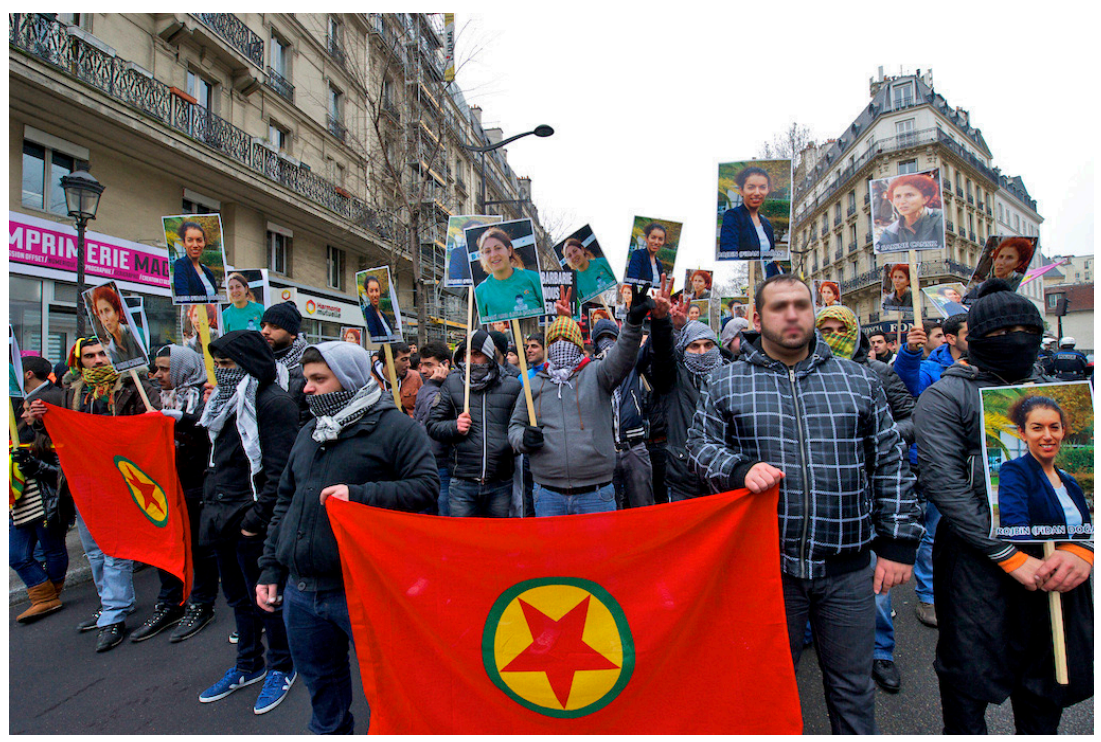

Image 2: Demonstration in Paris for the killed activists on 26 January 2013. Source: Chris Sang-hwan Jung via Wikimedia Commons. Published under CC BY-SA 2.0. Photo edited slightly at HUP to obscure faces.

activists from diaspora organisations and leaders of the HDP, as well as French policymakers from leftist parties. For instance, in the event referenced above, 'The Crisis in the Middle East, Kurds and the Resistance against ISIS', other invited speakers besides Selahattin Demirtaş included the former minister of foreign affairs Bernard Kouchner, the co-president of Rojava cantons Sinem Mohamed, and the political coordinator of the leftist party in France, Eric Coquerel. Also, the Kurdish Newroz celebration in 2016 was organised at the City Hall in Paris, on the initiative of Paris mayor Anne Hidalgo. In her opening speech, Hidalgo confirmed her support for the Kurds and the Kurdish troops fighting against ISIS. The event also included speeches from Kendal Nezan, the director of the Kurdish Institute, from the Iraqi Kurdish diplomat Sirwan Barzani and from Bernard Henri-Lévy, the French public intellectual, who made reference to an earlier discussion between Barzani and President Hollande, the latter confirming France's support for Kurds and Kurdish troops. ${ }^{84}$ 
What made these mobilisations quite different from previous ones was the extent to which non-diaspora actors came together with diaspora organisations (see Eccarius-Kelly 2017). The assassinations of three Kurdish activists and the situation in Kobane (and in Rojava more generally) received considerable visibility in France, evidenced by the photo of the three Kurdish activists in front of the City Hall, at the heart of Paris. In fact, President Hollande knew one of the killed activists (Marchand 2017: 30), highlighting the networks Kurdish actors have succeeded in establishing with high-ranking politicians in France. ${ }^{85}$ Another example of this was the visit to Rojava by the French former foreign minister Bernard Kouchner and a leader of the German party The Left, Gregor Gysi, in 2014. During the same time, a delegation of the European Parliament also visited the region. ${ }^{86}$

Also, in summer 2016, the Bureau of Representation for Rojava was opened in Paris, after the first attempt failed. Other bureaus of representation for Rojava were opened in Moscow, Prague, Berlin and Stockholm in 2016. The representative of the Rojava Bureau in Paris, Khalid Issa, stated in an interview that the Kurdish diaspora has two significant roles in France: one as a diplomatic actor between France and Rojava and the other to raise awareness. Issa also suggested that it was thanks to the diaspora's lobbying efforts in France that the country was the first in Europe to express a supporting position vis-à-vis Kobane. Indeed, it can be said that Kobane was a turning point in the representations of Kurdish combatants and their role in the armed conflict in Syria.

Such imaginaries and representations were constructed through an active media work and lobbying by diaspora organisations to increase the visibility of the Kurdish combat (see Andén-Papadopoulos \& Pantti 2013). This strategic dimension was also referred to by one politically active interviewee, who talked about how the pro-PKK movement had employed the visibility of the conflict.

In the media, it's us. We have contacts in the news agencies, not only the French ones, but also the Arabic ones and so forth. The war in Syria and in Rojava was very mediatised. It is also our 
way of showing how we engage in war through transparency. We didn't restrict the entry of journalists to the front.

Therefore, it is also important to account for the impact of pictography and media discourses in shaping sensitisation to the KurdishISIS conflict beyond the boundaries of Syrian Kurdistan. This is similar to Andén-Papadopoulos \& Pantti's (2013) observations on Syrian diaspora activists' media work. The authors analysed 'cultural brokerage' and showed how Syrian diaspora actors linked the voices of homeland protesters to the outside world, how they managed messages that bridged the gap between social media and mainstream media and how they also collaborated with professional journalists to make the stories fit for foreign publics.

A considerable amount of awareness-raising initiatives were organised in collaboration between diaspora and non-diaspora associations and NGOs. Indeed, the associative structures and networks gradually constructed since the arrival of Kurdish migrants in France played an important role in the mobilisations. The repertoires of action inscribed into a long history of Kurdish diaspora activism, as discussed earlier. Many of the observed events were organised by pre-existing associations, such as by those belonging to CDK-F (the Kurdish Democratic Council in France, grouping 24 associations across France), which had close connections to associations in the Kurdish region. However, it was noteworthy that both of these critical events gave birth to new associations, especially in the aftermath of Kobane. An interviewee tells how he and some others founded an association in one small city in France:

They became active; there are several active youths. I can say that at the moment I was in $[\mathrm{city}]^{87}$ and we founded an association during the war in Kobane. Nothing more, an association, in [city]. It means that even in [city] there was a Kurdish association, so imagine how it was elsewhere in France!

Several pro-Rojava solidarity associations were established following the siege of Kobane, also indicating collaboration between diaspora and non-diaspora actors, yet with the clear aim of raising 
awareness of the situation in the Kurdish region. Also, the assassinations in Paris gave birth to the creation of at least one association, that of the France-Kurdistan Association, in 2013. The Facebook page of the association describes the following objectives:

The France-Kurdistan Association was declared on 9 January 2013 ... created as a response to the assassinations of three Kurdish militants, Rojbin, Sakine and Leyla, in Paris. Truth needs to be known and justice served on this acknowledged political crime. ${ }^{88}$

Overall, we can say that the pre-existing Kurdish associations in Paris, several of which had close ties to the PKK, focused their organisational activities to raise awareness of the situation in Kobane and in the Kurdish regions in Turkey, while new associations also saw daylight in response to the two mobilising events discussed earlier.

\subsubsection{Transnational semi-institutional activities}

The electoral and organisational activities share a high degree of institutionalisation. Chaudhary and Moss (2016) argue that, in addition to these two, there is a need to attend to non-institutional collective action as a third category of transnational political action engaged by immigrants. By this, they refer to transnational political action that aims to affect social and political change in the homeland context (ibid.: 7), including protests, demonstrations, boycotts, petitions, covert actions, armed conflicts and revolution. I have chosen to refer to such activities as semi-institutional as they included an organisational dimension. The observed semiinstitutional activities included participation in protests, demonstrations, circulating and signing petitions, and in some rare cases there were references to participation in the armed conflict.

The semi-institutional activities are located somewhere in-between the organisational and non-institutional activities. In several cases the semi-institutional activities included an organisational component, but these differed from the organisational 


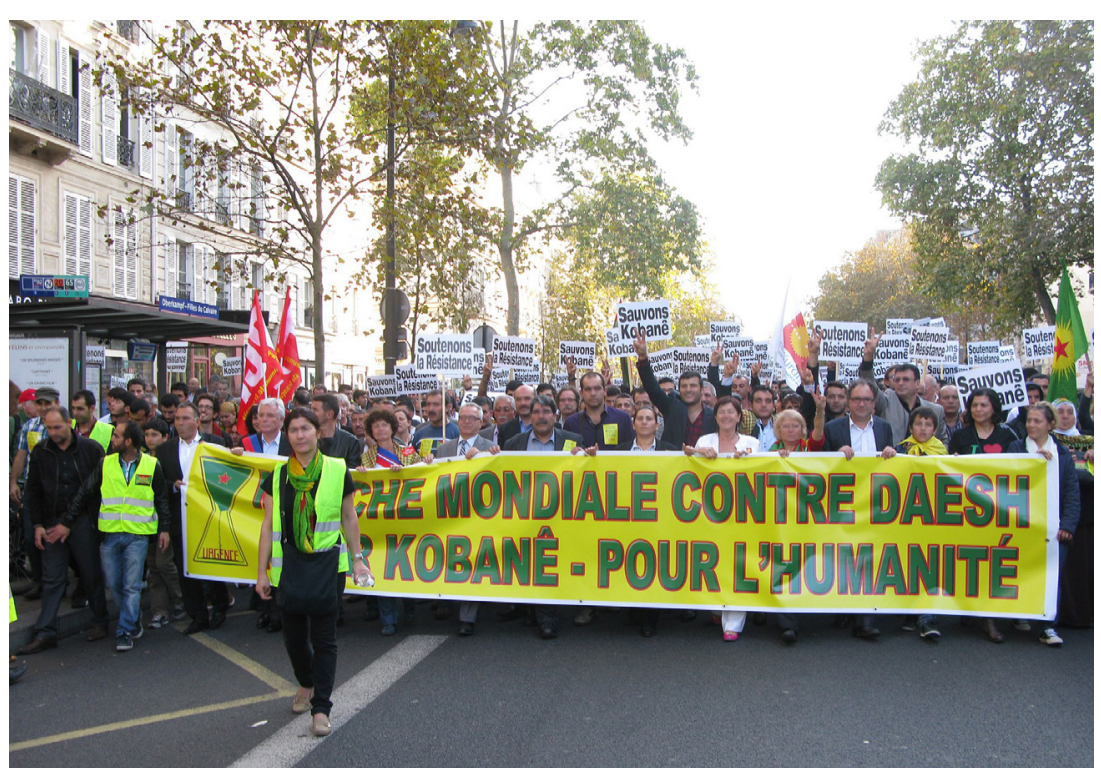

Image 3: Demonstrators marching in Paris on the World Day for Kobane, 1 November 2014. Source: Jiel Beaumadier via Wikimedia Commons. Published under CC BY-SA 4.0. Photo edited slightly at HUP to obscure faces.

activities discussed above. Seminars and discussion events organised by different associations could be characterised as organisational activities as they took place within an organisational frame: for instance, one or several associations organised a seminar and had the power to determine its focus, contents and speakers. In other words, the level of institutionalisation in transnational political activities of organisational nature was higher. Demonstrations differed from these in the sense that, even though in many cases they were initiated by associations, they were attended by and most importantly took shape through the participation of different individual actors. However, this distinction was not always clear. One example where the organisational agency became enmeshed with non-institutional individual actions was the creation of humanitarian networks to channel material and logistic aid to northern Syria. During the siege of Kobane and immediately after it, diaspora members participated in sending aid to the 
region. These initiatives were channelled through associations, such as Heyva Sor (Kurdish Red Crescent), but included a considerable amount of both individual initiatives and non-institutional collective action.

Although listed as non-institutional activities by Chaudhary and Moss (2016), demonstrations were the most common semi-institutional activities in which diaspora members took part. These included participation in massive protests, demonstrations, and petitions that circulated online; one interviewee explained:

MT: So how about activities ... So you took part in the meeting organised by [association's name]; are there other things in which you take part?

Interviewee: I really try if I have time, to participate in every demonstration and huge movements. For instance, when the three women were assassinated, I really had to participate; it was essential.

In addition to participating in large-scale demonstrations, engaging in humanitarian aid and circulating petitions, some referred to diaspora members who had joined the YPG troops to combat ISIS in Syria. ${ }^{89}$ Those returning to Europe from Syria after having fought in YPG troops were met by the local authorities with a suspicion similar to former ISIS combatants. This led to court cases in Europe, as discussed in the following part. One interviewee tells of his motivation to leave and engage in combat before finding another way to engage. In his case, an association provided an alternative avenue to get engaged instead of leaving the region.

Interviewee: Historically we are great combatants. We know that Kurds are not afraid to die. They are ready to give their lives to the cause and even beyond that. If it'll come, it'll come.

MT: Do you know many youth who left to fight with the YPG?

Interviewee: I don't know anybody personally. I know somebody from the university who left to fight. I would have wanted to leave myself too ... But when I saw [association], I engaged in that. 
Although Chaudhary and Moss (2016) mostly focus on transnational political action, I suggest that cultural activities can also contain a political dimension when they aim at raising awareness of and gaining visibility for the situation in the homeland. Discussing organisations' aims and objectives, Chaudhary and Moss (2016: 6) suggest that they may not be explicitly political but that 'their actions and impact on communities in places of origin nonetheless have political implications'. Following a similar logic, the observed cultural activities were comparable to demonstrations that aimed to raise awareness on and draw attention to the situation of Kurds in Syria. Such politically motivated, yet often framed as cultural, action included the organisation of Kurdish film festivals, photograph exhibitions, concerts, fundraising events for humanitarian projects, discussion events and seminars that clearly contained the objective of raising awareness of the situation in Kurdistan, and in some cases collecting funding for reconstruction projects, for instance. One interviewee set out the significance of cultural production in the following manner:

The cultural side contributes enormously to better understand the situation. For example, documentaries that are made from the region, sometimes they are better than books because in 50 minutes of a documentary, the viewer has understood the political project that we wish to put in place, our values, what we feel, what we wish to transmit. The work on arts and culture is as important as the political side ... You should never underestimate that ... To win over a heart is to win over a thousand hearts.

A photo exhibition that displayed Kurdish female combatants in Rojava was organised by the Kurdish Institute in Paris in late 2015. The photos were taken by award-winning photojournalist Emilienne Malfatto. ${ }^{90}$ In some cases, this political aspect was more articulated than in others. One such event was the organisation of the photo exhibition that aimed to raise awareness for the Kurds' combat in Syria. The opening words of the brochure stated that: 
The Kurdish people is at its direst moment. In Syria, Iraq and Turkey, different regimes aim at its submission. But we are convinced that never will the Kurds kneel, never will they abandon their wish for peace and for the respect of their rights. Their combat for the universal values takes place on the ground, in the first line against ISIS. Their success will equally be ours.

Such cultural activities were organised either via associations, thus evoking a (semi)organisational political action, or as private initiatives. Examples of the latter included engaging in cultural production, for instance through translating and distributing Kurdish literary texts. The content for such Kurdish cultural production frequently evoked the combat against ISIS, with a particular focus on women combatants, as shown above. Furthermore, the assassinations in Paris were often referenced and featured in cultural artefacts produced by diaspora actors, namely in the form of art exhibitions, Kurdish film festivals and books. For instance, the Kurdish film festival that took place in October 2015 dedicated the fourth edition of the festival to three Kurdish assassinated militants, to those who have made and are making the revolution in Rojava happen and to Kurdish women.. ${ }^{91}$ In addition to the assassinations, the preface also mentioned the siege of Kobane, and the fate of Yezidi women in Iraq. ${ }^{92}$ These activities all contained a rather clear political dimension as they were explicitly aimed at raising awareness of the Kurds' situation in Syria.

The cultural artefacts further contributed to solidifying the collective narrative of the Kurdish combat in Kobane against ISIS. Images drawing from the critical events were employed to construct an emotionally powerful narrative of the Kurdish struggle, which was then communicated to larger audiences. This was indeed a very efficient means to sensitise and mobilise both the diaspora and nondiaspora audiences. In that sense, we can say that they constituted an effective way to advocate and draw attention to the Kurdish struggle and operate as a more indirect form of lobbying different actors in the host society. Indeed, they constituted a part of the diasporic initiatives and claims-making that took shape through a wide range of activities in which both diaspora and non-diaspora 
actors engaged and which included different degrees of institutionalisation. On the basis of the collected material, the observed mobilisation in Paris consisted of electoral, organisational and semi-institutional activities that had a clear transnational dimension in how such activities were organised in the transnational space and how the 'homeland' was evoked in them.

\subsection{What Affects Mobilisations?}

This part specifically discusses different factors that have shaped the formulation of Kurdish diasporic claims and activities in the 2010s. In this part, I draw from the social movement literature and how that has been applied to the diaspora context by various authors. The emphasis concerning what factors facilitate or hinder mobilisation processes by diaspora communities has been on three aspects: 1) political opportunity structures, 2) how different resources (including pre-existing organisational and network structures) are mobilised and 3) how mobilising events are framed in terms of collective identity (Quinsaat 2013, 2019; Sökefeld 2006). The following parts discuss these aspects in more detail.

\subsubsection{Political opportunity structures}

One major stream of research concerning collective mobilisations, in general, seems to have been the political context, in other words the role played by the political opportunity structures (POSs). In short, this has usually meant paying attention to the openness of the political system to accommodate collective action, the presence of elite allies and the state's capacity for repression (della Porta \& Diani 2006; Giugni 2011; Meyer \& Minnkoff 2004). More recently, scholars have argued that to understand transnational activism by diaspora communities, in addition to addressing the political structures in the country of settlement, there is a need to account for those in the country of origin - and the interaction between these two (Adamson 2012; Grojean \& Massicard 2015; Sökefeld 2006; Østergaard-Nielsen 2003). Adopted 
to the diaspora context, Sökefeld (2006: 270) understands political opportunities as 'means of communication, media and transport, as well as the legal and institutional (for example multiculturalist) frameworks within which claims for community and identity can be identified', both in the host society and homeland setting. Building on this, Chaudhary and Moss (2016) suggest a triadic political opportunity approach to conceptualise how immigrants' transnational political action is shaped by 1) host country contexts (integration policies; access to local politics; co-development policies), 2) origin country contexts (authority type of governance; internal stability; diaspora policies) and 3) transnational political opportunity contexts (supranational institutions; international legal regimes; bilateral relations; foreign policy).

The first aspect is the host society context, which has traditionally been considered to provide more space in terms of political organisation and greater liberties for political mobilisation (Østergaard-Nielsen 2003). Integration policies and access to receiving country politics have been considered to be rather open in France (MIPEX 2015 ${ }^{93}$ ), although migrants' political activism has met with suspicion from the French authorities (EscafréDublet 2014: 5). Based on the overall material, however, it can be said that the country's political system is open to protests and lobbying, and the institutional and policy environment in general is not opposed to Kurdish diaspora actors' political claimsmaking. Also, Giugni and Passy (2004: 51) note that the 'civicassimilationist conception of citizenship in France gives migrants greater legitimacy to intervene in the national public space. However, there were also instances in the overall material when the political activism had negatively affected the granting of citizenship and residence permits. For instance, one interviewee told of the situation in which her mother had been for years:

For instance, my mother has been in this country since the 1980s, she's been working here for 30-40 years, she has always paid her taxes ... She has made five requests to have the citizenship and they have all been refused due to her political opinions. 
Indeed, there have been some limitations concerning particularly pro-PKK political activism in France that have affected the granting of citizenship or a residence permit. This will be discussed further in the following section.

Another aspect that has been tackled in the POS literature concerning diasporas is the origin country context (Chaudhary \& Moss 2016). We can say that the origin country context - that is, Turkey - steered towards more internal instability when the peace negotiations came to an end in 2015. In that sense, the transnational political action observed during that time was fuelled by the ongoing situation in Turkey, particularly in the Kurdish regions. Also, diaspora engagement policies in the form of electoral rights also concerned Kurds who held Turkish citizenship, but they were likely directed to Turkish constituents in the diaspora. In that sense, the origin country POSs have not facilitated Kurdish political mobilisations in the diaspora, particularly those sympathetic to the PKK. On the contrary, there is plenty of evidence of the intrusion of Turkish sovereignty into the European space with the aim of limiting pro-PKK Kurdish activities, as discussed in Chapter 4.

Thirdly, there are the transnational political opportunity contexts, such as supranational institutions, international legal regimes, bilateral relations and foreign policy, which shape the diaspora's transnational political activism (Chaudhary \& Moss 2016; Ögelman 2003). The observation on the significance of transnational POS is made by Østergaard-Nielsen $(2001,2003)$ in her earlier studies on Kurdish political action in Germany and the Netherlands. She argues that, in addition to the political institutions in the sending and the receiving state, global institutions and networks of other non-state actors (including the NGOs) are also significant in shaping how migrants can engage in transnational political practices. For instance, Baser (2011) discusses how numerous civil society organisations are used to raise awareness of the Kurds' situation in Turkey. Based on the overall material, we can say that, together with the host society context, the transnational POSs, including particularly NGOs and the tradition of appealing to European 
political institutions (Casier 2011), have been quite enabling in terms of the observed political mobilisation.

\subsubsection{Mobilising structures and practices}

Besides POSs shaping collective action in the diaspora, Sökefeld (2006) also refers to mobilising structures and practices as a second strand in the literature on social mobilisations. By this, he refers to networks via associations that can be of a transnational character and that affect diaspora mobilisations. They are, according to him, 'networks of people that are bound to the same issue or formal organisations that are established for the purpose of making particular claims' (Sökefeld 2006: 269). As previous studies have shown, the transnational diaspora space, including the multiple networks between associations, is significant for the political mobilisation of Kurdish communities (Khayati 2008; ØstergaardNielsen 2001, 2003). These networks have a significant online dimension, as also referenced by the interviewee below.

They were mobilised for Kobane. Since I have worked with Kurds, they are more and more mobilised. Even if it is hard for them, because not all speak the language, you have contacts, political networks and the Internet also plays a role.

These are the words of an activist who had founded a solidarity association supporting the Kurdish issue but who nevertheless was not of a Kurdish background. The activist also refers to the importance of networks, both local and transnational, that were essential in the mobilisation processes. As discussed in earlier chapters, the transnational contacts between the diaspora actors and between political actors in the societies of departure constitute extensive networks that transcend the nation-states' boundaries. For instance, the demonstrations for Abdullah Öcalan's release are organised and even take place in the transnational space, in the sense that the demonstrations organised in Paris, for instance, are attended by diaspora Kurds from Germany, the 
United Kingdom and elsewhere. This has also been the case for World Kobane Day since it was first organised in 2014 in different European capitals. Both events have attracted thousands of Kurds to the streets. They also have another common denominator, as explained by this interviewee (italics added):

MT: When you talk about politicization, was there a difference after Kobane, for instance?

Interviewee: For the mobilisation, as you know, it can be at times a bit artificial. It touches people's hearts when you see Kobane being sieged by ISIS, and then there was Turkey ... Kurds who wanted to cross the border to help their brothers and sisters that were sieged and were not allowed to do so. So, it touched everybody, in my opinion ... But in the end, the Kurds in Europe, they are mobilised via the PKK that can for sure unite hundreds of thousands of people in a day.

The interviewee refers to the mobilising power of the PKK. The PKK, which is the best-known Kurdish organisation, has transformed from a military organisation in the 1990s to become a political and social movement that enjoys a significant mobilising power and transnational networks in the diaspora (Jongerden \& Akkaya 2016). One interviewee, active in a pro-PKK organisation, refers to the organisational and political culture that has mobilising power vis-à-vis the diaspora community and which has been actively developed since the 1980s:

In the early 1980s, and till the end of 1990s, what was created and what is today the network we have, the diaspora's network that is well structured, everywhere and numerous, it needed a lot of sacrifice since the beginning. If it hadn't been done in the beginning, during the tough times, it wouldn't have been possible to get organised. Today, when the tensions calm down, a certain passivity will settle. That's why we have the organisational culture, a political culture that makes the diaspora move and act all the time. So even when there are times when it seems passive, we manage to make the diaspora dynamic and move. 
In fact, Grojean (2015) goes as far as to suggest that the situation of Kurds in France (and in Europe), the 'integration' of Kurdish migrants, asylum or immigration policies, or even the POSs in France, Germany or Great Britain have little to do with how the Kurdish diaspora communities mobilise. Instead, he argues that the mobilisations in the diaspora are the result of the transnationalisation of similar mobilisations taking place in Turkey. In this regard, he notes that the PKK has a central role in the processes of mobilisation that take place in Europe, namely via the organisational and political cultures, as also referenced by the interviewee above. He further notes the importance of paying attention to the role played by pro-Kurdish political organisations, to significant events of the conflict concerning Kurds in Turkey and to the foreign policies of different European countries towards that conflict.

How such networks are employed for the purposes of mobilisation is, for instance, via transnational political actors. Adamson (2013), who has studied the mechanisms of diaspora mobilisation in the case of the Turkish-Kurdish conflict between 1980 and 2000 , refers to them as transnational brokers. She shows that they can be political entrepreneurs (associations, individuals, political wings), who successfully connect diaspora populations (and their resources) in Europe to the Kurdish actors in Turkey, and make the Kurdish case visible to European policymakers. This observation still holds true, as diaspora members and organisations operate as mediators between the host society political actors and those in the sending society. For example, the YPJ commander Nessrin Abdullah visited Paris in January 2016, where she gave a presentation to an audience consisting of both Kurdish diaspora members as well as of non-Kurdish listeners. The event was organised by diaspora organisations.

Even though mobilisations are fuelled and shaped by 'transformative' events that can take place in both the homeland and host country contexts, their success is also based on the mobilising structures and practices. One example of those is the structures of existing associations that are able to use their networks to invite and organise events for political entrepreneurs to address 
the diaspora audiences. The visits by political actors from Rojava, including female combatants, was a particularly efficient means to reach the host society political actors, as exemplified by the visit of Kurdish political leaders at the Elysée. In this sense, the pre-existing networks and associative structures of both pro-PKK organisations and other Kurdish actors played a crucial role in the mobilisations in Paris.

\subsubsection{Frames}

The third aspect of social mobilisation, frames, according to Sökefeld (2006: 270), are ideas that transform certain conditions into an issue, that help to define the grievances and claims, and that legitimize and mobilise action.' In the diaspora context, this includes references to belonging to the diaspora community that shares a common identity, to 'homeland' and to specific events that are framed to affect the entire community (see Quinsaat 2013). This is similar to Adamson's (2013) understanding of strategic framing that is employed to mobilise a diaspora. In her study on Kurdish diaspora mobilisation between 1980 and 2000, she shows how, via a strategic framing of the conflict, transnational brokers were able to deploy a certain sense of nationalism and to awaken a 'Kurdish identity', which then gained a politicised meaning. The construction of 'Kurdishness' took place via cultural, and hitherto political, activities, and appealed particularly to secondand third-generation members in Germany, who felt a sense of belonging to neither the Turkish nor the German state.

The strategic framing of certain critical events that resonate with diaspora members, particularly in ways that make reference to a sense of collective belonging or the ones that are emotionally laden, can be particularly efficient means for mobilisation (Adamson 2013). This seemed to be the case with mobilisations that followed the assassinations in Paris and the siege of Kobane. There was a framing of the Kurdish combat against ISIS through the victimhood discourse (Khayati 2008) as the Kurdish nation was constructed as being a victim of barbarous acts by ISIS. This 
was a familiar diaspora discourse to build on, as also noted by Karagöz (2017: 85), who observed that the stigmatisation of immigrant communities, especially when associated with the PKK, 'facilitates the perpetuation of a victimhood discourse used as a mobilising strategy to strengthen the diasporic community links. This means that the transnational space of Kurdish diaspora communities shows particular dynamics in terms of exile, the historical background of Kurdish nationalism, and the sense of 'otherness' that continued to inform the framing of the Kurdish combat against ISIS. Indeed, references to both past and ongoing events were used to construct a collective narrative of the ongoing struggle and political aims, which were then used to frame mobilisations (see Macdonald 2012; Orjuela 2018).

Furthermore, the framing of the Kurdish combat was made in a way that it extended beyond diaspora politics and the 'Kurdish issue'. One interviewee tells of the Rojava experiment and its applicability beyond the borders of Syria, particularly to the leftist movement.

Because what happened in Rojava, it's not only for Kurds. It's also the combat of the left, we can say, especially of the left. So I remember when even Marine Le Pen gave a speech for Kurds ... But it's definitely a combat of the left, because the left sees how the system is back there and that it works.

Rojava's societal experiment, deemed to be in danger by the threat posed by ISIS, was framed as having political significance beyond its borders, both in Syria and internationally. For instance, concerning the Kurdish leaders' meeting with then President Hollande, Zuhat Kobani, the PYD foreign relations official, told in an interview with Al-Monitor ${ }^{94}$ that they had explained their vision for Syria. He further continued on the topic of their political aims:

Our goal is to democratize all of Syria. We want decentralized Syria. We have proven ourselves militarily and politically. We put together a democratic governance model incorporating all 
political, ethnic and religious groups. We want this system to prevail in all of Syria.

In the overall material, it was frequently emphasised that the combat led by Kurdish troops in Syria did not only concern them; the Kurds were fighting for a societal model that had universal value. Also, the fact that ISIS had organised attacks on French soil was an efficient means of framing the issue to also concern the French state and its citizens. Other similarities with France were drawn when framing the combat, with references to the familiar political vocabulary of leftist movements (resistance, solidarity). As one interviewee observed,

The resistance means a lot to the French people. They remembered this feeling of resistance with Kobane, when resistance came to mean protecting the values of your homeland. It means a lot to the French. In the Second World War, when the Germans came, there was a sentiment of resistance.

These frames were employed by transnational brokers who addressed the diaspora audience in France. For instance, women's role in the ongoing conflict ${ }^{95}$ as combatants was also underlined by the YPJ commander Nessrin Abdullah during her visit to Paris in January 2016, when she not only highlighted the international dimension of YPJ's struggle but emphasised that Kurdish women were engaging in two simultaneous battles. The first was the national struggle for the liberation of the Kurdish people, and the second a struggle for women's rights via raising awareness of the significance of emancipation and self-determination. ${ }^{96}$

Another aspect of this framing was the media representations. What made the media representations of the shared combat against ISIS even more powerful and persuasive was the emphasis put on Kurdish female combatants fighting the patriarchal ISIS. This framing stood in direct opposition to the discursive and legal framing of the PKK as a 'terrorist organisation'. The Western political powers, as well as the media, initially avoided associating the PKK with the YPG. Indeed, once referred to as 'terrorists' in 
the mainstream media, the representation of the PKK and YPG significantly changed in the course of the conflict. The Kurdish YPG and YPJ troops were soon depicted as the only forces capable of deterring the attacks by ISIS in the region, particularly after the massive breakdown of the Iraqi army and the flight of its soldiers, which left a sizeable arsenal of weaponry in the hands of the advancing ISIS forces. Both the media and diaspora actors' framing of the Kurdish combat against ISIS, which simultaneously drew from the victimhood discourse and portrayed the Kurdish combatants as defenders of universal, democratic values, stood in stark contrast to the 'terrorist' discourse associated with the PKK.

\subsection{Political Ambivalence: Terrorist or Not?}

We can say that the diasporic claims and projects were formulated in the context of political ambivalence. The background of this 'ambivalence', as it was communicated in the material, originated from the fact that the PKK was added to the list of terrorist organisations in the European Union in 2002. ${ }^{97}$ One of the main groups fighting ISIS in Kobane was the PKK, closely affiliated with the YPG/YPJ, an ally to international forces in the combat against ISIS. With the increased media visibility that Kurdish combatants received following Kobane, the question of the criminalisation of the pro-PKK movement in Europe and the listing of the PKK as a 'terrorist organisation' led to what the interviewees identified as political ambivalence concerning the 'Kurdish question' and what actually constituted 'terrorism'.

\subsubsection{Criminalisation}

How did this question of 'terrorism' play out in France, then? After the attacks on the French newspaper Charlie Hebdo in Paris in January 2015, the prime minister, Manuel Valls, declared that France was 'in war against terrorism. ${ }^{98}$ However, the security measures that were reinforced after his declaration had already been in place for decades, in particular the infamous Fiche $S$ 
(security file), applied to individuals considered to represent a potential threat to the 'security of the state. ${ }^{99}$ After the attack in November 2015, Valls confirmed that in total 20,000 individuals had Fiche $S,{ }^{100}$ of whom 10,500 people were suspected of having contact with Islamic movements and the others for their suspected belonging to movements considered terrorist, such as the PKK. ${ }^{101}$ As one second-generation interviewee, who had previously been politically active in the ranks of a pro-PKK organisation, said:

Fiche $S$ - it's for everyone who is more or less politically active, who could be an inconvenience to France. Unfortunately, the Kurdish movement in Europe is considered a terrorist organisation, so everyone who's more or less active in it has Fiche $S$... I have never been arrested in France, I have a clean record, but I have Fiche S; it's by the French secret service.

As far as pro-PKK activism in France was concerned, after 2006 the application of security measures was intensified (Marchand 2017: 154-156). A defence lawyer working on the cases of Kurdish political activists prosecuted in Paris noted that after 2008 such measures comprised at least 22 police operations initiated against Kurdish individuals and associations, as well as 256 arrests, including dozens of indictments and legal procedures. ${ }^{102}$ Another interviewee observed the following change in the authorities' attitudes towards pro-PKK activities after 2007.

Interviewee: There has been a certain criminalisation since 2007. The French politics towards the Kurdish movement changed drastically then.

MT: Why is that?

Interviewee: Well, there was some international agreement between Turkey and France. Till then, France knew about the activities and followed them, but then, I'm not sure which trade agreement they passed, but the approach changed radically. There was a wave of arrests in 2007,2008, another one in 2010 and one recently, and the court cases take years. They end in nothing, but it stays in the record even though the court case is cancelled. 
In 2006, 18 Turkish citizens were arrested for their suspected membership of the PKK. At the same time, the Kurdish Cultural Center, Ahmet Kaya, in the 10th arrondissement in Paris was accused similarly of association with and financing of a terrorist organisation (Le Monde ${ }^{103,104}$ ). In 2017, 13 people were arrested in the Parisian region for same allegations. ${ }^{105}$ One interviewee told of this wave of arrest in the following way: 'In 2007, there was a wave of arrests in France, of persons who worked for the Kurdish movement. So, we gathered some 50,000 Kurds to Paris to demonstrate.' These waves of arrests were referenced upon by some interviewees and sparked some mobilisation to contest the court decisions and rulings through demonstrations and petitions.

In 2011, France and Turkey signed a major agreement concerning internal security. It stated that the two countries engaged in 'operational collaboration in the combat against terrorism. The minister of the interior, Claude Guéant, expressed the total determination by France to fight with Turkey against the terrorism of the PKK. He also mentioned that, in 2010 and 2011, 38 and 32 members of the PKK had been arrested in France. ${ }^{106}$ In 2012, Adem Uzun, a board member of the Kurdish National Congress (Congrès national du Kurdistan) was arrested and charged with 'financing terrorism' (Boon-Kuo et al. 2015). Some time later, an investigation was opened concerning his involvement in arms trafficking, before those charges were dropped in 2014 following the decision by the Court of Appeal. His lawyer, Antoine Comte, declared in the French media that 'It was a disturbing decision in the sense that the French police abided to the political oppression practiced by the Turkish authorities. It all started with Turkish intelligence' (20 Minutes $2016^{107}$ ). In early 2015, 10 Kurds were accused of having financed the PKK and were condemned following the antiterrorism legislation. The Court of Appeal condemned Maison du peuple kurde in Marseille for collecting funds for a terrorist organisation (Le Monde 2015 ${ }^{108}$ ).

In fact, most cases seem to concern the 'participation and financing of a terrorist organisation', which is also visible in the rejection of citizenship applications and in the reluctance of 
authorities to renew visas for politically active Kurds on the premise that their 'loyalty towards our institutions and our country is not guaranteed'. One such case took place in 2015, when a Kurdish individual's citizenship application was denied on the basis of her husband participating in the 'financing of a terrorist organisation', in this case the PKK. ${ }^{109}$ The request to overturn the decision reads as follows:

Madame A B spouse X requests the overturning of the decision of 3 February 2015 by which the Interior Ministry rejected her request for citizenship on the grounds that the loyalty of her husband towards France and its institutions was not guaranteed. ${ }^{110}$

This echoes the French state's attitude towards migrants' political activities that are directed towards their homeland, which are 'often met with official suspicion' (Escafré-Dublet 2014: 5), as discussed in the previous chapter. The phrasing 'on the grounds that the loyalty towards France and its institutions is not guaranteed' also speaks volumes of the relationship between the citizen and the state in the French context. ${ }^{111}$ Indeed, it means the exclusion of the national community by means of losing one's citizenship, a debate that has been invoked in relation to terrorism in France since the 1990s but which has resurfaced with the question of ISIS fighters with acquired French nationality. Between 2002 and 2016, 13 French citizens lost their citizenship because of terrorismrelated sentences. ${ }^{112}$

The overall material also included references to the tense relations between the French authorities and the demonstrators in the past, which to some extent echo Baser's (2017) observations on the relationship between the German authorities and pro-PKK activists in the country in the 1990s. One interviewee told of her earliest memories in a demonstration where the police teargassed the demonstrators and beat them with batons: 'We were once in a demonstration and I don't know why, but the police attacked us with batons so we got scattered and everybody fled. I was maybe seven or eight.' However, one interviewee affiliated with a pro-PKK 
organisation described that there was a certain balance between the PKK and the French authorities, and with their political allies in the French leftist movement:

The PKK is very well settled in France. They have contacts with the socialist parties and the French secret service knows that they are here and that they organise always demonstrations ... And then there were the court cases for financing terrorism and several persons were investigated upon. The socialist party supports the Kurdish movement, but they are cautious about it at the same time. You don't want to create too much pression. There is a kind of a balance.

Indeed, it seems that the waves of arrests of individuals assumed of financing the PKK were fluctuating throughout the 2010s in France. One interviewee noted that such security measures were applied at the national level, including police operations targeting Kurdish associations in a way that coincided with diplomatic visits by Turkish politicians in France. These court cases were contested by associations and private individuals via petitions, political actions and appeals to authorities, including the case of Eutelsat concerning the suspension of two Kurdish channels in France following a request by the Turkish authority, RTÜK. As discussed in the earlier chapter, similar cases have taken place across Europe since the 1990s (Hassanpour 1998; Sinclair \& Smets 2014), including in Denmark ${ }^{113}$ (Schøtt 2021 forthcoming), the United Kingdom (Sentas 2015, 2018), Belgium ${ }^{114}$ and Germany. ${ }^{115}$ Indeed, the material collected for this study goes to testify of the continuing insistence of the Turkish state to pursue pro-PKK political action in a way that extends its sovereignty beyond its state boundaries into the European space, including in France.

\subsubsection{Contestations}

The political ambivalence in which the mobilisations took place were referenced by the participants, who considered the 
criminalisation of the PKK and the more general political approaches to the Kurdish struggle to be hypocritical and incoherent. The most common criticism concerned the criminalisation of the PKK while the YPG troops, ${ }^{116}$ close to the PKK, were fighting ISIS in Syria and Iraq, and being widely applauded for their actions. The interviewees referred to several contradicting cases. For instance, Kurdish female combatants' meeting with President Hollande at the Elysée received quite a lot of media attention. ${ }^{117}$ Simultaneously, members of the PKK were pursued in court in different European countries. One example given of this political ambivalence concerned combatants who left different European countries to join the Syrian Kurdish military troops (YPG) in Syria. As a number of individuals simultaneously left for combat in the ranks of ISIS, both groups tended to be treated as potential terrorist threats on their return. ${ }^{118}$ This created some issues for the combatants, who returned to their countries after having fought in Syria with the YPG. For instance, the first court case of such kind that was opened in the United Kingdom was against the father of a British man who volunteered with YPG troops in Syria. ${ }^{119}$ Also, Schøtt (2021 forthcoming: 145-189) discusses Kurdish activism in the judicial arena and court cases against fighters who left for Syria in her study on Kurdish mobilisations in Denmark. The issue also attracted some media attention in France, with 'native' combatants returning after having engaged in combat in the ranks of the YPG. ${ }^{120}$

The ambivalence concerning Kurdish political claims was criticised and directed both to Europe and to particular countries, as shown by these two interviewees:

They are massacring Kurds in Eastern Turkey and you close your eyes, youth mouths, otherwise you'll receive a million refugees and it'll destabilise Europe. So the question is, are we Kurds just carpet merchants? We are 40 million, and we are carpet merchants for you and the Europeans are silent when Kurds are massacred ... We are fighting ISIS without any help, so there's hypocrisy. It's the UK, France, Germany ... For me it's total hypocrisy, it has to be said. 
It's also politics, really dirty politics. How can they look into the eyes of people who actually fought against ISIS? Everybody agrees that ISIS is the enemy of humanity, and the only people fighting them are the Kurds. Are they being helped by the Europeans? No. They are all just hypocrites.

Whereas the first criticism concerned more generally the broader political situation and the international listing of the PKK as a terrorist organisation, another raised point related more specifically to the French context. France has been used as the perfect example of a nation-state that considers itself universalist and egalitarian (Kastoryano 2002). The respondents considered there to be an incoherence between the republican values of freedom of speech and political liberties, and the criminalisation of pro-PKK Kurdish activism in France:

It has been written down, liberty, equality and fraternity, but you cannot see it at all. There are mottos that do not work at all in France, that's a reality.

For Kurds, I don't know how many people have Fiche S, but I know that, for a country where we speak a lot about the freedom of expression, of thought and such things, it's problematic.

Another point of criticism that was particularly directed towards France was how the families of three assassinated activists had not been received by the president at the Elysée Palace, unlike in other similar cases. One interviewee was particularly outraged by this treatment, referring to the long-standing tradition in France to acknowledge injustice in similar cases by the presidential invitation of family members. He contrasted the treatment of three Kurdish women's families to how the Jewish community was acknowledged when 17 French Jews were killed in attacks in January 2015. Following the attacks, President Hollande, with Prime Minister Valls and Israeli Prime Minister Benjamin Netanyahu, visited a synagogue in Paris. ${ }^{121}$ 
So with Jews, the families were invited to Elysee and Hollande went to a synagogue. It's not against Jews, the criticism I'm making. They have a strong lobby, they can make political pressure. But does the president of the Republic determine his approach towards peoples according to political pressure? We don't have a strong lobby but that does not mean you cannot come and express your condolences. It's really the greatest shame for France. We don't ask them to liberate Kurds. We just ask to be treated as human beings, like they do with others.

The interviewee referred specifically to the power of a lobby that the Kurds lacked, according to him. His narration also echoes more collective calls for recognition, not specifically as a nation but as human beings. The lack of such recognition on behalf of the French state was considered to be the result of political ambivalence surrounding the Kurdish political claims.

In this chapter, I have approached 'diaspora' as a category of practice, following Brubaker's approach that was discussed in Chapter 2 (2005: 12). In other words, I have examined how diasporic claims were made, and projects articulated and loyalties evoked and mobilised, instead of focusing on the Kurdish diaspora as a homogeneous community acting in a uniform manner. Instead, this chapter has aimed to show how group formation takes place through multiple actions, and how it makes more sense analytically to examine particular circumstances where such diasporic claims and projects are made, instead of approaching them as a group property. This also follows Sökefeld's (2006) observation that diasporas need to be thought of as imagined transnational communities that come about through specific processes of mobilisation, instead of considering diasporas as clear-cut communities sharing ethnicity, language, ancestry and so forth (see Quinsaat 2019). These diasporic claims and projects were formulated in the context of political ambivalence towards the pro-PKK movement in France, and more generally at the European level. Through such claims and articulations, the Kurdish (diaspora) nation became constructed as an actor that appealed to its relational others, in this case the French government and European 
institutions, and one that opposed ISIS and Turkey. This observation is similar to that of Eccarius-Kelly (2017: 43), who notes that the 'European Kurdish diaspora presents itself as an interlocutor for broadly conceived Kurdish interests and strongly supports the efforts that enhance the level of legitimacy for Kurds at the international political level'. There was indeed an increased level of legitimacy that the Kurdish diaspora actors managed to achieve at the international political level, the solidity of which in future, however, remains to be seen. 


\section{The Second Generation}

\subsection{Introduction}

Kobane was a peak that united the diaspora youth. It was heroic, mythic and a strong symbol. We had won in any case. Either we became the martyrs or we won against ISIS, which then happened. It brought hope, especially after the bitter feeling after Sinjar. ${ }^{122}$ It was a moment of pride, of unity. Since the enemy was ISIS, the French also felt concerned by it. (Second-generation Kurd, 32)

This interviewee referred to the emotions the Kobane siege stirred among second-generation members, how Kurdish troops' victory over ISIS generated a sense of pride among his generation, the unifying effect it had and how even 'the French also felt concerned by it'. As discussed in the previous chapter, a series of events in the Kurdish regions in Turkey, Syria and Iraq sparked mobilisation in the Kurdish diaspora communities across Europe. They also gained considerable visibility in the international press, notably the military engagement by Kurdish female guerrillas against ISIS (Toivanen \& Baser 2016). At the same time, the simultaneous criminalisation of the PKK and the international alliances made with the YPG, closely associated with the PKK, to combat ISIS evoked sentiments of ambivalence and incoherence among diaspora members. It was also in this context that the second generation mobilised for Kobane. 
This chapter builds on a discussion on the diaspora mobilisation that took place in Paris in the 2010s, following a series of different events, including the siege of Kobane and the assassinations of three Kurdish activists in Paris. In this chapter, I will specifically focus on the second generation of Kurdish parentage, and how they discussed these two events. This chapter is divided into three sections. The first two focus on the mobilisation and transnational activities by second-generation members, and how those differed from their parents' generation, tackling the following questions: how did the mobilisation play out in the case of secondgeneration members? What came from this mobilisation in terms of their transnational activities and engagements, and how did it differ from that of their parents' generation? The last section tackles the visibility the Kobane siege and the Kurds' combat against ISIS received in the international media, and what significance Kobane had for the second generation in terms of their understanding of 'Kurdishness', also discussing the online dimension of constructing the 'homeland'. This chapter, more broadly, deals with the following question: why did the Kobane siege, in particular, spark an interest in the second generation, compared to other events that had taken place in their ancestral homeland during their adulthood years?

\subsection{Kobane Calling ${ }^{123}$}

I think that there is a certain interest towards the Kurdish movement among the youth, notably with the civil war in Syria. More and more are interested and, in the movement of young Kurds of PKK, some are very committed. I think that there is a growing consciousness and, starting from 2013, we really felt it with as young as 12-, 13-year-olds becoming interested too. I don't know if that interest will really become concrete in the long run, though.

The second-generation interviewee, active in a pro-PKK organisation, described his observations concerning the awoken interest towards the 'Kurdish movement' among the younger generation 
since the early 2010s. Whereas some members of the second generation had already engaged in political and civic activities towards Kurdistan before 2014, it is clear that a series of events in Turkey, Iraq and Syria, including particularly the Kobane siege, also generated mobilisation among those members who had previously been less active. This was also reflected in other European countries, including Germany and the United Kingdom (EccariusKelly 2017: 45-46), as well as Denmark (Schøtt 2021 forthcoming). The interviewee above also expressed his doubt over whether the mobilisation would lead to any sustainable and long-term engagement among the younger generation. Whereas future research can delve more into this, we can say that the mobilisation of the Kurdish diaspora communities in the 2010s led to secondgeneration members taking part in a variety of different transnational activities that will prove to be either sporadic or sustained over time.

\subsubsection{Translocal activities}

So, what activities did second-generation Kurds in Paris take part in? In concrete terms, such activities included participation in numerous demonstrations, in electoral activities (long-distance voting and election monitoring campaigns in Turkey) and in humanitarian convoys and collection of funds towards Syria. They also consisted of translating and blogging on the Kurdish issue, organising and participating in campaigns and seminars to raise awareness of the situation of Kurds in Syria and Turkey, and even in some cases short-term visits to the Kurdish regions. In terms of formal, more institutionalised means, second-generation members engaged transnationally via pre-existing associations as well as via new ones that saw daylight in the early 2010s and that particularly targeted the second generation. For instance, the UEKF (Union des Étudiants Kurdes de France, Union of Kurdish Students in France), which has existed since 2010, included mostly members from the second generation. It organised a 
wide range of different activities for its members, as described by one member:

MT: So is it mostly second-generation members who take part in the activities ...?

Interviewee: Exactly, we are active at Paris 8 University ... We meet up weekly. So every committee meets up in their university and us, as co-responsible for each university, we coordinate and then all meet together every second week to manage activities.

MT: Okay, and what sort of activities do you then organise?

Interviewee: Conferences, seminars, film showing and debates, cultural days, festivals, a bit of everything ...

MT: So is it for the purpose to gain visibility, to raise awareness?

Interviewee: It's specifically to give voice to the situation back there, to make the Kurdish question more known, to meet up with students that are interested in the region and also to create connections, and in the long term to maintain those connections and work together on the Kurdish question.

The interviewee referred to the variety of different activities, ranging from more political conferences and seminars to more cultural events, such as film showings and festivals. He also mentioned the organisation's motivations to foster long-term commitment and to provide a space for such among participants. He referred to the importance of maintaining connections among secondgeneration Kurds and towards Kurdistan. This also motivated the establishment in 2016 of a second-generation Kurdish association, Ambition kurde, which identifies itself as a non-political association. The association's founder opened the motivations to establish the association by emphasising the need both to foster networks among second-generation Kurds and to engage towards the Kurdish question. Associations that attracted secondgeneration Kurds were also founded in other countries at the time, including Youth for Kobane in the UK and other pro-Rojava solidarity groups. Also, Schøtt (2021 forthcoming) observes how 
young Kurds established several associations in Denmark, following the Kobane siege.

One major theme among mobilised second-generation Kurds was the sense of urgency to react to these critical events, the Kobane siege and the assassination of three Kurdish activists in Paris. For instance, when talking about the siege of Kobane, one interviewee noted the change in her commitment:

For me, Kobane didn't change my commitment, but it changed the urgency of the matter. I couldn't wait anymore, so I think that the commitment did not change, but it speeded things up. It was now or never.

This was particularly visible in the rapid organisation of humanitarian convoys to Rojava. Kobane, which had been almost completely destroyed by the siege, became the target of reconstruction projects in the aftermath. One interviewee described his participation in sending a humanitarian convoy to Rojava, although the uncertainty of the convoys reaching the intended final destination seemed to be one major concern. The second spoke of the significance of reconstruction. In the words of the interviewee below, the quick recovery and reconstruction were highly symbolic and a sign of resistance against the destruction that followed the siege.

We collected different things, cardboard boxes of clothes, with my mother and my brothers. We have too many things ... Our friends participated too. I gave up new shoes that I had never worn.

MT: They were sent to Kobane?

Interviewee: They were sent to Rojava. Now it starts to slow down, and it would be our job to reorganise a collect with the Rojava Bureau of Representation here, and you need logistics, a truck, storage space, volunteers. And it would really need to go to the refugee camp with Kurds, Yezidis, Syrian ... Not to those with ISIS. 
If the villages in Kurdistan remain destroyed, for me it's serious, since it means that ISIS or the Turkish government have won. They came to start a war and they destroyed everything and then left. So, for me it's crucial to reconstruct quickly, to make an international effort now, and to focus directing all donations there. And to show that we are not afraid, that you came to destroy and we reconstructed right after. It's symbolic.

In addition to activities that were channelled through more institutional means, via associations for instance, second-generation members took part in private initiatives of a semi-institutional nature, such as humanitarian convoys, reflecting activities undertaken by second-generation members across Europe. For instance, Schøtt (2021 forthcoming: 107, 229-230) identifies a group of young Kurds who mobilised at the individual level instead of through associations or collective initiatives. She observes that, while other groups engaged in collective action through supporting the pro-PKK movement or what she calls the 'Kurdistan movement' (for independence in Iraqi Kurdistan), this particular group 'engaged themselves in individual projects pertaining to research, journalism, teaching, human rights, fundraising, media and art, utilising their professional and educational skills'. She also notes that such humanitarian action forged new transgenerational connections between the first and second generations, through discussions on how to navigate emergency aid to the conflict areas. This distinction was to some extent visible also among the participants in this study.

Overall, the activities second-generation Kurds took part in were transnationally orientated but also quite locally bound, with the exception of mobilities. They were locally bound in a way that potentially differs from more traditional diaspora politics in which the first-generation members take part. This was visible in how second-generation members mobilised via student associations at different universities, leftist networks and NGOs and not always via 'diaspora' organisations. In this sense, we can say that second-generation members mostly engaged in a translocal activism: one that was locally bound in terms of organisation and 
targeted audiences (in awareness-raising campaigns, for instance) and simultaneously one that was linked to the political situation in the Kurdish territories (see Brickell \& Datta 2011).

The local dynamics also became visible when talking about the assassinations of three Kurdish activists that took place in Paris one year earlier. In fact, the assassinations, in a way, laid the ground for the mobilisations that the Kobane siege generated. As the first interviewee described, the sudden proximity of violence made these events more tangible, with 'homeland' dynamics becoming conflated with 'hostland' dynamics. The second interviewee also made a parallel with the attacks that had taken place in Paris the week preceding the interview. She referred to the November 2015 attacks, which had been organised by ISIS members in the Bataclan concert hall and a few other places, including restaurants, in Paris. The mobilising effect and the sudden proximity of violence were referenced by several interviewees, who considered that the diaspora members were not used to the threat of violence in the host society, compared to the conditions in Turkey.

In fact, the mobilisation was already taking place. Many students joined us after the assassination of our comrades. It really created a shock. They understood the importance of getting involved. Often their parents had to leave the country for political reasons, economic too, so they are conscious of the question. They are not all politicised, but they want to get involved, in whatever way, for the people.

It's like with the attack that took place last week. Nobody was expecting to get exploded or killed in the middle of Paris by jihadists. It's a bit the same thing. It caused psychological trouble to the Kurdish population during quite a while, but also to the people working within the Kurdish movement, because of not knowing the perpetrators and the fact that one of them had managed to infiltrate the movement and to gain a position within it.

The first interviewee's account portrays a level of diasporic consciousness among the second generation: 'they are conscious 
of the question' and fully aware of their parents' motivations to migrate. As I will discuss this in more detail in the following chapter, I suggest that the observed translocal activities included also a 'diasporic' component in the sense that they evoked and aimed at changing the situation in the ancestral 'homeland'.

\subsubsection{Mobilising resources}

The sudden urgency to react to these transformative events was made possible by the existence of transnational networks and organising structures that had previously enabled Kurdish diaspora members to take part in cultural production and political activism and to be informed of the events back in the 'homeland' (see Chapter 4). The transnational networks and organisational structures, which are the result of decades of active diaspora politics, have also enabled second-generation members to engage in activities towards Kurdistan. One example of such transnational activities was, for instance, the sending of a team of diaspora members to monitor the general elections that took place in Turkey in 2015, organised via the HDP offices in Brussels. The teams consisted also of secondgeneration members.

As I have argued elsewhere (Toivanen 2019), the transnational ties, practices and mobilities can represent a significant mobilisable resource for second-generation members to advance their educational or professional advantages and to potentially contribute to the development of Kurdistan. Kinship ties, for instance, can come to constitute a form of 'migrant capital' that has become available to second-generation members as a result of their having been raised in a transnational space. One example of when the transnational networks became useful was in the case of visits to the Kurdish region, although this concerned only a few of the respondents. One interviewee tells how she left for the Kurdish region in Turkey to complete an internship, which then led her to establish networks in her professional domain towards the region. She observed the following: 
For my friends, I think that lot of things take place on Facebook, associations, events, collaboration ... There are people who left for the region, in Germany too, and who did a bit the same thing than I did. So my friend left for Kobane, for instance; she already came back. So I think that Kobane speeded things up, and persons that were not previously engaged, I think they became more engaged.

In the case of the interviewee above, her kinship ties enabled the mobility, which then led to the establishment of professional contacts in the region through her internship period that were not based on kinship ties. Although only a few interviewees took part in such mobilities towards Kurdistan, with the particular aim of contributing towards its development, it nevertheless remains an important aspect to consider concerning the role of the second generation in diaspora contributions.

At the same time, the interviews also echoed Eccarius-Kelly's (2017) observation on how the mobilisation that followed Kobane was more directed towards European publics, in addition to diaspora actors pleading to national stakeholders. Indeed, she observes that, during the siege of Kobane, Kurdish activism in Europe engaged more with European publics, with Kurdish activists also reaching out to international academic and media circles: 'The rise of a Euro-Kurdish intelligentsia succeeded in elevating Kurdish claims for recognition and historical justice, and their discussions received public attention' (Eccarius-Kelly 2017: 44). One example of the rise of the Euro-Kurdish intelligentsia and the role that second-generation members played in it is the KurdishEuropean Society (KES), based in Brussels. KES aims to promote cooperation between different European institutions and institutions in the Kurdish region. It identifies its members as 'scientists, officials, university graduates with different backgrounds and students from all over Europe, ${ }^{324}$ and speaks directly to secondgeneration Kurds. I participated in a meeting with Ambition kurde and KES where common interests and forms of collaboration were discussed. On the other hand, there was also a clear consciousness of the utility of fostering links to local stakeholders 
in France, yet with a transnational focus towards Kurdistan. For instance, one interviewee pointed out that the networks and links they fostered in France were crucial to the reconstruction projects in Kobane:

Because the links we foster here are beneficial to better understand the society back there. The relations that we create here, they are as important, to facilitate activities, projects ... For instance, it's quite simple, but the construction of Kobane, it's about the money, and one needs to find it, so we can create relations with the municipalities, projects that aim to it.

This speaks of the networks in which second-generation members are embedded and how they utilise such networks. For instance, Eccarius-Kelly (2017: 48) also notes that the Kurdish associations benefited from a rising number of highly educated secondgeneration Kurds: 'Activists who had gained advanced levels of education and improved skills relied on innovative discursive spaces to reach audiences through cultural events, art and photo exhibits, satellite programming and later through social media campaigning as well. The increasing number of highly educated second-generation Kurds in political mobilisations and the related actions is also observed by Schøtt (2021 forthcoming: 229-230), who notes that second-generation Kurds in Denmark perceive being Kurdish to be an asset, since they speak several languages and understand the political dynamics both in the diaspora and in Kurdistan. She also notes that they align with a global cosmopolitan class of young, educated people who in times of crisis mobilise in support of fellow Kurds and 'become occasional members of the diaspora, however, they continue to act in their own way' (Schøtt 2021 forthcoming: 230).

The complex spatial dynamics, namely second-generation members organising more locally or at the European level, may well reflect the changing nature of the diaspora and the role subsequent generations play in mobilisations. It is therefore important to acknowledge that second-generation mobilisations can be quite heterogeneous: they can include both those members 
who are more engaged via institutional means and associations' networks and those acting individually and through personal networks. The latter can also more easily fall outside the scope of research, as their transnational engagements are less visible than those taking place through associations, for instance. Yet, both need to be accounted for if the role of the second generation in diaspora contributions is to be better understood. Similarly, to fully grasp the role the second generation can play in diaspora contributions, their translocal activities and engagements ought to be approached more broadly than merely evidencing some sort of kinship connection to their ancestral 'homeland'.

\subsection{Generational Particularities}

Studies on young people's political (dis)engagement have suggested that the contemporary youth is less and less interested in politics (Kitanova 2019). Three explanations have been given for this, as listed by Mahéo and colleagues (2012: 409). The first posits that younger generations have lost interest in politics and become more cynical towards it (Henn, Weinstein, \& Forrest 2005). Another line of research suggests that resources, such as their socio-economic position and knowledge of politics (Favre \& Offerlé 2002), affect the youth's participation in politics (Muxel 2002). The third line of research accounts for the changes that have taken place in contemporary societies, changes in entry to the labour market or the combination of work and studies that leaves little time for political engagements.

These studies approach generations as those belonging to particular age cohorts, in contrast to migration studies that deal with 'generation' often in terms of the first and second generations, referring to those who have migrated and to their descendants. This distinction is made with the argument that the lived experiences between migrant parents and their grown children are to some extent different in terms of having been socialised in different social settings (Levitt 2009). If we come back to the strategies suggested by Dahinden (2016: 2208-2209) in her plea 
to 'de-migranticize' migration studies, she suggested reorientating the focus away from 'migrant populations' towards 'overall populations. This raises this question: what else are we to see in secondgeneration young adults' approach to political (dis)engagement if we are to consider it in light of research conducted on youth's political (dis)engagement more broadly? In this section, I will discuss the generational dimension, by analysing both the sociological and 'migrant' generational aspects of how the research participants talked about politics and its generational particularities.

\subsubsection{Disinterest in (diaspora) politics}

The second-generation mobilisation and the activities that followed it were, in a sense, both quantitatively and qualitatively different from those of their parents' generation. The secondgeneration members considered that they participated less in political activities than their parents' generation did. One reason for this was the dislike towards more traditional forms of politics and disbelief that change could take place through such traditional politics. For instance, this interviewee communicated this dislike by equating the French political scene with that in Kurdistan:

In France, you have many people that are fed up with politics, there are many intellectuals who don't give a shit, because the politicians say one thing and then do another. And it's the same thing back there [in Kurdistan], between the promises and what is actually done. Let's take the example of my young brother. He says that it's not politics that will solve things; they won't solve the conflicts. In fact, if there were no politics, perhaps things would be simpler.

This echoes the findings concerning the perception of politics among the younger generation, regardless of their background. In this sense, we can say that the second-generation Kurds' experiences reflect the general tendencies of their age group as far as beliefs in the political system are concerned. For instance, the European Survey in 2005 showed that only $37 \%$ of 15 - to 25 -year-olds 
expressed an interest in politics (EUYOUPART 2005a), and that the younger generation is generally less interested in traditional party politics than older generations are (Bennett 2008; Furlong \& Cartmel 2007). The EUYOUPART (2005b) survey concerning the French data showed that the interviewed youth were less interested in politicians and political affairs concerning partisan quarrels, but in general felt concerned about national issues and international problems. This means that contemporary youth can well be turning towards alternative modes of political participation, including digitally networked action and everyday politics in the form of petitions, boycotts, demonstrations and so forth (Dalton 2017; Inglehart \& Welzel 2005; Sloam \& Henn 2019). In fact, maybe one reason that the young second-generation Kurds found the Rojava experiment particularly fascinating was this disenchantment and disinterest towards more traditional politics, including diaspora and non-diaspora politics.

Furthermore, there were also more diaspora context-specific reasons that were named for the dislike towards politics. These were the high level of hierarchy in diaspora associations and in 'homeland' politics, and the lack of critique and nuance in political debates. One interviewee opened this problematic in the following way, also evoking the role that the second generation has to play:

The freedom of thought, the freedom of expression, the freedom to say whatever you wish, for me it's very important. But back there, it's not seen that way. It's between the leaders, and if Mr Leader says something, everybody follows. It's not the French way, you can agree on something and disagree on something else. Back there, you agree on everything or on nothing; it's really binary. They don't have the culture or education for nuance, which is very important. I think that, today, the second generation tries to put in place and to transmit that towards the Kurdish issue.

He also observed the lack of critique in 'homeland' politics, compared to the French political culture, also mentioning that it takes time to build such politics based on debate. This echoes the socialisation into the French political culture (see Crul, 
Schneider \& Leslie 2010; Crul \& Vermeulen 2003); he also referred to the role that the second generation could play in this regard. Another diaspora-specific reason for the dislike towards politics was interethnic relations, which were often seen as conflict-based, especially among the first generation. One interviewee affiliated with a pro-PKK organisation felt that the younger generation was transcending the political (and ethnic) divisions within the movement, which were of more importance to their parents. Another pointed toward the role of the second generation to 'take matters into [their own] hands' so that the rivalries between the Turks and Kurds could be overcome.

I think that our generation has enough distance, and my hope is that people involved in the PKK ... the generation before, they are way too in it. But that our generation, I hope that there is no more that animosity between the parties and that youth born in France will be different and don't make the same mistakes as our parents that are a bit fascist.

It is really our task to take matters into hands; it's my generation's task to make it so that there is no rivalry between Turks and Kurds in some years' time. Unfortunately, if we don't succeed, it will be for the following generation. The first generation tried and failed, so it's now our turn to do things right.

These accounts echo Baser's (2015a) observations on the significance of interethnic relations and how those are communicated between the first and second generation. As she notes, the context of socialisation and politicisation in the hostland remains highly significant in terms of whether the interethnic conflicts pass and are 'inherited' from the first generation to their descendants. Her study dealt with first- and second-generation Kurds in Germany and Sweden, and showed significant differences between the two Kurdish communities concerning this. This study's findings seem to indicate a tendency similar to her observations (2015a: 268) that, unlike the first generation, the second generation '(re)constructs the conflict through the prism of their experiences 
in the host country'. Building on this observation, we can also conclude that the second generation reconstructs peace through their experiences.

\subsubsection{Redefining 'political'}

Indeed, one major difference that was communicated between the first- and second-generation activities concerned the political nature of activities. The second-generation members seemed to express a preference towards apolitical activities compared to politically and ideologically motivated activities. This was related not only to conflicting interethnic relations but also to political divisions within the Kurdish communities. One second-generation interviewee, active within the PKK, reflected the generational differences when he had discussed alternative ways of organising activities with the older generation members. In fact, he referred to the preference that the second-generation youth had to engage more locally and in a less hierarchical way. Another interviewee underlined that the movement had not been able to change to accommodate the needs and the visions of young Kurds in Europe. He specifically pointed out the division between Kurds in Turkey and other parts of Kurdistan, with the younger generation identifying themselves simply as Kurds.

The alternatives didn't please the elder. They are not like us. There are many young people, like myself, who have this mentality and who engage in a similar manner, in a better manner, in a way that the activism is more local, much less elitist.

Today most youth do not feel concerned by the PKK. Or not that they are not concerned by the PKK, all Kurds are for the PKK, no matter where they come from. But, today, people do not feel so much concerned by the PKK. The party has moved away from the vision of young Kurds in Europe. Because they are about the Kurds in Turkey, Kurds in Iraq and Kurds in Iran, and what the young people today want, in fact, is just to get along as Kurds. 
This preference for politically neutral associations and activities was communicated in relation to the need for unity and to an understanding of pan-Kurdish identity that transcended national boundaries, which I will discuss in more detail later. At the organisational level, this also gave birth to new associations that were explicitly apolitical in character, and which emphasised educational or cultural activities. One example of a politically independent association was the foundation of Ambition kurde, which focused on educational and cultural activities, particularly concerning the second generation of Kurdish parentage in Paris. At the same time, the association's activities included supporting the reconstruction of a school in Rojava. This was one example of the translocal activism that second-generation members took part in and that included political, cultural and educational aspects. Also, Schøtt (2021 forthcoming: 105) observes how young Kurds in Denmark established KAD, Kurdish Alternative in Denmark, to bridge the gap between young supporters of PKK and the Iraqi Kurdish movement, by dissociating themselves from political parties.

However, it would be rather simplistic to conclude that the second generation was politically less engaged than their parents owing to their dislike or disinterest in politics. Several scholars (Mahéo, Dejaeghere \& Stolle 2012; O’Toole 2003; O’Toole, Marsh \& Jones 2003) have argued that, to study contemporary youth and political engagement, it is necessary to acknowledge that the definition of politics has changed. Instead of focusing on formal politics or electoral activities, they suggest that non-electoral activities, including boycotting or signing a petition, also need to be accounted for (Mahéo, Dejaeghere \& Stolle 2012: 407). This means that such participation can also be spontaneous and sporadic in time, instead of a long-term commitment in formal politics.

In fact, when inquiring about the nature of activities, the interviews with second-generation members and other stakeholders confirmed that the members of the second generation also tended to participate in activities different from their parents. 
For instance, whereas the commemorative events and political meetings were mostly attended by first-generation members, the second-generation members instead took part in cultural events, concerts, associations for educative purposes and so forth, which they did not necessarily consider political activities. They also engaged in sporadic activities via different online spaces.

Indeed, another significant difference that was communicated by the interviewees concerning the transnational engagements between the first- and second-generation members was the use of social media tools. The online activities that the secondgeneration youth participated in included blogging, distributing information on Turkey, Kurdistan and the Middle East, circulating petitions, communicating their own views, engaging in online debates, and also in some cases using social media platforms to organise activities, events and seminars to raise awareness of the situation of Kurds. This they did in French, Turkish and Kurdish. At the same time, it meant that they were frequently and visually informed by the events taking place in Kurdistan. Indeed, the sensitisation to the conflict in Kurdish territories took place via the embeddedness in online spaces where images and videos of the Kurds' combat against ISIS were circulated. One interviewee described the influence of social media on the younger generation compared to their parents:

MT: How do you consider the significance of social media? Nowadays you see everything that takes place in direct ...

Interviewee: Yes, it is huge. As my parents are less on social media, they are less influenced by such media. They follow the newspapers or news transmissions on televisions, or they discuss the situation with others but they don't see what happens on Facebook, Instagram. That's true, there's a generational difference.

Studies on youth and political activism show that youths' repertoires of action reflect more global changes in political subjectivities, including technological changes that modern societies are going through (Mahéo, Dejaeghere \& Stolle 2012; O’Toole \& 
Gale 2010; O’Toole \& Gale 2013; Sloam \& Henn 2019). In other words, the ways younger generations engage in civic and political activism are rapidly changing, and this change naturally also touches upon young people of migrant parentage. For instance, several of the online activities were not considered 'political' by interviewees. In fact, the understanding of 'political' seemed to be associated with direct political action and in the frame of more traditional (diaspora) party politics that characterised their parents' generation. Instead, they rarely identified their 'offline' or online transnational engagements as purely political, although they did contain a political dimension in the sense that they addressed and aimed at a change in the situation in the Kurdish regions. Similarly to Costa and Alinejad's (2020: 4) observations, some second-generation Kurds engaged in 'homeland' politics by the management of online information, without actually taking part in political organisations and groups. This speaks volumes to both the changing nature of politics but also more generally to the changing understandings of it among the younger generation.

Overall, the second generation's political (dis)engagement differed in some respects from the activities in which the members of their parents' generation engaged. For instance, the informal activities were often spontaneous, such as participation in demonstrations, and potentially sporadic in nature. There was also more emphasis on cultural and educational, that is, non-political activities, which was communicated through the dislike towards the existing political divisions among Kurdish political actors and diaspora associations. Also, the respondents' accounts indicated a greater use of the online space and platforms, to distribute information and to get organised, than their parents' generation. At the same time, second-generation activities can be considered to include a diasporic component in the sense that they evoke the 'kinship' connection to an ancestral homeland, as will be discussed later. In other words, their modes of mobilisation and ways of engaging in diasporic circulation are reflective of having been raised in a transnational diaspora space but not limited to it. 


\subsection{Constructing 'Kurdistan’ Online}

MT: Since 2011, the combat has been widely mediatised ... Do you think that it contributed towards a mobilisation in the Kurdish diaspora and the youth?

Interviewee: In fact, it woke them up. It really showed that this can happen to us as well, people dying just like that. And since it's all over the Internet, on social media, it's where you see it the most. There were videos, images, and I think that it woke many youths, since there was a lot of discussion about Kurds and since we are Kurds. I know that, back then when my parents were young, it was way worse so that's why they were not that influenced by that.

This citation by a second-generation interviewee summarises quite poignantly the mobilisation for the second generation that followed the siege of Kobane. She referred to social media and its importance in making the combat more visible to second-generation Kurds, and how the Kurds were suddenly in the international spotlight. Indeed, the cruelties committed by ISIS in the Middle East were extensively mediatised by international news outlets in Europe and North America. ${ }^{125}$ As ISIS drew closer to Syrian Kurdish territories in the summer of 2014, the Kurds and the siege of Kobane were also thrown into the international spotlight. It can be said that Kobane was a turning point in the representations of Kurdish combatants and their role in the armed conflict in Syria. In fact, the international media framed the combat and the siege of Kobane by focusing largely on the role of Kurdish women fighters in the combat against ISIS (Buffon \& Allison 2016; Shahvisi 2018; Şimşek \& Jongerden 2018; Toivanen \& Baser 2016). The Kurdish 'guerrilla women' became such a phenomenon that even the clothing chain H\&M featured guerrilla overalls in their collection in 2014.

One example of media framing was the news story of the 'the angel of Kobane', Rehana, referred to as the 'poster girl' of YPJ. The news story was widely spread across social media sites, and was even picked up by mainstream media outlets, ${ }^{126}$ before the 
BBC published a news story setting the record straight. ${ }^{127}$ Rehana was constructed as the heroic incarnation of a female combatant. She allegedly took part in the battle against ISIS by killing a hundred of its combatants. Then she was supposedly beheaded by the organisation, before finally making an appearance in Kobane. Such representations of female fighters in 'Western' media, although quite one-sided, played a crucial role in giving visibility to the Kurdish combat. These news stories were also circulated by diaspora actors on different social media platforms, for instance via diasporic associations' Facebook pages, which strategically employed the visibility gained for political purposes (see Andén-Papadopoulos \& Pantti 2013).

As discussed in Chapter 4, the online space has been significant for the constructions of 'Kurdishness' and imaginaries evoking Kurdistan due to states' oppressive measures against Kurdish politics and culture (Hassanpour 1998). However, the media representations of the Kurdish combat against ISIS, particularly after the Kobane siege in late 2014, changed the way Kurdish political geography was reimagined and shaped (Kardaş \& Yesiltaş 2017: 265). Indeed, Kardaş and Yesiltaş (2017: 259-260) observe in their study on media representations on the Kurdish combat against ISIS the following:

The so-called Rojava revolution of Syrian Kurds and their struggle to break the siege of Kobane from the IS forces in particular have remarkably been at the centre of a meaning-making strategy around which verbal and visual representations of identity, war, gender and global politics coalesced.

The authors conclude that there are two outcomes of the internationalisation of the Kobane War: the regional consolidation of Kurdish identity and the international support for Syrian Kurds following the mobilisation of global support. Such pictography did not only generate global support but was also a mediated experience. In their study on second-generation Kurds in Italy, Costa and Alinejad (2020: 2) refer to such mediated experiences as 'a state of being, a set of perceptions, feelings, and emotions that 
are bound to media practices and doings'. For instance, one interviewee told how she experienced the war as a mediatised experience, bringing the conflict closer:

I feel that there is a lot of exaggeration online and suddenly we feel very concerned, perhaps more than what is necessary. There is a lot of manipulation in social media, so our parents are affected differently because they have a distance to them and they know about the situation already. They are more objective because we young people are influenced by the images of killed children, destroyed wells, videos of people being burnt, I'm really scared of ISIS because of that, so social media has a great impact.

In this section, I will discuss such narrations of mediatised experiences in the context of the positive visibility that the Kurdish combat received, which was far beyond the more traditional diaspora news outlets. The second-generation members were embedded in both mediascapes, diasporic and non-diasporic, and in many cases also had access to such spaces through mastering several languages (Kurdish, French, English, Arabic, Turkish). I will discuss firstly how second-generation members referred to the media's framing of the Kobane siege and more generally of the Kurdish combat against ISIS, and secondly how these media representations of 'Kurds' and of the Kurdish combat against ISIS were discussed in relation to their understandings of 'Kurdishness'. What meanings did the mediatisation of the combat, communicated largely via online spaces, evoke for secondgeneration members in terms their relationship to Kurdistan?

\subsubsection{Visibility}

In October 2014, Marie Claire published a news story titled 'These Remarkable Women Are Fighting ISIS. It's Time You Know Who They Are. ${ }^{128}$ One month later, The Economist published a news story titled 'The War against Islamic State. The Kurdish Stalingrad, ${ }^{29}$ thus making reference to the battle in Stalingrad between the Soviet Union and Nazi Germany in 1942-1943. ${ }^{130}$ 
Some interviewees also depicted the fight for Kobane as the 'Kurdish Stalingrad.' The Kobane siege and the Kurdish troops' combat against ISIS also received lot of media attention in the French press. For instance, Arte published a short video in July 2015 titled 'Kobane, Martyr City' ('Kobane, ville martyre'131), while several other news outlets reported on the siege in a detailed manner. Also, books dealing with the topic were published, including one by Patrice Franceschi, To Die for Kobane (Mourir pour Kobané). In it, he tells of his experiences of accompanying Syrian Kurdish forces over two years, shedding light on the political ideology of the Kurdish-led Syrian Democratic Forces, contrasting it to that of ISIS. During one interview, a young second-generation member took Franceschi's book out of his bag and told me that it had really made an impact on him.

These media productions on the Kurdish combat against ISIS were followed online and via social media platforms by secondgeneration members. The visibility the Kobane siege received resonated among them. Also, not only was news of the siege widely distributed in news stories; it also featured in photo exhibitions, movies and other cultural artefacts, as discussed earlier. In fact, the images of the Kobane siege and of the combat against ISIS were circulated in both 'offline' events and online spaces in which second-generation members were embedded. Also, the media visibility was not just any kind of visibility. What was emphasised by the interviewees was that it was positive media imaginaries that were circulated in social media. As one interviewee described the impact of this positive visibility,

Yes, because when we came to France, and we said we were Kurds, nobody knew what that meant. Today with the media visibility, it's true that people know who we are. And suddenly they associate it with the combat against ISIS, so for once we are on the right side, and not considered 'terrorists'.

As this interviewee described, the Kurdish military action was associated with the combat against ISIS, thus casting them in a positive light. The interviewees also noted the stark difference 
to the previous media visibility that the Kurdish military action, notably by the PKK, had received. Listed by the EU and the US as a terrorist organisation, the Kurdish question in Turkey has been framed through a 'terrorism discourse' for decades, although there has been an increasing visibility of the Kurdish issue in Turkishlanguage media (Yüksel-Pecen 2018).

Therefore, the media representations of the Kobane War did evoke the question of terrorism, but associating it this time with ISIS. Instead, the Kurdish military action was framed through the narratives of 'resistance' in the international mediasphere (Kardaş \& Yesiltaş 2017). This resistance was communicated through the juxtaposition between the Kurdish forces and ISIS, starkly contrasting their ideological foundations and the role of women in both movements. The interviewees also associated this positive visibility with the juxtaposition of the Kurdish forces with ISIS, with the former considered to defend democratic values in a region riddled with authoritarianism and dictatorships. As one interviewee observed,

In France, there is a positive opinion on Kurds because they defend the democratic values in a region where it's not evident to do so. I have the impression that Western states, and France especially, recognise themselves in the values defended by Kurds so the contrast is easy to make when it's about a region such as the Middle East where there are many dictatorships and authoritarianism.

Within this frame, the Kurds became soon depicted as the heroic defenders of human rights and liberal values, fighting off the barbarous ISIS terrorists (Kardaş \& Yesiltaş 2017: 263). For instance, the New York Times published an op-ed in March 2015 titled 'The Kurds' Heroic Stand Against ISIS. The article ended with a plea for the United States to 'help the Kurds translate their bravery into a true ability to defeat the Islamic State.' In fact, Kardaş and Yesiltaş (2017: 259) note that the media outcry that centred on the atrocities that ISIS committed towards Kurds and the Yezidis contributed to the mobilisation of global support for Kurds, and, in 
military terms, to the formation of the international coalition of 60 states to combat ISIS. One reason for this was that these visual and textual meaning-making strategies employed by the international media made the threat of ISIS and the 'distant' war in the Middle East suddenly closer, thus awakening international solidarity.

There was also a strategic dimension to this media visibility. Evidently, the Kurdish political actors also took advantage of the online forums and channels to increase visibility for their cause and the combat they were waging in Syria. The secular and liberal democratic values were often put forth, including respect for gender equality (evidenced by the inclusion of women in military forces), respect for religious and ethnic diversity and emphasis on ecological values (Toivanen \& Baser 2016). The media representations emphasised the role of Kurdish women in the military troops, which also enabled the juxtaposition with the cruelty and patriarchy displayed by ISIS. The Kurdish actors aimed to take full advantage of this mediatised visibility to enhance their political aspirations, including during the visit of three Syrian Kurdish political leaders to the Elysée Palace in early 2015. Also, one politically affiliated interviewee discussed how the visibility that the Kurdish combat against ISIS received was employed strategically by the pro-PKK movement:

Like [name redacted] said the last time, the young people are very politized, so I don't think in itself it is something new. Everybody follows what takes place there, but it has taken more magnitude compared to before. Now the combat is more internationalised. Before nobody talked about it. Today, when you talk about Kurds in France, people know who they are. Ten years ago, when I was smaller, it wasn't clear at all. So that changed. I think that the major Kurdish conflict touched us all, it became mediatised. People want to know what takes place in Syria and we will take advantage of that for our cause.

On the other hand, whereas the visibility was overall perceived in a positive light, the media frames used to depict Kurds also drew criticism from some interviewees. The emphasis on Kurds 
being warriors and representing them through the frame of war and conflict was criticised since it was felt to overlook the aspects of Kurdish culture, literature and 'Kurdish civilisation', as one interviewee put it. Another criticised the superficiality of the media visibility, suggesting that they did not actually lead to any real political solutions in the region. Thirdly, most interviewees criticised the ambivalence surrounding the criminalisation of the PKK and the simultaneous positive visibility that the Syrian Kurds received. This, it was suggested, showed the hypocrisy of Western states towards the Kurdish issue and their compliance with the Turkish state. The silence of the EU towards the military measures by the Turkish state in the Kurdish regions was strongly denounced, as was also their mutual agreement on Syrian refugees.

Overall, we can say that the mediatised visibility of the Kurdish combat against ISIS evoked many emotions among secondgeneration members, both appreciative of the positive visibility the Kurdish military combat received and sceptical of its actual ramifications. This mediatised visibility was also discussed in relation to 'Kurdishness', with narrations evoking a construction of a Kurdish nation.

\subsubsection{Kurdish (online) nation}

Yes, it's something we have never had before. We have experienced conflicts, massacres, but it was never so mediatised. This is really the first time, the whole planet was talking about us. I was joking with my brother saying that before we did not exist, and now all of a sudden we can say that being a Kurd is a pride, whereas before people didn't even know who we were.

In her study on Kurdish diaspora communities, Mahmod (2016:3) writes about the role of digital media for the constructions of imagined communities. She argues that 'new information and communication technology is increasingly challenging the imaginings of belongingness based on ethnicity, identity, and the nation-state 
that have been constructed largely through traditional media such as television, radio, and newspapers'. In other words, she suggests paying attention to how the Internet is challenging the notion of national consciousness. This is a particularly interesting question vis-à-vis the Kurdish combat against ISIS.

Online spaces were of great importance for the second generation and the Kurds' mediatised combat against ISIS was discussed in relation to understandings of 'Kurdishness', thus evoking constructions of the Kurdish nation. The positive media visibility evoked emotions, such as a sense of pride to be 'Kurdish', as articulated by the interviewee above. More importantly, the sudden media visibility was contrasted with the longlasting historical silence and ignorance concerning the Kurds and Kurdistan. In fact, the reference to Kurds' inexistence ('before we did not exist') echoed the historical denial of Kurdish identities and culture, which was now contrasted with the positive associations of being a 'Kurd'. Several interviewees referred to the contrast between now and before, associating it with the assimilationist and oppressive measures that the Kurdish populations in the Middle East and Turkey had been subjected to for a number of decades (see Chapter 3). In this sense, the positive media visibility for 'Kurds' was interpreted as an acknowledgement of their existence and based on some form of exilic memory, as discussed later.

The invisibility and ignorance concerning the Kurds was not merely a historical fact; it was in many cases a lived experience. One interviewee recounted how her teacher had reacted after having heard of her identifying herself as 'Kurdish'. Several others shared similar experiences when they had been taken for a 'Turk'. This, however, was gradually changing with the media visibility that the Kurdish combat against ISIS had received in 2014.

I was in the bus with my friends from the French high school and we spoke in French. One lady asked me, what are you? And I told her, well, I'm Kurdish. Then she told me that I wasn't Kurdish, that I was Turkish. I replied that no, I'm Kurdish, and she told me that there are no Kurds. I was really shocked because she was 
a professor, somebody educated. How could she say something like that? I was hurt and sad.

Before it was like, where do you come from? I'm a Kurd. Oh, you are Turkish. Nope. Isn't it the same thing? No, it is not. The difference started to emerge with the arrival of ISIS in the Middle East and when Kurds started to rise to the international scene.

These instances show how second-generation youth were positioned by their surroundings, therefore touching upon the question what it means to be 'Kurdish'. The discussions on media visibility and how that related to 'Kurdishness' brought up also how they wished 'Kurdishness' to be understood, transcending regional and political divisions. The need for unity and to identify oneself merely as a Kurd, and not as a Kurd from Turkey, Syria, Iraq or Iran, was also discussed at length. One interviewee explained how she became engaged for the first time in her life, since she felt that it was important to do something that would unite the Kurds.

Usually I don't like organisations like that since the Kurdish organisations in France are anchored in politics, whether it's the PKK or I don't know what. The thing I don't like at all is that, before thinking about politics, we need to think about our unity. Before being on the left or the right side, we are first and foremost Kurds. So I think that it's important to find something that unites us, even if today we don't have a country. I think that the problems come from that, from the fact that the Kurds don't get along between each other ... It's the idea of being attached to an idea, to a flag, our origins, our culture, our language before being attached to a political idea. That's the most important thing for me and that's why I haven't been in any association before this one.

This also echoes Kardaş and Yesiltaş's (2017) observation on how the Kobane War increasingly regionalised and internationalised the Kurdish geopolitical imagination beyond the territorial and political complexities in the region. In such pictography as described by the respondents, the Kurdish nation became 
constructed in particular manner. Indeed, the narrative reconstructions and pictorial representations of Kurdistan employed by the international media suggested that the 'Kurdish homeland' was being in peril in the face of ISIS. The defence of Kobane was also represented as the defence of the 'greater Kurdistan' and the feared loss as the defeat for the entire Kurdish nation (Kardaş \& Yesiltaş 2017: 265). As Kardaş and Yesiltaş (2017: 266) note, 'the process of re-writing of the Kurdish geopolitical space during the Kobane defence further strengthened and consolidated the feeling of Kurdishness despite the territorial and demographic complexities of Turkey's, Syrian and Iraqi Kurds'. This rewriting of the Kurdish geopolitical space, as referred to by the authors above, was visible also in second-generation members' narrations concerning Rojava.

Indeed, what was noteworthy was how these ideas of 'Kurdistan' were projected towards Rojava, although the large majority of interviewees did not have any kinship connection to Syrian Kurdistan. Rojava was imagined as a kind of a societal laboratory, towards which political aspirations could be more easily projected. Furthermore, such aspirations were articulated on an ideological basis, not so much as Rojava representing a societal experiment for Kurds and only Kurds. For instance, one interviewee described this in the following way:

It's like a laboratory, Rojava. It's a laboratory of Öcalan, where his ideas are being applied. Rojava fascinates us and why we could die for Rojava is because of the values that they put forth. The assembly of peoples, equality between sexes, for instance, in councils, the respect of other peoples. In Kurdistan, there are also Arabs, Syrians, Turkmens and for us it's important to create a real atmosphere of peace between people. The main idea is not to have millions of Kurds, but Kurds who are conscious of their identity and of the society we could create that would place the human in the centre. The ideas of Rojava could be entirely applicable in other parts of the world too, because it is a system that accounts for the human in the first place, how to live together.

Rojava represented a concrete, physical place towards which the political aspirations and ideals could be more easily directed. It 
was represented in a way that it allowed ethnic divisions to be transcended and an idea of a pan-Kurdish identity to be constructed. On the other hand, it operated as way to express more general political discontent towards the existing political systems, as discussed later. This is similar to Costa and Alinejad's observations (2020: 5) concerning second-generation Kurds in Italy. The authors suggest that second-generation members use online communication to construct their own attachment 'toward the Kurdish cause and a Kurdish-imagined homeland'. They also note that the experiencing of this 'homeland' then takes place through regular, everyday practices of online political engagement (albeit not defined as political) that shapes their experiences of the homeland.

Costa and Alinejad (2020: 2) note that, for the first-generation migrants, social media reminds them of their exile, thus shaping their experience of homeland as a loss, whereas for the second generation social media contributes to 'shaping expressions of their political and ethnic consciousness and their becoming engaged in homeland politics'. Also, Müller-Funk (2020) observes concerning Egyptian diaspora youth in Vienna that the revolution of 2011 in Egypt led to a renegotiation of their relationship with Egypt, and that their activism was a way to claim their right to multiple identity constructions.

I argue that the second-generation members also (re)constructed their relationship to Kurdistan through the mobilisation and the diasporic activities they engaged in, including through their daily online practices. In this sense, the relationship to 'Kurdistan' was made by the second-generation Kurds through their translocal participation and in online spaces. This is similar to Alinejad's (2017) observations in her study on Iranian Americans that social media is used transnationally by second-generation members to mobilise homeland solidarities through symbols and discourses. In that sense, participating online, for instance via circulating posts and petitions to raise awareness, allowed secondgeneration Kurds to construct a relationship towards Kurdistan through immediate and spontaneous (online) action. 



\author{
CHAPTER 7
}

\title{
Diaspora and Beyond
}

\subsection{Introduction}

In Chapter 5 I discussed the Kurdish diaspora community's mobilisation and transnational participation that followed the Kobane siege, whereas in Chapter 6 I focused particularly on the second generation. This generation has evidently grown up in the transnational social reality, which is also reflected in their lived experiences. Also, the fact of having a family background in major diasporic movements from the region of Kurdistan towards Europe is visible in their narrations concerning mobilisation for Kobane and their transnational participation towards the Kurdish regions. However, it would be rather simplistic to conclude that the second-generation members mobilised for Kobane because of their 'ethnic' background or to treat it as a sign of lingering loyalties towards their ancestral 'homeland'. It would also be intellectually lazy (not to mention incorrect) to explain it away as a 'lack of integration' into French society. On the other hand, if we were to conclude that the mobilisation was only the result of second-generation members being embedded in a transnational space, we would miss other dynamics at play.

Indeed, I suggest that, if we are to fully understand the mobilisation and transnational participation of diaspora communities towards the 'homeland' (and their role in diaspora contributions) including particularly that of subsequent generations, a conceptual 
approach that moves beyond transnationalism and the methodological nationalism-coloured approach is needed. In this chapter, I argue that, if we were to focus only on the 'ethnic' or 'diaspora/ transnational' context in second-generation members' lived experiences, we would miss a great deal about other dynamics that also need to be included in the analysis. These include, for instance, the global transformations in political subjectivities and the broader tendencies in this generation's - that is, age cohort's ways and modes of political (dis)engagement. At the same time, if we were to understand how mobilisations take place through diasporic claims, stances, projects and practices, we need to move beyond treating diaspora-related mobilisations uniquely as something taking place between the host society and the 'homeland' and open our eyes to how diasporic claims, stances, projects and practices are also shaped by local and global forces.

This chapter deals first with the significance of the transnational diaspora space, before moving to discuss other lines of analysis, including 'generation' and the local/global context, that are not reducible to 'groupist' explanations (Brubaker 2002). This chapter specifically tackles the following questions: to what extent can we understand these mobilisations for Kobane through the focus on the transnational diaspora space and to be inscribed in the diasporic background of the second generation? What indeed is diasporic in their mobilisation and what is not? How can we understand the mobilised action and transnational participation among second-generation members without essentialising them simply as a manifestation of their nationalist feelings towards the ancestral 'homeland' - or as a lack of integration into the so-called host society?

\subsection{Growing Up Transnational}

Peggy Levitt (2009: 1266) argues that the second-generation is raised in a transnational field, meaning that the lines between the 'host country' and the 'homeland' become blurred, 'making them one interconnected social experience. This significance of the 
transnational field (or space ${ }^{132}$ ) cannot be denied, nor should it be. Indeed, one common factor for the interviewees was definitely the fact of being raised in a transnational social reality, following similar findings in case studies on second-generation Kurds in Finland (Toivanen 2014), Sweden (Eliassi 2010), Germany (Baser 2015a), the United Kingdom (Ata 2017), Italy (Costa \& Alinejad 2020) and so forth. For instance, the interviewees had often grown up visiting family members left behind, in multilingual environments speaking Turkish, Kurdish and French, and with daily references to the situation in Kurdistan and to the 'homeland' through (diaspora) media consumption. Several had also participated in the activities organised by diaspora organisations from a young age, albeit differently from their parents, as discussed in the last chapter.

One major debate concerning transnationalism has been whether the second generation is as 'transnational', and continue to engage transnationally with the same intensity and frequency as their parents' generation (Kasinitz et al. 2002; Lee 2008; Levitt 2009). Second-generation Kurds who participated in this study reflected upon their lived experiences, which were perceived to differ from those of their parents' generation. ${ }^{133}$ They were considered to participate less in transnational diaspora politics, as discussed in the previous chapter, although their definition of 'political' most often referred to traditional forms of (diaspora) political activism. However, there was ample evidence and references pointing towards having grown up in a transnational social reality. This is how one interviewee described her and her generation's experiences of having grown up in two differing social settings:

In fact, we are permanently between the two [settings], but for me it is totally normal. Because you have grown up in both, you went to school in France, in a multicultural environment, you come back home and it's $100 \%$ Kurdish. And at the same time, the two tend to get mixed too. When I got home, I taught my father French and my mother knows, for instance, all the French singers now because she saw us following them. Both learn from each 
other. So, thanks to us, we brought some international culture back home and our parents made a home where the Kurdishness is preserved.

Although her account shows that the distinction between the two social spaces at home and outside home environment is far from being clear cut, they entail different expectations and norms. For instance, she continued to describe the tensions that arise when these two social milieus' normative systems concerning gendered expectations compete:

So I have grown up in this double culture, but today I struggle. I'm torn between the two, between the communitarian rules and personal reasons. For my parents, it's a must that I marry a Kurdish person. But I don't want to be a housewife; I want to study and to work. Sometimes I wonder why we came to France, and life could have been simpler back home, in the village. The fact of leaving Turkey forced us to change and it's not always easy.

This is quite telling of the differing expectations and normative systems that the second generation can encounter. Anthias (2012: 104) describes this asymmetry in gender relations concerning the second generation and their embeddedness in the transnational social field:

for those who are embedded within two social milieus with different and at times competing normative systems, there are two sets of social relations, such as arrangements and expectations (say around gender, sexuality and behavioural norms ...) that impact upon their lives.

This has also been shown in other studies concerning secondgeneration members (Berrington 2020; Levitt 2009). What was particularly interesting in the case of two female interviewees was how they narrated their political participation in the PKK in relation to such gendered expectations. One interviewee explained how she escaped arranged marriage by joining a pro-PKK 
organisation during her teenage years, and of the significance the political engagement had in her case:

The PKK helped me to make it, it gave me an identity in that society. Because when you are a militant of the PKK, people respect you and even today, when I have left the movement, it follows me for the rest of my life. For me the Kurdish cause allowed to stand up to a patriarchal society and culture in which it is very hard to live. It helped me to get respect for who I am.

Also, Marchand (2017: 29) mentions in her book on the assassinations in Paris that one of the killed activists had opted for a political career in the PKK instead of agreeing to an arranged marriage suggested by her parents. Such accounts suggest that there is a need to understand the processes of politicisation for individuals in relation to normative gender relations (see Grojean 2019). Whereas the interviewees' experiences differed in terms of the gendered norms and expectations, the class position was also reflected upon. Having just completed a master's degree, one interviewee told of the significance of having an education that he considered to have 'inherited' from his parents. His father had been a teacher in Turkey prior to his migration, which is why he valued education highly. There had been a minimum requirement when he was growing up that the children in the family would acquire at least a high school degree, since everybody else in the family had completed studies. He discussed at length the significance of parents passing on to their children the motivation to study, observing that, in families where the parents had little education, this rarely took place. However, he considered that it was not sufficient to have such support from home to be able to make it in the labour market. For instance, he recognised the significance of networks to find an internship in his field.

The internships in the enterprises, it's very important in my field. And we who have very few networks, we know few people, it's really complicated. It's hopeless, in fact. In France, if you don't 
have networks, your mother or father knowing somebody, a friend, it's really hard.

The second-generation members did not necessarily possess such local forms of capital compared to their fellow students and colleagues of French parentage, although they did possess social resources that were available to them as a result of having been raised in the transnational field. As I have argued elsewhere (Toivanen 2019), these transnational networks and ties constituted a form of 'migrant capital' for them, as they held the power the be mobilised and converted to accumulate professional and educational advantages via the transnational field. Also, the transnational realities were evidenced by eventual plans or aspirations of 'return' to the ancestral 'homeland'. A few had returned temporarily for professional reasons (internships) or student exchange programmes (Toivanen 2019), and permanent 'return' was mostly not perceived as a viable option considering the worsening security situation in the Kurdish regions in Turkey.

I have discussed in this section, albeit very briefly, the transnational social reality in which the second-generation Kurds had grown up. At the same time, I have wished to point out that the second-generation's experiences and processes of politicisation are not homogeneous but instead they are shaped, for instance, by social differences of gender and class (Anthias 2012: 104). On the other hand, they were also shaped by the locality they had grown up in. For instance, some interviewees' families had lived in neighbourhoods and in cities that did not have major Kurdish communities and had therefore barely socialised with other Kurdish families when growing up. Therefore, instead of employing (migrant) 'generation' as a unitary category, we need to acknowledge that there exists a great heterogeneity within the second generation in terms of their lived experiences. Simultaneously, there were also significant commonalities that the diaspora and transnational lenses can help to unravel. As discussed next, in addition to the transnational social field, the second-generation members had also grown up in the Kurdish diaspora space. 


\subsubsection{Socialisation into the Kurdish question}

Besides the organisational dimension shaping broader waves of diaspora mobilisation, the transnational field is significant in terms of socialisation into the Kurdish question, particularly concerning the second generation. Levitt (2009: 1266) notes on the second generation that 'they are not only socialised into the rules and institutions of the countries where they live, but also into those of the countries from whence their families come'. Similarly, we can say that the second generation is also socialised into the political questions touching upon the ancestral 'homeland' through being embedded in the transnational diaspora space. The prior socialisation into the Kurdish question played a role in the second generation being familiar with the geopolitics concerning the situation of Kurds and Kurdistan in the Middle East. For some, this socialisation into Kurdish geopolitics and the related political activism meant that they had become engaged in diaspora associations at a quite young age. For instance, one second-generation interviewee had engaged in the Kurdish movement since his early teen years after having been socialised into the Kurdish question as a child.

In addition to the second generation's transnational political participation differing from that of their parents, there was also heterogeneity among the second-generation members in terms of their activism. For instance, some had already been active in the Kurdish movements before Kobane. They had taken part in different associations and organisations, had regularly attended demonstrations and political meetings, and had engaged in a variety of different transnational activities. The socialisation into political activism among some participants was therefore quite striking, although not surprising. One interviewee described it this way:

MT: So are there many people from the diaspora who come here from elsewhere for the meetings?

Interviewee: Yes, there are, but not that many. I have met several who come from Germany, England or elsewhere. They come 
because there's the atmosphere, everybody is together and motivated. It's impressive. Every party for us is a place of socialisation, for example every demonstration too. There are families that meet in every demonstration. And when there are demonstrations like in Strasbourg, they say that it's the opportunity to meet, to exchange, talk etc. So, they are places of socialisation where we plan to meet.

As Karagöz (2017: 96) discusses in her study, diaspora politics operate as a socialisation factor. She mentions that the second-generation Kurds have lived their first activist socialisation within the Kurdish associations, also pointing out that the second socialisation happens in the local activist spheres (with French NGOs and such). For instance, the interviewee above referred to the major demonstration that is organised yearly in Strasbourg to call for the liberation of Abdullah Öcalan. Demonstrations also taking place more locally in Paris operated as places of socialisation. As the interviewee described, this tradition to demonstrate has been passed on, in this case, from the mother to the daughter:

Interviewee: Before we were invisible, even with the demonstrations every Sunday. In fact, my mother told me that she participated in a demonstration when I was one year old, still in the stroller, and 20 years later we went to a demonstration together, one Sunday, and towards the end of the demonstration, she was tearing up and told me that she had attended the same demonstration some 20 years earlier and still they were making the same claims, that nothing had changed. So that was a bit sad, but now it has changed a bit ...

MT: So you and your family have the habit of going to demonstrations?

Interviewee: Yes, it's a tradition among the Kurds, to go and participate in a demonstration on Sundays.

MT: And it seems that it continues to be so ... I heard that the Kurds are one of the most politically active diasporas in Europe, with at least one demonstration a week. 
Interviewee: Yes, it is almost a need to go and shout, it cannot stay somatic ...

The interviewee above mentioned her mother's comment about how the Kurdish demonstrators had been making the same claims for the previous 20 years. The transnational space was significant in terms of socialisation into claims-making and the collective narratives such claims evoked. Regardless of whether or not the interviewees had already been politically active before the siege of Kobane, it can be said that all respondents had been more or less socialised to know the politics and the related discourses for claims-making that surrounded the Kurdish question. This was visible in references to the Kurdish question being politicised and to the politicisation of diaspora Kurds in general. As one interviewee noted, 'you cannot grasp your reality' without acknowledging the Kurdish history:

The politicisation ... We would have wanted to be artists or something else, but today the existence of the Kurdish people, dispersed across the world, the fifth part being the diaspora, you must be politicised first. If you do not know your history that is purely political, the fact of being divided into four parts since the 16th century, the reason and the consequences of that division, you cannot grasp your reality.

This resonates with the historical background of Kurdish nation as stateless and divided (see Chapter 3 ) and shows that, in addition to taking into consideration the transnational social field in which second-generation members had grown up, the diaspora space also plays a significant role in shaping their social realities. In this case, the exilic past, the state of statelessness and the ethnonational dimension of the Kurdish diaspora are also significant factors to consider when examining the second-generation Kurds' socialisation in the transnational space. That is to say that not only had they grown up in a transnational space with frequent references to the 'homeland'; they had also grown up in a transnational diaspora space that included frequent references to the division 
and the ongoing state of statelessness of Kurdistan, and to collective narratives of Kurdishness and the 'homeland'. In other words, their narrations pointed towards a transgenerational transmission of exilic memory and identity, as discussed in the next section.

\subsubsection{We are all Kurds, right?}

The Kobane siege mobilised a larger segment of the second generation than previous events taking place in the Kurdish regions had succeeded in doing (Eccarius-Kelly 2017; Schøtt 2021 forthcoming). Second-generation members took largely part in demonstrations and a variety of different transnational activities following the Kobane siege, as described in the previous chapter. Several interviewees had to some extent already been politically active or at least following the situation in Kurdistan even before the Kobane War, before becoming mobilised. However, the participation for most interviewees changed with the Kobane War. Why exactly did the Kobane siege mobilise second-generation members? How were the transnational mobilisations and engagements discussed in relation to constructions of 'Kurdishness' and the 'homeland'?

One reason for this mobilisation following the Kobane War was the media visibility that the Kobane siege received, not only in diaspora-led news outlets and Kurdish-language media but also in this case in the French media. The combat was particularly visible in the online spaces, as discussed in the previous chapter. This interviewee linked the increased visibility to the greater sense of revolt second-generation members expressed concerning Kobane:

I feel that Kobane affected me a lot, it was so much information every day, but I couldn't help to follow what was taking place. Sometimes I even felt like leaving everything here and going there, because I was so fed up with seeing all that news. I know that it's dangerous. It does nourish our revolt.

The significance of being embedded in online spaces and the impact of information flows that the second-generation 
Kurds suddenly experienced concerning the Kurdish territories is undeniable. The war between Kurdish troops and ISIS in Kobane represented a critical event triggering such mobilisation. This resonates with Hess and Korf's study (2014: 431) concerning the second-generation Tamils in Switzerland and their political mobilisation following the final battle in the civil war in Sri Lanka, in 2009. The authors argue that 'critical events' can trigger a politics of affect among second-generation members. They observe that:

For second-generation Tamils, the affect of witnessing the suffering of Tamils in the last days of the war in Sri Lanka generated a sort of 'home-coming' into the diasporic and transnational community of 'Tamilness' - in fact it intensified their 'Tamilness'.

In that sense, the authors relate the mobilisation processes to second-generation members' construction of their identity as 'Tamil'. There exists scholarship discussing the relationship between the second generation's mobilisation and their (often ethnic) identity construction. For instance, Weinzimmer (2008) has studied how the Israeli-Palestinian conflict affects the identity formation of first- and second-generation Jewish Israeli American and Palestinian Americans, showing that it is not only the experience of conflict but also its perception that bears an impact on the construction and maintenance of identity. Also, Müller-Funk (2020: 1112) shows in her study on Egyptian diaspora youth in Vienna that the revolution in 2011 led to a renegotiation of her interviewees' relationship to Egypt and that their activism was a way to 'claim their right to multiple identity constructions', including with both Egypt and Austria.

In many ways, the Kobane siege and the combat of Kurds against ISIS was narrated in relation to constructions of 'Kurdishness. In fact, what was often emphasised when talking about the Kobane siege and its significance for Kurds was the need for unity among Kurds. This is similar to Eccarius-Kelly's (2017: 41) observations that Kurds showed unprecedented levels of unity 
in continental Europe and the UK: 'In the struggle for Kurdish cultural identity, human rights and self-determination, few comparable moments exist that produced such levels of panKurdish unity as the desire to liberate Kobane from the control of ISIS.' In fact, one respondent even stated that they were the 'babies of Kobane', implying an experience that touched his generation beyond any political divisions that their parents might have fostered.

\section{Diasporic consciousness}

Often our parents had to leave the homeland for political problems. Economic too, but often linked to politics, so they [the second generation] are aware of the issue. They are not all politicised, but they want to become involved, in whatever manner, for the people.

As evidenced by this interviewee, what is reflective of the transnational social reality and diaspora space in which the secondgeneration members are embedded is the way they made sense of major events that had taken place both in the host society and in the homeland, yet which were to some extent linked to the larger geopolitical struggles concerning the Kurdish people. Evidently, not all members of the second generation of Kurdish parentage were similarly concerned or related to the events that took place in Kobane or in Paris, but at the same time Kobane was invoked and spoken of with emotion by all interviewees. Regardless of the heterogeneity among the respondents, it is possible to distinguish significant commonalities in how Kobane was experienced and what emotions and actions it evoked. They also talked about 'Kurdishness' in relation to it in a rather similar manner. Combined with the importance of the online spaces and the tradition of diaspora mobilisation, the Kobane siege also seemed to evoke a kinship connection (although it should not only be analysed in those terms). To conceptualise these similarities, I have used the term diasporic consciousness, which was manifested in the interviewees' accounts. 
One reason that the political disturbances in Turkey touched second-generation members directly was that they had family members living in the region. One interviewee explained the interest the second generation had towards Kobane and the situation in Turkey as follows:

MT: So, do the youth feel more implicated by what is taking place in Turkey and in Kobane, for instance, in Rojava ...?

Interviewee: Of course, our generation, if we are more interested in what is taking place there, it is because our families are in the front lines. Even if we live here, we follow the politics back there. If there's a dictatorship in Mali, it won't interest us, because we know nobody back there. But if there is a dictatorship in Turkey, the first people to be touched by it are our families, our uncles, aunts, cousins and it is for us to do something about it.

This is quite telling of the transnational space in which the secondgeneration members were embedded and had grown up (Levitt 2009). I suggest that the Kobane siege and the visibility it received kindled some sort of a kinship connection to Kurdistan, in the sense that 'if there were a dictatorship in Mali, they would not have been as interested', to paraphrase the interviewee's words above. At the same time, only a very few interviewees had a Syrian Kurdish background, and most had therefore no direct kinship connections to Syrian Kurdistan. They still felt concerned by the Syrian Kurds' combat against ISIS and referred to the combat as 'we' as Kurds against ISIS. This echoes Schøtt's (2021 forthcoming: 226-228) observations on deterritorial solidarity evoked by the Kobane siege, which she refers to as 'alterterritorial identification'. Indeed, the interviewees referred to a common 'Kurdishness', a pan-Kurdish identity in a sense, all the while acknowledging the heterogeneous demographics and politics concerning the Kurdish populations.

I argue that second-generation Kurds drew from a sense of diasporic consciousness ${ }^{134}$ that characterised their motivations to 
take part transnationally and to mobilise for Kobane. Firstly, this sense of diasporic consciousness was visible in how they narrated their parents' reasons to migrate and how their lives had been shaped by those decisions. For instance, Baser (2011) observes how the Kurdish second-generation members often manifest a consciousness of the traumas and violence experienced by their parents. This was also visible in this study, as several interviewees referred to the sacrifices and traumatic experiences their parents had gone through to be able to raise their families in safety. Secondly, it was also visible in ways of talking about Kurdistan, of the continuous lack of self-determination for Kurdish people and of Kurds facing ISIS, which made the conflict appear more tangible. In other words, the sense of diasporic consciousness was rooted in exilic memory. For instance, Weinzimmer (2008) has studied the relationship between ethnic identity and conflict among first- and second-generation Jewish Israeli Americans and Palestinian Americans. Concerning the generational differences, she concludes that the first-generation Jewish Israeli Americans and Palestinian Americans had a stronger connection to the conflict owing to their lived experiences of the conflict setting. For the second generation, born and raised in the United States, she discovered that they also strongly felt concerned by the ongoing conflict, but what shaped their concern were the shared memories and first-hand stories by their parents. This was also the case in this study.

Thirdly, the diasporic consciousness was visible in the wish to contribute to Kurdistan, expressed by a large majority of the interviewees. For instance, one interviewee thought about moving to the region to 'give back to people'. She considered herself lucky to have had the chance to complete her education.

Even in Rojava, a concrete thing for me would be to go and settle there and not just settle, but to work for the benefit of people. I have had the chance to complete my studies with good teachers who have supported and helped me ... I want to give back to people. It's not even a wish; it's a need to transmit my knowledge because I was lucky ... 
Several accounts also showed how there was a will to contribute either at distance or by temporarily moving to Kurdistan. For instance, one interviewee told of his educational and professional choices in relation to his wish to contribute to Kurdistan. He had chosen to work in the field of chemistry, through which he considered himself able to contribute to health, environment and so forth. And, most importantly, he had chosen this field of study as it enabled him to take part in knowledge transfer at a distance. As he noted, 'I don't need to be there myself, but I can do things that have an impact there. I have discussed this aspect at more length elsewhere (Toivanen 2019).

In fact, having chosen one's field of study or profession with the motivation to contribute to Kurdistan was not exceptional in the overall material, thus evidencing a sense of diasporic consciousness. These three aspects - perceiving one's life story as part of the family's exilic past, narratives about the situation of Kurds in Kurdistan, and the wish to contribute became part of a larger narrative - were shown by the interviewee below:

I started medical studies after high school because I was interested in it and also because I asked myself how I could help my country of origin, Kurdistan, in my own way. I wanted to become a humanitarian doctor and return there to help people. That's why I chose medicine. And, before entering university, my choices were guided by that wish, because my father also arrived here after having political problems in Turkey.

What was striking among the interviewees' accounts was that the large majority voiced a sense of duty to act and to contribute to the Kurdish cause, either through associations or even through everyday 'resistance' by speaking Kurdish. In this sense, the diasporic consciousness was rooted in 'diasporic memory'. I draw from Marianne Hirsch's (2008) conceptualisation of the second generation's memory as postmemory that characterises secondgeneration members' experiences in growing up with narratives that are shaped by traumatic events of their parents. In her study on Holocaust survivors in the United States, Hirsch also combines 
postmemory with the diasporic experience, in saying that 'The children of exiled survivors, although they have not themselves lived through the trauma of banishment and forcible separation from home and the destruction of that home, remain marked by their parents' experiences' (1997: 243). This consciousness of their parents' experiences was visible in narrations such as the one below:

I'm telling myself that there are too many people, who are persecuted and who have died back there. For me it's a duty, to speak up, to share all the information. It's a duty towards them, who are still there. And why we have come to Europe, is to be able to express ourselves, not to remain silent like our parents were back there. For me, that's the objective of the second generation. So that we can speak up through cultural stuff, through associations, in our studies, even in everyday life by speaking Kurdish ...

This interviewee made reference to the role of the second generation. This diasporic consciousness was present in the understandings of the second generation's role in Europe vis-à-vis the development of Kurdistan. The second generation was considered to have a crucial role in terms of contributing towards the region and in building bridges between France and Kurdistan. One interviewee highlighted the role of the second generation as building bridges between the diaspora and Kurdistan. The role of the diaspora was seen as being vigilant about what takes place in Kurdistan, and communicating concerns over human rights violations, for instance, to non-diaspora audiences and actors.

Back there, nobody can talk, but now if there's the slightest thing, everybody talks about it. Because we are everywhere, so they are no longer so free to do whatever they please. So that's the role of the diaspora. The diaspora passes information to the entire world, and it bothers them that we are everywhere. They have no power over us.

At the same time, their claims-making evoked their belonging to France. Hess and Korf (2014), in their study on second-generation 
Tamils' political mobilisation in Switzerland, observe that the mobilisation was a sort of 'homecoming' that spanned several identity politics, including being a Tamil, being Swiss and being Tamil in Switzerland. They further note that: 'this politics of affect generated a double reaffirmation of identification - with their Tamil origins and with the Swiss host society, but also a double identification crisis' that was about the host society's indifference towards the conflict. This was echoed among second-generation Kurds as well. Evoking both identities, they considered the Western countries' approach towards the Kurdish question ambivalent and the relationship fostered by the European Union countries, including specifically by France, towards Turkey hypocritical.

The engagement in political activities or in cultural events that raised awareness for the Kurds' situation in the Middle East was associated with a sense of responsibility to contribute to Kurdistan. As shown also by interviewees' accounts, this sense of duty to contribute stemmed from the consciousness of their own privileged position compared to the local population in Kurdistan, and it was narrated in relation to diasporic postmemory. It has been suggested that the experiences of second-generation members originating from families with refugee backgrounds can differ considerably from those whose families' settlement to a new society was not a result of forced migration (Chimienti et al. 2019). This consciousness of the forced migration background of their parents was visible in the narrated motivations to contribute to Kurdistan, thus indicating the impact of having grown up in a diaspora space that included collective and personal narratives of exile, displacement, 'homeland' and the Kurdish struggle for self-determination.

\subsection{Other Dynamics}

In the previous section, I discussed how second-generation members' transnational engagements and mobilisations were narrated in relation to constructions of 'Kurdishness' and the 'homeland'. I argued that the Kobane siege kindled some sort of kinship 
connection towards Kurdistan, witnessed in the diasporic consciousness visible in their narrations. However, there is simultaneously a risk of reducing and essentialising the transnational participation and mobilisations by second-generation members if such participation is merely treated as an indicator of belonging or non-belonging to a national community, and taken as a reflection of their assumed identity formation, integration or the lack thereof.

Brubaker (2002: 164) has argued that there is a need to move beyond such 'groupism'. By this he refers to the tendency to approach ethnic/racial groups as 'substantial entities to which interests and agency can be attributed'. As he rightly notes, attempts to understand the social world through the division of individuals into different groups is what should be under scrutiny, not the way to scrutinise it. As he (2002: 165) puts it, this tendency 'belongs to our empirical data, not to our analytical toolkit'. Also, Dahinden (2016) pleads for the 'de-migratization' of migration studies. By this she refers to the growing number of researchers who have called for a reassessment of the nation-state- and ethnicitycentred approaches to migration-related phenomena (Bommes \& Thränhardt 2010; Pries 2005; Wimmer \& Glick Schiller 2002). She demonstrates how 'migration-related difference is naturally given, even while trying to be critical of this paradigm' and offers three potential strategies to rectify this. She suggests clearly distinguishing between common-sense and analytical categories (similarly to Brubaker), bringing migration theory into closer communication with other social science theories and reorientating the focus away from 'migrant populations' towards 'overall populations' (Dahinden 2016: 2208-2209). In other words, we would miss a great deal of the complexity of second-generation members' mobilisation were we to conclude that the Kobane siege sparked an interest among second-generation members simply because they identified themselves in ethnic/national terms as 'Kurdish'. The question, then, is what else to consider to better understand the motivations of second-generation Kurds to engage towards Kurdistan, besides understanding them as a manifestation of diasporic consciousness. 
Concerning the research on second generation of migrant parentage, Anthias (2012: 103) has observed that the generational perspective 'often retains a national paradigm for understanding migrant adaptation and incorporation'. She suggests that, instead of studying variations between different generations as originating from where they were born, several differences between the first and the second generation can be linked to stages in the life cycle and age. In this study, this is exactly what I have attempted to do. Instead of treating the categories 'second-generation' and 'Kurds' as homogeneous entities with clearly demarcated boundaries, I have aimed to move beyond the tendency to treat these categorisations as taken for granted, and instead paid attention to the heterogeneity and analytical tools that allow the capturing of dynamics other that those deducible to the 'ethnic' or 'diaspora' context. Therefore, here I will follow two lines of analysis that were visible in the second-generation members' narrations, 'generation' (understood also as an age group) and the local/global context.

\subsubsection{Generation}

What is common in migration studies is to approach 'generation' from the perspective of migration experience. Indeed, the migration literature is replete with references to the 'first', 'second' and 'third' generations (of migrants), with the first term referring to individuals who migrated as adults, the second to individuals born to migrant parents in the society of settlement, and the third to their descendants. The term 'second generation' is, therefore, usually used to refer to migrants' offspring and to individuals who have migrated in their childhood or early teenage years (see Rumbaut 2004).

However, different studies have suggested the need to consider the heterogeneity among the 'second generation'. For instance, Chimienti et al. (2020) have questioned to what extent the category 'second generation' is exclusionary, pointing out that children of refugees in particular have been lumped together within the broader analysis of the second generation. Also, Anthias 
(2012) has approached 'generation' as being fragmented by various social differences, including gender, class and racialisation, instead of taking it as a unitary category. In other words, such an understanding acknowledges that, regardless of belonging to a particular generation, second-generation members' lived experiences and transnational engagements are not unitary and reflect diverse outcomes. This also defies the construction of binary generational distinction between the first and second generations, which, according to Anthias (2012: 103),

often retains a national paradigm for understanding migrant adaptation and incorporation, seeing the processes purely in terms of those encountered in the country of settlement and other influences linked to what have been accumulated in the 'past' in their countries of origin.

So what analytical value does the term 'second generation' in the sense of migration then have? In a way, it allows narrowing down the focus to individuals who have been raised in a transnational space and who have arrived in the country of settlement at a fairly young age or who were born there. This was evidenced in the previous section with a discussion that highlighted the commonalities in narrations that can be traced back to having been raised in a transnational diaspora space. On the other hand, there are commonalities shared by members belonging to the second generation that can perhaps be better captured by diversifying the understanding of 'generation'. Secondly, Anthias (2012) argues that, instead of making the distinction between first and second generations only on the basis of where their members were born, the differences between the two can also be linked to age and life cycle. In other words, the demographic sense of the term as in belonging to the same age cohort also needs to be accounted for.

Thirdly, and perhaps more importantly for this book's focus, Anthias suggests that the political and economic changes taking place in a particular context and over time also affect people differently depending on at which stage they are in their lives. 
This gets us closer to the sociological or 'Mannheimian' (1952) understanding of 'generation', i.e. how certain events and societal developments have shaped the experiences of a particular age cohort. The combination of these three aspects when narrowing the focus on the 'second generation' can bring to the analysis insights that the generational lens in the sense of migration experience would not necessarily capture.

So how does the diaspora context intertwine with a more sociologically informed understanding of 'generation'? It can be through the transnational diaspora space that certain 'homeland' events and societal developments become communicated and transmitted in the form of powerful narratives that reach secondgeneration members and that can eventually constitute a generational experience. One such example was the 'Kobane momentum'. One line of analysis would be to treat second-generation Kurds' transnational attachments and activities, or mobilisations, solely as identity-driven phenomena towards the ancestral 'homeland', Kurdistan. Indeed, the Kobane siege did evoke a sense of kinship connection towards the conflict, but there seemed to be more to it. As one interviewee explained, witnessing the Kobane siege had been a generational experience:

For instance, between 2013 and 2015, it was the Kobane generation. I still remember in 2009 , there was the Oramar generation, the great military offensive that Turkey launched against the PKK. ${ }^{135}$

Indeed, it seemed that Kobane was a generational experience in the sociological sense. Concerning the Kurdish diaspora, the role that second-generation members play in (diaspora) politics has been less studied than that of their parents (see Baser 2012; Mügge 2010), although several authors have expressed the need to pay attention to the importance of the generational dynamics in transnational participation and mobilisation (Alinia \& Eliassi 2014; Baser 2015a; Baser, Emanuelsson \& Toivanen 2015). However, even fewer studies have dealt with the notion of generation in a sociological sense, i.e. how certain events and societal 
developments have shaped the experiences of a particular age cohort. This is all the more significant in this case, as the respondents were part of the same generation in the demographic sense of the word (belonging to the same age cohort), in the sense often dealt with in the migration research literature (belonging to the second generation of migrant parentage), and lastly in the sociological (or in 'Mannheimian') sense of the word, meaning that they have shared both the 'Kobane momentum' and the impact of the assassinations in Paris on the local community.

One interviewee noted that there had been growing discontent among young people even before Kobane and that the Kobane siege operated as a trigger to channel the discontent that secondgeneration members felt. He explained the significance of Kobane as a triggering event:

I think that it was already in their minds, they wanted to do something but they had not been any triggering event, so I think Kobane was that, but it does not mean that there was nothing before that.

This also speaks to the earlier observations about the political discontent among young people in general. What seemed to speak to many second-generation members was the societal experiment taking place in Rojava and how its main ideological premises echoed among young Kurds. For instance, one interviewee affiliated with a pro-PKK movement emphasised the relevance of the Rojava experiment beyond the boundaries of Syrian Kurdistan, stating that it was simultaneously a 'conflict and a sort of a revolution together'. He specifically underlined the ideological basis of the experiment, and considered it a radical departure from the capitalist system, the 'old models' and the status quo (Colasanti et al. 2018):

The aim is to make it for everyone. Today, what's taking place in Rojava is that the combat is becoming internationalised. The Middle East is perfect for that, since there's chaos and that 
allows to put in place that type of system. So what is the PKK doing today? They are giving another way to see the world, other model for a society. We combat people who want to preserve the status quo, the old models and their old interests, capitalism in all its splendour.

Another interviewee, who was not politically affiliated but found the societal experiment in Rojava fascinating, associated the second-generation Kurds' interest towards Rojava with the fact that the French political scene did not evoke great emotions for them.

People discovered the Kurdish combat via Kurds in Syria. At the same time, the French political scene does not awake big motions for young Kurds, not like the combat in Kobane that has opened the minds for the cause of Rojava.

In this sense, the interest towards Rojava did not seem to be (only) inscribed into and explicable via the kinship connection towards Kurdistan, but also by more general political discontent and by criticism of the existing political/societal models and ways of thinking, as discussed earlier. It seemed to be an added pride that the societal experiment was led by Kurds in Syria, but simultaneously it was emphasised that it was not meant only for the Kurdish populations. Including a more sociological (and demographic) approach to generation also allows mobilisation processes to be considered from a de-ethnicised perspective and shed light on aspects of diaspora contributions that have previously been left in the shadows. This enables the recognition that mobilisation processes and political activism do not necessarily only concern particular diaspora groups but that they can also concern ethnic minority youth across ethnic boundaries, or simply individuals whose parents and ancestors are not part of diasporic movements. This leads us to take into account the dynamics of the political and societal context in which this generation has grown up. 


\subsubsection{Global cities, glocal constellations}

As stated earlier, one must avoid the temptation of making assumptions that are too straightforward between secondgeneration participation in diaspora politics and their assumed diasporic identity. Whereas identity and a sense of belonging have been shown to play a part in second-generation mobilisations (Hess \& Korf 2014), second-generation mobilisation can also reflect broader transformations in political repertoires and ways to engage simultaneously at the local level, yet via activities that entail a transnational (yet not necessarily a diasporic) dimension. Indeed, second-generation members' transnational activities can be 'glocal' in the sense that they reflect larger political transformations currently taking place and become narrated through global political issues, even though they take localised forms (Wieviorka 2005). For instance, one interviewee explained his preference of politics in the following manner:

MT: So, would you like to be politically engaged towards French politics, or ...?

Interviewee: I hesitate ... Because I'm based in France, it would be a European thing. So either it's a European thing that I'll do or a Turkish thing, but something completely French ... When I see the political debate in France today, I'm not really interested. I cannot see what I could do. I think Turkey is much more interesting than France. And if I do a European thing, it's to help the Kurds, to help the Kurds in France to have good relations.

This is similar to O'Toole and Gale's observations (2010) in their study on ethnic minority youth in Britain, where they found evidence of changing political subjectivities that are to some extent based on the 'glocal connections' that ethnic minority youth foster. In a way that is different from diasporic and transnational connections, they suggest that 'new grammars of political action' are 'glocal' in the way that local spaces are conceived in relation to awareness of global political issues, and this has been enabled through access to international media outlets and active engagement 
in internet-based publics' (p. 128). ${ }^{136}$ In this study, the motivations for such translocal activism were narrated in relation to discourses and more global calls for political and social change, for social justice, equality, sustainable environmental policies and minority rights. These were visible in the motivations of second-generation members to engage politically in a way that moves beyond 'homeland' motivation. The emphasis was on the commonality as 'human'. One interviewee explained the applicable nature of Öcalan's ideas beyond the Kurdish societies. He also emphasised that such ideas included the rejection of the nation-state with boundaries and a flag, contrasting it with the nation-state models in France and the United Kingdom:

If the ideas of Öcalan started to be applied in societies, totally human ideas, he speaks very little of Kurds, and instead he talks of peoples, democracies, of freer and just societies. If we could only work together as human beings and move beyond the idea of an independent nation-state with boundaries, a flag, a language. You know, the idea taken by the Jacobin French, by the British, which does not work at all ... Boundaries only kill people.

Indeed, some respondents also voiced criticism towards the nationstate system (and capitalism), echoing the political discourses of Syrian Kurdish political actors (Dinc 2020) but perhaps also echoing the critical sentiments towards the role of nation(-state) and national identities of that particular age group in general (see Ross 2019). In fact, Anthias (2012: 104) notes that, if individuals, regardless of their origin or migration trajectories, are considered to inhabit transnational spaces and continue have bonds with homelands and other localities, it becomes easier to discern what is a shared experience and what is not. She mentions multicultural cities as one example of such transnational spaces that are shared by those belonging to the dominant majority and those belonging to minorities (albeit differently because of asymmetrical power structures).

For instance, the significance of urban political spaces and cultures in global cities such as Paris that structure (diaspora) politics 
and shape mechanisms for collective action is undeniable. Indeed, the significance of global and urban spaces to changing political landscapes and subjectivities is an important factor that needs to be accounted for in any analysis on political (dis)engagement in the new millennium. Concerning this, I find Sassen's (2005: 39) observations on transnational politics particularly pertinent. When talking about the 'global city' she notes that:

insofar as the national as contained of social process and power is cracked, it opens up possibilities for a geography of politics that links sub-national spaces across borders. Cities are foremost in this new geography. This engenders questions of how and whether we are seeing the formation of a new type of transnational politics that localizes in these cities.

At the same time, the global context of cities and urban spaces is also important to diasporic mobilisations. Diasporas (and to some extent diaspora politics) fit quite nicely into this picture, as 'global cities' such as London, Berlin, Paris and many others have been the contexts to understand diaspora politics. Or, as Adamson (2016: 297) notes, 'the networked structure of diasporas means that they are ideally situated to inhabit new "non-national" political spaces such as global cities and cyberspace. Among other global capitals, Adamson (2016: 296) lists Paris as an example of a global city that has become site for coordinated, transnational diaspora politics. This provides the means for diaspora actors to tap into new forms of global identity politics, by framing their political agendas in terms of more global struggles, such as struggles for social justice and equality. This was also visible in this study, as discussed in the previous section, in instances where the respondents emphasised the universal value of the Rojava model for other peoples too.

This study pointed also toward transnational elements in how the collective action was organised and to what Della Porta and Tarrow (2005) have called transnational social action. By this, they refer to 'coordinated international campaigns on part of networks of activists against international actors, other states, or international institutions' (pp. 2-3). The year after the Kobane siege (2014-2015), 
in 2016 the French social movement Nuit Debout (Up All Night) brought protesters to the Place de la République, in Paris. The movement rose out of protests against the labour reforms and soon became a protest for anti-austerity measures in general, similarly to the Los Indignados movement in Spain or even the global Occupy movement that started off in the United States. I visited the square on several occasions and was able to witness diaspora organisations' presence among French NGOs and other civil society actors. One particular banner emphasised the transnational dimension of the protest, titled "De Calais à Barcelone, de Paris à Kobané. La solidarité avec les revoltes”. It made reference to solidarity with protests from the refugee camps in Calais, to the Indignados movement in Spain and finally to Kobane.

Indeed, this study points towards the need to take into account the new refashioning of the political (Norris 2002: 128), but also how 'local spaces are conceived in relation to the awareness of global political issues' that have been enabled 'through access to international media outlets and active engagement in internet-based publics'. This adds another spin on the discussion on methodological nationalism and transnationalism that started this chapter. In the words of Anthias (2009), it also highlights 'the need for a contextual, dynamic and processual analysis that recognises the saliency of different social ontologies at the local, national, transnational and global levels and their interconnectedness within social relations in terms of processes and outcomes'. A different picture emerges when examining transnational (diaspora) political action and mobilisation processes from perspectives that depart from methodologically nationalist and 'groupist' interpretations, allowing us to understand them (also) as something beyond diasporic. 



\section{Conclusion}

This book examined how a series of events that took place in the Middle East, Turkey and France in the 2010s have resonated in Kurdish diaspora communities in France. Critical events, such as the Kobane siege (2014-2015), have mobilised diaspora communities and their members in a multitude of ways and led to different forms of participation towards Kurdistan. I have argued that, in particular, the Kobane siege and the assassination of three Kurdish activists in 2013 were transformative events in the sense that they had a multiplying effect towards the diasporic mobilisations. I suggest that they were turning points in the sense that they mobilised more 'dormant' members, although it remains an open question whether this has led to transnational engagements and activities of a more sustainable nature.

These transformative events were also particular in the sense that, unlike the majority of previous case studies dealing with diasporic mobilisations, ${ }^{137}$ the assassination of Kurdish activists took place in Paris and not in the Kurdish territories. This meant that the homeland dynamics became conflated with host society dynamics through such transformative events that touched upon both settings. This dynamic consequently shaped the ways diaspora actors formulated claims and what narratives and discourses were employed to frame such claims. For instance, Kurdish diaspora actors were increasingly vocal towards the national actors in France, particularly after the assassination of the three Kurdish 
activists that took place on French soil, as well as after the ISIS attacks that touched France in 2015, which presumably made the national interlocutors seem more receptive to diasporic claims concerning the Kurds' combat against ISIS.

Simultaneously, there seemed to be a broader change in Kurdish diaspora activism across Europe in the sense that diasporic claims were increasingly made to the European policymakers, building on the already-existing alliances and networks that Kurdish political actors had in Brussels (Casier 2011; Eccarius-Kelly 2017). Indeed, diaspora actors simultaneously addressed EU-level interlocutors as well as local actors to raise awareness of the ongoing conflict. Through the examination of how diasporic claims were made, projects articulated or even loyalties evoked and mobilised, this book also shows how the Kurdish (diaspora) nation became constructed as an actor that appealed to its relational others, in this case the French government and European institutions, and one that opposed the treatment of Kurds by ISIS or by Turkey, thus increasing its legitimacy as a potential interlocutor on the international political scene.

Throughout the past decades, the Kurdish diaspora actors have fostered dense networks and linkages that expand to the transnational space. In this sense, the diasporic mobilisations in the 2010s could lean on existing alliances, networks and organisational structures that facilitated diaspora members' engagement in a variety of transnational political action, including transnational electoral, organisational and semi-institutional (cultural) activities. Therefore, even though mobilisations are fuelled and shaped by 'transformative' events that can take place in both the homeland and host country contexts, their success is also based on different political opportunity structures, mobilising structures and practices (including networks) and the capacity to frame the transformative events in a way that they speak to diaspora members. In this case, the host society context together with the transnational political opportunity structures, including particularly the networks of local NGOs and the Kurdish diaspora actors' tradition of appealing to European political institutions 
(Casier 2011), were enabling factors in diasporic mobilisation. Another enabling factor was how the Kurds' combat against ISIS was framed, both by key diaspora actors, or what Adamson (2013: 69; see Baser 2015a: 33-34) calls transnational brokers, and by the international media.

The siege of Kobane received unprecedented media visibility that threw the Kurds into the international spotlight. The media frames depicted Kurds as the heroic defenders of human rights and liberal values and quickly became contrasted with the barbarous deeds committed by ISIS in the region. This positive media visibility led to the mobilisation of global support for Kurds (Kardaş \& Yesiltaş 2017). The role of female Kurdish combatants fighting off ISIS was particularly emphasised in the international press (Toivanen \& Baser 2016). This largely positive media visibility, and political support by Western countries, however, stood in stark contrast to the criminalisation of the PKK, an organisation that had close ties with the celebrated Syrian Kurdish forces but that nevertheless featured in the EU's and United States' lists of terrorist organisations. The diasporic claims and stances were, thus, also formulated in the context of political ambivalence towards the pro-PKK movement, also because the organisation had considerable mobilisation power through its transnationalnetworkstomobiliseKurdish diasporacommunities in Europe, and in particular in France (Grojean 2015; Jongerden \& Akkaya 2016).

Whereas the first part of the analysis focused on the overall Kurdish diasporic mobilisations as they took place in the 2010s in Paris, the second part narrowed down the focus to the second generation and examined in particular the significance of the Kobane siege for young second-generation Kurds. The second-generation members took part in activities that included participation in demonstrations, electoral activities and humanitarian convoys. They also engaged via online spaces, translated and blogged on the Kurdish combat, and organised and took part in awarenessraising campaigns and seminars. In a few cases, such transnational activities included also short-term visits to the region. 
Second-generation members' mobilisations constituted of activities that were transnationally orientated and simultaneously locally bound: they mobilised through student associations, leftist networks in Paris and NGOs and often via means other than merely diaspora organisations. Their activities were translocal in the sense that they were locally bound in terms of organisation and targeted audiences but simultaneously linked to the political situation in the Kurdish territories. At the same time, they were considered to be less engaged than their parents and expressed a discontent towards politics. Such accounts echoed findings conducted more generally on the younger age groups in Europe (Bennett 2008; Dalton 2017; Furlong \& Cartmel 2007; Inglehart \& Welzel 2005; Sloam \& Henn 2019). They also understood 'political' to refer to more traditional forms of (diaspora) party politics and, for instance, did not consider their daily online activities to be political. The online activities did, on the other hand, contribute to constructing their relationship towards Kurdistan. In that sense, both 'offline' and online activities were inscribed into a sense of diasporic consciousness towards the ancestral 'homeland'.

However, there was more to it. I have also argued in this book that there is a need to include other dynamics at play if we are to fully understand political (dis)engagements among youth with migrant parentage. Generation constituted the central theme throughout this book, as indicated by the title. In addition to acknowledging the significance of second-generation members being raised in transnational social realities and in a diaspora context, I focused particularly on two lines of analysis. The first was understanding 'generation' in a sociological, demographic and 'migrant' sense of the term, and the second discussing the significance of the local, global and diaspora context. Leaning on these aspects, this book shows how the Kobane generation came into being and how it manifested itself in the midst of the Kurdish diasporic mobilisations in Paris in the 2010s. The Kobane siege was a generational experience.

Indeed, another picture emerges if we are to consider secondgeneration members' mobilisation and political (dis)engagement 
in relation to studies that have been conducted on young adults' political activism in general. They show that young adults' repertoires of action reflect more global changes in political subjectivities, including technological changes that modern societies are going through and the changing understandings of what 'political' means (Mahéo, Dejaeghere \& Stolle 2012; O’Toole \& Gale 2013; Sloam \& Henn 2019). In other words, the ways younger generations engage in civic and political activism are rapidly changing, and this change naturally also touches upon young people of migrant parentage.

Why is this important? I suggest that, if we are to fully understand the role subsequent generations can play towards ancestral 'homeland' development, we need to move beyond considering potential contributions only through the 'diaspora' or 'ethnic' lens. This allows us to grasp the myriad ways subsequent generations take part in translocal activism and to understand the underlying motivations for it that can include other aspects than those merely deducible to the diaspora context. One such example of this was the way second-generation Kurds were inspired by Rojava's societal experiment and its ideological basis, which they perceived to transcend ethnic division lines. Another example was the heterogeneity in ways second-generation members engaged towards the ancestral 'homeland' - both via institutional means and individually.

These aspects deserve more attention in future research in order to gain a better understanding of the role the second generation can play towards diaspora contributions. It also remains the task of future research to examine how intergenerational transmissions and conflicts co-exist in migrant families, how those shape the reproduction of old repertoires of actions and the invention of new ones, and how second-generation members' experiences and modalities of action are inscribed into different temporalities and spaces that can be simultaneously both diasporic and non-diasporic. 



\section{Appendix: Methodology}

\section{Material and Methods}

The book is based on empirical data mainly collected between 2015 and 2017 in France. The overall material consists of four different data sets, the main corpus of the material consisting of interviews, which were conducted in French. The data citations used are translated by the author.

1.The first set of data consists of qualitative interviews and informal discussions with first-generation Kurds, as well with members and activists in different diaspora organisations $(n=20)$. The interviews were semi-structured and thematic, focusing in the case of firstgeneration Kurds on the mobilisation processes in Paris and on diaspora organisations' scope of activities, transnational connections and engagements, and overall on the question of how the interviewees considered that different events back 'home' resonated in the diaspora and possibly generated mobilisation among its members. The informal discussions also included these themes. I interviewed firstgeneration migrants who had arrived in the country in the $1980 \mathrm{~s}$ and 1990s.

2. The second set of data consists of qualitative interviews with second-generation members $(\mathrm{n}=30)$ of Kurdish background in Paris. I interviewed diaspora members who were active in the diaspora organisations, but also ones who did not engage in organisational activities. In addition to the mobilisation processes, in the case of 
the second generation the interview themes also included questions on their life stories, transnational activities and engagements, educational choices and language skills, questions of identity and belonging, and future plans. The interviews were conducted with second-generation members who were born in France (or arrived very young) and who were aged at the time of interviews between 19 and 35 years old. All respondents, both first- and second-generation members, lived in Paris or the Greater Paris region.

3. The third set of data includes virtual material and online data collected from diaspora organisations' official websites and social networking sites (such as Facebook pages, Twitter accounts, blogs and online campaigns and possibly Instagram accounts). This methodological approach enabled the capturing of the virtual dimension of such activities and engagements. Furthermore, I completed a mapping of the relevant diaspora organisations through the sources available on the Internet, associations' databases and official reports.

4. The fourth and final set of data includes observation notes that I completed, alongside photographs, images and audio-visual material that I collected from a series of events (including but not limited to, demonstrations, cultural events, exhibitions, seminars and political meetings) in Paris between 2015 and 2017.

I have employed interviewing and participant observation as the main methods to collect the main body of the research material. The interview data collected was transcribed, processed with a computer-assisted qualitative analysis (Atlas.ti) and analysed with thematic analysis. The research participants were located by using snowballing sampling, and through various key persons, migrant organisations and cultural centres and with open interview invitations published on relevant websites or social media. Most interviewees came or had a background in Turkish Kurdistan, although some also traced their background to Iranian, Iraqi or Syrian Kurdistan.

My researcher positionality in France was that of an 'outsider' both to the Kurdish community and to the majority population, and it often evoked curiosity and even surprise of having undertaken such a research topic. Even though the political 
circumstances surrounding the Kurdish question in France during the data collection were somewhat sensible, coming from a relatively neutral Nordic country in terms of the Kurdish question my inquiries and participation in events were not met with suspicion or reservations. I have discussed this in more detail elsewhere (see Baser \& Toivanen 2018b).

\section{Ethical Considerations}

For the first and second data sets, the ethical questions related mainly to drafting the research design and research questions, different phases of the data-collection procedure including collecting the material, protecting and analysing it, and the preservation of the collected material and efforts to make the analysed material available to research participants. The research questions were drafted in a way that they represent a careful ethical consideration of the research participants' views and perceptions that are valorised. Similar attention was paid to the drafting of interview themes and the formulation of interview questions. The semi-structured interview structure was considered to provide the research participants with the most freedom and flexibility to provide answers to interview questions. The data was protected and preserved with utmost attention.

As for other ethical considerations, I have anonymised the interviews and opted to use pseudonyms. I informed the potential research participants of the research topic, design, purpose and distribution when they were first contacted. Their willingness to take part in the study was further confirmed at the beginning of the interviews. For the third data set, extreme care was put into the preservation of the collected material. In the analysis stage, I removed any recognisable characteristics from the data (age, background information on travels, family members etc.), particularly when using data excerpts. In cases when research material was collected from social networking sites that need to be accessed using a password, the purpose of the study and the presence of a researcher were made visible. In such cases, where (online) 
material was collected through observation, I paid particular attention to anonymity, confidentiality and data protection.

\section{On Naming}

Defining the region of Kurdistan and delineating who the Kurds are is a politically controversial issue owing to the complex geopolitics in the region. Naming is in no way innocent and it becomes an ethical issue for it attaches social meaning to geographical entities and peoples. When it comes to the Kurdish question, naming becomes particularly politicised. I have chosen to employ the term 'Kurdistan' to refer to the geographical region that covers the main areas inhabited by Kurdish speakers and refer to its specific parts within individual nation-states as 'Iraqi Kurdistan', 'Iranian Kurdistan', 'Syrian Kurdistan' and 'Turkish Kurdistan'. This seems to be common practice among scholars conducting research related to Kurds and Kurdistan (see Alinia 2004; Khayati 2008: 48; Natali 2005; Wahlbeck 1999: 7).

However, many Kurds also refer to Turkish Kurdistan as Northern Kurdistan (Bakûr), Iraqi Kurdistan as Southern Kurdistan (Başûr), Iranian Kurdistan as Eastern Kurdistan (Rojhelat) and Syrian Kurdistan as Western Kurdistan (Rojava), questioning the states' sovereignty explicitly when doing so. Currently, the part of northern Iraq where the de facto state of Iraqi Kurdistan has emerged seems to be referred to mainly as Iraqi Kurdistan, while, in contrast, the most commonly used term for Turkey's Kurdishinhabited regions tends to be 'south-east Turkey'. Rojava is also a term that has become more and more employed, for instance by the international media in reference to the Syrian Kurdish region. Common appellations for Kurds as a people refer to Kurds from Turkey, Iran and Iraq, because, as Wahlbeck (1999: 7) mentions, 'Turkish Kurd' and 'Iraqi Kurd' can be considered offensive.

Another controversial issue concerns the naming of Kurdish troops in Syria and Turkey. The PKK features on the European Union's list of terrorist organisations, although contestably so, and the Turkish media and politicians refer regularly to the 
organisation as a 'terrorist organisation'. I will employ the relatively neutral term 'combatant' in relation to the Kurdish fighters in northern Syria and eastern Turkey, instead of using terms such as 'terrorist', 'guerrilla' or 'freedom fighters' that have different connotations and political implications. I have also chosen to refer to the so-called Islamic State in the first instance as the so-called Islamic State, and from thereafter with the acronym ISIS instead of the Arabic acronym Daesh, which is in more common usage in France and was also used by most respondents. Similarly, I have also chosen to use the term Kobane, as it is the most common spelling in English, instead of using the Kurdish term, Kobanî, or the Arabic term, Ayn al-Arab. 



\section{Notes}

1 The UN Independent International Commission of Inquiry determined in 2016 that the ISIS attacks on Yezidis constituted a genocide.

2 See 'ISIS' Yazidi Genocide' (Foreign Affairs, June 8 2017, https://www .foreignaffairs.com/articles/syria/2017-06-08/isis-yazidi-genocide).

${ }^{3}$ See Sheema Khan, 'The Arab diaspora finds its voice' (The Globe and Mail, October 31 2002, https://www.theglobeandmail.com/opinion /the-arab-diaspora-finds-its-voice/article4243545).

${ }^{4}$ For instance, the EU-funded cooperation project Diasporas for Peace (DIASPEACE), which operated from 2008 till 2011, examined the activities of Eritrean, Ethiopian and Somali diaspora organisations in the political processes of the sending countries.

${ }^{5}$ See 'Turkish-Kurdish conflict spills over into Europe' (The Conversation, October 162015 https://theconversation.com/turkish-kurdish -conflict-spills-over-into-europe-47610).

${ }^{6}$ It is important to note that several Turkish cities, for instance, host large Kurdish communities and it has been said that the city with the largest number of Kurds is, in fact, Istanbul.

7 See William Safran, 'Concepts, Theories, and Challenges of Diaspora: A panoptic Approach' (SISSCO, September 18 2007, http://www.sissco .it/articoli/cantieri-di-storia-iv-391/programma-392/dispersione 
-globalizzazione-e-costruzione-dellalterita-diaspore-e-migrazioni -nel-bacino-del-mediterraneo-ed-oltre-xix-xx-sec-435/concepts-theo ries-and-challenges-of-diaspora-a-panoptic-approach-441).

${ }^{8}$ The debate (and scholarship) on transnationalism and generation has been closely related to the question of integration (or assimilation in the North American context) (see Waldinger 2015).

${ }^{9}$ This contextualisation section is to some extent based on the one in my PhD thesis, Negotiating Home and Belonging - Young Kurds in Finland (Toivanen 2014).

10 See: http://www.institutkurde.org/en/kurdorama

${ }^{11}$ Description of the linguistic breakdown of Kurdistan can be found at http://www.institutkurde.org/images/cartes_and_maps/linguistic _composition.jpg.

${ }^{12}$ Hassanpour (2012) discusses the dialectical fragmentation of the Kurdish language, along with the conflict over the adoption of Sorani and Kurmanji as the official standard languages of Iraq.

${ }^{13}$ See 'Rojava administration launches new curriculum in Kurdish, Arabic and Assyrian' (ARA News, October 7 2016, http://aranews .net/2016/10/rojava-administration-launches-new-education-system -kurdish-arabic-assyrian-2).

${ }^{14}$ See also Martin van Bruinessen's piece 'The ethnic identity of the Kurds in Turkey', at http://www.hum.uu.nl/medewerkers/m.vanbru inessen/publications/Bruinessen_Ethnic_identity_Kurds.pdf.

${ }^{15}$ The relationship of the Kemalist philosophy to religion is somewhat more complex. It did incorporate religion (Sunni Islam) into the notions of national identity and employed it at times to forge a sense of national unity. A good example of identities' basis in religion can be found in the population exchanges of Greek Orthodox citizens of Turkey and the Muslim citizens of Greece in the 1920s, which were based on religion and not so much on language or the people's ethnic identities (see Insel 2007).

${ }^{16}$ For Turkey, see Uppsala Conflict Database at https://ucdp.uu.se /country/640.

${ }_{17}$ Anfal refers to the 'spoils of war' and has its origin in one of the surahs in the Quran.

${ }^{18}$ Elaine Sciolino, 'Kurdish Chief Gains Support in U.S. Visit' (New York Times, 22 June 1988).

${ }^{19}$ If one wishes to gain a comprehensive understanding on the events taking place in the Kurdish regions and on those touching upon the Kurdish populations, the bulletin of the Kurdish Institute offers 
an excellent archive on such news stories published from 1998 onward. See https://www.institutkurde.org/en/publications/bulletins /list.php.

${ }^{20}$ See 'The Kurdish National Council in Syria' (Carnegie Middle East Center, February 15 2012, https://carnegie-mec.org/diwan/48502).

${ }^{21}$ See 'Kurdish People's Protection Unit YPG' (Global Security, http:// www.globalsecurity.org/military/world/para/ypg.htm).

${ }^{22}$ For instance, CNN featured Kurdish female fighters in their news story together with, for instance, Nobel Peace Prize winner Malala Yousafzai. See 'Your Leading Women of 2014' (CNN, December 10, 2014, http://edition.cnn.com/2014/12/19/business/gallery/leading -women-2014/index.html).

${ }^{23}$ See 'Thousands Protest in Turkey to Show Solidarity with Kobane Kurds' (Middle East Eye, 13 February 2015, https://www.middlee asteye.net/news/thousands-protest-turkey-show-solidarity-kobane -kurds).

${ }^{24}$ See Michael M. Gunter, 'The Closing of Turkey's Kurdish Opening' (Journal of International Affairs, 20 September 2012, https://jia.sipa .columbia.edu/online-articles/closing-turkey\%E2\%80\%99s-kurdish -opening). On freedom of the press in Turkey, see https://www.free domhouse.org/sites/default/files/Turkey\%202012.pdf.

${ }^{25}$ See 'Iraqi Kurdish Reinforcements Arrive to Defend Kobane' (Al-Jazeera, 1 January 2014, http://america.aljazeera.com/articles /2014/11/1/peshmerga-arrivekobane.html.)

${ }^{26}$ For a detailed account on the dispersion of the Kurds in premodern times and in the early 20th century, please see Hassanpour \& Mojab (2005: 215-217).

${ }^{27}$ From the database of the Norwegian Refugee Council (2005), 'IDP: Profile of Internal Displacement: Turkey', 50-51, http://www .internal-displacement.org/8025708F004BE3B1/(httpInfoFiles) /A0D784C014878D59802570BA00568E64/\$file/Turkey\%20-October \%202005.pdf.

${ }^{28}$ Van Bruinessen refers to the Turkish daily Cumhuriyet, which on 12 February 1986 reported the findings from the opposition party's fact-finding mission to eastern Turkey.

${ }^{29}$ See 'Some 800 Victims of Enforced Disappearance Remembered' (EnforcedDisappearancesInformationExchangeCenter,22May2008, https://web.archive.org/web/20110402083838/http://www.ediec .org/news/newsitem/article/turkey-some-800-victims-of-enforced -disappearance-remembered). 
${ }^{30}$ See 'Kurdish “Grave Site” Digs Begin' (BBC, 9 March 2009, http:// news.bbc.co.uk/2/hi/7932792.stm).

${ }^{31}$ See 'Le 24 septembre ensemble avec "les Mères du Samedi"' (Kedistan, 24 September 2016, http://www.kedistan.net/2016/09/21/24-septembre -avec-les-meres-du-samedi).

${ }^{32}$ See 'Diaspora kurde' (Institut kurde de Paris (Kurdish Institute of Paris), 2016, https://www.institutkurde.org/info/diaspora-kurde $-1232550920)$.

${ }^{33}$ See 'Kurdish Diaspora' (Institut kurde de Paris (Kurdish Institute of Paris), 2016, https://www.institutkurde.org/en/info/kurdish-diaspora -1232550988).

${ }^{34}$ See 'The Kurdish Population' (Institut kurde de Paris (Kurdish Institute of Paris), 2017, https://www.institutkurde.org/en/info/the -kurdish-population-1232551004).

${ }^{35}$ See 'Who Is the Kurdish Institute?' (Institut kurde de Paris (Kurdish Institute of Paris), 2016, https://www.institutkurde.org/en/info/who -is-the-kurdish-institute-s-1232550990).

${ }^{36}$ The first federation of Kurdish associations in Europe was the KOMKAR, which was affiliated with the PSK (Kurdistan Socialist Party of Turkey) and which distanced itself from the PKK due to differing views on the usage of violence (Baser 2015c: 113-114). However, after the Turkish military coup, the PKK marginalised the PSK, and ironically in the 2000s came to adopt the non-violent strategy advocated earlier by the PKS (Gunter 2011: 189).

${ }^{37}$ See 'Qu'est-ce que le Conseil démocratique kurde en France ?' (Le Conseil démocratique kurde en France (the Democratic Kurdish Council of France), https://cdkf.fr/a-propos).

${ }^{38}$ See 'Kendal Nezan, l'homme qui parle kurde aux socialistes français'('Kendal Nezan, the Man Who Speaks Kurdish to French Socialists') (Slate, January 29 2015, http://www.slate.fr/story/97307 /kendal-nezan-kurde-socialistes-france).

${ }^{39}$ See 'Les processus d'intégration des Kurdes dans les pays de l'Union européenne' (Institut kurde de Paris (Kurdish Institute of Paris), 24 February 2006, https://www.institutkurde.org/conferences/integration _des_kurdes/Rusen+WERDI.html).

40 'Kendal Nezan, l'homme qui parle kurde aux socialistes français' (Slate, 29 January 2015), http://www.slate.fr/story/97307/kendal-nezan -kurde-socialistes-france.

41 'Visite de Madame Hidalgo à L'Institut kurde' (Institut kurde de Paris (Kurdish Institute of Paris), 17 October, 2014, https://kurde.eu/info /visite-de-madame-anne-hidalgo-a-lsinstitut-kurde-1232550816). 
${ }^{42}$ See 'Turquie - 15000 Kurdes à Strasbourg pour la libération d'Öcalan' (Ouest-France, 11 February 2017, http://www.ouest-france .fr/monde/turquie/turquie-15-000-kurdes-strasbourg-pour-la -liberation-d-ocalan-4795685) and 'Les Kurdes en marche sur les routes de Lorraine' (DirectFM, 3 February 2017, https://www.directfm .fr/news/les-kurdes-en-marche-sur-les-routes-de-lorraine-27538).

${ }^{43}$ Grojean and Massicard (2005: 6) note that even if the PKK has become, at least to some extent, the reference point within the Kurdish movement, it has never managed to impose a total monopoly on the Kurdish question, as is evidenced by the divisions concerning the Kurdish diaspora politics.

${ }^{44}$ The Kurdish diaspora in Sweden has been particularly active. Van Bruinessen (1999b: 10) has noted that the Kurdish diaspora in Sweden features a relatively high number of educated Kurds, including writers, journalists and other intellectuals. For instance, the Third World Kurdish Congress was held in Stockholm on 11-13 October 2013. The previous two such congresses were held in Amsterdam (2011) and Erbil, Iraq (2012).

${ }^{45}$ See 'Turkey slams Belgium court ruling that PKK is not a "terrorist" organisation' (Euronews, January 29 2020, https://www.euronews .com/2020/01/29/turkey-slams-belgium-court-ruling-that-pkk-are -not-terrorists-thecube).

${ }^{46}$ See 'British teenage girl charged with trying to join Kurdish forces fighting Isis' (The Guardian, 13 March 2015, https://www.theguardian .com/world/2015/mar/13/british-teenage-girl-charged-kurdish -forces-fighting-isis).

${ }^{47}$ See 'Top court backs Denmark in discontinuing licence for PKK TV channel' (European Centre for Press and Media Freedom, 11 June 2018, https://www.ecpmf.eu/archive/news/legal/top-court-backs -denmark-in-discontinuing-licence-for-pkk-tv-channel.html).

${ }^{48}$ See 'L'UE et la Turquie s'affrontent au sujet de la loi antiterroriste turque' (Le Monde, 12 May 2016, https://www.lemonde.fr/interna tional/article/2016/05/12/l-ue-et-la-turquie-s-affrontent-au-sujet -de-la-loi-antiterroriste-turque_4918381_3210.html).

${ }^{49}$ More information on Kevin Mc Kiernan's documentary on Roj, Good Kurds, Bad Kurds, at https://www.imdb.com/title/tt0233812/.

${ }^{50}$ I wish to emphasise that I am not taking a position towards the value of the PKK being designated as a 'terrorist' organisation, either legally or discursively. Instead, I focus on the ramifications of such a designation.

${ }^{51}$ See 'Immigrants by country of birth' (Institut national d'études démographiques, July 2020, https://www.ined.fr/en/everything_about 
_population/data/france/immigrants-foreigners/countries-birth -immigrants).

${ }^{52}$ See 'Lessentiel sur... les immigrés et les étrangers' (Institut national de la statistique et des études économiques, 7 April 2021, https:// www.insee.fr/fr/statistiques/3633212).

${ }^{53}$ See 'Être né en France d'un parent immigré' (Institut national de la statistique et des études économiques, 8 February 2017, https://insee .fr/fr/statistiques/2575541).

${ }^{54}$ See 'Kurdish Diaspora' (Institut kurde de Paris (Kurdish Institute of Paris), 2016, https://www.institutkurde.org/en/info/kurdish-diaspora -1232550988).

${ }^{55}$ See 'Les processus d'intégration des Kurdes dans les pays de l'Union européenne' (Institut kurde de Paris (Kurdish Institute of Paris), 24 February 2006, https://www.institutkurde.org/conferences/integration _des_kurdes/Rusen+WERDI.html).

${ }^{56}$ In 1999, a distinction was made between French by birth and French by naturalisation after harsh criticism.

${ }^{57}$ See 'Manuel Valls : «Oui, la France est en guerre contre le terrorisme »' (Le Monde, 13 January 2015, https://www.lemonde.fr/politique/article /2015/01/13/manuel-valls-oui-la-france-est-en-guerre-contre-le -terrorisme_4555301_823448.html).

${ }^{58}$ The 'fiche S' system was created in the late 1960s to facilitate searches on different individuals, missing minors, fugitives or persons who were not permitted to exit French territory. See 'Terrorisme: qu'est-ce que la fiche «S»?' (Le Monde, 31 August 2015, https://www.lemonde.fr /les-decodeurs/article/2015/08/31/terrorisme-peut-on-sanctionner -les-personnes-faisant-l-objet-d-une-fiche-s_4741574_4355770 .html).

${ }^{59}$ See 'Valls: "20.000 personnes font l'objet d'une fiche S en France" (Le Figaro, 24 November 2015, https://www.lefigaro.fr/flash-actu /2015/11/24/97001-20151124FILWWW00383-valls-20000-fiches-s .php).

${ }^{60}$ The lawyer works on the cases of Kurds who have been prosecuted on terrorism charges. This information is based on two presentations the lawyer gave at the National Assembly in 2015 and 2016.

${ }^{61}$ 'Votre loyalisme vis-à-vis de nos institutions et de notre pays nest pas garanti. Translation by the author.

${ }^{62}$ See 'Dix Kurdes condamnés à Paris pour financement du PKK' (Le Monde, 21 January 2015, https://www.lemonde.fr/societe/article /2015/01/28/dix-kurdes-condamnes-a-paris-pour-financement-du -pkk_4565253_3224.html). 
63 'Cétait aussi une procédure inquiétante où la police française a relayé en France la répression politique des services turcs.' Translation by the author.

${ }^{64}$ See 'Annulation d'une enquête antiterroriste contre un Kurde qui criait au complot' (Le Point, 27 February 2014, https://www.lepoint.fr /societe/annulation-d-une-enquete-antiterroriste-contre-un-kurde -qui-criait-au-complot-page-2-27-02-2014-1796311_23.php\#).

${ }^{65}$ See 'Eutelsat accusé de bloquer des télévisions kurdes' (Le Monde, 12 November 2016, https://www.lemonde.fr/economie/article/2016 /11/12/eutelsat-accuse-de-bloquer-des-televisions-kurdes _5030059_3234.html).

${ }^{66}$ The civil war between the Turkish state and the PKK has lasted for three decades and resulted in 40,000 deaths. The peace negotiations that were undertaken by the two parties (although blocked in 2013) continued till the summer 2015, until the army imposed a military curfew on several Kurdish villages and cities.

${ }^{67}$ See David \& Toktamiş 2015; Marchand 2017; Gunter 2016; Baser \& Özturk 2017.

${ }^{68}$ See 'ISIS' Yazidi Genocide' (Foreign Affairs, June 8 2017, https://www .foreignaffairs.com/articles/syria/2017-06-08/isis-yazidi-genocide).

${ }^{69}$ See 'Kurdish protesters break into European Parliament' $(B B C, 7$ October 2014, https://www.bbc.com/news/av/world-europe-29517387 /kurdish-protesters-break-into-european-parliament).

${ }^{70}$ See "Welcome to Stalingrad. Welcome to Kobane": Inside the Syrian Town Under Siege by the Islamic State' (Vice, January 13 2015, https://www.vice.com/en_us/article/bjaq83/welcome-to-stalingrad -welcome-to-kobane-inside-the-syrian-town-under-siege-by-the -islamic-state).

${ }^{71}$ See 'Hollande-PYD meeting challenges Erdogan' (Al-Monitor, 12 February 2015, https://www.al-monitor.com/pulse/originals/2015/02 /turkey-france-kurdish-guerillas-elysee.html).

${ }^{72}$ See 'Assassinat de militantes kurdes à Paris : la justice souligne l'implication des services secrets turcs' (Le Monde, 23 July 2015, http:// www.lemonde.fr/police-justice/article/2015/07/23/assassinat-de -militantes-kurdes-a-paris-la-justice-pointe-l-implication-des-services -secrets-turcs_4694801_1653578.html).

${ }^{73}$ See 'Suspect in murders of Kurdish activists dies in Paris hospital' (France24, 17 December 2016, http://www.france24.com/en/2016 1217-france-kurdish-assassination-suspect-dies-paris-hospital).

74 'Cette agression a eu lieu au moment où les discussions en cours pour trouver une solution au problème kurde en Turquie sont d'actualité ... 
L'Etat français a sa part de responsabilité. Si les auteurs de ces délits ne sont pas retrouvés, la France sera considérée indiscutablement comme complice.' Translation by the author. See 'Kurdes et Turcs font pression sur Paris après les meurtres de trois militantes kurdes' (Le Monde, 12 January 2013, https://www.lemonde.fr/societe/article /2013/01/12/manifestation-a-paris-apres-les-meurtres-des-trois -militantes-kurdes_1816225_3224.html).

${ }^{75}$ See Information and Liason Bulletin, no 334, January 2013 (Kurdish Institute of Paris), https://www.institutkurde.org/en/publications /bulletins/list.php.

${ }^{76}$ The Kobane siege is also referenced as a 'transformative event' by Ciordia (2018) in the recent development of the Kurdish conflict in Turkey and in how collective action frames are employed by the Kurdish movement.

77 The role played by the subsequent generations is potentially one reason for this and will be discussed further in the following chapter.

${ }^{78}$ See 'Kurds across Europe hold protests calling for more help for Kobani' (Euronews, 8 October 2014, https://www.dailymotion.com /video/x27hn8i).

${ }^{79}$ As discussed later, calls for the removal of the PKK from the list of terrorist organisations were also fuelled by the political ambivalence stemming from the partial recognition of the Syrian Kurdish forces (PYD) as a liable partner in the combat against ISIS and simultaneously of the listing of the PKK, very close to the PYD in terms of ideology and contacts, as a terrorist organisation.

${ }^{80}$ The AKP is the Justice and Development Party, a conservative party led by Recep Tayyip Erdoğan. The HDP is the People's Democratic Party, a pro-minority and left-wing party that was led by the currently jailed Selahattin Demirtaş.

${ }^{81}$ See 'KCD-E: We must use the remaining voting time well' (ANF News, 25 May 2015, https://anfenglish.com/news/kcd-e-we-must-use-the -remaining-voting-time-well-11383).

${ }^{82}$ Table is compiled by the author and based on statistics provided at https://secim.haberler.com/2015/finlandiya-secim-sonuclari.

${ }^{83}$ The Kemalist Republican People's Party, CHP, received 21.4\% (20.9\%) of votes in London, while its voter turnout remained less in other countries. Overall, although its share among diaspora votes was less, it received a quarter of all votes: $25.32 \%$ (24.95\%).

${ }^{84}$ See 'La Mairie de Paris organise Newroz pour les Kurdes' (Gouvernement régional du Kurdistan, Représentation en France, 2016, 
https://www.france.gov.krd/info/la-mairie-de-paris-organise-newroz -pour-les-kurdes-313.html).

${ }^{85}$ President Hollande also had close contacts with Iraqi Kurdish leaders. He visited Iraq, first Baghdad and then Erbil, on 12 September 2014, and described the visit to Iraqi Kurdistan as 'very moving' because of 'the friendship between the French and Kurdish peoples'. Massoud Barzani also visited Paris in February 2015, where he met Hollande two days after he had met with the representatives of Syrian Kurdistan. See Bulletin of Liaison and Information, September 2014, no354, p. 4: https://www.institutkurde.org/en/publications /bulletins/list.php. See also 'Massoud Barzani à Paris pour plaider la cause des Kurdes' (La Croix, 10 February 2015, https://www.la-croix .com/Actualite/Monde/Massoud-Barzani-a-Paris-pour-plaider-la -cause-des-Kurdes-2015-02-10-1278955).

${ }^{86}$ See 'Hollande-PYD meeting challenges Erdogan' (Al-Monitor, 12 February 2015, https://www.al-monitor.com/pulse/originals/2015 /02/turkey-france-kurdish-guerillas-elysee.html).

${ }^{87}$ The name of the city removed for purposes of anonymity.

88 'Le crime politique reconnu doit obtenir vérité sur les commanditaires et Justice.' Translation by the author.

${ }^{89}$ See Janroj Yilmaz Keles 'The European Kurds Rallying to Fight IS' (Open Democracy, 10 December 2014, https://www.opendemocracy .net/opensecurity/janroj-yilmaz-keles/european-kurds-rallying -to-fight-is). See also 'Diaspora Kurds Return to Homeland to Battle ISIL Jihadists' (Hurrieyt Daily News, 8 October 2014, http:// www.hurriyetdailynews.com/diaspora-kurds-return-to-homeland -to-battle-isil-jihadists.aspx?pageID=238\&nid=72724).

${ }^{90}$ See the exhibition website (in French) at https://www.institutkurde .org/activites_culturelles/evenement_425.html.

91 'Dès lors, nous dédions la quatrième édition du festival aux trois militantes Kurdes assassinées, à ceux qui ont fait et font encore la révolution de Rojava, ainsi qu'aux femmes Kurdes.' Translation by the author.

${ }^{2}$ See the festival programme (in French) at https://www.yumpu.com /en/document/read/54463103/festival-cinema-kurde-2015-web.

${ }^{93}$ See the Migrant Integration Policy Index report for France at http:// www.mipex.eu/france.

${ }^{94}$ See 'Hollande-PYD meeting challenges Erdogan' (Al-Monitor, 12 February 2015, https://www.al-monitor.com/pulse/originals/2015 /02/turkey-france-kurdish-guerillas-elysee.html). 
${ }^{95}$ Currently, the YPG troops include an estimated number of 30,00035,000 combatants, of whom approximately $20-40 \%$ belong to the female battalion, the YPJ (see http://www.globalsecurity.org/military /world/para/ypg.htm).

96 These remarks are based on Nessrin Abdullah's speech given in January 2016 in Paris.

${ }^{97}$ In practice, the legal measures taken against active members in the PKK vary considerably between different European countries, as discussed earlier.

${ }^{98}$ See 'Manuel Valls : «Oui, la France est en guerre contre le terrorisme »' (Le Monde, 13 January, 2015, https://www.lemonde.fr/politique/article /2015/01/13/manuel-valls-oui-la-france-est-en-guerre-contre-le -terrorisme_4555301_823448.html).

99 This system of filing (FPR, Le fichier des personnes recherchées) was created in 1969 to facilitate the investigation of various individuals, such as lost minors, the escaped or individuals forbidden to exit French territory. See 'Fiches S, FPR, et FSPRT, plongée dans les fichiers de l'antiterrorisme (France Culture, 26 March 2018, https://www .franceculture.fr/droit-justice/fiches-s-fpret-fsprt-plongee-dans-les -fichiers-de-l-antiterrorisme).

${ }^{100}$ Fiche $S$ refers to a registry of security used by law enforcement to flag an individual who is considered to be a threat to national security (S comes from sûrété de létat - state security). In 2015, the estimated number of individuals with such a marking was 20,000. Two years later, in 2017, the number of individuals having $S$ fiche was 25,000, of whom 9,700 were suspected of radicalisation. See: 'Sortie de létat d'urgence : Un bilan et des chiffres clés' (Ministère de l'Intérieur, 2 November 2017, https://www.interieur.gouv.fr/Espace-presse/Dossiers -de-presse/Sortie-de-l-etat-d-urgence-un-bilan-et-des-chiffres -cles).

${ }^{101}$ See 'Valls: « 20.000 personnes font l'objet d'une fiche S en France »' (Le Figaro, 24 November 2015, https://www.lefigaro.fr/flash-actu /2015/11/24/97001-20151124FILWWW00383-valls-20000-fiches-s .php).

102 The lawyer works on the cases of Kurdish individuals who have been the object of legal procedures. These numbers are based on two presentations that the lawyer gave at the National Assembly in 2015 and 2016.

${ }^{103}$ See 'Jugement attendu pour une filière française du PKK' (Le Monde, 1 November 2011, https://www.lemonde.fr/europe/article 
/2011/11/01/jugement-attendu-pour-une-filiere-francaise-du-pkk _1596771_3214.html).

${ }^{104}$ See 'Tourments au "Petit Kurdistan"' (Le Monde, 12 February 2013, https://www.lemonde.fr/international/article/2013/02/12/tour ments-au-petit-kurdistan_1830894_3210.html).

${ }^{105}$ See 'Vague d'arrestation dans les milieux kurdes en région parisienne' (Le Monde, 5 February 2007, https://www.lemonde.fr/societe /article/2007/02/05/vague-d-arrestation-dans-les-milieux-kurdes -en-region-parisienne_863529_3224.html).

106 See 'La Turquie et la France signent un vaste accord sécuritaire' (Le Point, 7 October 2011, https://www.lepoint.fr/monde/la-turquie -et-la-france-signent-un-vaste-accord-securitaire-07-10-2011 -1381945_24.php\#).

${ }^{107}$ See 'Annulation d'une enquête antiterroriste contre un Kurde qui criait au complot' (20 Minutes, 27 February 2014, https://www.20minutes .fr/societe/1310794-20140227-20140227-annulation-enquete-anti terroriste-contre-kurde-criait-complot).

${ }^{108}$ See 'Dix Kurdes condamnés à Paris pour financement du PKK' (Le Monde, 28 January 2015, https://www.lemonde.fr/societe/article /2015/01/28/dix-kurdes-condamnes-a-paris-pour-financement-du -pkk_4565253_3224.html).

109 See the 'Tribunal administratif de Nantes, 22 juin 2016, $\mathrm{n}^{\circ}$ 1408162' at https://www.doctrine.fr/d/TA/Nantes/2016/AC62D450DF4026D 98E2B2 and 'Peut-on se voir refuser la nationalité française pour ses positions politiques ?' (Agence Anadolu, 20 January 2020, https:// www.aa.com.tr/fr/monde/peut-on-se-voir-refuser-la-nationalit $\%$ C3\%A9-francaise-pour-ses-positions-politiques-/1708308).

110 'Mme A B épouse X demande l'annulation de la décision du 3 février 2015 par laquelle le ministre de l'intérieur a également rejeté sa demande de naturalisation au motif que le loyalisme de son époux vis$\grave{a}$-vis de la France et de ses institutions n'est pas garanti .... Translation by the author.

${ }^{111}$ See 'Projet de loi constitutionnelle Protection de la Nation' (Senat, https://www.senat.fr/rap/115-447/115-4476.html).

${ }^{112}$ See "La déchéance de nationalité ne facilite pas la lutte contre le terrorisme"' (Arte, 13 August 2016, https://info.arte.tv/fr/la-decheance -de-nationalite-ne-resoudra-pas-la-lutte-contre-le-terrorisme).

${ }^{113}$ See 'Denmark bans Kurdish TV station and fines it $£ 1.2 \mathrm{~m}$ ' (The Guardian, 25 July 2013, https://www.theguardian.com/media /greenslade/2013/jul/25/kurds-denmark). 
114 See 'Belgium: Belgian police raid Kurdish buildings and TV stations' (Reuters, 5 March 2010, https://reuters.screenocean.com/record /701187).

115 See 'Kurdish ROJ TV Sparks Debate' (DW, 10 December 2008, https://www.dw.com/en/kurdish-roj-tv-sparks-debate/a-3863144).

116 The YPG is affiliated with the Kurdistan Workers' Party (Partiya Karkerên Kurdistan, PKK), although this relationship is often contested since the latter features on the EU's and United States' lists of terrorist organisations. See 'Turkey v Syria's Kurds v Islamic State' (BBC, 19 February 2016, http://www.bbc.com/news/world-middle -east-33690060).

117 See 'Asya Abdullah: «Les femmes kurdes ne se soumettront jamais à Daech»' (Le Figaro, 12 February 2015, http://www.lefigaro.fr/international/2015/02/12/01003-20150212ARTFIG00392-asya-abdullah -les-femmes-kurdes-ne-se-soumettront-jamais-a-daech.php).

${ }^{118}$ See 'Ces revenants du Rojava qui inquiètent les services de renseignement' (Mediapart, 1 September 2019, https://www.mediapart.fr /journal/international/010919/ces-revenants-du-rojava-qui-inquie tent-les-services-de-renseignement?onglet=full).

${ }^{119}$ See 'Father of British YPG volunteer in Syria arrested over terrorism offences' (The Guardian, 27 December 2019, https://www.theguardian .com/uk-news/2019/dec/27/father-of-british-ypg-volunteer-in-syria -arrested-terrorism-offences).

${ }^{120}$ See 'Ces volontaires français combattent Daech en Syrie mais pour la Turquie, ce sont des terroristes' (Slate, 2 November 2017, http:// www.slate.fr/story/153158/ces-volontaires-francais-combattent -daech-en-syrie-mais-pour-la-turquie-ce-sont-des).

${ }^{121}$ See 'François Hollande vientréconforterla communautéjuiveàla synagogue dela Victoire' (Le Journal du Dimanche, 11 January 2015, https:// www.lejdd.fr/Societe/Religion/A-la-synagogue-de-la-Victoire -Francois-Hollande-et-Manuel-Valls-viennent-reconforter-la-com munaute-juive-712020).

122 Between 40,000 and 50,000 Yezidi Kurds fled the troops of ISIS to Sinjar mountain in August 2014, after ISIS had massacred approximately 4,000 Yezidi men. A combination of international troops, the YPG and PKK troops managed to open a corridor from the mountain to the Iraqi Kurdistan region.

${ }^{123}$ Kobane Calling was also the name of the comic illustrated book written and designed by an Italian author, Zerocalcare. The book tells of the author's journey to the Turkish-Syrian border near Kobane, in 2014. 
${ }^{124}$ See the Kurdish-European Society website at https://www.kurdish european.eu/index.php.

125 By 'international', I refer here to influential news outlets of print and visual media that 'act as a meaning-making and opinion-moulding venue for mainly western societies', to quote Kardaş and Yesiltaş (2017).

126 'Rehana, the Kurdish Female Fighter Who "Killed" 100 Isis Fighters, Spotted in Kobane' (International Business Times, 8 June 2015, http:// www.ibtimes.co.in/rehana-kurdish-female-fighter-who-killed-100 -isis-fighters-spotted-kobane-photo-635123).

127 See '\#BBCtrending: Who Is the "Angel of Kobane"?' (BBC, 3 November 2014, http://www.bbc.com/news/blogs-trending-29853513).

128 See 'These Remarkable Women Are Fighting ISIS - It's Time You Know Who They Are' (Marie Claire, October 1, 2014, https://www.marie claire.com/culture/news/a6643/these-are-the-women-battling-isis).

129 See 'The Kurdish Stalingrad' (The Economist, 1 November 2014, https://www.economist.com/middle-east-and-africa/2014/11/01 /the-kurdish-stalingrad).

130 Also, The Economist titled one of its articles on Kobane 'The Kurdish Stalingrad' (1 November 2014, http://www.economist.com/news /middle-east-and-africa/21629475-kobane-has-acquired-huge -symbolic-significance-all-those-fighting-it).

131 See 'Kobané, ville martyre' (Arte, 10 July 2015, https://info.arte.tv/fr /kobane-ville-martyre).

132 I will use both terms, transnational field and transnational space, interchangeably.

133 The current study did not inquire into first-generation members' lived experiences, so this section is based on how the second-generation members reflected on this issue.

134 Mahdod (2016: 6) briefly discusses diasporic consciousness in her book Kurdish Diaspora Online: From Imagined Communities to Managing Communities.

135 The interviewee refers to the military clashes that took place between the Turkish military and the PKK in 2009.

136 The significance of global and cyber spaces to changing political landscapes and subjectivities needs further attention than unfortunately is possible to grant it within the constraints of this book.

137 For some exceptions, see Baser 2014, 2015a; Baser \& Swain 2011; Østergaard-Nielsen 2001, 2003. 



\section{Bibliography}

Adam, P. (2017). Identités et diaspora kurde en France (Master's thesis, Institut d'Etudes politiques de Lille, Lille).

Adamson, F. (2008, March). Constructing the diaspora: Diaspora identity politics and transnational social movements. Paper presented at the 49th Annual Meeting of the International Studies Association, San Francisco, CA.

Adamson, F. (2012). Constructing the diaspora: diaspora identity politics and transnational social movements. In T. Lyons \& P. Mandaville (Eds.), Politics from afar: transnational diasporas and networks (pp. 25-42). New York: Columbia University Press.

Adamson, F. (2013). Mechanisms of diaspora mobilization and the transnationalization of civil war. In J. T. Checkel (Ed.), Transnational dynamics of civil war (pp. 63-88). Cambridge, UK: Cambridge University Press. DOI: https://doi.org/10.1017/CBO9781139179089.006 Adamson, F. (2016). The growing importance of diaspora politics. Current History, 115(784), 291-297. DOI: https://doi.org/10.1525/curh .2016.115.784.291

Adamson, F. (2019). Sending states and the making of intra-diasporic politics: Turkey and its diaspora(s). International Migration Review, 53(1), 210-236. DOI: https://doi.org/10.1177/0197918318767665 
Akgönül, S. (2017). Turks as a minority: The effects of minority status on electoral behaviour. In B. Baser \& E. Özturk (Eds.), Authoritarian politics in Turkey. Elections, resistance and the AKP (pp. 121-140). London, New York: IB Tauris. DOI: https://doi.org/10.5040/978135 0985438.ch-007

Akkaya, A. H., \& Jongerden, J. (2011). The PKK in 2000s: Continuity through breaks? In M. Casier \& J. Jongerden (Eds.), Nationalisms and politics in Turkey: Political Islam, Kemalism and the Kurdish issue (pp. 143-162). London, New York: Routledge.

Akkaya, A. H., \& Jongerden, J. P. (2012). Reassembling the political: The PKK and the project of radical democracy. European Journal of Turkish Studies, 14, 1-20. DOI: https://doi.org/10.4000/ejts.4615

Akkaya, A. H., \& Jongerden, H. (2013). Confederalism and autonomy in Turkey: The Kurdistan Workers' Party and the reinvention of democracy. In C. Gunes \& W. Zeydanlioğlu (Eds.), The Kurdish question in Turkey. New perspectives on violence, representation and reconciliation (pp. 186-204). London: Routledge.

Alinejad, D. (2017). The Internet and formations of Iranian American-ness. Next generation diaspora. Cham: Palgrave Macmillan. DOI: https:// doi.org/10.1007/978-3-319-47626-1

Alinia, M. (2004). Spaces of diaspora. Kurdish identities, experiences of otherness and politics of belonging (Doctoral dissertation, Gothenburg University, Gothenburg).

Alinia, M., \& Eliassi, B. (2014). Temporal and generational impact on identity, home(land) and politics of belonging among the Kurdish diaspora. Nordic Journal of Migration Research, 4(2), 73-81. DOI: https://doi.org/10.2478/njmr-2014-0008

Allsopp, H. (2015). The Kurds of Syria: Political parties and identity in the Middle East. London, New York: IB Tauris.

Andén-Papadopoulos, K., \& Pantti, M. (2013). The media work of Syrian diaspora activists: Brokering between the protest and mainstream media. International Journal of Communication, 7, 2185-2206.

Anderson, B. (1991). Imagined communities. Reflections on the origin and spread of nationalism. London: Verso.

Anthias, F. (1998). Evaluating 'diaspora': Beyond ethnicity? Sociology, 32(3), 557-580. DOI: https://doi.org/10.1177/0038038598032003009 Anthias, F. (2009 September). Methodological nationalism versus methodological transnationalism: moving beyond the binary. Paper presented at 6th Annual IMISCOE Conference, Stockholm, Sweden. 
Anthias, F. (2012). Transnational mobilities, migration research and intersectionality. Nordic Journal of Migration Research, 2(2), 102-110. DOI: https://doi.org/10.2478/v10202-011-0032-y

Argun, B. E. (2003). Turkey in Germany: The Transnational Sphere of Deutschkei. New York: Routledge. DOI: https://doi.org/10.4324 19780203952696

Asad, T. (2006). Trying to understand French secularism. In H. de Vries \& L. Sullivan (Eds.), Political theologies: Public religions in a post-secular world (pp. 494-526). New York: Fordham University Press. DOI: https://doi.org/10.5422/fso/9780823226443.003 .0026

Ata, A. (2017). Transnational migration, integration and identity: A study of Kurdish diaspora in London (Doctoral dissertation, London South Bank University, London).

Ayyildiz, E. (2007). Talkootöistä kansalaistottelemattomuuteen. In A. Leinonen, T. Kojo, M. Nousiainen, S. Peltonen, \& L. Tainio (Eds.), Turkki - Euroopan Rajalla? (pp. 319-336). Helsinki: Gaudeamus.

Ayata, B. (2011). Kurdish transnational politics and Turkey's changing Kurdish policy: The journey of Kurdish broadcasting from Europe to Turkey. Journal of Contemporary European Studies, 19(4), 523-533. DOI: https://doi.org/10.1080/14782804.2011.639988

Aziz, M. (2011). The Kurds of Iraq. Ethnonationalism and national identity in Iraqi Kurdistan. London: IB Tauris \& Co Ltd. DOI: https://doi .org/10.5040/9780755692835

Bailey, O., Georgiou, M., \& Harindranath, R. (2007). Transnational lives and the media. Re-imagining diasporas. Basingstoke: Palgrave Macmillan. DOI: https://doi.org/10.1057/9780230591905

Barkey, H. J., \& Fuller, G. E. (1998). Turkey's Kurdish question. Lanham, MD: Rowman \& Littlefield.

Baser, B. (2011). Kurdish diaspora activism in Europe with a particular focus on Great Britain. Berlin: Berghof Peace Support, Centre for Just Peace and Democracy.

Baser, B. (2012). Inherited conflicts: spaces of contention between secondgeneration Turkish and Kurdish diasporas in Sweden and Germany (Doctoral dissertation, European University Institute, Firenze).

Baser, B. (2014). The awakening of a latent diaspora: The political mobilization of first and second generation Turkish migrants in Sweden. Ethnopolitics, 13(4), 355-376.DOI:https://doi.org/10.1080/17449057 .2014 .894175 
Baser, B. (2015a). Diasporas and homeland conflicts. A comparative perspective. Farnham: Ashgate Publishing Limited. DOI: https://doi .org/10.4324/9781315577012

Baser, B. (2015b). Gezi spirit in transnational space. In I. David \& K. Toktamiş (Eds.), Everywhere Taksim: Politics in contemporary Turkey (pp. 251-265). Amsterdam: Amsterdam University Press.

Baser, B. (2015c). Komkar: the unheard voice in the Kurdish Diaspora. In A. Christou \& E. Mavroudi (Eds.), Dismantling diasporas: Rethinking the geographies of diasporic identity, connection and development (pp. 113-128). Farnham: Ashgate. DOI: https://doi .org/10.4324/9781315577586

Baser, B. (2016). Kurdistan and Kurdish politics. Oxford Bibliographies. International relations. DOI: https://doi.org/10.1093/obo /9780199743292-0131

Baser, B. (2017). Tailoring strategies according to ever-changing dynamics: The evolving image of the Kurdish diaspora in Germany. Terrorism and Political Violence, 29(4), 674-691. DOI: https://doi.org/10.1080 /09546553.2015.1060226

Baser, B. (2019). Kurdish diaspora activism in Europe: A closer look at the enablers and disablers of diaspora mobilization. In K. Engin (Ed.), Kurdische Migrant_innen in Deutschland: Lebenswelten-Identität-Politische Partizipation (pp. 179-198). Kassel: Kassel University Press. DOI: https://doi.org/10.19211/KUP9783737606493

Baser, B., Ahmedi, I., \& Toivanen, M. (2017). The transnational activism of the Kurdish Diaspora and the Swedish approach to the Kurdish Question. In B. Baser \& P. T. Levin (Eds.), Migration from Turkey to Sweden: Integration, belonging and transnational Community (pp. 228-260). London: IB Tauris. DOI: https://doi.org /10.5040/9781350987180.ch-008

Baser, B., Emanuelsson, A.-C., \& Toivanen, M. (2015). (In)visible spaces and tactics of transnational engagement: A multi-dimensional approach to the Kurdish diaspora. Kurdish Studies Journal, 3(2), 128-150. DOI: https://doi.org/10.33182/ks.v3i2.411

Baser, B., \& Halperin, A. (2019). Diasporas from the Middle East: Displacement, transnational identities and homeland politics. British Journal of Middle Eastern Studies, 46(2), 215-221. DOI: https://doi .org/10.1080/13530194.2019.1569308

Baser, B., \& Swain, A. (2011). Stateless diaspora groups and their repertoires of nationalist activism in host countries. Journal of International Relations, 8(1), 37-60. 
Baser, B., \& Toivanen, M. (2017). The politics of genocide recognition: Kurdish nation-building and commemoration in the post-Saddam Era. Journal of Genocide Research, 19(3), 404-426. DOI: https://doi .org/10.1080/14623528.2017.133864

Baser, B., \& Toivanen, M. (2018a). Diasporas building peace: Reflections from the Middle Eastern diasporas. In R. Cohen \& C. Fischer (Eds.), Routledge Handbook of Diaspora Studies (pp. 345-353). Abingdon: Routledge.

Baser, B., \& Toivanen, M. (2018b). Politicized and depoliticized ethnicities, power relations and temporality: Insights to outsider research from comparative and transnational fieldwork. Ethnic and Racial Studies, 41(11), 2067-2084. DOI: https://doi.org/10.1080/01419870.2017.1348530

Baser, B., \& Özturk, E. (2017). Authoritarian politics in Turkey. Elections, resistance and the AKP. London, New York: IB Tauris. DOI: https:// doi.org/10.5040/9781350985438

Bauböck, R. \& Faist, T. (Eds.) (2010). Diaspora and transnationalism. Concepts, theories and methods. Amsterdam: Amsterdam University Press. DOI: https://doi.org/10.5117/9789089642387

Beauchemin C., Hamel, C., \& Simon P. (Eds.). (2010). Trajectories and origins. Survey on population diversity in France. Initial findings (Document de travail 168). Paris: INED.

Beaugrand, C., \& Geisser, V. (2016). Social mobilization and political participation in the diaspora during the 'Arab Spring. Journal of Immigrant \& Refugee Studies, 14(3), 239-243. DOI: https://doi.org /10.1080/15562948.2016.1212133

Bengio, O. (2012). The Kurds of Iraq: Building a state within a state. London: Lynne Rienner. DOI: https://doi.org/10.1017/rms.2015.56

Bengio, O. (2005). Autonomy in Kurdistan in historical perspective. In B. O'Leary, J. McGarry, \& K. Salih (Eds.), The future of Kurdistan in Iraq (pp. 173-185). Pennsylvania, PA: University of Pennsylvania Press. DOI: https://doi.org/10.1093/publius/pjj001

Bennett, W. L. (2008). Changing citizenship in the digital age. In K. Montgomery, J. Earl, K. A. Foot, \& M. Xenos (Eds.), Civic life online: Learning how digital media can engage youth (pp. 1-24). Cambridge, MA: The MIT Press. DOI: https://doi.org/10.1162/dmal .9780262524827 .001

Berrington, A. (2020). Expectations for family transitions in young adulthood among the UK second generation. Journal of Ethnic and Migration Studies, 46(5), 913-935. DOI: https://doi.org/10.1080/136 9183X.2018.1539276 
Beyene, H. G. (2015). Are African diasporas development partners, peace-makers or spoilers? The case of Ethiopia, Kenya and Nigeria. Diaspora Studies, 8(2), 145-161. DOI: https://doi.org/10.1080/0973 9572.2015.1029714

Bommes, M., \& Thränhardt, D. (2010). National paradigms of migration research. Osnabrück: Institut für Migrationsforschung und Interkulturelle Studien.

Boon-Kuo L., Hayes B., Sentas V., \& Sullivan, G. (2015). The entrapment and prosecution of Adem Uzun. In L. Boon-Kuo, B. Hayes, V. Sentas, \& G. Sullivan (Eds.), Building peace in permanent war. Terrorist listing and conflict transformation (pp. 127-129). London: International State Crime Initiative.

Bozarslan, H. (2004). Violence in the Middle East: From political struggle to self-sacrifice. Princeton, NJ: Marcus Wiener.

Brickell, K. \& Datta, A. (Eds.) (2011). Translocal geographies. Spaces, places, connections. Ashgate e-book. DOI: https://doi.org/10.4324 /9781315549910

Brinkerhoff, J. (2009). Digital diasporas. Identity and transnational engagement. New York: Cambridge University Press.

Brubaker, R. (1992). Citizenship and nationhood in France and Germany. Cambridge, MA: Harvard University Press.

Brubaker, R. (2001). The return of assimilation? Changing perspectives on immigration and its sequels in France, Germany and the United States. Ethnic and Racial Studies, 24(4), 531-548. DOI: https://doi .org/10.1080/01419870120049770

Brubaker, R. (2002). Ethnicity without groups. European Journal of Sociology, 43(2), 163-189. DOI: https://doi.org/10.1017/S00039756 02001066

Brubaker, R. (2005). The 'diaspora' diaspora. Ethnic and Racial Studies, 28(1), 1-19. DOI: https://doi.org/10.1080/0141987042000289997

Buffon, V., \& Allison, C. (2016). The gendering of victimhood: Western media and the Sinjar genocide. Kurdish Studies, 4(2), 176-196. DOI: https://doi.org/10.33182/ks.v4i2.427

Buzan, B., Wæver, O., \& de Wilde, J. (1998). Security: A new framework for analysis. Boulder, CO: Lynne Rienner.

Candidatu, L., Leurs, K., \& Ponzanesi, S. (2019). Digital diasporas: Beyond the buzzword. Towards a relational understanding of mobility and connectivity. In R. Tsagarousianou \& Je. Retis (Eds.), The handbook of diasporas, media and culture (pp. 33-47). Oxford: Wiley Blackwell. 
Cano, G., \& Delano, A. (2007). The Mexican government and organised Mexican immigrants in the United States: A historical analysis of political transnationalism (1848-2005). Journal of Ethnic and Migration Studies, 33(5), 695-725. DOI: https://doi.org/10.1080 /13691830701359157

Casier, M. (2010). Designated terrorists: The Kurdistan Workers' Party and its struggle to (re)gain political legitimacy. Mediterranean Politics, 15(3), 393-413. DOI: https://doi.org/10.1080/13629395.2010.517105

Casier, M. (2011). The politics of solidarity: The Kurdish question in European Parliament. In M. Casier \& J. Jongerden (Eds.), Nationalisms and political Islam in Turkey: Political Islam, Kemalism and the Kurdish issue (pp. 197-217). Abingdon: Routledge. DOI: https://doi .org/10.4324/9780203327036

Casier, M., \& Jongerden, J. P. (2012). Understanding today's Kurdish movement: Leftist heritage, martyrdom, democracy and gender. European Journal of Turkish Studies, 14. DOI: https://doi.org/10.4000/ejts.4656

Castles, S., de Haas, H., \& Miller, M. (2014). The age of migration. International population movements in the modern world. Basingstoke: Palgrave Macmillan.

Chaliand, G. (1994). The Kurdish tragedy. London, New York: Zed Books.

Chaudhary, A. R., \& Moss, D. M. (2016). Triadic political opportunity structures: Re-conceptualising immigrant transnational politics (IMI Working Paper Series, 129).

Chimienti, M., Block, A., Ossipow, L., \& Wihtol de Wenden, C. (2019). Second generation from refugee backgrounds in Europe. Comparative Migration Studies, 7(40), 1-15. DOI: https://doi.org/10.1186/s40878 -019-0138-2

Çiçek, C. (2017). The Kurds of Turkey. National, religious and economic identities. London, New York: IB Tauris. DOI: https://doi.org/10.5040 19781350988859

Ciordia, A. (2018). The effects of Kobane in the reconfiguration of the popular geopolitical codes of Turkey's Kurdish movement. Turkish Studies, 19(5),773-798. DOI: https://doi.org/10.1080/14683849.2018 .1484288

Cohen, R. (2008). Global diasporas: An introduction. London, New York: Routledge. DOI: https://doi.org/10.4324/9780203928943

Cohen, R. \& Fischer, C. (Eds.) (2019). Routledge handbook of diaspora studies. London, New York: Routledge. DOI: https://doi.org/10.4324 19781315209050 
Colasanti, N., Frondizi, R., Liddle, J., \& Meneguzzo, M. (2018). Grassroots democracy and local government in northern Syria: The case of democratic confederalism. Local Government Studies, 44(6), 807825. DOI: https://doi.org/10.1080/03003930.2018.1501366

Costa, E., \& Alinejad, D. (2020). Experiencing homeland: Social media and transnational communication among Kurdish migrants in Northern Italy. Global perspectives, 1(1), 1-12. DOI: https://doi.org /10.1525/gp.2020.12783

Cressey, G. (2006). Diaspora youth and ancestral homeland: British Pakistani/Kashmiri youth visiting kin in Pakistan and Kashmir. Leiden: Brill.

Crul, M., Schneider, J., \& Leslie, F. (2010). The European second generation compared. Does the integration context matter? Amsterdam: Amsterdam University Press. DOI: https://doi.org/10.1515/9789048516926

Crul, M., \& Vermeulen, H. (2003). The second generation in Europe. International Migration Review, 37(4), 965-986. DOI: https://doi .org/10.1111/j.1747-7379.2003.tb00166.x

Dahinden, J. (2009). Are we all transnationals now? Network transnationalism and transnational subjectivity: The differing impacts of globalization on the inhabitants of a small Swiss city. Ethnic and Racial Studies, 32(8), 1365-1368. DOI: https://doi.org/10.1080 /01419870802506534

Dahinden, J. (2012). Transnational belonging, non-ethnic-forms of identification, and diverse mobilities: Rethinking migrant integration? In M. Messer, R. Schroeder, \& R. Wodak (Eds.), Migrations: interdisciplinary perspectives (pp. 117-128). Vienna: Springer. DOI: https://doi.org/10.1007/978-3-7091-0950-2_11

Dahinden, J. (2016). A plea for the 'de-migranticization' of research on migration and integration. Ethnic and Racial Studies, 39(13), 22072225. DOI: https://doi.org/10.1080/01419870.2015.1124129

Dahinden, J. (2017). Transnationalism reloaded: The historical trajectory of a concept. Ethnic and Racial Studies, 40(9), 1474-1485. DOI: https://doi.org/10.1080/01419870.2017.1300298

Dalton, R. J. (2017). The participation gap: Social status and political inequality. Oxford: Oxford University Press. DOI: https://doi.org /10.1093/oso/9780198733607.001.0001

David, I., \& Toktamiş, K. F. (2015). Everywhere Taksim. Sowing the seeds for a New Turkey at Gezi. Amsterdam: Amsterdam University Press. DOI: https://doi.org/10.5117/9789089648075 
de Goede, M. (2008). The politics of pre-emption and the war on terror in Europe. European Journal of International Relations, 14(1), 161185. DOI: https://doi.org/10.1177/1354066107087764

de Haas, H., \& Rodríguez, F. (2010). Mobility and human development: Introduction. Journal of Human Development and Capabilities, 11(2), 177-184. DOI: https://doi.org/10.1080/19452821003696798

della Porta, D. (2008). Eventful protest, global conflicts. Distinktion: Journal of Social Theory, 9(2), 27-56. DOI: https://doi.org/10.1080 /1600910X.2008.9672963

della Porta, D., \& Diani, M. (2006). Social movements: An introduction. Oxford: Blackwell.

della Porta, D., \& Tarrow, S. (2005). Transnational processes and social activism: an introduction. In D. Della Porta \& S. Tarrow (Eds.), Transnational protest and global activism (pp. 1-17). Lanham, MD: Rowman \& Littlefield.

Demir, I. (2015). Battlespace diaspora: How the Kurds of Turkey revive, construct and translate the Kurdish struggle in London. In A. Christou \& E. Mavroudi (Eds.), Dismantling diasporas: Rethinking the geographies of diasporic identity, connection and development (pp. 71-85). London: Ashgate. DOI: https://doi.org/10.4324/9781315577586

Demmers, J. (2002). Diaspora and conflict: Locality, long-distance nationalism, and delocalisation of conflict dynamics. The Public, 9(1), 85-96. DOI: https://doi.org/10.1080/13183222.2002.11008795

Dinc, P. (2020). The Kurdish movement and the Democratic Federation of Northern Syria: An alternative to the (nation-)state model? Journal of Balkan \& Near Eastern Studies, 22(1), 47-67. DOI: https://doi .org/10.1080/19448953.2020.1715669

Dryaz, M. (2015). De la résistance microscopique à laction collective organisée: Engagement et désengagement des militants dans l'espace kurde (Doctoral dissertation, EHESS, Paris).

Eccarius-Kelly, V. (2008). Interpreting the PKK's signals in Europe. Perspectives on Terrorism, 11(11), 10-14.

Eccarius-Kelly, V. (2017). Modern Turkey: Opportunities and challenges. The Kurdish diaspora and Europe's gatekeeping after Kobane. The Copernicus Journal of Political Studies, 1, 39-53. DOI: https:// doi.org/10.12775/CJPS.2017.003

Eliassi, B. (2010). Stranger in my homeland: The politics of belonging among young people with Kurdish backgrounds in Sweden (Doctoral dissertation, Mid Sweden University, Östersund). 
Emanuelsson, A.-C. (2005). Diaspora global politics. Kurdish transnational networks and accommodation of nationalism (Doctoral dissertation, Gothenburg University, Gothenburg).

Emanuelsson, A.-C. (2008). 'Shall we return, stay or circulate?' Political changes in Kurdistan and transnational dynamics in Kurdish refugee families in Sweden. Journal of Migration and Refugee Issues, 4(3), 134-152.

Ergil, D. (2007). Kurdit ja valtio. In A. Leinonen, T. Kojo, M. Nousiainen, S. Peltonen, \& L. Tainio (Eds.), Turkki. Euroopan rajalla? (pp. 264-296). Helsinki: Gaudeamus.

Escafré-Dublet, A. (2014). Mainstreaming immigrant integration policy in France. Education, employment, and social cohesion initiatives. Brussels: Migration Policy Institute.

European Commission. (2006). The cultural situation of Kurds. Report. Committee on Culture, Science and Education. Retrieved 9 March 2021, from https://assembly.coe.int/nw/xml/XRef/Xref-XML2HTML -en.asp?fileid $=17477 \&$ lang=en

EUYOUPART. (2005a). Political participation of young people in Europe - Development of indicators for comparative research in the European Union. Retrieved 9 March 2021, from https://www.sora .at/en/topics/political-culture/euyoupart-2003-2005/en-ergebnisse .html

EUYOUPART. (2005b). Political participation of young people in Europe - Development of indicators for comparative research in the European Union. (WP8/D15 - Working Paper on National Survey Results National Report: France). Retrieved 9 March 2021, from https://www.sora.at/fileadmin/images/content/Pages/euyoupart _nationalreport-france.pdf

Faist, T. (2008). Migrants as transnational development agents: An inquiry into the newest round of the migration-development nexus. Population Space and Place, 14, 21-42. DOI: https://doi.org/10.1002 /psp.471

Favre, P., \& Offerlé, M. (2002). Connaissances politiques, compétence politique? Enquête sur les performances cognitives des étudiants français. Revue française de science politique, 52(2-3), 201-232.

Fiddian-Qasmiyeh, E. (2013). Transnational childhood and adolescence: Mobilizing Sahrawi identity and politics across time and space. Ethnic and Racial Studies, 36(5), 875-895. DOI: https://doi .org/10.1080/01419870.2011.631557 
Fokkema, T., Cela, E., \& Ambrosetti, E. (2013). Giving from the heart or from the ego? Motives behind remittances of the second generation in Europe. International Migration Review, 47(3), 539-572. DOI: https://doi.org/10.1111/imre.12032

Freedman, J. (2004). Secularism as a barrier to integration? The French dilemma. International Migration, 42(3), 5-27. DOI: https://doi.org /10.1111/j.0020-7985.2004.00287.x

Freedomhouse. (2008). Turkey in transit. Democratization in Turkey. Budapest: Freedom House Europe.

Furlong, A., \& Cartmel, F. (2007). Young people and social change. New perspectives. New York: Open University Press.

Galip, Ö. (2015). Imagining Kurdistan: Identity, culture, and society. London, New York: IB Tauris.

Geddes, A. (2003). The politics of migration and integration in Europe. London: Sage. DOI: https://doi.org/10.4135/9781446280492

Georgiou, M., \& Ponte, C. (2013). Introducing media, technology and the migrant family: Media uses, appropriations and articulations in a culturally diverse Europe. Observatorio, Special issue, Cost Action. DOI: https://doi.org/10.15847/obsOBS002013662

Giugni M. (2011). Political opportunity: still a useful concept?. In M. Hanagan \& C. Tilly (Eds.), Contention and Trust in Cities and States (pp. 271-283). Dordrecht: Springer. DOI: https://doi.org /10.1007/978-94-007-0756-6_19

Giugni, M., \& Passy, F. (2004). Migrant mobilization between political institutions and citizenship regimes: A comparison of France and Switzerland. European Journal of Political Research, 43(1), 51-82. DOI: https://doi.org/10.1111/j.1475-6765.2004.00145.x

Glick Schiller, N., Green Basch, L., \& Szanton-Blanc, C. (Eds.). (1992). Towards a transnational perspective on migration: Race, class, ethnicity, and nationalism reconsidered. New York: The New York Academy of Sciences.

Gourlay, W. (2018). Kurdayetî: Pan-Kurdish solidarity and cross-border links in times of war and trauma. Middle East Critique 27(1), 25-42. DOI: https://doi.org/10.1080/19436149.2017.1411110

Graziano, T. (2012). The Tunisian diaspora: Between 'digital riots' and Web activism. Social Science Information, 51(4), 534-550. DOI: https://doi.org/10.1177/0539018412456773

Grojean, O. (2008). La production de l'homme nouveau au sein de PKK. European Journal of Turkish Studies, 8, 1-23. 
Grojean, O. (2015). Politique d'exil: les mobilisations des Kurdes d'Europe. In J.-P. Chagnollaud (Ed.), Communautés en exil. Arméniens, Kurdes et Chrétiens d'Orient en territoires franciliens (pp. 53-68). Paris: L'Harmattan.

Grojean, O. (2019). Penser l'engagement et la violence des combattantes kurdes : des femmes en armes au sein dordres partisans singuliers. In C. Guibet Lafaye \& A. Frénod (Eds.), Sémanciper par les armes? Sur la violence politique des femmes (pp. 177-197). Paris: Inalco presses. DOI: https://doi.org/10.4000/books.pressesinalco.28788

Grojean, O., \& Massicard, E. (2005). Mobilisations transnationales et environnement politique. La dynamique des organisations kurdes et alévistes, entre Turquie et Europe. In M.-C. Blanc-Chaléard, S. Dufoix, \& P. Weil (Eds.), Létranger en questions (pp. 401-430). Paris: Le Manuscrit.

Gunes, C. (2017). The mobilisation of Kurds in Turkey during the 1980s and 1990s. In G. Stansfield \& M. Shareef (Eds.), The Kurdish question revisited (pp. 187-198). London: Hurst.

Gunes, C., \& Zeydanlioğlu, W. (Eds.). (2014). The Kurdish question in Turkey: New perspectives on violence, representation and reconciliation. London: Routledge. DOI: https://doi.org/10.4324/9780203796450

Gunter, M. (2007). The Kurds ascending: The evolving solution to the Kurdish problem in Iraq and Turkey. Basingstoke: Palgrave Macmillan. DOI: https://doi.org/10.1057/9780230338944

Gunter, M. (2009). From A to $Z$ of the Kurds. Lanham, MD: Scarecrow Press.

Gunter, M. (2011). Historical dictionary of the Kurds. Lanham, MD: Scarecrow Press.

Gunter, M. (2014). Out of nowhere. The Kurds of Syria in peace and war. London: Hurst \& Company.

Gunter, M. (2015). Iraq, Syria, ISIS and the Kurds: Geostrategic concerns for the U.S. and Turkey. Middle East Policy, 22(1), 102-111. DOI: https://doi.org/10.1111/mepo.12116

Gunter, M. (2016). The Kurds: A modern history. Princeton, NJ: Markus Wiener.

Harney, N. D., \& Baldassar, L. (2007). Tracking transnationalism: Migrancy and its futures. Journal of Ethnic and Migration Studies, 33(2), 189-198. DOI: https://doi.org/10.1080/13691830601154088

Hassanpour, A. (1998). Satellite footprints as national borders: MED-TV and the extraterritoriality of state sovereignty. Journal of Muslim Minority Affairs, 18(1), 53-72. DOI: https://doi.org /10.1080/13602009808716393 
Hassanpour, A. (2012). The indivisibility of the nation and its linguistic divisions. International Journal of the Sociology of Language, 217, 49-73. DOI: https://doi.org/10.1515/ijsl-2012-0049

Hassanpour, A., \& Mojab, S. (2005). Kurdish diaspora. In M. Ember, C. L. Ember \& I. Skoggard (Eds.), Encyclopedia of diasporas. Part I. Immigrant and refugee cultures around the world (pp. 214-224). Boston: Springer Science + Business Media.

Hassanpour, A., Sheyholislami, J., \& Skutnabb-Kangas, T. (2012). Introduction. Kurdish: Linguicide, resistance and hope. International Journal of the Sociology of Language, 217, 1-18. DOI: https://doi.org /10.1515/ijsl-2012-0047

Hautaniemi, P., Juntunen, M., \& Sato, M. (2013). Return migration and vulnerability: Case studies from Somaliland and Iraqi Kurdistan. Helsinki: University of Helsinki.

Henn, M., Weinstein, M., \& Forrest, S. (2005). Uninterested youth? Young people's attitudes towards party politics in Britain. Political Studies, 53(3), 556-578. DOI: https://doi.org/10.1111/j.1467-9248 .2005.00544.x

Hess, D., \& Martin, B. (2006). Repression, backfire, and the theory of transformative events. Mobilization: An International Journal, 11(2), 249267. DOI: https://doi.org/10.17813/maiq.11.2.3204855020732v63

Hess, M., \& Korf, B. (2014). Tamil diaspora and the political spaces of second-generation activism in Switzerland. Global Networks, 14(4), 419-437. DOI: https://doi.org/10.1111/glob.12052

Hirsch, M. (1997). Family frames: Photography, narrative, and postmemory. Cambridge, MA: Harvard University Press.

Hirsch, M. (2008). The generation of postmemory. Poetics Today, 29(1), 103-128. DOI: https://doi.org/10.1215/03335372-2007-019

Hourani, G. (2012). Transnationalism from above: Homeland political parties of Lebanon and the Lebanese diaspora. Retrieved 9 March 2021, from: https://ssrn.com/abstract=2211406

Houston, C. (2005). Creating a diaspora within a country: Kurds in Turkey. In M. Ember, C. R. Ember, \& I. Skoggard (Eds.), Encyclopedia of diasporas (pp. 403-414). Boston, MA: Springer. DOI: https://doi .org/10.1007/978-0-387-29904-4_40

Human Rights Watch. (1991). Human Rights World Report 1990 Turkey. Retrieved 9 March 2021, from http://www.refworld.org /docid/467fca3ab.html

Human Rights Watch. (2004). Claims in conflict. Reversing ethnic cleansing in northern Iraq, 16, 4. Retrieved 9 March 2021, from http://www .hrw.org/reports/2004/iraq0804/iraq0804.pdf 
Human Rights Watch. (2012). Time for justice. Ending impunity for killings and disappearances in 1990s Turkey. Human Rights Watch. Retrieved 9 March 2021, from http://www.hrw.org/sites/default /files/reports/turkey0912ForUpload.pdf

Hylland Eriksen, T. (1993). Ethnicity and nationalism. Anthropological perspectives. London: Pluto Press. DOI: https://doi.org/10.2307 /2804409

Inglehart, R., \& Welzel, C. (2005). Modernization, cultural change, and democracy: The human development sequence. New York: Cambridge University Press. DOI: https://doi.org/10.1017/CBO9780511790881

Insel, A. (2007). Kemalismi - huoli valtion eheydestä. In A. Leinonen, T. Kojo, M. Nousiainen, S. Peltonen, \& L. Tainio (Eds.), Turkki. Euroopan rajalla? (pp. 121-135). Helsinki: Gaudeamus.

Itzigsohn, J., Dore Cabral, C., Hernandez Medina, E., \& Vazquez, O. (1999). Mapping Dominican transnationalism: Narrow and broad transnational practices. Ethnic and Racial Studies, 22(2), 316-339. DOI: https://doi.org/10.1080/014198799329503

Itzigsohn, J., \& Saucedo, S. G. (2002). Immigrant incorporation and sociocultural transnationalism. International Migration Review, 36(3), 766-798. DOI: https://doi.org/10.1111/j.1747-7379.2002.tb00104.x Ireland, P. (1994). The policy challenge of ethnic diversity. Immigrant politics in France and Switzerland. Cambridge, MA: Harvard University Press. DOI: https://doi.org/10.2307/2547173

Jongerden, J., \& Akkaya, A. H. (2011). Born from the left: The making of the PKK. In M. Casier \& J. Jongerden (Eds.), Nationalisms and politics in Turkey: Political Islam, Kemalism and the Kurdish issue (pp. 123-142). London: Routledge. DOI: https://doi.org/10 $.4324 / 9780203847060$

Jongerden, J., \& Akkaya, A. H. (2013). Democratic confederalism as a Kurdish spring: The PKK and the quest for radical democracy. In M. Ahmet \& M. M. Gunter (Eds.), The Kurdish spring: Geopolitical changes and the Kurds (pp. 163-185). Costa Mesa: Mazda.

Jongerden, J., \& Akkaya, A. H. (2016). Kurds and the PKK. In J. Stone, R. M. Dennis, P. S. Rizova, A. D. Smith, \& X. Hou (Eds.), The Wiley Blackwell encyclopedia of race, ethnicity, and nationalism (pp. 1-5). Chichester: Wiley-Blackwell. DOI: https://doi.org /10.1002/9781118663202.wberen026

Karagöz, Z. (2017). The Kurdish diasporic mobilization in France: From restricted political national frame to a translocal sphere of contention? The case of Kurds in Marseille. Journal of Mediterranean Knowledge, 2(1), 79-100. DOI: https://doi.org/10.26409/2017JMK2.1.05 
Kardaş, T., \& Yesiltaş, M. (2017). Rethinking Kurdish geopolitical space: The politics of image, insecurity and gender. Cambridge Review of International Affairs, 30(2-3), 256-282. DOI: https://doi.org/10.1080 /09557571.2017.1410098

Karim, J. S. (2016). Qui suis-je, kurde ou français(e)? Etude sur les identités personnelles chez les jeunes kurdes en France (Master's thesis, University of Oslo, Oslo).

Kasinitz, P., Waters, M., Mollenkopf, J., \& Anil, M. (2002). Transnationalism and the children of immigrants in contemporary New York. In P. Levitt \& M. Waters (Eds.), The changing face of home: The transnational lives of the second generation (pp. 96-122). New York: Russell Sage Foundation.

Kastoryano, R. (2002). Negotiating identities: States and immigrants in France and Germany. Princeton, NJ: Princeton University Press. DOI: https://doi.org/10.2307/20033194

Kaya, Z. \& Whiting, M. (2017). Sowing division: Kurds in the Syrian War. Middle East Policy 24(1), 79-91. DOI: https://doi.org/10.1111 /mepo.12253

Khayati, K. (2008). From victim diaspora to transborder citizenship. Diaspora formation and transnational relations among Kurds in France and Sweden (Doctoral dissertation, Linköping University, Linköping).

King, R., \& Christou, A. (2010). Cultural geographies of counterdiasporic migration: Perspectives from the study of second-generation 'returnees' to Greece. Population, Space and Place 15(2), 103119. DOI: https://doi.org/10.1002/psp.543

King, R., \& Christou, A. (2014). Second-generation 'return' to Greece: New dynamics of transnationalism and integration. International Migration, 52(6), 85-99. DOI: https://doi.org/10.1111/imig.12149

Kissau, K. (2012).Structuring migrants' political activities on the Internet: A two-dimensional approach. Journal of Ethnic and Migration Studies, 38(9), 1381-1403. DOI: https://doi.org/10.1080/1369183X .2012 .698207

Kissau, K., \& Hunger, U. (2010). The internet as a means of studying transnationalism and diaspora. In R. Bauböck \& T. Faist (Eds.), Diaspora and transnationalism: Concepts, theories and methods (pp. 245-266). Amsterdam: Amsterdam University Press. DOI: https://doi.org/10.5117/9789089642387

Kitanova, M. (2019). Youth political participation in the EU: Evidence from cross-national analysis. Journal of Youth Studies, 23(7), 819-836. DOI: https://doi.org/10.1080/13676261.2019.1636951 
Kivisto, P. (2001). Theorizing transnational immigration: A critical review of current efforts. Ethnic and Racial Studies, 24(4), 549-577. DOI: https://doi.org/10.1080/01419870120049789

Klein, J. (2015). Kurdish identity in the Ottoman Empire. In W. Taucher, M. Vogl, \& P. Webinger (Eds.), The Kurds. History, religion, language, politics (pp. 8-21). Vienna: Austrian Federal Ministry of the Interior. Kleist, N. (2008a). Agents of development and change. The Somali diaspora at work. In R. Bardouille, M. Grieco, \& M. Ndulo (Eds.), Africa's finances: The contribution of remittances (pp. 97-115). Newcastle upon Tyne: Cambridge Scholars Publishing.

Kleist, N. (2008b). Mobilising 'the diaspora': Somali transnational political engagement. Journal of Ethnic and Migration Studies, 34(2), 307-323. DOI: https://doi.org/10.1080/13691830701823855

Knapp, M., Flach, A., \& Ayboga, E. (2016). Revolution in Rojava. Democratic Autonomy and Women's Liberation in Syrian Kurdistan. London: Pluto Press.

Koçer, S. (2014). Kurdish cinema as a transnational discourse genre: Cinematic visibility, cultural resilience, and political agency. International Journal of Middle East Studies, 46(3), 473-488. DOI: https:// doi.org/10.1017/S0020743814000555

Koinova, M. (2018). Critical junctures and transformative events in diaspora mobilisation for Kosovo and Palestinian statehood. Journal of Ethnic and Migration Studies, 44(8), 1289-1308. DOI: https://doi .org/10.1080/1369183X.2017.1354158

Koopmans, R. (2004). Migrant mobilisation and political opportunities: Variation among German cities and a comparison with the United Kingdom and the Netherlands. Journal of Ethnic and Migration Studies, 30(3), 449-470. DOI: https://doi.org/10.1080/13691830410 001682034

Koopmans, R., \& Statham, P. (2003). How national citizenship shapes transnationalism: A comparative analysis of migrant and minority claims-making in Germany, Great Britain and the Netherlands. In C. Joppke \& E. Morawska (Eds.), Toward assimilation and citizenship: Immigrants in liberal nation-states (pp. 195-238). Basingstoke: Palgrave Macmillan Ltd.

Kreyenbroek, P. (1991). Kurds: A contemporary overview. New York: Routledge.

Kurban, D. (2014). Europe as an agent of change. The role of the European Court of Human Rights and the EU in Turkey's Kurdish policies (SWP Working paper, Stiftung Wissenschaft und Politik, Berlin). 
Lee, H. (Ed.). (2008). Ties to the homeland: Second generation transnationalism. Newcastle: Cambridge Scholars Publishing.

Lee, H. (2011). Rethinking transnationalism through the second generation. The Australian Journal of Anthropology, 22(3), 295-313. DOI: https://doi.org/10.1111/j.1757-6547.2011.00150.x

Leezenberg, M. (2005). Iraqi Kurdistan: Contours of a post-civil war society. Third World Quarterly, 26(4-5), 631-647. DOI: https://doi .org/10.1080/01436590500127867

Lettinga, D., \& Shaharso, S. (2009). Débats sur le « voile musulman » en France et aux Pays-Bas. Migrations société, 2(122), 237-276.

Levitt, P. (2009). Roots and routes: Understanding the lives of the second-generation transnationally. Journal of Ethnic and Migration Studies, 35(7), 1225-1242. DOI: https://doi.org/10.1080/13691830 903006309

Levitt, P., \& Glick Schiller, N. (2004). Conceptualizing simultaneity: A transnational social field perspective on society. International Migration Review, 38(3), 1002-1039. DOI: https://doi.org/10.1111 /j.1747-7379.2004.tb00227.x

Levitt, P., \& Jarowsky, N. (2007). Transnational migration studies: Past developments and future trends. Annual Review of Sociology, 33, 129156. DOI: https://doi.org/10.1146/annurev.soc.33.040406.131816

Levitt, P., \& Waters, M. C. (Eds.). (2006). The changing face of home: The transnational lives of the second generation. New York: Russell Sage Foundation. DOI: https://doi.org/10.1177/009430610403300345

Macdonald, S. (2012). Presencing Europe's pasts. In U. Kockel, M. NicCraith \& J. Frykman (Eds.), A companion to the anthropology of Europe (pp. 233-252). Oxford: Blackwell.

Mahéo, V.-A., Dejaeghere, Y., \& Stolle, D. (2012). La non-participation politique des jeunes: Une étude des barrières temporaires et permanentes de l'engagement. Canadian Journal of Political Science, 45(2), 405-425. DOI: https://doi.org/10.1017/S0008423912000388

Mahmod, J. (2016). Kurdish diaspora online: From imagined community to managing communities. New York: Palgrave Macmillan.

Mannheim, K. (1952). The problem of generations. In K. Mannheim (Ed.), Essays on the Sociology of Knowledge. London: RKP.

Marchand, L. (2017). Triple assassinat au 147, rue La Fayette. Arles: Solin/Actes sud.

Martin, N. (2018). The A.K. Party and the Kurds since 2014: A discourse of terror. British Journal of Middle Eastern Studies, 45(4), 543-558. DOI: https://doi.org/10.1080/13530194.2018.1430531 
Mason, V. (2007). Children of the 'idea of Palestine': Negotiating identity, belonging and home in the Palestinian diaspora. Journal of Intercultural Studies, 28(3), 271-285. DOI: https://doi.org/10.1080 /07256860701429709

McDowall, D. (1996). A modern history of the Kurds. New York: IB Tauris \& Co Ltd.

Mavroudi, E. (2018). Deconstructing diasporic mobilisation at a time of crisis: Perspectives from the Palestinian and Greek diasporas. Journal of Ethnic and Migration Studies, 44(8), 1309-1324. DOI: https:// doi.org/10.1080/1369183X.2017.1354159

Meyer, D. \& Minkoff, D. (2004). Conceptualizing political opportunity. Social Forces 82(4), 1457-1492. DOI: https://doi.org/10.1353 /sof.2004.0082

Mickolus, E., \& Simmons, S. (1997). Terrorism, 1992-1995. A chronology of events and a selectively annotated bibliography. London: Greenwood.

Mlodoch, K. (2012). Fragmented memory, competing narratives: The perspective of women survivors of the Anfal operations in Iraqi Kurdistan. In J. Tejel, P. Sluglett, \& R. Bocco (Eds.), Writing the modern history of Iraq: Historiographical and political challenges (pp. 205-226). London: World Scientific Publishing. DOI: https:// doi.org/10.1142/9789814390576_0014

Mohammed, H. (2016). L'invention d'un Parlement. Genèse et autonomisation de l'institution parlementaire de la Région du Kurdistan irakien 1992-2009. Contribution à une sociologie des institutions politiques (Doctoral dissertation, EHESS, Paris).

Mohseni, C. (1999). La communauté des réfugiés Kurdes irakiens en France: Modes de vie et intégrations (Doctoral dissertation, Université de Paris III Sorbonne, Paris).

Mohseni, C. (2003). La deuxième génération kurde en France au carrefour de repères fluctuants. Paris: Institut kurde de Paris.

Morris, A. (2000). Charting futures for sociology: Social organization reflections on social movement theory: Criticisms and proposals. Contemporary Sociology - a Journal of Reviews, 29(3), 445-454. DOI: https://doi.org/10.2307/2653931

Moss, D. (2016). The Arab Spring abroad: Mobilization among Syrian, Libyan, and Yemeni diasporas in the U.S. and Great Britain (Doctoral dissertation, University of California, California).

Middle East Watch. (1993). Genocide in Iraq. The Anfal campaign against the Kurds. Middle East Watch. 
Mügge, L. (2010). Beyond Dutch borders: Transnational politics among colonial migrants, guest workers and the second generation. Amsterdam: Amsterdam University Press. DOI: https://doi.org/10.1515 19789048512829

Müller-Funk, L. (2016). Diaspora mobilizations in the Egyptian (post) revolutionary process: Comparing transnational political participation in Paris and Vienna. Journal of Immigrant \& Refugee Studies, 14(3), 353-370. DOI: https://doi.org/10.1080/15562948.2016.1180471

Müller-Funk, L. (2020). Fluid identities, diaspora youth activists and the (Post-)Arab Spring: how narratives of belonging can change over time. Journal of Ethnic and Migration Studies, 46(6), 1112-1128. DOI: https://doi.org/10.1080/1369183X.2018.1554300

Muxel, A. (2002). La participation politique des jeunes: Soubresauts, fractures et ajustements. Revue française de science politique, 52(5), 521-544.

Natali, D. (2005). The Kurds and the state. Evolving national identity in Iraq, Turkey and Iran. New York: Syracuse University Press. DOI: https://doi.org/10.1017/S0020743807070602

Nell, L. M. (2008). Transnational migrant politics in the Netherlands: Historical structures and current events (Doctoral dissertation, Amsterdam University, Amsterdam).

Norris, P. (2002). Democratic phoenix: Reinventing political activism. Cambridge, New York: Cambridge University Press. DOI: https:// doi.org/10.1017/CBO9780511610073

Norwegian Refugee Council. (2005). IDP: Profile of internal displacement: Turkey. Retrieved 9 March 2021, from https://www.refworld .org/publisher,IDMC,TUR,50ffbce5274,0.html

Orjuela, C. (2018). Mobilising diasporas for justice. Opportunity structures and the presencing of a violent past. Journal of Ethnic and Migration Studies, 44(8), 1357-1373. DOI: https://doi.org/10.1080 /1369183X.2017.1354163

O'Toole, T. (2003). Engaging with young people's conceptions of the political. Children's Geographies, 1(1), 71-90. DOI: https://doi.org /10.1080/14733280302179

O’Toole, T., \& Gale, R. (2010). Contemporary grammars of political action among ethnic minority young activists. Ethnic and Racial Studies, 33(1), 126-143. DOI: https://doi.org/10.1080/01419870903118122

O’Toole, T., \& Gale, R. (2013). Political engagement amongst ethnic minority young people. Making a difference. Basingstoke: Palgrave Macmillan. DOI: https://doi.org/10.1057/9781137313317 
O’Toole, T., Marsh, D., \& Jones, S. (2003). Political literacy cuts both ways: The politics of non-participation among young people. The Political Quarterly, 74(3), 349-360. DOI: https://doi.org/10.1111/1467 -923X.00544

Pearlman, W. (2014). Competing for Lebanon's diaspora: Transnationalism and domestic struggles in a weak state. International Migration Review, 48(1), 34-75. DOI: https://doi.org/10.1111/imre.12070

Petek, G., \& Poinsot, M. (2015). La population turque dans le $10^{\mathrm{e}}$ arrondissement de Paris. Entretien avec Rémi Féraud, maire du $10^{\mathrm{e}}$ arrondissement de Paris depuis 2008. Hommes \& Migrations, 1312, 114-118.

Pirkkalainen, P. (2013). Transnational responsibilities and multi-sited strategies: Voluntary associations of Somali diaspora in Finland (Doctoral dissertation, University of Jyväskylä, Jyväskylä).

Portes, A., Guarnizo, L., \& Landolt, P. (1999). The study of transnationalism: Pitfalls and promises of an emergent research field. Ethnic and Racial Studies, 22(2), 217-237. DOI: https://doi.org /10.1080/014198799329468

Portes, A., \& Rumbaut, R. G. (2001). Legacies. The story of immigrant second generation. Berkeley, CA: University of California Press.

Portes, A., \& Zhou, M. (1993). The new second generation: Segmented assimilation and its variants. Annals of the American Academy of Political and Social Science, 530, 74-96. DOI: https://doi.org /10.1177/000271629353000106

Pratsinakis, M. (2017). Established and outsider nationals: Immigrantnative relations and the everyday politics of national belonging. Ethnicities, 18(1), 3-22. DOI: https://doi.org/10.1177/1468796817692838

Premazzi, V., Ambrosetti, E., Fokkema, T., \& Cela, E. (2013). The Arab Spring and the return intention of Egyptian migrants living in Italy. International Journal of Euro-Mediterranean Studies, 6(2), 109-131. DOI: https://doi.org/10.4000/remi.8481

Pries, L. (2005). Configurations of geographical and societal spaces: A sociological proposal between 'methodological nationalism' and the 'spaces of flows'. Global Networks. A Journal of Transnational Affairs, 5(2), 167-190. DOI: https://doi.org/10.1111/j.1471 -0374.2005.00113.x

Potter, R. B. (2005). 'Young, gifted and back': Second-generation transnational return migrants to the Caribbean. Progress in Development Studies, 5(3), 213-236. DOI: https://doi.org/10.1191/1464993405ps114oa Quinsaat, S. (2019). Diasporas as social movements? In R. Cohen \& C. Fischer (Eds.), Routledge Handbook of Diaspora Studies (pp. 47-54). Abingdon: Routledge. DOI: https://doi.org/10.4324/9781315209050 
Quinsaat, S. M. (2013). Migration mobilization for homeland politics: A social movement approach. Sociology Compass, 7(11), 952-964. DOI: https://doi.org/10.1111/soc4.12086

Rigoni, I. (1998). Les mobilisations des Kurdes en Europe. Revue Européenne des Migrations Internationales, 14-3, 203-223.

Rigoni, I. (2000). Med-TV dans le conflit kurde. Confluences Méditerranée, $34,45-52$.

Romano, D. (2002). Modern communications technology in ethnic nationalist hands: The case of the Kurds. Canadian Journal of Political Science, 35(1), 127-149. DOI: https://doi.org/10.1017/S0008423902778207

Ross, A. (2019). Finding political identities. Young people in changing Europe. London: Palgrave Macmillan. DOI: https://doi.org/10.1007 1978-3-319-90875-5

Rumbaut, R. G. (2004). Ages, life stages and generational cohorts. International Migration Review, 38(3), 1160-1205. DOI: https://doi .org/10.1111/j.1747-7379.2004.tb00232

Safran, W. (1991). Diasporas in modern societies: Myths of homeland and return. Diaspora, 1(1), 83-99. DOI: https://doi.org/10.1353/dsp .1991 .0004

Safran, W. (2007). Concepts, theories, and challenges of diaspora: A panoptic approach. Paper presented at Conference Dispersione, globalizzazione e costruzione dell'alterità: diaspore et migrazioni nel bacino del Mediterraneo et oltre, University of Pisa, Italy.

Sassen, S. (2005). The global city. New York, London, Tokyo. Princeton, NJ, Oxford: Princeton University Press. DOI: https://doi.org/10 $.2307 / 2152688$

Scheffer, G. (2003). Diaspora politics. At home abroad. New York: Cambridge University Press. DOI: https://doi.org/10.1017/CBO97 80511499432

Schindlmayr, T. (2003). Sovereignty, legal regimes, and international migration. International Migration, 41(2), 109-123. DOI: https://doi .org/10.1111/1468-2435.00237

Schøtt, A. S. (2017). From the forgotten people to world-stage actors. The Kurds of Syria. Copenhagen: Royal Danish Defense College.

Schøtt, A. S. (2021 forthcoming). Kurdish diaspora mobilisation in Denmark: Supporting the struggle in Syria. Edinburgh: Edinburgh University Press.

Sentas, V. (2015). Policing the diaspora: Kurdish Londoners, MI5 and the proscription of terrorist organizations in the United Kingdom. British Journal of Criminology, 56(5), 898-918. DOI: https://doi.org /10.1093/bjc/azv094 
Sentas, V. (2018). Terrorist organization proscription as counterinsurgency in the Kurdish conflict. Terrorism and Political Violence, 30(2), 298-317. DOI: https://doi.org/10.1080/09546553.2018.1432215

Shahvisi, A. (2018). Beyond Orientalism: Exploring the distinctive feminism of democratic confederalism in Rojava. Geopolitics. Published online. DOI: https://doi.org/10.1080/14650045.2018.1554564

Shain, Y., \& Barth, A. (2003). Diasporas and international relations theory. International Organization, 57(3), 449-479. DOI: https://doi .org/10.1017/S0020818303573015

Sheyholislami, J. (2010). Identity, language and new media: The Kurdish case. Language Policy, 9(4), 289-312. DOI: https://doi.org/10.1007 /s10993-010-9179-y

Sheyholislami, J. (2011). Kurdish identity, discourse and new media. New York: Palgrave Macmillan. DOI: https://doi.org/10.1057/97802 30119307

Silverman, M. (1992). Deconstructing the nation. Immigration, racism and citizenship in modern France. London: Routledge. DOI: https:// doi.org/10.4324/9780203407431

Silverstein, P. (2004). Algeria in France: Transpolitics, race and nation. Bloomington, IN: Indiana University Press.

Şimşek, B., \& Jongerden, J. (2018). Gender revolution in Rojava: The voices beyond tabloid geopolitics. Geopolitics, published online. DOI: https://doi.org/10.1080/14650045.2018.1531283

Sinclair, C., \& Smets, K. (2014). Media freedoms and covert diplomacy: Turkey challenges Europe over Kurdish broadcasts. Global Media and Communication, 10(3), 319-331. DOI: https://doi.org /10.1177/1742766514552380

Skutnabb-Kangas, T., \& Fernandes, D. (2008). Kurds in Turkey and in (Iraqi) Kurdistan: A comparison of Kurdish educational language policy in two situations of occupation. Genocide Studies and Prevention, 3(1), 43-73. DOI: https://doi.org/10.3138/gsp.3.1.043

Sloam, J., \& Henn, M. (2019). Rejuvenating politics: Young political participation in a changing world. In J. Sloam \& M. Henn (Eds.), Youthquake 2017. The rise of young cosmopolitans in Britain (pp. 17-42). Cham: Palgrave Pivot. DOI: https://doi.org/10.1007/978-3 -319-97469-9_2

Smets, K. (2016). Ethnic media, conflict, and the nation-state: Kurdish broadcasting in Turkey and Europe and mediated nationhood. Media Culture \& Society, 38(5), 738-754. DOI: https://doi.org/10 .1177/0163443715620928 
Smets, K., \& Sengul, A. F. (2016). Kurds and their cultural crossroads. Kurdish identity, media and cultural production. Middle East Journal of Culture and Communication, 9(3), 247-256. DOI: https://doi .org/10.1163/18739865-00903006

Somerville, K. (2008). Transnational belonging among second generation youth: Identity in a globalized world. Journal of Social Sciences, $10,23-33$.

Sökefeld, M. (2006). Mobilizing in transnational space: A social movement approach to the formation of diaspora. Global Networks, 6(3), 265-284. DOI: https://doi.org/10.1111/j.1471-0374.2006.00144.x

Squire, V. (2009). The exclusionary politics of asylum. Basingstoke: Palgrave Macmillan.

Taucher, W., Vogl, M., \& Webinger, P. (2015). The Kurds: history, religion, language, politics. Vienna: Austrian Federal Ministry of the Interior.

Teerling, J. (2011). The development of new 'third-cultural spaces of belonging': British-born Cypriot 'return' migrants in Cyprus. Journal of Ethnic and Migration Studies, 37(7), 1079-1099. DOI: https://doi .org/10.1080/1369183X.2011.572484

Tejel, J. (2009). Syria's Kurds: History, politics and society. New York: Routledge.

Tejel, J. (2014). Toward a generational rupture within the Kurdish movement in Syria? In O. Bengio (Ed.), Kurdish awakening. Nation building in a fragmented homeland (pp. 215-229). Austin, TX: University of Texas Press.

Tekdemir, Ö., Toivanen, M., \& Baser, B. (2018). Peace profile: Academics for peace in Turkey. Peace Review, 30(1), 103-111. DOI: https:// doi.org/10.1080/10402659.2017.1419968

Toivanen, M. (2014). Negotiating home and belonging - Young Kurds in Finland (Doctoral dissertation, University of Turku, Turku).

Toivanen, M. (2019). Second generation and migrant capital in the transnational space: The case of young Kurds in France. Social Inclusion, 7(4), 243-252. DOI: https://doi.org/10.17645/si.v7i4.2328

Toivanen, M., \& Baser, B. (2016). Gender in the representation of an armed conflict: Kurdish female combatants in French and British media. Middle East Journal of Culture \& Communication, 9(3), 294314. DOI: https://doi.org/10.1163/18739865-00903007

Toivanen, M., \& Baser, B. (2018). Introduction: Methodological approaches in Kurdish studies: Politics of fieldwork, positionality and challenges ahead. In B. Baser, M. Toivanen, B. Zorlu, \& Y. Duman (Eds.), Methodological approaches in Kurdish Studies: 
Theoretical and practical insights from the field (pp. ix-xxviii). Lanham, MD: Lexington Books.

Toivanen, M., \& Baser, B. (2020). Diasporas' multiple roles in peace and conflict: A review of current debates. Migration Letters, 17(1), 47-57. DOI: https://doi.org/10.33182/ml.v17i1.753

Tsoukala, A. (2006). La légitimation des mesures d'exception dans la lutte antiterroriste en Europe. Cultures and Conflicts, 61, 25-50. DOI: https://doi.org/10.4000/conflits.2036

Uçarlar, N. (2009). Between majority power and minority resistance: Kurdish linguistic rights in Turkey (Doctoral dissertation, Lund University, Lund).

Underhill, H. (2016). Learning in revolution: Perspectives on democracy on Egypt's UK-based diaspora activists. Contemporary Levant, 1(1), 25-37. DOI: https://doi.org/10.1080/20581831.2016.1149357

Vali, A. (1998). The Kurds and their 'others': Fragmented identity and fragmented politics. Comparative Studies of South Asia, Africa and the Middle-East, XVIII(2), 82-95.

Van Bruinessen, M. (1988). Between guerrilla war and political murder: The Worker's Party of Kurdistan. Middle East Report, 153, 40-46. DOI: https://doi.org/10.2307/3012135

Van Bruinessen, M. (1992). Agha, shaikh and state. The social and political structures of Kurdistan. New York: Zed Books.

Van Bruinessen, M. (1998). Shifting national and ethnic identities: the Kurds in Turkey and the European Diaspora. Journal of Muslim Minority Affairs 18(1), 39-52. DOI: https://doi.org/10.1080/1360 2009808716392

Van Bruinessen, M. (1999a). The Kurds and Islam (Working paper 13, Islamic Area Studies Project, Tokyo). Retrieved 9 March 2021, from https://dspace.library.uu.nl/bitstream/handle/1874/20693/bruinessen _98_kurdsandislam.pdf? sequence $=1$

Van Bruinessen, M. (1999b). The Kurds in movement: Migrations, mobilisations, communications and the globalisation of the Kurdish question (Working Paper 14, Islamic Area Studies Project, Tokyo). Retrieved 9 March 2021, https://www.researchgate.net/publication/27703223 _The_Kurds_in_movement_migrations_mobilisations_communi cations_and_the_globalisation_of_the_Kurdish_question_Working _Paper_no_14

Van Bruinessen, M. (2000). Transnational aspects of the Kurdish question (Working paper, European University Institute, Florence). Retrieved 9 March 2021 from http://cadmus.eui.eu/handle/1814/1662 
Van de Bos, M., \& Nell, L. (2006). Territorial bounds to virtual space: Transnational online and offline networks of Iranian and TurkishKurdish immigrants in the Netherlands. Global Networks, 6(2), 201220. DOI: https://doi.org/10.1111/j.1471-0374.2006.00141.x

Van Mol, C., \& de Valk, H. A. G. (2016). Migration and immigrants in Europe: A historical and demographic perspective. In B. GarcesMascarenas \& R. Penninx (Eds.), Integration processes and policies in Europe. Contexts, levels and actors (pp. 31-55). Springer. Retrieved 9 March 2021 from: https://www.springer.com/gp/book 19783319216737

Vertovec, S. (1999). Conceiving and researching transnationalism. Ethnic and Racial Studies, 22(2), 447-462. DOI: https://doi.org /10.1080/014198799329558

Vertovec, S. (2009). Transnationalism. New York: Routledge. DOI: https://doi.org/10.4324/9780203927083

Volkan, V. D. (2001). Transgenerational transmissions and chosen traumas: An aspect of large-group identity. Group Analysis, 34(1), 79-97. DOI: https://doi.org/10.1177/05333160122077730

Wahlbeck, Ö. (1999). Kurdish diasporas. A comparative study of Kurdish refugee communities. London: Macmillan.

Wahlbeck, Ö. (2005). Kurds in Finland. In M. Ember, C. L. Ember \& I. Skoggard (Eds.), Encyclopedia of diasporas. Immigrant and refugee cultures around the world (pp. 1004-1010). Boston, MA: Springer Science + Business Media.

Wahlbeck, Ö. (2007). The Kurds in Europe. In A. Kumar Sahoo \& B. Maharaj (Eds.), Sociology of diaspora: A reader (pp. 443-471). New Delhi: Rawat.

Waldinger, R. (2015). The cross-border connection. Immigrants, emigrants, and their homelands. Harvard: Harvard University Press. DOI: https://doi.org/10.4159/harvard.9780674736283

Wahlbeck, Ö. (2019). The future of the Kurdish diaspora. In M. Gunter (Ed.), Routledge Handbook on the Kurds (pp. 413-424). London: Routledge. DOI: https://doi.org/10.4324/9781315627427

Weinzimmer, J. M. (2008). The distant reach of the Middle East: How perceptions of conflict affect Jewish Israeli American and Palestinian American identity (Doctoral dissertation, Duke University, Durham, NC).

White, P. J. (2000). Primitive rebels or revolutionary modernizers?: The Kurdish national movement in Turkey. New York: Zed Books.

Wieviorka, M. (2005). After new social movements. Social Movement Studies, 4(1),1-19.DOI:https://doi.org/10.1080/14742830500051812 
Wimmer, A., \& Glick Schiller, N. (2002). Methodological nationalism and beyond: Nation-state building, migration and the social sciences. Global Networks, 2(4), 301-334. DOI: https://doi.org/10.1111/1471 $-0374.00043$

Yanmis, M. (2016 February). Resurgence of the Kurdish conflict in Turkey: How Kurds view it. Rethink paper 25. Retrieved 9 March 2021 from: https://www.pi.org.hk/wp-content/uploads/2015/12/Resurgence -of-Kurdish-Conflict-Mehmet-Yanmis.pdf

Yildiz, K. (2007). The Kurds in Iraq. Past, present and future. London: Pluto.

Yüksel-Pecen, A. S. (2018). Representation of terror and ethnic conflict in the Turkish press: An analysis of the peace process in Turkey. Middle East Critique, 27(2), 207-219. DOI: https://doi.org/10.1080/1943 6149.2018.1443848

Zeydanlıoğlu, W. (2008). The white Turkish man's burden': Orientalism, Kemalism and the Kurds in Turkey. In G. Rings \& A. Ife (Eds.), Neocolonial mentalities in contemporary Europe? Language and discourse in the construction of identities (pp. 155-174). Newcastle upon Tyne: Cambridge Scholars Publishing.

Zeydanlığlu, W. (2009). Torture and turkification in the Diyarbakir military prison. In W. Zeydanlığlu \& J. T. Parry (Eds.), Rights, citizenship \& torture: Perspectives on evil, law and the state (pp. 73-92). Oxford: Inter-Disciplinary Press.

Zeydanlığlu, W. (2012). Turkey's Kurdish language policy. International Journal of the Sociology of Language, 217, 99-125. DOI: https://doi .org/10.1515/ijsl-2012-0051

Østergaard-Nielsen, E. (2001). Transnational political practices and the receiving state: Turks and Kurds in Germany and the Netherlands. Global Networks, 1(3), 261-282. DOI: https://doi.org/10.1111/1471 $-0374.00016$

Østergaard-Nielsen, E. (2003). The politics of migrants' transnational political practices. International Migration Review, 37(3), 760-786. DOI: https://doi.org/10.1111/j.1747-7379.2003.tb00157.x

Ögelman, N. (2003). Documenting and explaining the persistence of homeland politics among Germany's Turks. International Migration Review, 37(1), 163-193. DOI: https://doi.org/10.1111/j .1747-7379.2003.tb00133.x

Özdag, Ü. (2003). The PKK and low intensity conflict in Turkey. London: Cass. 


\section{Index}

Page numbers in italic refer to illustrations; page numbers in bold indicate a table.

A

Abdullah, Nessrin $\quad 150,153$

Adamson, Fiona B. 35, 93, 150, 151,218

Afrin $6,70,73$

Ahmet Kaya Kurdish Cultural

Center 156

Akgönül, Samim 132

Akkaya, Ahmet Hamdi 93

AKP (Justice and Development Party) 132

Al Qaeda 109

Alinejad, Donya $180,182,191$

Alinia, Minoo 34, 46

alter-territoriality $28,118,205$

Ambition kurde 166, 178

Andén-Papadopoulos, Kari 139

Anderson, Benedict 22

Anfal campaign $\quad 35,67,87$

angel of Kobane ('Rehana') 181

Anthias, Floya 25, 41, 196, 211, 212, 217, 219

Arab nationalism $\quad 63,65$
Arab Spring $10,43,69,128$

assassination of Kurdish activists in Paris 124

cultural responses 144

families' treatment 160

France-Kurdistan Association created in response 140 as host country event 38 , 127,169

as mobilising event $\quad 114,169$

visibility given to 138

asylum-seekers $\quad 81,83,85,103$

Atatürk, Mustafa Kemal 60

Azad (interviewee) 83, 84

B

Ba'athists 64,65

Bakûr see Turkish Kurdistan

Barth, Aharon 128

Barzani tribe 66

Barzani, Massoud 77

Barzani, Sirwan 137 

Baser, Bahar $14,100,124,127$, 147, 157, 176, 206
Başûr see Iraqi Kurdistan
BBC 5, 182
Belgium 98, 158
Berivan (interviewee) 83
broadcasting $96,98,101,110$, 121, 158
Brubaker, Rogers $31,32,36$, 107, 210
bureaus of representation for Rojava 138

C

Cansız, Sakine 124 see also assassination of Kurdish activists in Paris

Casier, Marlies 108, 129

CDK-F (Conseil démocratique kurde en France, formerly FEYKA) 94, 125

census statistics $\quad 90,102,105$

Charlie Hebdo terrorist attacks $109,123,154$

Chaudhary, Ali R. 40, 131, 140, $142,143,146$

'Chemical Ali' (Ali Hassan al-Majid) 66 children of migrants see second generation

Chimienti, Milena 211

CHP (Republican People's Party) 133

cinema 96, 144

Ciordia, Alejandro $\quad 74,78$

citizenship

European statistics 90

French 104, 109, 146, 156 and international mobility 27 Syrian 64,70 class 197

Cohen, Robin 30

Comte, Antoine 109, 156

Congrès national du Kurdistan see Kurdistan National Congress (KNK)

Coquerel, Eric 137

Costa, Elisabetta $\quad 180,182,191$ cross-national diffusion 78 cultural and social activities 18 , $95,143,178$

cultural pluralism 105

D

Daesh see ISIS (Islamic State)

Dahinden, Janine 22, 25, 173,210

DBP (Democratic Regions Party) 75

della Porta, Donatella 218

Demirtaş, Selahattin $\quad 75,132$

Democratic Party of Kurds in Syria (DPKS) 64

Democratic Regions Party

(DBP) 75

Democratic Union Party (PYD)

$12,71,72,120,123,152$

demonstrations

French authorities and 157

Gezi Park protests 43,135

for Abdullah Öcalan's release

$33,95,115,148,200$

post-Kobane $\quad 5,6,18,74$,

118,121

post-Paris assassinations

124,125

as semi-institutional

activities 141,142

as places of socialisation 200

Denmark 99, 118, 158, 172, 178 
diaspora mobilisation 33 events triggering $7,34,114$, $169,202,214$

factors affecting 145

global cities 218

national context 37,45

repertoires of action $\quad 33,130,165$

transnational context $34,39,118$

diasporas 30

alter-territoriality of $28,118,205$

internal displacement and 91

as non-state actors 9

as products of mobilisation 36

theoretical approach 13

see also Kurdish diaspora;

diaspora mobilisation

diasporic circulation 48

diasporic consciousness $\quad 169,204$

digital media see online activities

disappearances 88

displacement, forced 86,102 , 103, 209

Doğan, Fidan 124

dormant transnationalists 128

DPKS (Democratic Party of

Kurds in Syria) 64

E

Eastern Kurdistan see Iranian

Kurdistan

Eccarius-Kelly, Vera 6, 120, 121,

$129,162,171,172,203$

economic migrants $81,84,85$,

94, 102, 103, 104

education (class) 197

educational activities $\quad 178$

Egyptian diaspora in

Vienna 203

electoral activities 131

electoral monitoring $\quad 134,170$
Eliassi, Barzoo 46

Erdoğan, Recep Tayyip 7, 73,

131,132

Escafré-Dublet, Angéline 106

ethnicity 41, 176, 210

Europe

Kobane siege acknowledged by

5,121

Kurdish lobbying of

policymakers 129

migration to $81,94,102,118$

and the PKK 97, 101, 154, 158

second-generation Kurds and

171, 208

European Kurdish Democratic-

Societies Congress (KCD-E, formerly KON-Kurd)

94,132

European Parliament 5, 95, 121, 129,138

European Union $100,101,129$, 154,187

Eutelsat 110, 158

events triggering mobilisation 7 , 34, 114, 116, 169, 202, 214

Evren, Kenan 61

exile 80,83

exilic memory 206

F

family and kinship ties $\quad 170,195$ female combatants see Women's

Protection Units (YPJ)

Féraud, Rémi 95

FEYKA see CDK-F

fiche $S$ (security file) $\quad 109,154$

fieldwork 18

film festivals $\quad 96,144$

Fokkema, Tineke 49

forced migration $\quad 86,102,103,209$ 
framing 151

France 102

ambivalence towards pro-PKK activism 7, 108, 154

citizenship and integration

policies 104, 109, 146, 156

framing of Kurdish issues 153

Kurdish mobilisation 7, 94, 115, 123, 130, 135, 165

Kurdish participation in Turkish elections 131

migration to $83,94,102$

political culture 174,175

political opportunity

structures 146

second generation's role 208

size of Kurdish community

90, 103

see also assassination of Kurdish

activists in Paris; Paris

France-Kurdistan

Association 140

Franceschi, Patrice 184

Freedman, Jane 106

G

Gale, Richard 216

gender issues $153,186,196$

see also Women's Protection

Units (YPJ)

generation, use of term 17,173 ,

198, 211

generational differences 35,43 , $46,84,168,173,191,211$

genocide $4,35,67,120$

Germany $85,90,94,98,100$,

$107,157,158,176$

Gezi Park protests 43, 135

Giugni, Marco 146

global cities 217 globalisation 24

'glocal' activities 216

Gorran (Movement for

Change) 76

Gourlay, William 79,117

Grojean, Olivier $\quad 95,118,150$

groupism 210

Guéant, Claude 156

Gulf War 86

Güney, Omar 124, 125

Gysi, Gregor 138

H

Halabja 67

Hassan al-Majid, Ali

('Chemical Ali') 66

Hassanpour, Amir 101

Hautaniemi, Petri 76

HDP (People's Democratic Party) 74, 75, 132

Henri-Lévy, Bernard 137

Hess, Monika 43, 44, 49, 203, 208

heterogeneity of diasporic

communities 13, 49, 119,

172, 198, 199, 211

Hidalgo, Anne 137

Hirsch, Marianne 207

Hollande, François 7, 94, 123, $137,138,152,159,160$

homeland 30,33, 191

host countries $37,82,94,127$,

146, 208

human rights 74, 185, 208

see also genocide

humanitarian aid 141, 167

I

identity $49,55,78,93,117,151$,

$177,187,203,209$ 
independence 68

independence referendum,

KRI $12,68,77$

integration policies 104,146

internal displacement $\quad 87,91$

international media $72,100,121$,

$122,123,138,153,181,202$

international response 96,121 ,

185,187

internet see online activities

Iranian Kurdistan 55, 56, 87, 230

Iraqi Kurdistan 65,230

forced migration 86

Kurdistan Region of Iraq (KRI)

$$
12,68,75
$$

languages 55,56

peshmerga Kurdish military

forces $66,68,77,99,120$

Syrian Kurds and 68,70

Yezidi genocide 4, 56, 120

see also Kobane siege

ISIS (Islamic State)

as common enemy $72,130,184$

cultural references to combat against 144

framing of combat against 151,184

joining up to combat 99 , 142,159

Kobane siege $3,77,78,120$

November 2015 Paris attacks $109,130,155,169$

Islam 56, 107

Issa, Khaled 121, 138

Istanbul 54, 91

\section{J}

joining up to combat ISIS 99, 142,159

Jongerden, Joost 93
Justice and Development Party

(AKP) 132

K

Karagöz, Zuhal $\quad 115,136$, 152,200

Kardaş, Tuncay $\quad 182,185,189$

Kastoryano, Riva 105

KCD-E (European Kurdish

Democratic-Societies

Congress, formerly

KON-Kurd) 94, 132

KDP (Kurdish Democratic

Party) 66, 76, 77

Kemal Atatürk, Mustafa 60

KES (Kurdish-European

Society) 171

Khayati, Khalid 14,31

Khoybun League 63

kinship ties 170, 195

Klein, Janet 60

KNC (Kurdish National Council) 70, 72

KNK (Kurdistan National

Congress) 92, 109, 156

'Kobane generation', use of term

Kobane siege 3,120

as generational event 213

Iraqi Kurdish peshmerga

involvement 77

and Kurdish nationalism 78

mediatisation 181

response of second

generation $163,165,202$,

204, 205, 213

as transformative event 74,78 ,

$127,202,214$

Kobani, Zuhat 123,152

KON-Kurd see KCD-E

Korf, Benedikt $\quad 43,44,49,203,208$ 
Kouchner, Bernard 137, 138

KRG (Kurdistan Regional

Government) 12, 67, 68, 76,77

KRI (Kurdistan Region of Iraq)

$12,67,76$

Kurdayetî see Kurdish identity

Kurdish Alternative in Denmark

(KAD) 178

Kurdish Democratic Party (KDP) $66,76,77$

Kurdish diaspora

as case study 11

characterisation 31

formation 82

heterogeneous nature 13,119 , $172,198,199,211$

Kobane siege significant for 5 Kurdish nationalism and identity $79,93,97,117,151$

mobilisation history 10

organisations and

associations 92, 105, 109, $132,134,135,165,178$

relation to Kurdistan 28

semi-institutional activities

$140,165,168$

size 89,103

theoretical approach 13

see also France; Paris

Kurdish identity (Kurdayetî,

'Kurdishness') 55, 79,

$117,151,177,187$,

203, 205

see also pan-Kurdish unity

Kurdish Institute in Paris 92,

95,103

Kurdish language $\quad 55,76$

media and culture 96

prohibitions on use $60,61,62$,

64,72 second generation and 106, 207, 208

Kurdish military forces, Iraq (peshmerga) 66, 68, 77, 99,120

Kurdish National Council

(KNC) $\quad 70,72$

Kurdish nationalism $\quad 63,78,97$

Kurdish Parliament in Exile 92

Kurdish People's House

(la Maison du peuple

kurde) 109, 156

Kurdish Studies 96

Kurdish Studies Network 96

Kurdish-European Society

(KES) 171

'Kurdishness' see Kurdish identity

Kurdistan 11, 53

events sparking diaspora

mobilisation 114,116

online construction 187

second generation visits 45,

170, 195, 198

state of statelessness $\quad 58,67$,

88,201

as a transnation $27,68,119$

see also Iranian Kurdistan;

Iraqi Kurdistan; Syrian

Kurdistan; Turkish

Kurdistan

Kurdistan National Congress

(KNK) 92, 109, 156

Kurdistan Region of Iraq

(KRI) 12, 67, 76

Kurdistan Regional Government

(KRG) 12, 67, 68,

76,77

Kurdistan Workers' Party (PKK) change from military to political action 92 


\begin{tabular}{|c|c|}
\hline criminalisation of 97,108 , & $\mathbf{M}$ \\
\hline & Macdonald, Sharon \\
\hline French ambivalence towards & Mahmod, Jowan 187 \\
\hline $7,108,154$ & Maison du peuple kurde (Kurdish \\
\hline ISIS fought by $4,71,120,121$ & People's House) 109,156 \\
\hline $\begin{array}{l}\text { joining to escape arranged } \\
\text { marriage } 196\end{array}$ & $\begin{array}{c}\text { Marchand, Laure } 124,125, \\
126,197\end{array}$ \\
\hline $\begin{array}{l}\text { mobilising power of } 149 \\
\text { second generation's attitude to }\end{array}$ & $\begin{array}{l}\text { Marseille } 108,109,115,132, \\
\quad 136,156\end{array}$ \\
\hline $\begin{array}{r}177,189,196 \\
\text { Syria and } 64,68\end{array}$ & McKiernan, Kevin 100 \\
\hline $\begin{array}{l}\text { Turkey and } 12,61,73,97 \\
100,124\end{array}$ & criticism of 186 \\
\hline urds 11,53 & $122,123,138,153,181,202$ \\
\hline $\begin{array}{l}\text { mediatisation } 181 \\
\text { 'non-existence' of } 187 \\
\text { as 'other' } 69\end{array}$ & $\begin{array}{c}\text { Kurdish } 96,98,101,110,158 \\
\text { online activities } 44,96,101,148 \\
179,181,182,186,187,202\end{array}$ \\
\hline $\begin{array}{l}\text { as a transnation } 27,68,119 \\
\text { see also Iranian Kurdistan; }\end{array}$ & $\begin{array}{l}\text { MED-TV } \quad 101 \\
\text { memory } \quad 206,207,209\end{array}$ \\
\hline $\begin{array}{l}\text { Iraqi Kurdistan; Kurdish } \\
\text { diaspora; Kurdish identity; } \\
\text { Kurdistan; Syrian Kurdistan; } \\
\text { Turkish Kurdistan }\end{array}$ & $\begin{array}{l}\text { methodological nationalism } 22 \\
\text { migrant capital } 170,198 \\
\text { migrants' children see second } \\
\text { generation }\end{array}$ \\
\hline Kurmanji dialect $\quad 55,56,96$ & $\begin{array}{l}\text { migration } 81,93,102,118 \\
\text { migration studies } 22,210\end{array}$ \\
\hline $\mathrm{L}$ & Mitterrand, Danielle 94 \\
\hline $\begin{array}{l}\text { labour migrants } 81,84,85,94, \\
102,103,104\end{array}$ & $\begin{array}{l}\text { mobilisation see diaspora } \\
\text { mobilisation }\end{array}$ \\
\hline $\begin{array}{l}\text { language } 55,76 \\
\text { prohibitions on Kurdish } \quad 60,61 \text {, }\end{array}$ & $\begin{array}{l}\text { Mohamed, Sinem } 137 \\
\text { Moss, Dana M. } 40,131,140 \text {, } \\
\quad 142,143,146\end{array}$ \\
\hline $\begin{array}{l}\quad 62,64,72 \\
\text { second generation and } 106,179,\end{array}$ & $\begin{array}{l}\text { mountains, Kurdish affinity } \\
\text { with } 86\end{array}$ \\
\hline $\begin{array}{c}195,207,208 \\
\text { vocabulary of political }\end{array}$ & Müller-Funk, Lea 191, 203 \\
\hline $\begin{array}{c}\text { discourses } 100,151 \\
\text { uage-based population }\end{array}$ & \\
\hline statistics 90 & $\mathbf{N}$ \\
\hline $\begin{array}{l}\text { Lausanne, Treaty of } 59,65 \\
\text { Levitt, Peggy } \quad 194,199 \\
\text { lobbying } 96,129,138,161\end{array}$ & $\begin{array}{l}\text { Natali, Denise } 57 \\
\begin{array}{c}\text { nationalism } 27,60,63,65,69 \\
78,97\end{array}\end{array}$ \\
\hline
\end{tabular}


nation-states $\quad 22,27,69,217$

Nell, Liza 45

networks 148, 170, 197

Newroz celebration $\quad 95,137$

Nezan, Kendal 137

Nordic countries 90, 96, 99, $118,158,172,176,178$

Northern Kurdistan see Turkish Kurdistan

Nuit Debout (Up All Night) protest, Paris 219

\section{O}

O'Toole, Therese 216 Öcalan, Abdullah $\quad 4,62,64,71$ democratic federalism of 71,217

demonstrations for release of $33,95,115,148,200$

online activities $44,96,101,148$, 179, 181, 182, 186, 187, 202 opportunity structures $37,40,145$ Orjuela, Camilla 35 Østergaard-Nielsen, Eva 40, 147 Ottoman empire 58,60

\section{$\mathbf{P}$}

Palani, Joanna 99

Palestinian diaspora $10,203,206$ pan-Kurdish unity $6,122,128$, $163,177,189,203,205$

Pantti, Mervi 139

Paris

as global city 217

Kurdish mobilisation 18,95 , 115, 136, 165

Kurdish participation in Turkish elections 132

Nuit Debout (Up All Night) protest 219
Saturday Mothers event 88 second-generation activities 165 terrorist attacks 109,123 , 154, 169

see also assassination of Kurdish activists in Paris

Passy, Florence 146

Patriotic Revolutionary Youth Movement (YDG-H) 74

Patriotic Union of Kurdistan (PUK) 76, 77

People's Democratic Party (HDP) 74, 75, 132

People's Protection Units

(YPG) 4, 12, 71, 120, 142, 153, 159

see also Women's Protection Units (YPJ)

Persian empire 58

peshmerga (Kurdish military forces, Iraq) $66,68,77$, 99,120

photo exhibitions 143

PKK see Kurdistan Workers' Party political (dis)engagement of second generation 173 , $189,214,216$

political asylum-seekers 81,83 , 85,103

political discourses, language (vocabulary) of 100,151 political opportunity structures $37,40,145$ politics, changing definitions 178 population statistics $89,102,105$ publishing 96 PUK (Patriotic Union of Kurdistan) 76, 77 PYD see Democratic Union Party 
Q

Al Qaeda 109

$\mathbf{R}$

Reception and Integration

Contract, CAI

(Contrat d'accueil et d'intégration) 105

refugees 81, 103, 209

'Rehanna' the angel of

Kobane;Rehana 181

religion 56, 107

Republican People's Party

(CHP) 133

resistance $78,153,185,207$

return migration $45,198,206$

returning combatants 142,159

Rojava see Kobane siege;

Syrian Kurdistan

Rojhelat see Iranian Kurdistan

Roj-TV 98

Romano, David 102

S

Saddam Hussein $\quad 66,86,100$

Safran, William 30, 34

Santelli, Emmanuelle 49

Sarkozy, Nicolas 105

Sassen, Saskia 218

Saturday Mothers

(Cumartesi anneleri) 88

Saylemez, Leyla 124

Scandinavia 90, 96, 99, 118, 158, $172,176,178$

Schiller, Nina Glick 23

Schøtt, Anne-Sofie $28,99,118$, $159,166,168,172,178$

second generation $15,42,163$

apolitical activities preferred 177 citizenship 108

desire to contribute to

Kurdistan 206, 209

diasporic circulation 48

diasporic consciousness 204

differences from first generation $35,43,46,84,168,173$,

191,211

identity and 49, 177

Kobane siege response 163,

$165,202,204,205,213$

mediatisation and 181, 202

mobilising resources 170

political (dis)engagement 173, 189, 214, 216

sense of urgency 167

socialisation into the Kurdish question 199

translocal activities 165, 217

transmitted experience of

displacement 84

transnational participation 15 ,

42, 193, 216

transnational social reality 193

use of term 211

visits and 'return' migration

45, 170, 195, 198

second-generation associations 94

securitisation 97

separatism 68

Sèvres, Treaty of 59, 63, 65

Shain, Yossi 128

social media $44,72,179,181$,

$182,183,191$

Sökefeld, Martin $\quad 32,146,148$,

151,161

Sorani dialect 55,56

South-east Turkey see Turkish

Kurdistan

Southern Kurdistan see Iraqi

Kurdistan 
statelessness $\quad 58,67,88,201$

Strasbourg 33, 95, 200

Sweden 90, 96, 99, 176

Sykes-Picot Agreement 59

Syrian civil war $69,77,99$,

117,138

see also Kobane siege

Syrian Kurdistan (Rojava) 12,

$63,68,69,230$

languages 56, 64

Rojava societal experiment

152, 190, 214

see also Kobane siege

$\mathrm{T}$

Talabani, Jalal $\quad 67,77$

Tamils 28, 43, 44, 203, 208

Tarrow, Sidney 218

Tejel, Jordi 64

television $96,98,101,110$, 121,158

terrorism $62,97,108,153$, 169,185

timeline of events $\mathbf{1 1 6}$

trans-ethnic relations 41

transformative events 78,127

translocal activities $\quad 165,217$

transnational brokerage 35,150 , 151, 153

transnational participation

diaspora mobilisation and 30, 127

electoral activities 131

networks 148

organisational activities 135

political opportunity

structures 147

second generation and 15,42 ,

193, 216

semi-institutional activities

$140,165,168$ transnational social action 218

transnational space $24,34,39$, $89,95,118,194$

transnationalism 24,27

Treaty of Lausanne $\quad 59,65$

Treaty of Sèvres 59, 63, 65

triple murder see assassination of

Kurdish activists in Paris

Turkey

elections 131

establishment by Treaty of Lausanne 59

and the Kurdistan Region of Iraq 76

migration from $83,87,93$, 103, 118

and the Paris

assassinations 124

and the PKK $12,61,73,97,100$

political opportunity

structures 147

political pressure on

Europe $110,123,156,158$

and the Syrian civil war 13 , 69,73

Turkish Kurdistan $12,55,56$, $60,68,73,205,230$

$\mathrm{U}$

UEKF (Union des Étudiants

Kurdes de France, Union

of Kurdish Students in

France) 165

United Kingdom $\quad 65,98,99$,

101, 105, 159

United Nations High

Commissioner for Refugees

(UNHCR) 86

United Nations Human Rights

Office 74

United States 100,185 
unity, pan-Kurdish $\quad 6,122,128$, 163, 177, 189, 203, 205

Uzun, Adem 109, 156

V

Vali, Abbas $\quad 57,78$

Valls, Manuel $\quad 109,154,160$

Van Bruinessen, Martin 56, 80, 97

Van den Bos, Matthijs 45

victimhood discourse 151

Volkan, Vamik D. 35

W

Wahlbeck, Östen $\quad 14,31,47,94$, 103, 104

Weinzimmer, Julianne M. 203, 206

Western Kurdistan see Syrian Kurdistan (Rojava)

Wimmer, Andreas 23

Women's Protection Units (YPJ) 'angel of Kobane' 181 diaspora members joining 99 Elysée meeting with President

Hollande 7, 123, 152, 159
Kobane siege $\quad 4,5,120,122,154$

media focus on $5,71,122$, $153,154,181,186$

Nessrin Abdullah visits

Paris 150, 153

numerical strength 71

PKK affiliation 154

Turkey's cross-border operation against 13

women's rights $153,186,196$

World Kobane Day 122, 149

Y

YDG-H (Patriotic Revolutionary Youth Movement) 74

Yesiltaş, Murat $\quad 182,185,189$

Yezidi Kurds 4, 56, 120

Yildiz, Kerim 57

young people see second generation YPG see People's Protection Units YPJ see Women's Protection Units Yüksekdağ, Figen 75

\section{$\mathbf{Z}$}

Zeydanlığlu, Welat 62 
small Kurdish city located in northern Syria, Kobane, became symbolically significant when ISIS laid siege to the city between September 2014 and January 2015. This pivotal moment in the fight against ISIS threw the international spotlight on the Kurds. The Kobane Generation analyses how Kurdish diaspora communities mobilised in France after the breakout of the Syrian civil war and political unrest in Turkey and Iraq in the 2010s. Tens of thousands of people, mostly but not exclusively diaspora Kurds, demonstrated in major European capitals, expressed their solidarity with Kobane, and engaged in transnational political activism towards Kurdistan.

This seminal book discusses a series of critical events that led to different forms of transnational participation towards Kurdistan. The focus is particularly on how diaspora mobilisations became visible among the second generation, the descendants of Kurdish migrants. The Kobane Generation offers important insights on the generational dynamics of political mobilisations and their significance to understanding diaspora contributions. More broadly, it sheds light on second-generation political activism beyond the diaspora context, analysing it in relation to global transformations in political subjectivities.

Mari Toivanen, PhD, Docent in Sociology, currently works as Academy Research Fellow at the Swedish School of Social Science at the University of Helsinki. She has conducted ethnographic research on a wide range of migration-related topics, focusing on diaspora mobilisation, transnational connections and activities, the second generation, and questions of identity and belonging.

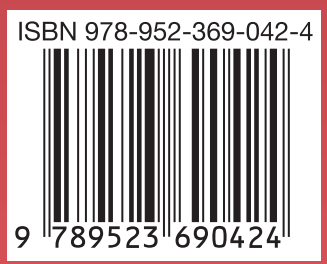

